\title{
Detectie en determinanten van osteoporose in de eerste lijn
}

Citation for published version (APA):

van der Voort, D. (2000). Detectie en determinanten van osteoporose in de eerste lijn. [Doctoral Thesis, Maastricht University]. Universiteit Maastricht. https://doi.org/10.26481/dis.20000628dv

Document status and date:

Published: 01/01/2000

DOI:

$10.26481 /$ dis.20000628dv

Document Version:

Publisher's PDF, also known as Version of record

\section{Please check the document version of this publication:}

- A submitted manuscript is the version of the article upon submission and before peer-review. There can be important differences between the submitted version and the official published version of record.

People interested in the research are advised to contact the author for the final version of the publication, or visit the DOI to the publisher's website.

- The final author version and the galley proof are versions of the publication after peer review.

- The final published version features the final layout of the paper including the volume, issue and page numbers.

Link to publication

\footnotetext{
General rights rights.

- You may freely distribute the URL identifying the publication in the public portal. please follow below link for the End User Agreement:

www.umlib.nl/taverne-license

Take down policy

If you believe that this document breaches copyright please contact us at:

repository@maastrichtuniversity.nl

providing details and we will investigate your claim.
}

Copyright and moral rights for the publications made accessible in the public portal are retained by the authors and/or other copyright owners and it is a condition of accessing publications that users recognise and abide by the legal requirements associated with these

- Users may download and print one copy of any publication from the public portal for the purpose of private study or research.

- You may not further distribute the material or use it for any profit-making activity or commercial gain

If the publication is distributed under the terms of Article $25 \mathrm{fa}$ of the Dutch Copyright Act, indicated by the "Taverne" license above, 
Omslag: Rob Pronk

Foto: Franse vrouwen in Bretagne, Hans Spruijt 
Detectie en determinanten van osteoporose in de eerste lijn

\section{PROEFSCHRIFT}

ter verkrijging van de graad van doctor aan de Universiteit Maastricht, op gezag van de Rector Magnificus, Prof. dr. A.C. Nieuwenhuijzen Kruseman, volgens het besluit van het College van Decanen, in het openbaar te verdedigen op woensdag 28 juni 2000 om 14.00 uur

door

Danny van der Voort 


\section{Promotores}

Prof. dr. G.J. Dinant

Prof dr. P.P. Geusens (LUC, Diepenbeek)

Beoordelingscommissie

Prof. dr. H.F.P. Hillen (voorzitter)

Prof. dr. J. Dequeker (Universiteit Leuven)

Prof dr. J.A. Knottnerus

Prof. dr. T.J,M Verhey (Universiteit Utrecht)

Dr. G.H.I.M. Walenkamp

De uitgave van dit proefschrift werd mogelijk gemaakt door de firma Merck Sharpe \& Dohme B.V. 


\section{VOORWOORD}

Het schrijven van dit proefschrift gebeurde in twee perioden. Bij het bespreken van de studieresultaten, aan het einde van periode 1, kwam de suggestie die resultaten in artikelvorm naar buiten te brengen. Met naar buiten werd bedoeld, dat de wereld net iets groter is dan Nederland en dat de artikelen aan Engelstalige medische tijdschriften zouden moeten kunnen worden aangeboden. Periode 2 was daarmee bepaald. Onwennig werd de publicatieweg ingeslagen met een passieve kennis van de Engelse taal. Nee, niet zonder hulp: mijn promotor was er bij en Van Dale ook.

Hiermee is een belangrijke reden van het schrijven van dit voorwoord aangegeven. Het boekje is tweetalig gebleven. Immers, het bedenken en schrijven van het onderzoeksprotocol, studie design en alles wat daarmee samenhangt gebeurde in het Nederlands en is met name ook bedoeld voor Nederlandse lezers. De studieresultaten echter gingen, in de Engelse taal, de grens over en zo worden ze ook getoond. Het spreekt voor zich dat er ruimschoots is voorzien in Nederlandstalige samenvattingen.

Een voorwoord schrijf je achteraf, een goed moment om de motivatie van destijds nog eens te overwegen. In de beginjaren 90 kwam osteoporose in de belangstelling. Steeds vaker werden patiënt en dokter geconfronteerd met de gevolgen van een sluipende, moeillijk te herkennen, aandoening. Het is niet verwonderlijk dat vanuit de tweede lijn het eerst werd ingegaan op de signalen uit het veld; fracturen belanden nu eenmaal in het ziekenhuis. Vanuit die tweede lijn kwam de uitnodiging om mee te doen aan "informatieavonden over osteoporose voor de leek'. Tijdens die avonden bleek, dat onze kennis (en die van de collegae in de eerste en tweede lijn) over osteoporose tekort schoot. De deelname aan een fase II/III interventiestudie, waarbij van een groot aantal vrouwen de botdichtheid werd gemeten; prikkelde tot de opzet van een onderzoek naar de betekenis van osteoporose voor de huisarts. Met medewerking van collegae en assistentes en ondersteuning door de Capaciteitsgroep Huisartsgeneeskunde van de Universiteit Maastricht werd de uitwoer van het onderzoek mogelijk. Het was een groot onderzoek. De verzamelde data zijn zelfs nu nog niet volledig in kaart gebracht en bevatten, met name voor de sociale kaart van Oostelijk Zuid Limburg, nog een schat aan informatie. Naast de dagelijkse praktijk wetenschappelijk onderzoek doen was vooral interessant en leuk. Het lidmaatschap van de Wetenschappelijke Raad van de Osteoporose Stichting en het fungeren als redactielid van het Nederlands Tijdschrift voor Osteoporose en andere Botziekten waren directe gevolgen.

Het is goed bij aanvang van een dergelijk onderzoek niet te weten wat 'het onderzoeken' inhoudt: wie zou er nog aan beginnen? Aan het einde wan de rit is het anders: nieuwe huisartsonderzoeker begin gewoon, je wordt er nooit minder van. 


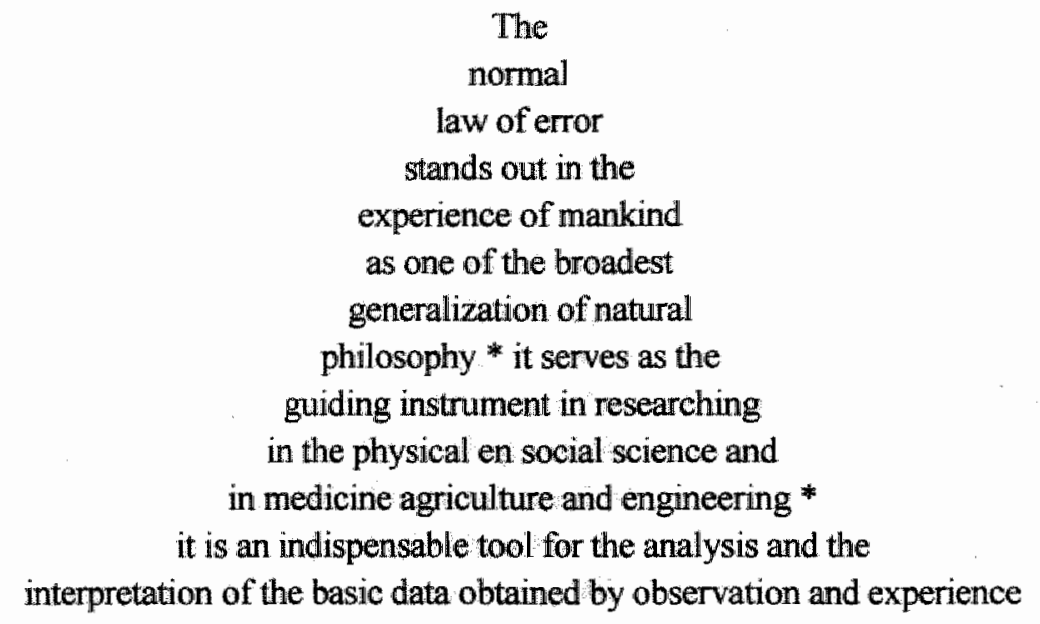

The bell-shaped curve, from chaos, making a new science James Gleick. 


\section{INHOUDSOPGAVE}

1. Inleiding

1.1. Algemene inleiding

1.2 Studie design

1.3 Referenties

$\begin{array}{ll}\text { 2. Resultaten algemeen } & 17\end{array}$

2.1 Pilotstudie 17

$\begin{array}{ll}2.2 & \text { Compliance, oproep en respons } \\ 2.37\end{array}$

2.3 Beschrijving onderzoekspopulatie $\quad 20$

2.4 Samenvatting 26

3. Construction of an algorithm for quick detection of patients with low bone mineral density and its applicability in daily general practice. $\quad 27$

3.1 Samenvatting

4. Screening for osteoporosis using easily obtainable biometrical data: diagnostic accuracy of measured, self-reported and recalled BMI, and related costs of bone mineral density measurements.

4.1 Samenvatting

5. How to use co-morbidity for detecting osteoporosis in daily general practice.

$\begin{array}{lll}5.1 & \text { Samenvatting } & 79\end{array}$

6. Risk factors for osteoporosis in relation to fractures 81

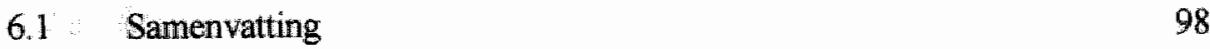

7. Aging and social and socio-economic determinants of osteoporosis, studied in healthy postmenopausal women.

7.1 Samenvalting

8. Beschouwing

9. Samenvatting

9.1 Summary 
Dankwwoord

Curriculium vitae

Appendix A

Appendix B

Appendix C

Appendix D

Appendix $\mathrm{E}$

165

Appendix $\mathrm{F}$ 


\section{Hoofdstuk 1}

\section{Inleiding}

\subsection{Algemene inleiding}

The Persian war.

The skulls of the Persians are so soft that if you care only to throw a pebble at one, you will make a hole in it; while those of the Egyptians are so hard that you can scarcely break one if you struck it with a stone. The reason which they gave me...

Herodotus, de geschiedschrijver, in circa 450 voor Chr. beschrijft aldus, dat er verschillen zijn tussen de rassen voor wat betreft de botsterkte van de schedels Hij wijst op de breekbaarheid van 'zacht' bot ${ }^{(1)}$.

Botsterkte en breekbaarheid staan in relatie tot de mate van het broos zijn van bot. Anatomisch, macroscopisch, gezien is elk bot in zekere mate broos, er is daarbij geen scherpe overgang zichtbaar tussen normaal broos bot en abnormaal broos bot. Histologisch en microscopisch blijkt dat de mate van broos zijn samenhangt met de aanwezige hoeveelheid steunmateriaal. Pommer beschreef in 1885 de verschillen tussen osteomalacie en te broos, maar normaal bot. Hij reserveerde de term osteoporose voor te broos bot ${ }^{(2)}$.

Osteoporose is dus geen nieuwe term, noch een nieuwe ziekte leert de geschreven geschiedenis. Met moderne onderzoeksmethoden werd recent aangetoond dat er ook verder terug in de tijd grote verschillen aanwezig waren in de botdichtheid van mensen ${ }^{(3)}$. Osteoporose goed definiëren bleek niet eenvoudig, begrijpelijk gezien de niet scherpe overgang tussen normaal en abnormaal broos bot. Pas in 1993 werd de, thans meest gebruikte, definitie vastgesteld tijdens een 'WHO-consensus conferentije ${ }^{(4,5)}$ :

"A disease characterised by low bone mass and microarchitectural deterioration of bone tissue, leading to enhanced bone fragility and a consequent increase in fracture risk:"

Naast deze kwalitatieve definitie staat de meer kwantitatieve of operationele definitie. De botmassa wordt daarin weergegeven als bot-mineraal-dichtheid (BMD) of bot-mineraal concentratie(BMC). Het bepalen van de BMD werd tot eind jaren 80 gedaan met behulp van verschillende instrumenten. De validiteit, de snelheid en het gebruiksgemak van de gebruikte methoden waren niet altijd optimaal. Met de intrede van de computergestuurde dual energy X-ray absorptiometry (DEXA, meestal afgekort tot DXA) kwam er eind jaren 80 een methode beschikbaar, waarmee de BMD snel, precies en met een goede re- 
produceerbaarheid kon worden gemeten ${ }^{(6,7)}$. De DEXA-uitslag werd de 'gouden standaard' voor de BMD.

Geformuleerd in standaarddeviaties (SD) wan normaal werden vier diagnostische categorieèn vastgesteld:

Normal: a value for BMD or bone mineral content (BMC) within 1 SD of the young adult reference mean.

Low bone mass (osteopenia) a value for $\mathrm{BMD}$ or $\mathrm{BMC}$ more than $1 \mathrm{SD}$ below the young adult mean but less than 2,5 SD below this value.

Osteoporosis: a value for $\mathrm{BMD}$ or $\mathrm{BMC} 2,5 \mathrm{SD}$ or more below the young adult mean.

Severe osteoporosis: a value for $\mathrm{BMD}$ or BMC 2,5 SD or more below the young adult mean in the presence of one or more fragility fractures ${ }^{(\zeta)}$.

De 'young adult reference mean' in deze definitie is de T-score of peak bone mass (PBM). De waarde die wordt aangeduid als osteopenie (van -1 tot $-2,5$ SD) is geen praktische term, omdat de letterlijke vertaling van osteopenie (penia $=$ Grieks voor te kort) ook de waarde inhoudt die meer is dan 2,5 SD onder normaal.

De prevalentie van osteoporose en de incidentie van osteoporotische fracturen vertonen een stijgende tendens. Met name in de westerse, geindustrialiseerde wereld neemt het aantal heupfracturen al jaren sterk toe ${ }^{(8-12)}$. Twee factoren worden daarvoor als oorzaak aangeduid: de vergrijzing van de bevolking als zekere en de veranderde leefstijl als waarschijnlijke oorzaak. De fractuurkans is daarbij afhankelijk van zowel leeftijdsgebonden factoren als verhoogde valkans door bijvoorbeeld verminderde coördinatie en toegenomen co-morbiditeit, als van de kwaliteit van het bot, de BMD. In welke mate de leeftijdsgecorrigeerde BMD wordt beînvloed door veranderende leefstijlfactoren kan slechts op termijn worden berekend aangezien de accurate BMD meting van relatief recente datum 1s.

De oorzaak van osteoporose is niet eenduidig, getuige de talloze suggesties die in de literatuur worden genoemd (oriênterend literatuur onderzoek leverde meer dan 90 determinanten op van osteoporose en osteoporotische fracturen $)^{(13.50)}$. Die suggesties waren overigens gevolgtrekkingen uit studies die doorgaans in een 'klinische setting' werden verricht, waardoor de bevindingen niet zonder meer kunnen worden geëxtrapoleerd naar de doorsnee bevolking, zeg maar naar de dagelijkse huisartspraktijk. Vermeende oorzaken en dus een niet volledig opgehelderde pathogenese verhinderen de snelle ontwikkeling van - en het handhaven van - een optimaal preventief en therapeutisch beleid. De toenemende fracturincidentie gaat gepaard met een forse toename van de kosten in de gezondheidszorg. Alleen al de heupfracturen vormen in Nederland een jaarlijkse last van een half miljard gulden. Dat klinkt indrukwekkend maar geeft geen indruk van het menselijk leed dat de ziekte met zich mee brengt. Het langdurig niet meer kunnen func- 
tioneren, de vaak blijvende handicaps en de kans aan de heupfractuur of aan de gevolgen daarvan te zullen overlijden, zijn zaken die niet in geld zijn uit te drukken.

Osteoporose en heupfracturen worden in een adem genoemd; de relatie daartussen is bekend. De relaties tussen osteoporose en andere fracturen, het kleiner en krommer worden, osteoporose en klachten staan wat op de achtergrond. Het zijn echter oorzaken van een belangrijke achteruitgang van de kwaliteit van het leven van de ouder wordende mens. In onze maatschappij is dat op de eerste plaats de vrouw; zij wordt 6-7 jaar ouder dan de man. De kwaliteit van leven is in die extra jaren voor veel vrouwen niet optimaal. Sommigen drukken dit tegenwoordig anders uit: de vrouw wordt niet ouder maar sterft langzamer.

Een drietal Nederlandse wetenschappelijke organisaties heeft zich recent gebogen over de problemen rondom de diagnostiek en preventie van osteoporose en osteoporotische fracturen. Begin 1998 verscheen het rapport van de Gezondheidsraad ${ }^{(51)}$. De aanbevelingen werden positief ontvangen en binnen een jaar behoorde dit rapport tot de top 10 van de meest opgevraagde publicaties van de Gezondheidsraad sinds 1995. Een jaar later, maart 1999 publiceerde het Nederlands Huisartsgenootschap (NHG) haar Standaard Osteoporose voor de huisarts ${ }^{(\mathbf{S 2})}$. Deze standaard was aanleiding tot heel wat discussies. De standaardencommissie was van mening dat een deel van de aambevelingen, gegeven door de Gezondheidsraad Commissie, door de Nederlandse huisartsen niet zonder meer zouden moeten worden opgevolgd. De derde organisatie is het Centraal Begeleidingsorgaan (CBO); de verslaglegging wordt medio 2000 verwacht. De verschillende commissies in een klein land als Nederland komen nog niet tot gelijkluidende conclusies en adviezen en ook wereldwijd zijn er tal van controverses aangaande diagnostiek en preventie van osteoporose. Sinds 1990 werden tientallen consensus gepubliceerd (de meest bekende, meest frequent geciteerde, consensus zijn in de literatuurlijst opgenomen ${ }^{(53-68)}$ ). De benadering van de problematiek rondom osteoporose verschilt per onderzoekersgroep en dus per consensus. Het verschil in benadering en aanpak van osteoporose hangt mogelijk samen met de verschillen tussen de gezondheidszorgstructuren en met de verschillende politieke verhoudingen in de diverse landen. Er is tot op heden nog niet voldaan aan de verwachting dat in landen met een vergelijkbare gezondheidszorgstructuur (zoals Nederland, Groot-Brittannië, Canada en Scandinavië) deskundige adviescommissies tot een gelijkluidend advies aan de medische beroepsgroepen zullen komen. De huisarts zal in zijn/haar handelen gebruik willen maken van de door de beroepsgroep opgestelde richtlijnen en zal door de patiênt daar ook op aangesproken moeten kunnen worden. De, op basis van 'evidence based medicine" ter beschikking staande NHG Standaard Osteoporose spoort nog niet met de visie van de tegenwoordige patiënt. Die patiënt is steeds beter geinformeerd. Het is de 
vraag hoe die patient, die met van het internet gehaalde informatie in de hand, de huisarts consulteert; op één lijn komt met de op 'evidence' gebaseerde zorg ${ }^{(69)}$.

Diagnostiek gaat vooraf aan zorg en met betrekking tot osteoporose is het van groot belang dat de huisarts beschikt over een diagnostisch instrument van hoge kwaliteit. Het in de populatie opsporen van een osteoporotische patient met cen nog geringe mate van expressie van de ziekte is een lastig karwei ${ }^{(70)}$. Het betreft immers een aandoening die vooral voorkomt op latere leeftijd en frequent gepaard gaat met co-morbiditeit en de daaraan gerelateerde klachten.

Dit proefschrift beschrijft het voorkomen van osteoporose onder postmenopauzale vrouwen en de prevalentie van osteoporose in de dagelijkse huisartspraktijk. Het gaat in op de diagnostische betekenis van risicofactoren voor osteoporose en osteoporotische fracturen (waaronder biometrische en lifestyle factoren). Het gaat in op de relatie tussen osteoporose en klachten, en die tussen osteoporose en co-morbiditeit. Ook worden de diagnostische kosten, het aantal BMD-metingen nodig om een osteoporotische patiênte in de populatie te detecteren, besproken. Van de determinanten van osteoporose wordt nagegaan wat hun relatie is met het gevolg van osteoporose: de fractuur.

Ook sociaal-maatschappelijke aspecten worden besproken: het al of niet hebben van kinderen, het al of niet bekend zijn met ziekte(n), de fysieke belasting van werk, de intellectuele kwaliteiten passend bij (of noodzakelijk voor) dat werk en het al of niet beoefenen van rugbelastende sportieve activiteiten. Deze aspecten worden in verband gebracht met de BMD.

\section{Vraagstellingen}

1. Wat is de prevalentie van osteoporose onder de postmenopauzale vrouwen van 50 tot 80 jaar in de normpraktijk van de huisarts?

2. Wat is de relatie tussen aan osteoporose gerelateerde klachten, verschijnselen (fracturen, symptomen, biometrie en klinische bevindingen) enerzijds en het wel of niet aanwezig zijn van de aandoening anderzijds?

3. Welk diagnostisch advies (inclusief gerelateerde kosten) kan, op grond van de uitkomsten bij vraag 1 en 2 , voor de dagelijkse huisartspraktijk worden opgesteld? 
Hoofdstuk 1.2 behandelt het design en de operationalisering van de studie.

Hoofdstuk 2 beschrijft de algemene resultaten; de kenmerken van de onderzoekspopulatie. De pilotstudie in de eerste maand van het onderzoek, de compliance en de beschrijving van de onderzoekspopulatie staan centraal.

Hoofdstuk 3 is het kernhoofdstuk van het onderzoek en vormt de basis van de overige hoofdstukken.

De prevalentie van osteoporose en osteopenie werd bepaald en wan een groot aantal variabelen werd berekend wat de associatie is met de aanwezigheid van osteoporose. Het doel was een algoritme te maken op grond waarvan de huisarts in de dagelijkse praktijk zo snel en eenvoudig mogelijk osteoporotische patiënten kan opsporen.

Hoofdstuk 4 omschrijft hoe subjectieve gegevens, zoals het door de patient herinnerde gewicht op 25-30 jarige leeftijd en hun lengte, gebruikt kunnen worden om de populatie - kostenbesparend - in te delen in subgroepen, die wel of niet in aanmerking komen voor screening op de aanwezigheid van osteoporose.

Hoofdstuk 5 handelt over de relatie tussen co-morbiditeit en osteoporose Er wordt beschreven in welke mate co-morbiditeit kan worden gebruikt om osteoporose op het spoor te komen. De betekenis voor de huisarts wordt bepaald door de relatie te beschrijven tussen osteoporose en die aandoeningen, waarvan met $95 \%$ zekerheid kan worden gezegd dat er ten minste één betreffende patiënt aanwezig is in een normatieve huisartspraktijk.

Hoofdstuk 6 laat zien hoe de in hoofdstuk 3 genoemde risicofactoren voor osteoporose zich gedragen als risicofactoren voor het ontstaan van fracturen. De analyses werden twee maal uitgevoerd: voor de totale studie populatie en voor een subgroep waarvan het vroegere gewicht bekend was. De geschatte body mass index (BMI) op jonge leeftijd werd in de analyse betrokken.

Hoofdstuk 7 beschrijft de relatie tussen sociale en sociaal-economische gegevens en het voorkomen van osteoporose. Bekeken worden onder andere het beroep en de beroepsgebonden lichamelijke inspanning, sportieve activiteiten en het hebben van kinderen. 
Hoofdstuk 8 is de beschouwing.

In de algemene discussie wordt kritisch gekeken naar de beantwoording van de vraagstellingen, de problemen die zich hier en daar tijdens de studie voordeden en de nieuwe vragen die door de studie werden opgeworpen.

Ingegaan wordt op het fenomeen dat er talloze oorzaken van osteoporose worden gevonden.

\subsection{Studie design}

\section{Algemeen}

Het onderzoek is een cross-sectionele, population-based studie onder postmenopauzale (niet negroìde) vrouwen van $50-80$ jaar.

De relatie werd onderzocht tussen diverse gegevens enerzijds en het al of niet voorkomen van osteoporose of lage BMD anderzijds. Deze gegevens betreffen de aanen afwezigheid van ziekten, klachten, het gebruik van medicatie, gegevens uit de familie anamnese, lifestyle factoren, voedingsgewoontes en biometrische gegevens. Daarmee werd bepaald in welke mate, door de huisarts op eenvoudige wijze te verkrijgen gegevens, die potentieel aan osteoporose zijn gerelateerd, kunnen onderscheiden tussen het wel of niet aanwezig zijn van osteoporose of een lage BMD .

In de regio Oostelijk Zuid-Limburg werd, in de periode van oktober 1992 tot en met maart 1995, van 4725 vrouwen de botdichtheid van de lumbale wervelkolom (L2-4) gemeten. Eveneens werden in dezelfde zitting een uitgebreide enquêtte afgenomen en een aantal biometrische bepalingen verricht.

Alle metingen werden verricht door vier getrainde onderzoeksassistenten en vonden plaats in de praktijk van de onderzoeker (het onderzoekscentrum). 23 deelnemende huisartsen selecteerden uit hun patiêntenbestanden alle vrouwen van 50 tot 80 jaar $(n=9107)$. Vervolgens screenden de huisartsen deze vrouwen op in- en exclusiecriteria (zie appendix A). Deze criteria werden gebruikt ter detectie van vrouwen met aandoeningen of ziekten waarvan wordt aangenomen dat die het botmetabolisme kunnen beïnvloeden. Alle vrouwen die voldeden aan de inclusiecriteria $(n=5303)$ en een steekproef van $25 \%(943)$ van de overige vrouwen $(n=3804)$, ontvingen een brief met uitleg over het onderzoek en een verzoek om deelname (zie ook het stroomdiagram op pagina 12). De praktijkassistenten van de huisartsen regelden de afspraken voor de BMD-meting. Het onderzoek liep parallel aan de therapeutische trial van de firma Sanofi. Parallel wil hier zeggen, dat voor onze studie gebruik werd gemaakt van de tijd die tussen de metingen en tijdens de metingen beschikbaar was. De participatie aan de therapeutische trial vereiste het hanteren van de genoemde 
exclusiecriteria. Ter voorkoming van selectiebias en om vergelijking tussen geìncludeerden en geëxcludeerden mogelijk te maken werd de steekproef, als hierboven genoemd, toegevoegd.

\section{Patiēnten}

\section{Identificatie van de patiënten}

Het samenstellen van de lijst van deelneemsters werd als volgt georganiseerd. De huisartsdeelnemer en zijn praktijkassistente maakten een lijst van alle 50 tot 80 jarige in de praktijk ingeschreven vrouwelijke patiënten. In de geautomatiseerde praktijken kon de gevraagde lijst eenvoudig worden aangeleverd. In de niet geautomatiseerde praktijken kon met behulp van de beschikbare lijsten van ziekenfonds- en particulierverzekerden en zonodig met gegevens uit 'de kaartenbak', de gevraagde lijst worden samengesteld. Op deze lijsten gaven de huisartsen aan welke patiënten voldeden aan de inclusiecriteria (zie appendix A).

De zo verkregen overzichten werden aan de onderzoeker ter beschikking gesteld.

\section{Steekproef uit de groep geëxcludeerden}

De steekproef uit de, door de huisartsen, geëxcludeerde patiënten werd als volgt getrokken. De research nurses plaatsten de door de huisarts aangemerkte geëxcludeerde patiënten in alfabetische volgorde om selectiebias op grond van geboortedata te vermijden. Vervolgens werd uit deze lijst elke vierde patiènte uitgenodigd voor deelname aan de studie. Indien een patiènte was overleden of wegens invaliditeit of ziekte niet naar het onderzoekscentrum kon komen, werd de volgende of zonodig de vorige patiènte van de lijst benaderd. Indien een patiënte niet wenste deel te nemen werd de volgende 'vierde patiënte' benaderd. Om logistieke redenen, met name het vervoer van de patiënten naar en van het onderzoekscentrum, werden de patienten uit de steekproef opgeroepen nadat de metingen van alle oorspronkelijk geïncludeerde patiènten waren afgerond.

\section{Grootte van de onderzoekspopulatie}

Bij aanvang van de studie was niet bekend hoe groot de prevalentie van osteoporose zou zijn onder postmenopauzale vrouwen tussen de 50 en 80 jaar. Het maximaal haalbare aantal te onderzoeken geincludeerde vrouwen, werd bepaald door het tijdstip waarop de inclusieperiode van de therapeutische trial eindigde. Op het moment dat de oproep van de steekproef van de geëxcludeerden een aanvang nam, was van circa 4000 vrouwen de BMD gemeten. Op grond van literatuurgegevens werd de prevalentie van osteoporose onder de postmenopauzale vrouwen geschat op $20 \%{ }^{(8-12)}$. Het aantal te onderzoeken variabelen was bij aanvang van het onderzoek geschat op 65 . Het aantal te onderzoeken geëxcludeerden werd vervolgens bepaald door de vuistregel, dat voor een betrouwbare 
statische verwerking tenminste tien pateenten per te onderzoeken variabele in het bestand aanwezig moeten zijn. We besloten $25 \%$ van de geéxcludeerden op te roepen

\section{Informed consent}

Alle vrouwen die werden opgenomen in de studie gaven hun informed consent.

\section{Metingen van de BMD}

Betrouwbaarheid en reproduceerbaarheid van de BMD-metingen.

Alle BMD-metingen werden met hetzelfde apparaat verricht (Hologic QDR 1000). Elke ochtend vond de standaard ijking plaats (kalibrering met altijd hetzelfde standaardfantoom): Indien er zich afwijkingen voordeden tijdens de kalibrering, werden de BMDmetingen opgeschort, totdat de apparatuur door technici van de fabrikant was bijgesteld. De precisie van de BMD-metingen van de lumbale wervelkolom, uitgedrukt als variatiecoefflicient ligt tussen $0,5 \%$ en $1,0 \%$.

Kruiskalibrering vond plaats met DEXA-apparatuur in binnen- en buitenland met behulp van een en hetzelfde fantoom binnen een tijdsbestek van enkele dagen. Een recent onderzoek van 62 DEXA-meters toonde aan dat de BMD-waarden, gemeten met apparaten van dezelfde fabrikant, zeer goed vergelijkbaar zijn ${ }^{(6-8,71)}$. Ter controle van de reproduceerbaarheid van de BMD-metingen werden tijdens de pilotstudie alle meetresultaten mede beoordeeld door een onafhankelijke externe deskundige. De reproduceerbaarheidsfout wordt geschat op $1-2 \%{ }^{(72)}$.

\section{Stroomdiagram}

Onderstaand stroomdiagram (flow chart) toont hoe de selectie van de deelneemsters tot stand kwam en van hoeveel patiènten de verzamelde data konden worden geanalyseerd.

\begin{tabular}{|l|c|c|c|}
\hline & $100 \%$ & \multicolumn{2}{|c|}{$\begin{array}{c}9107 \text { women aged 50-80 years } \\
\text { identified in 12 general practice centers. }\end{array}$} \\
\hline Identified by 23 GPs & & $\begin{array}{c}5303 \\
\text { postmenopausal } \\
\text { healthy women }\end{array}$ & $\begin{array}{c}3804 \\
\text { not-healthy women }\end{array}$ \\
\hline Selected for participation & $69 \%$ & 5303 & 943 (25\% of 3804) \\
\hline Invited & $69 \%$ & \multicolumn{3}{|c|}{6246} \\
\hline Participated (76\% of 6246) & $52 \%$ & 4725 \\
\hline Informed consent obtained & & 4725 \\
\hline First four weeks, pilot study & & \multicolumn{3}{|c|}{-516} \\
\hline DEXA measurement failed & & \multicolumn{3}{|c|}{-6} \\
\hline Used for statistical analysis & $46 \%$ & 3500 & \multicolumn{3}{|c|}{403} \\
\hline
\end{tabular}


In appendix B wordt beschreven hoeveel medewerkers bij het onderzoek waren betrokken en hoe de diverse procedures verliepen (oproep patiënten, metingen en datamanagement)

\subsection{REFERENTTES}

1. Herodotus. The Persian war book III. In Thompson J, Hayes BJ, editors The University Tutorial Series: London: University college Press.

2. Pommer G. Untersuchungen uber Osteomallacie und rachitis nebst Beitragen zur Kenntniss der Knochenresoption und apposition in verschiedene Altersperioden und der durchbohrenden Gefasse. Leipzig: FCW Vogel, 1985.

3. Frigo P, Lang C. Osteoporosis in a woman of the bronze age. N Engl J Med 1995:1468.

4. Consensus development conference: diagnosis, prophylaxis and treatment of osteoporosis. American journal of medicine1991;90:107-110.

5. Assesment of fracture risk and its application to screening for postmenopausal osteoporosis. Geneva: WHO Technical report series, 843, 1994.

6. Slosman D, Rizoll R, Dansth A, Bonjour JP. Bone Mineral Density of Lumbar Vertebral Body Determined in Supine and Lateral Decubitus. Study of Precision and Sensitivity. I Bone Mine Res 1992;7(suppll)s192

7. Kuyk C van, Genant HK, Schitte HE, Botdensitometrie en osteoporose. Ned Tijdschr Geneesk (1992); 136, (25): 1193-7

8. Genant HK Current assesment of osteoporosis: proceedings of an international symposium. Eur $J$ Radiol 1995;20(3):163-4.

9. Cummings SR, Kelsey $\pi$, Nevitt MC,ODowd KJ. Epidemiology of osteoporosis and osteoporotic fractures. Epidemiologic Reviews (1985);7:178-209.

10. FTJ Boereboom, RRM de Groot, JA Raymakers, SA Duursma. The incidence of hip fractures in The Netherlands. Neth J Med 1991;38:51-8.

11. Melton LJ, Kan SH, Frye MA, OFallon WM, Riggs BL. Epidemiology of wertebral fractures in women. Am J Epid 1989;129 1000-11.

12. Riggs BL, Melton $\mathrm{LJ}$. The worldwide problem of osteoporosis: Insights afforded by epidemiology. Bone $1995 ; 17 ; 505 \mathrm{~s}-511 \mathrm{~s}$.

13. Aloia JF, Cohn SH, Vaswani A, Yen JK, Yuen K, Ellis K. Risk factors for postmenopausal osteoporosis. Am J Med 1985;78:95-100.

14. Bawer DC, Browner WS, Cauley JA, Orwoll ES, Scott JC, Black DM al Factors associated with appendicular bone mass in older women. Ann Intern Med 1993;118:657-65.

15. Compston JE, Cooper $C_{y}$ Kanis JA. Bone densitometry in clinical practice. BMJ 1995;310:1507-10.

16. Compston JE. risk factors for osteoporosis. Clin Endocrinol 1992;36:223-4.

17. Cooper $C$, Shah $S_{y}$ Hand DJ, Adams J, Compston J, Davie $\mathrm{M}_{*}$ et al. Sereening for vertebral osteoporosis using individual risk factors. Osteoporosis Int 1991;2:48-53.

18. Cummings $S$. Risk factors for hip fracture in white wornen. N Engl J Med 1995;332:767-772. 
19. Cummings SR, Kelsey J, Nevitt MC; ODowA KJ. Epidemiology of osteoporosis and osteoporotic fractures. Epidemiologic reviews 1985;7:178-208.

20. Cummings SR, Newitt MC, Browner WS, Stone H, Fox K, Ensrud KE, et al. Risk factors for hip fracture in white women. N Engl I Med 1995;332:767-73.

21. Elliot JR., Ayling E, Gilchinist NL, Tumer J, Wells JE, Sainsbury R. Historical assessment of risk factors in screening for osteopenia in normal Caucasian popalation. Aust NZ J Med 1993;23:45862.

22. Elders PJM, Netelenbos JC, Lips P, Khoe E, Van Ginkel; FC, Hulshof KFAM et al. Perimenopausal bone mass arad risk factors. Bone and Mineral 1989;7:289-99.

23. Genant HK. Radiology of osteoporosis. in Riggs BL, Melton LJ: Osteoporosis: pathogenesis, diagnosis and etiology. New York: Raven Press, 1992

24. Hanssen Ma, Overgaard K, Riis BJ, Cristiansen C. Potential risk factors for development of postmenopausal osteoporosis, examined over a 12-year period. Osteoporosis Int 1991;1:95-102.

25. Heaney R.P. Bone mass, nutrition, and other lifestyle factors. Am J Med 1993;95(suppl 5A):29s-33s.

26. Hemert AM van, Vandenbroucke JP, Birkenbäger $\mathrm{C}$, Valkenburg HA. Predicting of osteoporotic fractures in the general population by a fracture risk score. Am J Epidemiol 1990;132:123-135.

27. Johnson BE, Lucasey B, Robinson RG, Lukert BP. Contributing Diagmosis in Osteoporosis. The value of complete medical evaluation. Arch Intern Med 1989;149:1069-71.

28. Johnston $\mathrm{CC}$, Slemenda $\mathrm{CW}$. Risk assessment: Theoretical considerations. Am J Med $1993 ; 95$, (suppl 5A),2s-5s.

29. Khosla S, Melton LJ III Secondary Osteoporosis. In. Osteoporosis: Etiology, Diagnosis, and Management. Riggs BL, Melton LJ III. New York: Rawen Press, 1988:111-31

30. Kleerekoper M. Factors commonly associated with osteopenia and/or osteoporotic syndromes. In: Favus MJ. Primer on metabolic bone diseases and disorders of mineral metabolism. New York: Raven Press, 1996.

31. Krall EA, Dawson-Hughes B. Heritable and lifestyle determinants of bone mineral density. J Bone Miner Res 1993;8:1-9.

32. Lauritzen $\mathrm{S}$, Menair $\mathbb{P}$, Lund $\mathbb{B}$. risk factors for hip fracture. A review. Danish Med Bull $1993,40: 479,485$.

33. Mcknight A, Steele K, Millis K, Gilchrist $C$, Taggart H. Body mimeral density in relation to medical and lifestyle risk factors for osteoporosis in pre-memopansal, menopausal an post-menopausal women in general practice. Br J Gen Pract 1995;45:317-20.

34. Melton LJ, Eddy DM, Johnston CC. Screening for osteoporosis. Ann Int Med 1990;112:516-528.

35. Melton LI, Kan SH, Waluner LW, Riggs BL. Lifetime fracture risk: an approach to hip fracture risk asserssment based on bone mineral density and age. J. Clin. Epidemiol, 1988, 41: 985-994.

36. Melton LJ, Chas EYS, Lane J. Biomechanical aspects of fractures. In:Riggs BL, Melton LJ, editors. Osteoponosis: etiology, diagnosis, and management. New York:Raven Press, 1988:111-31.

37. Ooms ME, Lips $P$, Lingen $A$ van, Valkenburg HA. Determinants of bone mineral density and risk factors for osteoporosis in heal thy elderly women. J Bone Miner Res 1993;8:669-675

38. Orwoll ES, Bauer DC, Vogt TM, Fox KM. Axial bone mass in older women. Ann Intern Med $1996 ; 124: 187-196$. 
39. Raisz LG. Secondary osteoporosis. In: Osteoporosis 1996. Proceedings of the 1996 World Congress on Osteoporosis. Papapoulos SE, Lips $\mathrm{P}_{\text {n }}$ Pols HAP, Johnston CC, Delmas PD, Editors. Amsterdam: Elsevier Science B. V., 1996; 339-399.

40. Reid DM, Harvie J. Secundary osteoporosis. In: Ballièri's Clinical Endocrinology and Metabolism $1997 ; 83-95$

41. Reid IR, Ames $R$, Evans MC, Sharpe $S$, France JT, Gamble G. effect of calcium supplementation on bone loss in postmenopausal women. n Engl I Med 1993;328:460-4

42. Reid IR, Chin K, Evans M Jones JG. Relation between increase in length of hip axis in older women between 1950s and 1990s and increase in age specific rates of hip fiacture. BMJ $1994 ; 309: 508-9$

43. Ribot $C_{y}$ Tremollieres $F$, Pouilles JM. Can we detect women with low bone mass using elinical risk factors? Am J Med 1995;98(2A):52S-55S.

44. Ribot C, Pouilles JM, Bonnen M, Tremollieres F. assessment of the risk of postmenopausal osteoporosis using clinical factors. Clin Endocrinology 1992;36:225-228.

45. Riggs BL, Melton LJ. Involutional osteoporosis. N Engl J Med 1986;314:1676-86.

46. Rosen CJ. Endocrime disorders and osteoporosis. Current opinion in Rheumatology 1997;9:355-61

47. Ross PD. Osteoporosis. Frequency, consequences and risk factors. Arch Intern Med 1996;156:1399. 411.

48. Shane E. Osteoporosis associated with illness and medications. In: Marcus R, Feldman D, Kelsey J. Osteoporosis: San Diego: Academic Press, 1996;925-946

49. Slemenda $\mathrm{CW}$, Christian JC, Williams $\mathrm{CJ}$, Norton JA, Johnston $\mathrm{CC}_{\text {, }}$ Genetic determinants of bone mass in adult women: a re-evaluation of the twin model and the potential importance of gene interaction on heritabillity estimates. J Bone miner Res $1991 ; 6: 561-567$.

50. Stevenson JC, Lees B, Devenport M, Cust MP, Ganger KF. Determinants of bone density in normal women: risk factors for future osteoporosis? $\mathrm{Br}$ Med J 1989;298:924-28.

51. Gezondheidsraad: Commissie osteoporose. Preventie van an osteoporose gerelateerde fracturen. Rijswijk:Gezondheidsraad, 1998; No 1998/05.

52. Elders P, Keimpema JC, Petri H, Matser A, Pigmans V, Bolhuis A et al. NHG-standaard Osteoporose. Huisarts en wetenschap 1999;42:115-28.

53. Andersson GBJ, Bostrom MPG, Eyre DR, Glasser DL, Hu SS, Lane MJ, et all Consensus summary on the diagnosis and treament of osteoporosis. Spine 1997,22:63s-65s.

54. Anonymous. Clinical practice guidelines for the diagnosis and management of osteoporosis. Can Med Assoc J 1996;155:1113-33.

55. Anonymous. Osteoporosis: a decision-malking document for diagnosis and prevention. National osteoporosis society, 1994.

56. Anonymous. Osteoporosis.review of the evidence for prevention, diagnosisand tratment and costeffectiveness analysis. Osteoporosis lnt 1998;8(suppl 4):s1-s6.

57. Anonymous. Guidelines for the early detection of osteoporosis and prediction of fracture nisk. SAMJ $1996 ; 86: 1113-6$.

58. Anonymus. Consensus development conference: diagnosis, prophyllaxis, and treatment of osteoporosis. Am J Med 1993;94:646-50. 
59. Anonymous. Consensus report Osteoporosis. Report from a medical consensus conference 9-11 January 1995, Copenhagen.

60. Consensus development statement. Who are candidates for prevention and treatment of osteoporosis? Osteoporosis Int 1997;71-6.

61. Daly PA. Office management of osteoporosis: a guide for the primary care provider. Comprehensive therapy $1995 ; 21(10): 565-74$.

62. Eastell $\mathrm{R}$, Boyle IT, Compston $\mathrm{J}$, Cooper $\mathrm{C}$, Fogelman $\mathrm{L}$, Francis $\mathrm{RM}$, et al. Management of male osteoporosis: report of the UK consensus group. Q J Med 1998;91:71-92.

63. Frost HM. Changing views about osteoporosis. Osteoporosis Int 1999;10:345-352

64. Miller PD, Bonnick SL, Rosen CI. Consensus of an international panel on the clinical utility of bone mass measurements in the detection of low bone mass in the adult population. Calcif Tissue Int 1996;58:207-14.

65. Kaufman IM, Devogelaer JP, Raeman F, Rozenberg $S$, Body JJ, Westhovens $\mathbb{R}$, Reginster JY. Prevention and treatument of postmenopausal osteoporosis National Consensus of the "Belgian Bone Club", November 1996. Clinical-Rheumatology. 1997; 16 (4) 343-345.

66. Reid IR. Osteoporosis - emerging consensus. Aust NZ J Med 1997;27:643-7.

67. Scott PI: Consensus viewpoint on the treatment of postmenopausal osteoporosis. NZ Med J 1997;110:397-9.

68. The Royal College of Physicians. Osteoporosis, Clinical guidelines for prevention and treatment. Suffolk: The Lavenham Press, 1999.

69. Mazel JA, Flikweert S. Huisarts: acrobaat of lokettist?. Ned Tijdschr Geneesk 1999;143(48):2401-3.

70. Knottnerus JA Diagnostic prediction rules: principles, requirements, and pitfals. Med Decis Making 1995;22 (2):341-63.

71. Kolta $S$, Ravaud P, Fechtenbaum J, Dougados $M$, Roux C. Accuracy and precision of 62 densitometers using a European spine phantom. Osteoporos Int 1999;10:14-19 


\section{Hoofdstuk 2}

\section{Resultaten algemeen}

\subsection{Pillotstudie}

Gedurende de eerste maand van het onderzoek liepen de metingen en de enquêtering niet geheel synchroon. Tijdens deze periode werd aan de hand van de respons van de aangeschreven patiënten berekend hoeveel tijd en hoeveel en welke arbeidsinspanning er nodig waren om een optimale patiëntenstroom naar het onderzoekscentrum in stand te houden. Vanaf de start werden er 24 BMD metingen per dag verricht. Na de eerste maand bleek de technische kwaliteit van de BMD metingen goed en constant te zijn. Een zestal BMD metingen uit die periode bleek niet te beoordelen en werden uit het bestand verwijderd. Door de patiènten uit te nodigen wat vroeger dan de geplande afspraak in het onderzoekscentrum aanwezig te zijn, bleken we in staat binnen de beschikbare tijd de gewenste informatie te verzamelen.

Wegens mogelijke onvolkomenheden van technische aard en/of het ontbreken van voldoende gegevens, besloten we de resultaten van de pilotstudie niet in de statistische analyse op te nemen.

\subsection{Compliance, oproep en respons}

Het bleek niet mogelijk om alle deelnemende vrouwen een enquête te laten invullen. Ook het afnemen van een voedingsanamnese was niet altijd mogelijk. Daarbij speelden oorzaken als onvermogen van sommige patienten om vragen goed te lezen of goed te beantwoorden en slechthorendheid van sommige patienten een rol. Ook het oproepen van de steekproef van de geexcludeerde vrouwen stuitte zo nu en dan op problemen. Een aantal van deze vrouwen bleek niet in staat naar de praktijk te komen, passend bij de aanvankelijk gehanteerde exclusiecriteria. Het aantal vrouwen dat niet wenste deel te nemen was iets groter dan in de groep geîncludeerde vrouwen. Als reden werd meestal opgegeven dat het hun te veel moeite kostte om naar het onderzoekscentrum te komen. Ook werd door sommigen aangegeven, dat het onderzoek te weinig belang voor hen had. Om tegemoet te komen aan deze patiënten werd hun aangeboden, dat zij thuis opgehaald en na het onderzoek weer naar huis gebracht zouden worden. De vervoersregeling deed velen besluiten toch aan de studie deel te nemen. Mogelijk heeft die regeling er toe bijgedragen, dat de opkomst onder de geexxcludeerde vrouwen uiteindelijk even groot bleek te zijn als onder de geincludeerde vrouwen. 
Tabel 1. Aantal vrouwen van 50 tot 80 jaar in 12 huisartspraktijken, aantal opgeroepen en aamtal onderzochte vrouwen.

\begin{tabular}{|c|c|c|c|c|}
\hline praktijk & $\begin{array}{l}\text { aantal vrouwen } \\
\text { per praktijk }\end{array}$ & $\begin{array}{l}\text { opgeroepen } \\
\text { vrouwen }\end{array}$ & $\begin{array}{l}\text { onderzochte } \\
\text { vrouwen }\end{array}$ & $\begin{array}{l}\text { opkomst } \\
\text { in procenten }\end{array}$ \\
\hline 1 & 880 & 675 & 515 & $76,2 \%$ \\
\hline 2 & 793 & 694 & 589 & $84,8 \%$ \\
\hline 3 & 352 & 301 & 237 & $78,7 \%$ \\
\hline 4 & 415 & 208 & 174 & $83,6 \%$ \\
\hline 5 & 394 & 288 & 179 & $62,2 \%$ \\
\hline 6 & 1627 & 1257 & 776 & $61,7 \%$ \\
\hline 7 & 440 & 279 & 218 & $78,1 \%$ \\
\hline 8 & 700 & 545 & 434 & $79,6 \%$ \\
\hline 9 & 706 & 417 & 341 & $81,7 \%$ \\
\hline 10 & 1485 & 751 & 654 & $87,0 \%$ \\
\hline 11 & 854 & 590 & 395 & $66,9 \%$ \\
\hline 12 & 461 & 241 & 213 & $88,4 \%$ \\
\hline totaal & 9107 & 6246 & 4725 & $75,6 \%$ \\
\hline
\end{tabular}

Bij de 23 deelnemende huisartsen in 12 praktijken, waren in totaal 9107 vrouwen van 50-80 jaar ingeschreven. De huisartsen screenden allen op in- en exclusiecriteria. Van alle vrouwen voldeden er 5303 aan de inclusiecriteria, 3804 vrouwen werden geëxcludeerd. De vrouwen die voldeden aan de inclusiecriteria plus 943 van de overige vrouwen werden opgeroepen voor deelname aan het onderzoek. Van deze 6246 vrouwen gaven er 4725 gehoor aan de oproep. Tabel 1 toont per praktijk het aantal vrouwen van 50 tot 80 jaar, het aantal opgeroepen vrouwen en het aantal vrouwen van wie de botdichtheid werd gemeten (=responders). (Zie ook het stroomdiagram op pagina 12) Het percentage vrouwen, dat volgens de huisartsen voldeed aan de inclusiecriteria, verschilde per praktijk. Een van de oorzaken kan zijn, dat de samenstelling van de praktijkpopulatie varieerde. Zo verschilde het aantal vijfenzestigplussers per praktijk soms aanmerkelijk (voorbeeld: $8 \%$ in praktijk $1,14 \%$ in praktijk 2). Onderzocht werd of door de exclusieprocedure selectiebias was opgetreden. Daartoe werden de percentages geexcludeerden per leeftijdscategorie berekend. Respectievelijk $19,16,15,15$, 17 en $20 \%$ van de 5-jaars categorieën was geëxcludeerd. Het percentage geëxcludeerden onder en boven de 65 jaar bleek daarmee exact gelijk aan het percentage geëxcludeerden in de totale studiepopulatie $(16,7 \%)$.

De opkomst, als percentage van het aantal opgeroepen vrouwen, was gemiddeld $75,6 \%$. Deze score houdt in dat we van 52\% (4725/9107) van de totale vrouwelijke populatie van 50-80 jaar ingeschreven in 12 huisartspraktijken, de BMD hebben gemeten. Per praktijk waren er grote verschillen in opkomst. Onderzocht werd of de geregistreerde verschillen, met als uitersten $61,7 \%$ en $88,4 \%$, mede bepaald werden door de afstand tussen de betreffende huisartspraktijk en het onderzoekscentrum. Daarbij werd er vanuit gegaan dat de huisartspraktijk centraal binnen de praktijk- 
populatie was gelegen Eveneens werd nagegaan of de aard van de ziektekostenverzekering (ziekenfonds of particulier) invloed had op de opkomst. Dit laatste op grond van de veronderstelling dat de particulierverzekerden vaker over eigen vervoer zouden beschikken dan de ziekenfondsverzekerden en om die reden mogelijk gemakkelijker waren te motiveren tot deelname aan het onderzoek. De 12 huisartspraktijken werden ingedeeld in drie categorieèn $0-5,6-10$ en 11-20 km verwijderd van het onderzoekscentrum. Tabel 2 toont het aantal patiènten per categorie, de opkomst (\%) en de sprejding (\%). De gevonden verschillen zijn niet groot maar de conclusie lijkt gerechtvaardigd dat de opkomst het grootst is bij een beperkte afstand tot het onderzoekscentrum. Begrijpelijk want naarmate de afstand tot het onderzoekscentrum groter is, zullen er meer vrouwen zijn die van het openbaar vervoer gebruik moeten maken. Ongemak en kosten zullen dan bij het besluit om deel te nemen aan het onderzoek mogelijk een rol gaan spelen.

Tabel 2. Opkomst per praktijk in relatie tot afstand van praktijk tot onderzoekscentrum

\begin{tabular}{|c|c|cc|c|}
\hline $\begin{array}{c}\text { afstand } \\
\text { tot praktijk }\end{array}$ & $\begin{array}{c}\text { opgeroepen } \\
\text { vrouwen }\end{array}$ & $\begin{array}{c}\text { opkomst in } \\
\text { aantal en }(\%)\end{array}$ & $\begin{array}{c}\text { spreiding } \\
\text { naar praktijk }\end{array}$ \\
\hline 0 tot $5 \mathrm{~km}$ & 2440 & 2085 & $(85,4)$ & $74,5 \%-88,4 \%$ \\
\hline 5 tot $9 \mathrm{~km}$ & 1932 & 1291 & $(66,8)$ & $61,7 \%-76,2 \%$ \\
\hline 10 tot $20 \mathrm{~km}$ & 1840 & 1349 & $(73,3)$ & $62,2 \%-81,7 \%$ \\
\hline totaal & 6246 & 4725 & $(75,6)$ & $61,7 \%-88,4 \%$ \\
\hline
\end{tabular}

Steekproefsgewijs werd in vier praktijken onderzocht of de opkomst voor wat betreft de verhouding particulier/ziekenfondsverzekerden overeenkwam met de in de desbetreffende praktijk bekende verhouding particulier/ziekenfondsverzekerden. Door de huisartsen van de vier praktijken werd de verhouding particulier/ziekenfondsverzekerden aan ons opgegeven in percentages (bij benadering omdat het aantal particulierverzekerde patiënten niet altijd exact bekend was). De verhouding onder de onderzochte vrouwen kon eenvoudig uit de door ons geregistreerde gegevens worden berekend. Deze steekproef betrof 2703 vrouwen van $50-80$ jaar ingeschreven in vier praktijken. Van hen was $23 \%(621 / 2702)$ particulier verzekerd. Van de 2703 vrouwen bezochten $1528(56,5 \%)$ vrouwen het onderzoekscentrum. Van de onderzochte vrouwen bleken eveneens $23 \%(358 / 1528)$ particulierverzekerd. Tabel 3 laat zien hoe de percentages over de vier praktijken waren verdeeld. 
Tabel 3. Verhouding particulier-en ziekenfondswerzekerden in procenten

\begin{tabular}{|c|c|c|}
\hline praktiijk & $\begin{array}{l}\text { verhouding } \\
\text { particulier/ziekenfonds } \\
\text { opgegeven door huisarts }\end{array}$ & $\begin{array}{c}\text { verhouding } \\
\text { particulier/ziekenfonds } \\
\text { onder de onderzochte vrouwen }\end{array}$ \\
\hline a & $18 / 82$ & $20 / 80$ \\
\hline$b$ & $15 / 85$ & $15 / 85$ \\
\hline c & $30 / 70$ & $34 / 66$ \\
\hline d & $24 / 76$ & $17 / 83$ \\
\hline totaal & $23 \%$ particulier & $23 \%$ particulier \\
\hline
\end{tabular}

Uit dit resultaat kan worden afgeleid dat de mate van opkomst per praktijk onafhankelijk is van de verhouding particullier/ziekenfondsverzekerden in de desbetreffende praktijk.

Non-responders zouden een selecte groep van de populatie kunnen vormen. Per definitie is deze groep moeilijk te onderzoeken. De non-responders in de praktijk van de onderzoeker $(n=118)$ bleken zich als groep niet te onderscheiden van de responders (de gemiddelde leeftijd en de percentages geïncludeerde en geèxcludeerde patiënten waren voor beide groepen gelijk). Van deze 118 non-responders kwamen er 20 tijdens de studie toevallig in contact met de onderzoeker. Hen werd verzocht toch hun BMD te laten meten. Een patiënte weigerde, 19 anderen lieten zich overtuigen. Deze kleine subgroep verschilde niet noemenswaardig van de totale populatie.

(zie ook hoofdstuk 3, pagina 35)

\subsection{Beschrijving onderzoekspopulatie}

Alleen de gegevens van de vrouwen die na de pilotstudie werden onderzocht zijn gebruikt voor statistische analyses. Voor diverse artikelen werden de analyses uitgevoerd voor zowel de totale studiepopulatie ('all patients', $n=4203$ ) als voor de subgroep van vrouwen die onder behandeling waren van de huisarts of van een specialist (de .consulting patients' $n=2107$ ). Ten aanzien van de populaties 'all patients'en 'consulting patients' geeft tabel 4 het overzicht van de onderzochte niet-discrete variabelen, terwijl tabel 5 het overzicht toont van de discrete variabelen. De subgroep 'consulting patients' in tabel 4 , blijkt voor wat betreft de leeftijd iets te verschillen van de totale studiepopulatie. Dat ligt voor de hand omdat op latere leeftijd een grotere morbiditeit aanwezig is en de patiente op leeftijd dus vaker onder behandeling zal zijn. De belangrijkste verschillen tussen 'all patients' en 'consulting patients' in tabel 5 is het grotere percentage patiènten dat langer dan 5 jaar de pil gebruikte. De overige variabelen blijken bij benadering in de totale populatie en in de subgroep even vaak voor te komen. De tabellen $6 \mathrm{a}$ en $6 \mathrm{~b}$ tonen de resultaten van de bivariabele analyses. Weergegeven is de 
relatie tussen de discrete variabelen en de BMD in de populatie 'all patients' en in de subgroep 'consulting patients'. Omdat het aantal 'missings' per onderzochte variabele iets verschilt, kunnen de totalen in deze tabellen per variabele iets verschillen. In de populatie 'all patients' varieert het aantal missings tussen $0,9 \%$ tot 3,5\%. Tabel 7 toont de bivariabele analyse van alle continue variabelen versus de $\mathrm{BMD}$, zowel voor "all patients' als voor 'consulting patients".

Table 4. Description of the study population; non-discrete variables.

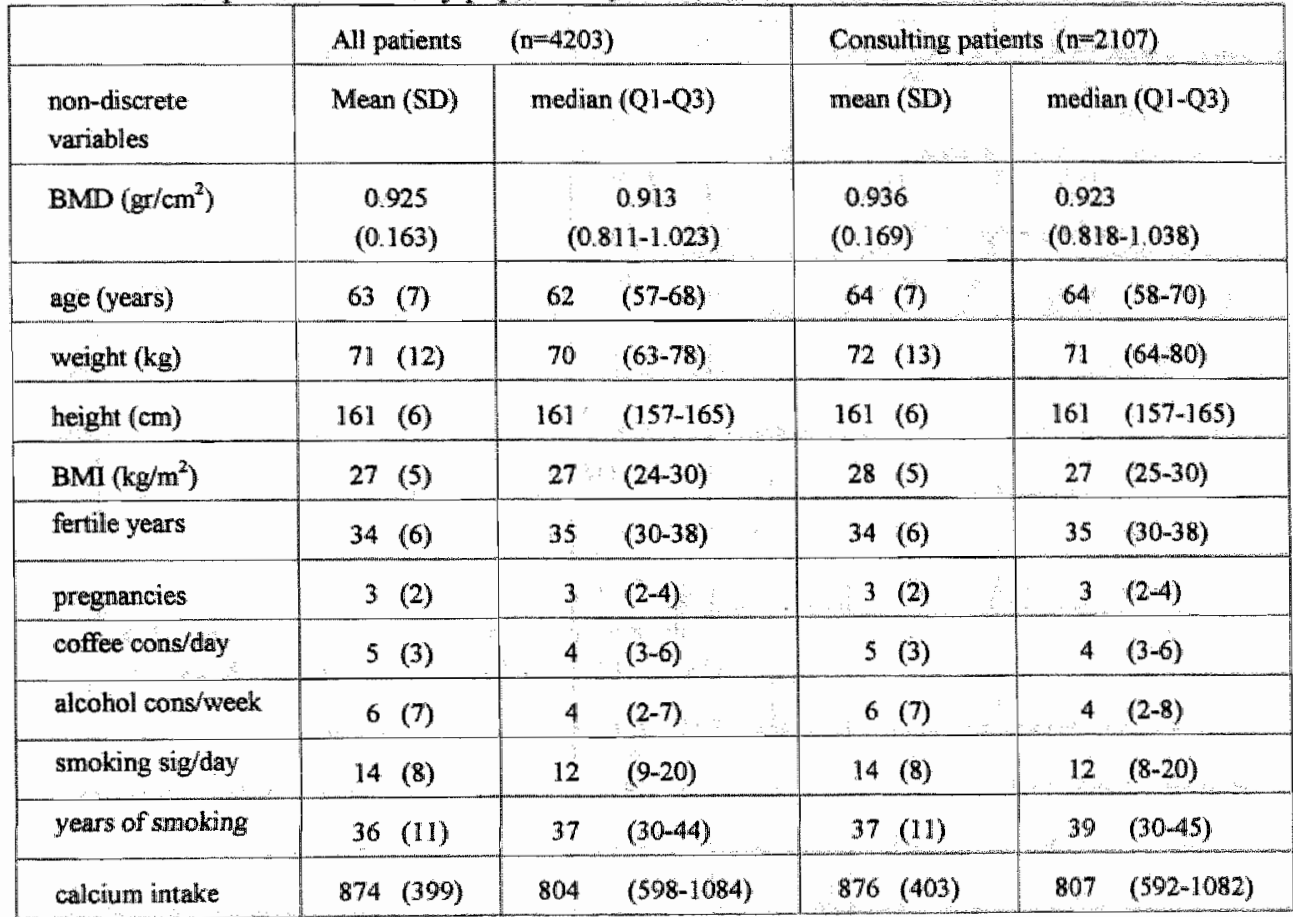


Tabel 5 Description of the study population discrete variables. Numbers of patients and percentages are given.

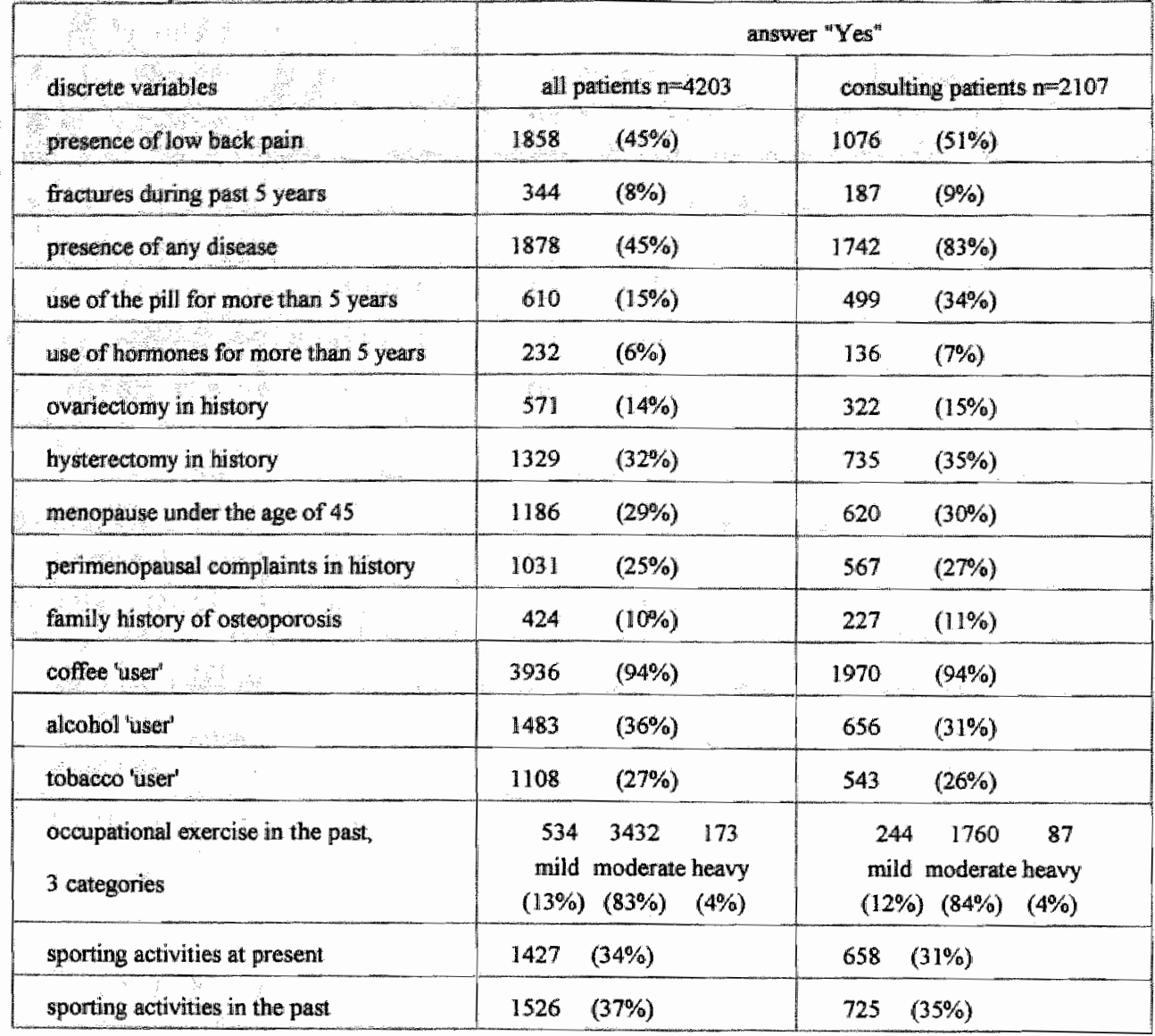


Resultaten algemeen: beschrijving onderzoekspopulatie

Table 6 . Bivariate analygis of discrete variables in all patients (n-4203), mmbers of patients ame given.

\begin{tabular}{|c|c|c|c|c|c|c|c|}
\hline \multirow{3}{*}{\multicolumn{2}{|c|}{ Independen wariables }} & \multicolumn{4}{|c|}{ dependent wamble (BMD in grfmin) } & \multirow{2}{*}{\multicolumn{2}{|c|}{$\frac{\mathrm{CH}-\mathrm{SQ} \mathrm{p}-\text { value }}{\mathrm{BMD}}$}} \\
\hline & & \multicolumn{2}{|c|}{$\mathrm{BMD}$} & \multicolumn{2}{|c|}{ BMD } & & \\
\hline & & $\leq 0,800$ & $>0.800$ & $<0,970$ & $>0.970$ & $\leq 0,800$ & $<0.970$ \\
\hline \multirow{2}{*}{$\begin{array}{l}\text { presence of low } \\
\text { backpain }\end{array}$} & yes & 413 & 1445 & 1162 & 696 & 0249 & 0.005 \\
\hline & no & 548 & 1760 & 1540 & 768 & $\therefore$ & 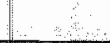 \\
\hline \multirow{2}{*}{$\begin{array}{l}\text { fracture(s) during } \\
\text { poast } 5 \text { years }\end{array}$} & yes & 119 & 225 & 265 & 79 & 0,000 & 00,000 \\
\hline & mo. & 838 & 2973 & 2428 & 1383 & & $\vdots$ \\
\hline \multirow{2}{*}{$\begin{array}{l}\text { presence of any } \\
\text { disease }\end{array}$} & yes & 409 & 1469 & 1177 & 701 & 0.068 & 0.007 \\
\hline & mo & 553 & 1735 & 1525 & 763 & & \\
\hline \multirow{2}{*}{$\begin{array}{l}\text { we of the pill for } \\
\text { more than } 5 \text { years }\end{array}$} & yes & 104 & 506 & 365 & 245 & 40,000 & 0,005 \\
\hline & no: & 848 & 2654 & 2304 & 1198 & 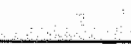 & 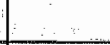 \\
\hline \multirow{2}{*}{$\begin{array}{l}\text { use of hormones } \\
\text { more than } 5 \text { years }\end{array}$} & yes & 29 & 203 & 112 & 120 & $<0000$ & $<0,000$ \\
\hline & no & 896 & 2930 & 2515 & 1311 & & $3^{\prime}$ \\
\hline \multirow{2}{*}{$\begin{array}{l}\text { ovariectiony } \\
\text { in histiory }\end{array}$} & yes & 125 & 446 & 387 & 184 & 0.467 & 0.116 \\
\hline & no & 836 & 2756 & 2313 & 1279 & & \\
\hline \multirow{2}{*}{$\begin{array}{l}\text { hystemectomy } \\
\text { in history }\end{array}$} & yes & 268 & 1062 & 821 & 509 & 0.001 & 0.410 \\
\hline & no & 693 & 2140 & 1878 & 955 & & \\
\hline \multirow{2}{*}{$\begin{array}{l}\text { unge of menopanise } \\
\text { under the age of } 45\end{array}$} & yes & 285 & 901 & 780 & 406 & 0.447 & 0.492 \\
\hline & no & 671 & 2256 & 1892 & 1035 & & \\
\hline \multirow{2}{*}{$\begin{array}{l}\text { peri-menopausal } \\
\text { complaints }\end{array}$} & yes & 199 & 832 & 626 & 405 & 0,001 & 0.001 \\
\hline & no & 762 & 2368 & 2073 & 1057 & & \\
\hline \multirow{2}{*}{$\begin{array}{l}\text { positive family } \\
\text { history of fractures }\end{array}$} & yes & 116 & 308 & 292 & 132 & 0.028 & 0.068 \\
\hline & no & 845 & 2892 & 2407 & 1330 & & \\
\hline \multirow[t]{2}{*}{ coffere 'user' } & yes & 917 & 3019 & 2541 & 1395 & 0,465 & 0091 \\
\hline & no & 57 & 210 & 186 & 81 & & \\
\hline \multirow[t]{2}{*}{ alcohol tiser: } & yes & 332 & 1151 & 959 & 524 & 0.412 & 0.820 \\
\hline & no & 630 & 2050 & 1742 & 938 & & \\
\hline \multirow[t]{2}{*}{ smoking 'user' } & yes & 255 & 853 & 732 & 376 & 0.945 & 0,332 \\
\hline & no & 706 & 2348 & 1968 & 1086 & & \\
\hline \multirow{3}{*}{$\begin{array}{l}\text { occupation: light } \\
\text { moderate } \\
\text { hearyy }\end{array}$} & 0 & 123 & 411 & 348 & 186 & 0.056 & 0.887 \\
\hline & 1 & $78 \rrbracket$ & 2651 & 2222 & 2210 & & \\
\hline & 2 & 53 & 120 & 115 & 58 & & \\
\hline \multirow{2}{*}{$\begin{array}{l}\text { sporting activities } \\
\text { at present }\end{array}$} & yes & 318 & 1109 & 927 & 500 & 0.370 & 0.924 \\
\hline & no & 643 & $20 \%$ & 1772 & 962 & & \\
\hline sporting activities & yess & 324 & 1202 & 968 & 558 & 0.030 & 0.141 \\
\hline in the past & no & 637 & 1998 & 1731 & 904 & & \\
\hline
\end{tabular}




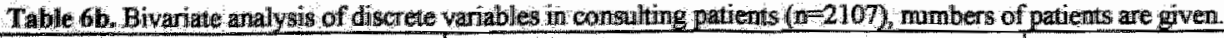

\begin{tabular}{|c|c|c|c|c|c|c|c|}
\hline \multirow{3}{*}{ Hodependen variables } & & \multicolumn{4}{|c|}{ dependew wariable (BMD in $\left.\mathrm{gr} / \mathrm{cm}^{2}\right)$} & \multirow{2}{*}{\multicolumn{2}{|c|}{$\frac{\text { CHISQ P-ralue }}{\text { BMD }}$}} \\
\hline & & \multicolumn{2}{|c|}{$\mathrm{BNAD}$} & \multicolumn{2}{|c|}{$\mathrm{BMD}$} & & \\
\hline & & 50,800 & $>0.800$ & $\$ 0970$ & 970 & \multicolumn{2}{|c|}{$\leq 0970$} \\
\hline \multirow{2}{*}{$\begin{array}{l}\text { pressence of low } \\
\text { brack pain- }\end{array}$} & yes: & 233 & 843 & 663 & 413 & 0873 & 0.806 \\
\hline & no & 226 & 804 & 640 & 390 & & \\
\hline \multirow{2}{*}{$\begin{array}{l}\text { fracture(s) during } \\
\text { past } 5 \text { years }\end{array}$} & yes & 65 & 122 & 145 & 42 & $\$ 0,000$ & 40.000 \\
\hline & no & 392 & 1519 & 1152 & 759 & & \\
\hline \multirow{2}{*}{$\begin{array}{l}\text { presence of any } \\
\text { disense. }\end{array}$} & yes: & 382 & 1360 & 1084 & 658 & 0.745 & 0.461 \\
\hline & & 77 & 287 & 219 & 145 & & \\
\hline \multirow{2}{*}{$\begin{array}{l}\text { ase of the pill for } \\
\text { nore than } 5 \text { years }\end{array}$} & yes & 61 & 237 & 180 & 118 & 0,551 & 0.577 \\
\hline & no: & 392 & 1389 & 1106 & 675 & & \\
\hline \multirow{2}{*}{$\begin{array}{l}\text { use of homonus for } \\
\text { more than } 5 \text { years }\end{array}$} & yes: & 18 & 118 & 65 & 71 & 0.016 & 0,001 \\
\hline & no & 419 & 1486 & $\mathbb{1 1 9 3}$ & 712 & & \\
\hline \multirow{2}{*}{$\begin{array}{l}\text { ovariectomy } \\
\text { on history }\end{array}$} & yes: & 77 & 245 & 213 & 109 & 0.322 & 0,087 \\
\hline & no & 382 & 1400 & 1089 & 693 & & \\
\hline \multirow{2}{*}{$\begin{array}{l}\text { hystereetiony } \\
\text { in history }\end{array}$} & yes: & $\llbracket 45$ & 590 & 437 & 298 & 0.070 & 0.100 \\
\hline & no & 314 & 1053 & 863 & 504 & & \\
\hline \multirow{2}{*}{$\begin{array}{l}\text { age of menopanse } \\
\text { under the age of } 45\end{array}$} & yes & 146 & 474 & 390 & 230 & 0.235 & 0.553 \\
\hline & no & 309 & 1149 & 897 & 561 & & \\
\hline \multirow{2}{*}{$\begin{array}{l}\text { peri/post menopausal } \\
\text { complaints }\end{array}$} & yes & 109 & 458 & 338 & 229 & 0.078 & $0.19]$ \\
\hline & no & 350 & 1185 & 963 & 572 & & \\
\hline \multirow{2}{*}{$\begin{array}{l}\text { positive family history } \\
\text { of csteoporotic fractures }\end{array}$} & yes & 59 & 168 & 152 & 75 & 0.109 & 0.096 \\
\hline & no & 400 & 1475 & 1149 & 726 & & \\
\hline \multirow[t]{2}{*}{ colfee "teser" } & yesi & 41 & 1539 & 1214 & 756 & 0.846 & 0.343 \\
\hline & no & 29 & 1.08 & 90 & 47 & & \\
\hline \multirow[t]{2}{*}{ alcohol "wasen" } & yes & 137 & 519 & 397 & 259 & 0.465 & 0.370 \\
\hline & no & 323 & 1125 & 906 & 542 & & \\
\hline \multirow[t]{2}{*}{ smoking "tuser" } & yes & 127 & 416 & 354 & 189 & 0,306 & 0,068 \\
\hline & no & 332 & 1228 & 948 & 612 & & \\
\hline \multirow{3}{*}{$\begin{array}{l}\text { occupation light } \\
\qquad \begin{array}{l}\text { moderate } \\
\text { breavy }\end{array}\end{array}$} & 0 & 58 & 186 & 162 & 82 & 0.640 & 0.291 \\
\hline & 1 & 379 & 1381 & 1078 & 682 & & \\
\hline & 2 & 21 & 66 & 55 & 32 & & \\
\hline \multirow{2}{*}{$\begin{array}{l}\text { sporting activities: } \\
\text { at present }\end{array}$} & yes & 146 & $\$ 12$ & 404 & 254 & 0.792 & 0.752 \\
\hline & no & 313 & 1131 & 897 & 547 & & \\
\hline \multirow{2}{*}{$\begin{array}{l}\text { sporting activitiv } \\
\text { in the past }\end{array}$} & yes & 142 & 583 & 448 & 277 & 0.070 & 0.945 \\
\hline & no. & 317 & 1060 & 853 & 524 & & \\
\hline
\end{tabular}


Table 7. Bivariate analysis, non-diserete wariables.

\begin{tabular}{|c|c|c|c|c|c|c|}
\hline \multirow{3}{*}{$\begin{array}{l}\text { independent } \\
\text { variables }\end{array}$} & \multicolumn{6}{|c|}{ dependent uariable (BMD) } \\
\hline & \multicolumn{3}{|c|}{ all patients $(\mathrm{n}=4203)$} & \multicolumn{3}{|c|}{ consulting patients $(\mathrm{m}=2107)$} \\
\hline & $\pi^{*}$ & $p$-value of $r$ & $\begin{array}{l}\text { regression } \\
\text { coefficient }\end{array}$ & $\mathbf{r}$ & $\mathrm{p}$-value of $\mathrm{r}$ & $\begin{array}{l}\text { regression } \\
\text { coefficient: }\end{array}$ \\
\hline age (years) & -17 & $<.001$ & -004 & -13 & $<001$ & .003 \\
\hline weight (kg) & 36 & $<.001$ & .005 & .40 & $<001$ & .005 \\
\hline height $(\mathrm{cm})$ & .16 & $<001$ & .004 & .13 & $<001$ & .004 \\
\hline $\mathrm{BMI}\left(\mathrm{kg} / \mathrm{m}^{2}\right)$ & 29 & $<.00 \rrbracket$ & .011 & 35 & $<001$ & 013 \\
\hline fertile years ( $n$ ) & .08 & $<001$ & .002 & .08 & $<001$ & .002 \\
\hline pregnancies (n) & -.03 & .08 & -.002 & -.01 & .72 & nihil \\
\hline coffee (cons/day) & .03 & .11 & 001 & .01 & .63 & nihil \\
\hline alcohol (cons/day) & .02 & 45 & nihil & .07 & .14 & nihil \\
\hline smoking sig /day &. .00 & .49 & nihil & .03 & .53 & nihil \\
\hline smoking years & -.06 & .06 & nihill & -.08 & .07 & .001 \\
\hline $\begin{array}{l}\text { calcium intake } \\
\mathrm{mg} / \mathrm{day}\end{array}$ & .05 & .003 & nihil & .05 & .02 & nihil \\
\hline
\end{tabular}

* Pearson's correlation coefficient.

\section{Metingen in Nederland}

Simultaan werden er in Nederland voor dezelfde trial als genoemd op pagina 10 op zes verschillende plaatsen (verspreid over het land, zowel stad, platteland als verstedelijkt platteland) grote groepen vrouwen opgeroepen voor meting van de BMD. In maart 1994 was van meer dan 17000 vrouwen de BMD van de lumbale wervelkolom gemeten. De wijze waarop de vrouwen werden opgeroepen verschilde per plaats (al of niet met gebruik van een antwoordkaart bij de uitnodigingsbrief). De opkomstpercentages verschilden eveneens per plaats. Bijgehouden werd hoeveel van de onderzochte vrouwen een BMD-waarde hadden van meer dan 2SD onder de T-score. In tabel 8 zijn de resultaten weergegeven.

Tabel. 8. Vergelijking van de percentages vrouwen met een BMD van meer dan 2 SD onder de T-score in 6 regio"s in Nederland

\begin{tabular}{|l|c|c|c|c|c|c|c|}
\hline & Twente & Limburg & Groningen & Brabant 1 & Zuid-Holland & Brabant 2 & Gemiddeld \\
\hline $\mathrm{n}$ & 4348 & 4282 & 2823 & 2161 & 2496 & 1332 & \\
\hline $\mathrm{BMD} \leq-2 \mathrm{SD}$ & $37 \%$ & $35 \%$ & $32 \%$ & $40 \%$ & $32 \%$ & $37 \%$ & $36 \%$ \\
\hline
\end{tabular}


Het gemiddelde percentage van patiënten met een BMD meer dan 2 SD onder de norm T-score) in Limburg komt overeen $(35,4 \%$ versus $35,6 \%)$ met het gemiddelde percentage van de 6 centra.

\subsection{Samenvatting}

Bij de 23 deelnemende huisartsen uit 12 praktijken waren in totaal 9107 vrouwen van 50-80 jaar ingeschreven. Van hen voldeden er 5303 aan de inclusiecriteria. Deze vrouwen plus 943 van de overige vrouwen werden opgeroepen voor deelname aan ons onderzoek. Van deze 6246 vrouwen gaven er 4725 gehoor aan de oproep, een opkomst van $75,6 \%$. Dit houdt in dat van 52\% (4725/9107) van alle vrouwen van 50-80 jaar, ingeschreven in de 12 huisartspraktijken, de BMD is gemeten. Het onderzoek werd gestart met een pilotstudie van een maand. Gedurende die maand werden technische aspecten wan de BMD metingen verbeterd, het studie protocol aangescherpt en werd de patientenstroom naar (en van) het onderzoekscentrum geoptimaliseerd. De gegevens van alle vrouwen die na de pilotstudie werden onderzocht werden geanalyseerd ( $\mathrm{N}=4203$, hierna de studiepopulatie).

De opkomst bleek onafhankelijk van de afstand tot de huisartspraktijk waartoe de patiënten behoorden en het onderzoekscentrum. Ook de aard van de ziektekostenverzekering (ziekenfondsverzekerd of particulierverzekerd) had geen invloed op de opkomst. Met een goede vervoersvoorziening en een soepele afspraakprocedure werd getracht de compliance te bevorderen.

Een kleine groep non-responders (118) uit de praktijk van de onderzoeker kon nader worden beschouwd. Deze non-responders bleken zich als groep niet te onderscheiden van de responders. De bij de huisarts ingeschreven patiènten werden verdeeld in twee groepen: niet onder behandeling en wel actueel onder behandeling van huisarts of specialist, de 'consulting patients'. In de beschrijving van de totale studiepopulatie ('all patients') en de subgroep van 2107 'consulting patients' bleek de subgroep voor wat betreft de leeftijd van de totale studiepopulatie te verschillen. Dat ligt voor de hand omdat op latere leeftijd een grotere morbiditeit aanwezig is. In de subgroep 'consulting patients' valt op dat het percentage vrouwen dat langer dan 5 jaar de pil gebruikte veel groter is dan in de totale populatie. De overige variabelen komen in beide groepen bij benadering even vaak voor.

Simultaan werden er in 6 centra in Nederland botdichtheidmetingen verricht. Het aantal vrouwen met een BMD van meer dan 2 SD onder de norm ( $T$-score) in Limburg komt overeen $(35,4 \%$ versus $35,6 \%$ ) met het gemiddelde percentage van deze centra. 


\section{Hoofdstuk 3}

Construction of an algorithm for quick detection of patients with low bone mineral density and its applicability in daily general practice.

1. D.J.M. van der Voort, D (1), general practitioner

2. G.J. Dinant, $\mathrm{MD}, \mathrm{PhD}$, professor of Clinical Research in General Practice (1)

3. P.E.L.M. Rinkens, research-assistant (1)

4. C.J.M. van der Voort-Duindam, data manager (1)

5. J.W.J van Wersch, $\mathrm{PhD}$, clinical chemist (2)

6. P.P. Geusens, $\mathrm{MD}, \mathrm{PhD}$, professor of Rheumatology (3)

(1): University Maastricht, Department of General Practice and Research Institute for Extramural and Transmural Health Care, Maastricht, The Netherlands

(2): Department of Clinical Chemistry, De Wever Hospital, Heerlen, The Netherlands

(3): Department of Internal Medicine, Academic Hospital, Maastricht, The Netherlands

Accepted for publication in Journal of Clinical Epidemiology 


\section{ABSTRACT}

Objective: To construct a quick algorithm to detect patients with low bone mineral density (BMD) and osteoporosis and determine its applicability in daily general practice.

Design. Cross-sectional study in all 9107 postmenopausal women, aged 50-80, registered at 12 general practice centres.

Subjects and measurements: All healthy women (5303) and $25 \%$ of the remaining group (943/3804) were invited to participate. Out of 6246 invited women, $4725(76 \%)$ participated. The women were questioned (state of health, medical history, family history and food questionnaire) and examined (weight, height, body mass index and BMD of the lumbar spine).

Statistics: Multivariable, stepwise backward and forward logistic regression analyses were performed, with BMD of the lumbar spine (L2-L4, cutoff points at $0.800 \mathrm{~g} / \mathrm{cm}^{2}$ for osteoporosis and $0.970 \mathrm{~g} / \mathrm{cm}^{2}$ for low BMD) as the dependent variable. An algorithm was constructed with those variables that correlated statistically significantly and clinically relevantly with the presence of both osteoporosis and low BMD.

Results: The prevalence of osteoporosis was 23\%, that of low BMD was $65 \%$. Only three variables (age, BMI and fractures) were statistically significant and clinically relevantly correlated with the presense of both osteoporosis and low BMD. Age (OR 2.70 for osteoporosis and OR 1.77 for low BMD) and fractures during the past five years (OR 3.60 for osteoporosis and OR 2.85 for low BMD) were found to be the key predictors. From the algorithm the absolute risks varied from $9 \%$ to $51 \%$ for osteoporosis and from $48 \%$ to $84 \%$ for low BMD. The corresponding relative risks varied from 1.0 to 5.7 and from 1.0 to 1.8 . Conclusions: Using an algoritm with age, BMI and fracture history subgroups at high risk could be identified. However, in whatever combination, many women with osteoporosis could not be identified. Despite the differences in methods, we found predictors for osteoporosis which were comparable with the results of other cross-sectional studies, meaning that the first selection of patients at high risk for low BMD can be done adequately by both specialists and GPs. 


\section{INTRODUCTION}

With the ageing and longer survival of the western (female) population, the occurrence of chronic diseases is of increasing relevance in general practice. In this respect, osteoporosis is important, because its complications are related to major morbidity (including social restraint), and even mortality ${ }^{(1-4)}$. It is therefore of interest in daily general practice to detect patients in those stages of reduced bone mineral density (BMD) in which pharmaceutical interventions aiming to prevent osteoporotic fractures may still be effective. However as in other chronic diseases, it is unclear what patient caracteristics predict early stages of osteoporosis and wether and how these caracteristics can be identified easily in everyday general practice, e.g. without referring the patient to a hospital for BMD measurement $t^{(5-10)}$.

So far, diagnostic research has taken place mainly in totally unselected populations, or populations of patients referred to the (outpatient) clinic ${ }^{(11-14)}$. Furthermore, although the incidence of osteoporotic fractures is being closely monitored, it is virtually unknown how many osteoporotic patients are present in the population of a particular general practice $e^{\left(11_{1} 15-\right.}$ 17). Due to the lack of this information, definite and easily applicable guidelines for the detection of patients with low BMD (otherwise than with DEXA and radiography) in general practice are not yet available ${ }^{(18-23)}$. The present study concentrates on this issue. In a crosssectional study among post-menopausal women between 50 and 80 years of age, 'easily obtainable' features which were potentially related to low BMD, were compared with the results of Dual Energy X-ray Absorptiometry (DEXA) measurements. 'Easily obtainable' was defined as: obtainable within one 10 minutes consultation and without the use of invasive examinations.

\section{METHOD}

\section{Patients}

23 general practitioners (GPs) from 12 general practice centers in the south-eastern part of The Netherlands participated. The region can best be described as consisting of two cities surrounded by suburban villages.

The study aimed at including post-menopausal women between 50 and 80 years of age. Postmenopausal was defined as: no menstruation during the past 12 months. Between October 1992 and March 1994, the GPs identified all women between 50 and 80 registered in their centres (see figure 1 , flow chart). Of the 9107 women identified 5303 healthy postmenopausal women were then selected by the GPs. The criteria for being healthy (appendix F) were used to select patients for several concomitant therapeutic trials. These 5303 patients, as well as every fourth woman (943) of the remaining group of 3804 patients ('excluded" patients), were selected for participation in the study. All women received written 
information on the purpose of the study and an invitation to participate. Shortly afterwards, these $6246(5303+943)$ women were telephoned by the practice nurse of their own GP, who checked again for age and menopausal state of the women and invited them once again to participate in the study. Of the 6246 women, 4725 finally met the age and menopausal criteria and were willing to participate. These 4725 women received an appointment for a visit to the first author's practice centre. At the beginning of this visit, informed consent was obtained from all 4725 women.

\section{Measurements}

Each visit started with measurements of weight, height and $B M D$, performed by four experienced and specially trained research nurses. A questionnaire was then filled out by the patient and immediately checked by one of the research nurses, in the presence of the patient. Only at the request of the patient, but not until all data had been recorded, was the patient was informed of her BMD, in terms of "normal" or 'low'. Weight was measured in kg, using one Seca scale, to the nearest 500 grammes, with one upper layer of clothes and without shoes. The Seca scale was calibrated monthly. Height was measured in $\mathrm{cm}$, without shoes, with both heels and back against the wall, using one wallmounted centimetre scale. Weight and height were used to calculate the body mass index (BMI).

BMD of the lumbar spine was measured with one computer guided DEXA instrument (Hologic QDR-1000, Hologic Europe; Brussels, Belgium), located in the first author's practice centre ${ }^{(24-27)}$. The instrument was calibrated daily by one research nurse, using a phantom and a computer guided standard procedure.

If necessary, measurements were interrupted until technicians from Hologic had adjusted the instrument, on the same day. During the study period, the four research nurses attended four interrator reliability sessions. The results of the measurements are given as the mean BMD (in $\mathrm{g} / \mathrm{cm}^{2}$ ) of $\mathrm{L} 2-\mathrm{LA}$. In those cases where measurements failed, the investigator immediately checked for any abnormalities which might be interfering with osteoporosis, e.g. substantial scoliosis, or excessive osteophytosis. These patients were excluded from the data analysis The questionnaire concentrated on those variables for which published evidence suggested an association with osteoporosis or low BMD: current treatment for health complaints (including the presence of low back pain), fractures, presence of a disease, use of 'the pill', use of other hormones, ovariectomy, menopause before or after the age of 45 , years between menarche and menopause ('fertile years'), number of pregnancies, perimenopausal complaints, family history of osteoporosis, use of toxic substances (coffee, alcohol and tobacco), calcium intake and occupational exercise and sports in the present and past.

Occupational exercise was classified according to the Occupational Guide (TTS-beroepenklapper') of 'The Netherlands Institute of Applied Social Studies ${ }^{(28)}$. These codes were used to determine the physical strain on a person. The results were divided into three categories 
$(1+4=$ light, 2 -moderate and 3 -heavy). Calcium intake was measured with the help of a validated questionnaire ${ }^{(29-32)}$

\section{Statistics}

Statistical analysis was performed using the BMDP program ${ }^{(33)}$. BMD values (dependent variable) were dichotomized at $0.80 \mathrm{~g} / \mathrm{cm}^{2}$ (for osteoporosis) and $0.97 \mathrm{~g} / \mathrm{cm}^{2}$ (for osteopeniatosteoporosis = low BMD). The cutoff points corresponded to 2.5 and 1 standard deviations below the mean BMD of L2-L4, measured in a healthy adult female population aged 30 , using the Hologic QDR-1000 $0^{(34,35)}$.

The variable 'fractures' was dichotomized into those that had occurred during the past 5 years and older fractures. Five years was assessed to be the optimum between finding enough fractures to allow a statistical evaluation on the one hand, and loss to recall on the other. A 5 -year cutoff point was also chosen for the 'use of the pill' and 'other hormones'. Age was dichotomized at 60 years, since women over 60 years of age will definitely be postmenopausal. For BMI we chose a cutoff point of $27 \mathrm{~kg} / \mathrm{m}^{2}$, thereby enabling a comparison of our results with those from two important studies in The Netherlands ${ }^{(36,37)}$. These cutoff points as well as those for the remaining three non-discrete independent variables ( 35 fertile years, 2 pregnancies and $500 \mathrm{mg}$ calcium intake) were checked by entering them into receiver operating curve (ROC) analyses. The chosen cutoff points were all very close to the maximum of the sums of sensitivities and specificities. All discrete and dichotomized variables were then entered into a multivariable stepwise backward and forward logistic regression analysis. Those variables showing statistically significant odds ratios were entered into a final multivariable logistic regression analysis. In order to check for interactions, clinically relevant relationships between variables were added to this final model as product variables. The following 16 products were used: $\mathrm{BMI} \times \mathrm{x}$ height, $\mathrm{BMI} \mathrm{x}$ weight, height $\mathrm{x}$ weight, fractures $\mathrm{x}$ age, fractures $\mathrm{x}$ height, fractures $\mathrm{x}$ weight, fractures $\mathrm{X} B \mathrm{BM}$, fractures $\mathrm{x}$ hormones, fertility $\mathrm{x}$ age, fertility $\mathrm{x}$ fractures, fertility $\mathrm{x}$ hormones, fractures $\mathrm{x}$ hysterectomy, hormones $\mathrm{x}$ age, hormones $\mathrm{x}$ height, hormones $\mathrm{x}$ weight and hormones $\mathrm{x}$ BMI, in the first and final logistic regression analyses we used the Hosmer-Lemeshow goodness-of-fit test to assess the fit of the model to the data.

Of the remaining variables, only those that correlated statistically significant with the presence of both osteoporosis and low BMD, were selected for an algorithm. For each arm of the algorithm, absolute risks and relative risks were calculated. 


\section{RESULTS}

Of the 6246 invited patients, $4725(76 \%)$ underwent BMD measurement. During the first four weeks a pilot study was done. In this period there were practical limitations with respect to the simultaneous measurements of BMD on the one hand and the biometrical measurements and survey (questionnaire) on the other. Hence, only the data of those patients $(\mathrm{N}=4209)$ who entered the study after the first four weeks were used for the statistical analysis. Mean BMD $(0.927$, SD 0.159) in the $516(4725-4209)$ omitted patients was similar to the mean BMD $(0.925, \mathrm{SD} 0.163)$ in the analysed group $(\mathrm{N}=4209)$. Of the 4209 consecutive patients, we excluded 6 patients because of failure of the DEXA measurement. For $97 \%$ of the remaining 4203 patients, all data were available. The majority of the $3 \%$ patients with missing data consisted of individuals $(n=41)$ who were unable to fill out the questionnaire, even with the help of the nurse.

The characteristics of the study population are shown in Table la (non-discrete variables) and Table 16 (discrete variables). In table 2 , the mean BMD and the prevalence of osteoporosis have been stratified for age categories. The greatest decline in BMD takes place between 50 and 60 years of age. Over 65 years, mean BMD does not change between the age categories. However, the variability of BMD does increase with age (see the regarding SDs).

In assessing the external validity of our results, biometrical data (age, weight, height and BMI) were compared with recent Dutch population data from leading epidemiological surveys, i.e., The Rotterdam Study and surveys made by The Netherlands Organisation for Applied Scientific Research (TNO) and The National Central Buro of Statistics (CBS) ${ }^{(12,36,37)}$ (Table 3). The average data for our study population correspond well with these national data. With respect to the prevalence of co-morbidity, our data could be compared with those from two Dutch registration networks for morbidity in general practice (CMR and RNH $)^{(38,39)}$. We compared two common diseases that are relevant for daily practice and for osteoporosis: ischaemic heart conditions and diabetes mellitus. Using ICPC $\operatorname{codes}^{(40)}$, the prevalences of ischaemic heart diseases were found to be $14 \%$ in the RNH system and $16 \%$ in our study. For diabetes mellitus, prevalence was $7 \%$ both in the CMR and in our study population.

The prevalence of osteoporosis and that of low BMD was $23 \%$ and $65 \%$ respectively. The results of the multivariable logistic regression analysis are shown in Table 4 . Nine variables with a statistically significant relationship with BMD were entered into the final logistic regression analysis (Table 5). Two nonsignificant variables were added for the final logistic analysis: 'illness' (as an answer to the question: 'Are you suffering from a disease?') and hysterectomy (yes or no). Ilness $(\mathrm{N}=1878$ ) represents the possible relationship between 
osteoporosis and co-morbidity. Hysterectomy $(\mathrm{N}=1329)$ is implicitly correlated with the use of hormones. In a separate multivariable logistic regression analysis with the mentioned product variables we found similar results. The Hosmer-Lemeshow goodness-of-fit test indicated a good overall fit to the data of the models used ${ }^{(4)}$.

Eight variables (age, weight, BMI, fractures, presence of disease, fertile years, hysterectomy in history, and positive family history) in Table 5 were statistically significant for osteoporosis as well as for low BMD. Only three variables were entered into the algorithm (Table 6). Weight was replaced by BMI, since BMI is applicable for every woman, irrespective of her height. We decided to leave 'presence of disease', 'hysterectomy in history' and 'fertility years' out of the algorithm because of their marginal confidence intervals. Moreover, fertility years' has an implicit biological correlation with hysterectorny and use of hormones. Positive family history was left out, not only because of its marginal confidence interval, but also the limited reliability of this variable. The sequence of the variables in the algorithm follows the magnitude of the odds ratios. From the algorithm the absolute risks varied from $9 \%$ to $51 \%$ for osteoporosis and from $48 \%$ to $84 \%$ for low BMD. The corresponding relative risks varied from 1.0 to 5.7 and from 1.0 to 1.8 respectively.

\section{DISCUSSION}

In comparable studies fractures are usually seen as a result of osteoporosis and implicitly referred to as 'osteoporotic fractures'. Obviously, patients with osteoporotic fractures need to be treated. In general practice, however, the majority of osteoporotic patients is not fractured. Furthermore, both the patient and her GP will often be unable to answer the question whether a fracture in the past had a causal relation with osteoporosis. We therefore decided to investigate a history of any fracture as one of the indicators of BMD rather than as a result of osteoporosis.

Almost one quarter of postmenopausal women above 50 were osteoporotic, whereas nearly two thirds of the women had low BMD. Since these women are at risk of developing osteoporotic fractures, this finding is of major importance both at the populational level and in daily general practice. In more detail table 6 shows that every postmenopausal woman with BMI $<27 \mathrm{~kg} / \mathrm{m}^{2}$ who had sustained any fracture during the past five years, or any postmenopausal woman with $\mathrm{BMI}<27 \mathrm{~kg} / \mathrm{m}^{2}$ without any fracture but age over 60 years, had an absolute risk of being osteoporotic or having low BMD which exceeded the mean prevalences for the study population. Using an algoritm with age, BMI and fracture history subgroups at high risk could be identified. However, in whatever combination, many women with osteoporosis could not be identified. This might justify BMD measurements in all 
women over 50 years of age, despite their age, BMI and fracture history. However, since this policy is not (yet) advocated in developed countries, in and outside Europe, it is preferable to concentrate BMD measurements on a subgroup of patients with a relatively high risk of having low BMD, and large enough to prevent fractures on a populational level. This subgroup might consits of women over 60 years of age, with low BMI and no history of fractures during the past five years. In this category of 1100 women 869 women $(79 \%)$ were found to have low BMD, and of these 869 women 407 were also osteoporotic. In the other categories additional clinical criteria, or additional methods, such as ultrasound measurements, or parameters of bone turnover ${ }^{(42)}$, may help to decide whether or not a BMD measurement should be considered, since in all other categories the presence of osteoporosis or low BMD is almost evident or less likely.

The detection of low BMD by performing DEXA measurement must always be related to the actual possibilities to intervene. Our finding that fractures play a key role in establishing BMD is in accordance with the results of a series of experimental studies which showed that the treatment of women who have suffered one fracture prevents the recurrence of hip and vertebral fractures ${ }^{(43-4)}$. It is particularly the GP who remains in contact with his patients for many consecutive years. He will always be informed when one of his patients suffers a fracture. Furthermore, the GP is familiar with the presence of co-morbidity and his patient's compliance with respect to previous interventions. Hence, the GP is the person to assess the possibility that osteoporosis or low BMD is present and at what moment an intervention should start.

From methodological point of view, our results cannot be adequately compared with those from previous studies in which BMD was measured with a DEXA. Studies with comparable size and design have differed considerably with regard to the recruitment of the participants. Study populations were either derived only from larger cities, or were selected with respect to age or from voter or vehicle registration lists ${ }^{(1-14)}$. Furthermore, BMD was sometimes measured at the hip or calcaneus, instead of at the lumbar spine. Finally, many reports of prevalences of osteoporosis do not meet the current WHO criteria ${ }^{(16)}$. The Rotterdam Study is by far the most comparable with the present study ${ }^{(12)}$. However, of the 11,854 inhabitants aged 55 years and over who were invited to participate, a selection of 678 men and 1084 women were entered into the cross-sectional analysis. Despite the differencies in methods, we found predictors for osteoporosis which were comparable with the results of other crosssectional studies, meaning that the first selection of patients at high risk for low BMD can be done adequately by both specialists and GPs. However, where others have emphasized the importance of an early menopause, the use of hormones, a family history of osteoporosis and co-morbidity as predictors or risk factors, our study found these characteristics to be of no more than additional value to the above mentioned four major predictors. 
The selection of independent variables took place on the basis of the results of previous relevant studies ${ }^{(1,6-11,15,16,22,48-54)}$. A previous study revealed that 'only women who had taken estrogen for 7 to 9 years or for 10 or more years had significantly higher bone mineral density than women who had not taken estrogen ${ }^{(55)}$. Our data show that women who used hormones for more than 5 years, actually used them for an average of approximately 10 years. It was therefore decided not only to dichotomise for the use of hormones, but also for the use of the pill, the cutoff point being five years.

The results in Table 3 and a comparison with data from registration networks of morbidity indicate that our study population is representative of a general population of women with comparable age in The Netherlands. The CBS-data do not provide standard deviations. Furthermore, the CBS-data were collected by interviewing members of the public, instead of measuring height and weight. Their means are thus slightly higher for height and lower for weight than ours ${ }^{(56,57)}$.

This study has several limitations. First, a bias could be introduced by the use of exclusion criteria. We therefore compared the subgroup 'excluded' women, (703 women out of 943 ) with the total study population. This subgroup showed mean values of BMD $\left(0.950 \mathrm{~g} / \mathrm{cm}^{2}\right)$, age (64 years), weight $(71 \mathrm{~kg})$, height $(162 \mathrm{~cm})$, and BMI $\left(27 \mathrm{~kg} / \mathrm{m}^{2}\right)$ similar to those of the total population. 'Presence of dissease' seemed little protective against osteoporosis, this needs further evaluation. Second, of the nonresponders to the invitation for participation $[(6264-4725) / 6246=24 \%], 118$ were on the registration list of the first author's practice. Of these 118 women, 19 could still be measured afterwards during a consultation with their GP. These 19 women showed mean values of BMD $\left(0,996 \mathrm{~g} / \mathrm{cm}^{2}\right)$, age (61 years), weight (71 $\mathrm{kg}$ ), height $(160 \mathrm{~cm})$ and BMI $\left(28 \mathrm{~kg} / \mathrm{m}^{2}\right)$ similar to those of the total study population; their slightly higher BMD was probably due to the lower mean age of this sample of nonresponders. Therefore, it is unlikely that the study results were biased in the sense of nonresponders being osteoporotic. Moreover, the compliance of all women finally invited was $100 \%$, which was to be expected since they had been informed by their own practice nurse (including as many telephone calls as necessary). In The Netherlands, such nurses have a close relationship with the patients registered with their GP. Third, this study is crosssectional and should be confirmed by a prospective study in GP setting, which is currently taking place. 
Figare 1 Flow chant

\begin{tabular}{|c|c|c|c|}
\hline 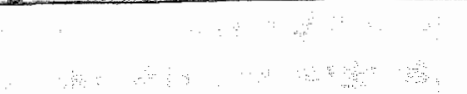 & $100 \%$ & \multicolumn{2}{|c|}{$\begin{array}{l}9107 \text { women aged } 50-80 \text { years } \\
\text { identified in } 12 \text { general practice centres. }\end{array}$} \\
\hline Identified by $23 \mathrm{GP}$ & & $\begin{array}{l}5303 \\
\text { postmenopausal } \\
\text { healthy women }\end{array}$ & $\begin{array}{l}3804 \\
\text { not-healthy womem }\end{array}$ \\
\hline Selected for participation & $69 \%$ & 5303 & $943(25 \%$ of 3804$)$ \\
\hline Invited & $69 \%$ & \multicolumn{2}{|c|}{6246} \\
\hline Participated $(76 \%$ of 6246$)$ & $52 \%$ & \multicolumn{2}{|c|}{4725} \\
\hline Informed consent obtained & & \multicolumn{2}{|c|}{4725} \\
\hline First four weeks, pilot study & 6 & \multicolumn{2}{|c|}{-516} \\
\hline DEXA measurement failed & & \multicolumn{2}{|c|}{-6} \\
\hline \multirow[t]{2}{*}{ Used for statistical analysis } & $46 \%$ & 3500 & 703 \\
\hline & $46 \%$ & \multicolumn{2}{|c|}{4203} \\
\hline
\end{tabular}

Table 1a. Description of the study population; non-discrete variables $(N=4203)$

\begin{tabular}{|l|cc|cc|}
\hline yariable & mean & $(\mathrm{SD})$ & median & $(\mathrm{Q} 1-\mathrm{Q} 3)$ \\
\hline BMD $\left(\mathrm{g} / \mathrm{cm}^{2}\right)$ & 0.925 & $(0.163)$ & 0.913 & $(0.811-1.023)$ \\
\hline age $($ years $)$ & 63 & $(7)$ & 62 & $(57-68)$ \\
\hline weight $(\mathrm{kg})$ & 71 & $(12)$ & 70 & $(63-78)$ \\
\hline height $(\mathrm{cm})$ & 161 & $(6)$ & 161 & $(157-165)$ \\
\hline BMI $\left(\mathrm{kg} / \mathrm{m}^{2}\right)$ & 27 & $(5)$ & 27 & $(24-30)$ \\
\hline fertile years & 34 & $(6)$ & 35 & $(30-38)$ \\
\hline pregnancies & 3 & $(2)$ & 3 & $(2-4)$ \\
\hline coffee consumptions/day & 5 & $(3)$ & 4 & $(3-6)$ \\
\hline alcohol consumptions/week & 6 & $(7)$ & 4 & $(2-7)$ \\
\hline smoking sigaretties/day & 14 & $(8)$ & 12 & $(9-20)$ \\
\hline years of smoking & 36 & $(11)$ & 37 & $(30-44)$ \\
\hline calcium intake & 874 & $(399)$ & 804 & $(598-1084)$ \\
\hline
\end{tabular}

Table 2. Prevalence of osteoporosis, stratified for age categonies.

\begin{tabular}{|c|c|c|c|c|c|c|}
\hline \multicolumn{7}{|c|}{ Study population of 4203 women age $50-80$ years. } \\
\hline age & $50-54$ & $55-59$ & $60-64$ & $65-69$ & $70-74$ & $75-80$ \\
\hline $\begin{array}{l}\text { number of } \\
\text { patients }\end{array}$ & 689 & 976 & 975 & 761 & 546 & 256 \\
\hline $\begin{array}{l}\text { mean BMD } \\
\mathrm{g} / \mathrm{cm}^{2} \text { (SD) }\end{array}$ & $0.99(0.16)$ & $0.94(0.16)$ & $0.90(0.15)$ & $0.90(0.16)$ & $0.91(0.17)$ & $0.89(0.18)$ \\
\hline $\begin{array}{l}\text { prevalence of } \\
\text { osteoporosis }\end{array}$ & $10 \%$ & $18 \%$ & $26 \%$ & $29 \%$ & $30 \%$ & $38 \%$ \\
\hline
\end{tabular}


Tabel $1 \mathrm{~b}$. Description of the study population; discrete variables $(\mathrm{N}=4203)$

\begin{tabular}{|l|cc|}
\hline & Answer "Yes" \\
\hline variable & \multicolumn{3}{|c|}{} \\
\hline low back pain & 1858 & $(45 \%)$ \\
\hline fractures during past 5 years & 344 & $(8 \%)$ \\
\hline presence of disease & 1878 & $(45 \%)$ \\
\hline use of the pill $>5$ years & 610 & $(15 \%)$ \\
\hline use of hormones $>5$ years & 232 & $(6 \%)$ \\
\hline ovariectomy & 571 & $(14 \%)$ \\
\hline hysterectomy & 1329 & $(32 \%)$ \\
\hline menopause under the age of 45 & 1186 & $(29 \%)$ \\
\hline perimenopausal complaints & 1031 & $(25 \%)$ \\
\hline family history of osteoporosis & 424 & $(10 \%)$ \\
\hline coffee 'user' & 3936 & $(94 \%)$ \\
\hline alcohol 'user' & 1483 & $(36 \%)$ \\
\hline tobacco 'user' & 1108 & $(27 \%)$ \\
\hline occupational exercise in the past, & 534 & 3432 \\
\hline 3 categories & mild & moderate \\
& $13 \%$ & $83 \%$ \\
\hline sports at present & 1427 & $(34 \%)$ \\
\hline sports in the past & 1526 & $(37 \%)$ \\
\hline
\end{tabular}

Table 3.External validity of the study population. Mean values for age, weight, height and BMII, including standard deviations (SD), found in several important epidemiological surveys in The Netherlands, ${ }^{(12,36,37)}$

\begin{tabular}{|c|c|c|c|c|c|c|}
\hline & & $\begin{array}{l}\text { Studypopulation } \\
(1993-94)\end{array}$ & $\begin{array}{l}\text { Rotterdam } \\
\text { study (1993) }\end{array}$ & $\begin{array}{l}\text { TNO report } \\
\text { (1988) }\end{array}$ & $\begin{array}{l}\text { CBS } \\
(1990-93) \\
\text { country }\end{array}$ & $\begin{array}{l}\text { CBS } \\
(1993-95) \\
\text { province }\end{array}$ \\
\hline \multirow[t]{2}{*}{ Age } & & $50-80$ & $55-85$ & $70-80$ & $50-80$ & $50-80$ \\
\hline & $\therefore$ & $n=4203$ (SD) & $n=1084(\mathrm{SD})$ & $\mathrm{m}=174(\mathrm{SD})$ & $\mathrm{n}=5029(\mathrm{z})$ & $n=345(*)$ \\
\hline \multirow[t]{2}{*}{$50-80$} & weight & (13) & $70 \quad$ (11) & & 69 & 68 \\
\hline & height & 161 & $161 \quad(6)$ & & 165 & 164 \\
\hline \multirow[t]{2}{*}{$50-59$} & weight & (13) & & & 69 & 70 \\
\hline & height & 162 & & & 166 & 165 \\
\hline \multirow[t]{2}{*}{$60-69$} & weight & $(12)$ & $71 \quad(12)$ & & 70 & 68 \\
\hline & height & 161 & $163 \quad(6)$ & & 166 & 163 \\
\hline \multirow[t]{3}{*}{$70-80$} & weight & (12) & 69 (11) & $69 \quad(11)$ & 67 & 66 \\
\hline & height & 159 & $160 \quad(6)$ & $160 \quad$ (6) & 164 & $\$ 63$ \\
\hline & BMI & $27.7 \quad(4)$ & $27.2(4)$ & $27.0(4)$ & 25.1 & 25 \\
\hline
\end{tabular}

(*) no standard deviations available. 
Table 4. Results of mulltiwatiable logittic regression analysis for all variables: oddsratios and their $95 \%$ confidence interval $(\mathrm{N}=4203)$

\begin{tabular}{|c|c|c|}
\hline & $\begin{array}{c}\text { Osteoporosis } \\
\left(\mathrm{BMD}<0.800 \mathrm{~g} / \mathrm{cm}^{2}\right)\end{array}$ & $\begin{array}{c}\text { Low bone mass } \\
\left(\mathrm{BMD}<0.970 \mathrm{~g} / \mathrm{cm}^{2}\right)\end{array}$ \\
\hline $\begin{array}{l}\text { Hosmier-Lemeshow goodness-of-fit test } \\
(\mathrm{p} \text {-value) }\end{array}$ & $6209 \quad(0.624)$ & $3229 \quad(0.919)$ \\
\hline Independent variable, cut-point & (ci) & OR $\quad(\mathrm{c} i)$ \\
\hline age, over 60 years & $(2.09-3.06)$ & $(1.48-2.01)$ \\
\hline weight, under $70 \mathrm{~kg}$ & $(1.51-2.44)$ & $(1.52-2.29)$ \\
\hline height, under $160 \mathrm{~cm}$ & $(1,23-1.74)$ & $(1.13-1.54)$ \\
\hline BM, under $27 \mathrm{~kg} / \mathrm{m}^{2}$ & $(1.40-2.23)$ & $(1.20-1.79)$ \\
\hline presence of low back pain. & $(0.82-1.13)$ & $(0.95-1.26)$ \\
\hline fractures during past 5 years & $(1,40-2,35)$ & $(1,37-2,39)$ \\
\hline presence of disease & $(0.68-1.03)$ & $(0.74-1.06)$ \\
\hline use of the pill less than 5 years & $(0.65-1.07)$ & $(0.69-1.02)$ \\
\hline use of hormones less than 5 years & $(1.16-2.83)$ & $(1.43-2.61)$ \\
\hline ovariectomy in history & $(0.72-1.24)$ & $(1.05-1.65)$ \\
\hline bysterectomy in history & $(0.65-1.00)$ & $(0.62-0.89)$ \\
\hline menopause under the age of 45 & $(0.89-1.36)$ & $(0.85-1.26)$ \\
\hline less than 35 fertile years & $(1.11-1.63)$ & $(1.18-1.66)$ \\
\hline mote than 2 children & $(0.83-1.15)$ & $(0.87-1.15)$ \\
\hline perimenopausal complaints in history & $(0.76-1.13)$ & $(0.78-1.09)$ \\
\hline positive family history of osteoporosis & $(1.14-1.90)$ & $(1.09-1.76)$ \\
\hline coffee intake & $(1.00-2.11)$ & $(0.63-1.20)$ \\
\hline alcohol intake & $(0.79-1.12)$ & $(0.86-1.15)$ \\
\hline smoking & $(0.77-1.12)$ & $(0.88-122)$ \\
\hline calcium intake, less than $500 \mathrm{mg}$ & $(0.88-1.36)$ & $(0.90-1.34)$ \\
\hline $\begin{array}{ll}\text { occupational, } & \text { mild } \\
\text { exercise, } & \text { moderate } \\
3 \text { categories, } & \text { heavy } \\
\end{array}$ & $\begin{array}{ll}1.02 & (0.80-1.31) \\
1.55 & (1.01-2.39)\end{array}$ & $\begin{array}{ll}1.07 & (0.86-1.33) \\
1.08 & (0.73-1.61)\end{array}$ \\
\hline no sports at present & $(0.78-1,10)$ & $(0.86-1.16)$ \\
\hline no sports in the past & $(0.73-1.04)$ & $(0.80-1.07)$ \\
\hline
\end{tabular}


Table 5. Results of multivariable logistic regression analysis, final model:odds ratios and their $95 \%$ confidence interval $(\mathrm{N}=4203)$.

\begin{tabular}{|c|c|c|}
\hline$\because:$ & $\begin{array}{c}\text { Osteoporosis } \\
\left(\mathrm{BMD}, 0.800 \mathrm{~g} / \mathrm{cm}^{2}\right)\end{array}$ & $\begin{array}{l}\text { Low bone mass } \\
\left(\mathrm{BMD}<0.970 \mathrm{~g} / \mathrm{cm}^{2}\right)\end{array}$ \\
\hline $\begin{array}{l}\text { Hosmer-Lemeshow goodness-of-fit test } \\
\text { (p-value) }\end{array}$ & $5119 \quad(0.745)$ & $7313 \quad(0.503)$ \\
\hline Independent variable, cutt-point & $(c . i)$ & $\mathrm{OR}$ (e.1) \\
\hline age, over 60 years & $2.70 \quad(2.23-3.28)$ & $1.77 \quad(1.52-2.05)$ \\
\hline weight, under $70 \mathrm{~kg}$ & $(1.48-2.39)$ & $1.84 \quad(1.51-2.26)$ \\
\hline height, under $160 \mathrm{~cm}$ & - & - \\
\hline BMI, under $27 \mathrm{~kg} / \mathrm{m}^{2}$ & $(1.40-2.22)$ & $(1.23-1.83)$ \\
\hline fractures during past 5 years & $(2.13-6.08)$ & $(1.78-4,57)$ \\
\hline presence of disease & $(0.68-0.95)$ & $(0.72-0.95)$ \\
\hline use of hormones less than 5 years & - & $(1.05-2.14)$ \\
\hline hysterectomy in history & $(0.67-0.97)$ & $0.82 \quad(0.70-096)$ \\
\hline less than 35 fertile years & $(1.19-1.68)$ & $(1.28-1.74)$ \\
\hline positive family history of osteoporosis & $(1.13-1.87)$ & $(1.09-1.77)$ \\
\hline occupational exercise, moderate & $(1.07-2.50)$ & - \\
\hline
\end{tabular}

Table 6a. Multivariable model of 3 risk factors for osteoporosis in the study population: absolute risks and realtive risks of osteoporosis are given. All combinations are compared with reference category $3 \times N O$. Prevalence of osteoporosis $23 \%,(n=4203)$.

\begin{tabular}{|c|c|c|c|c|c|}
\hline $\begin{array}{l}\text { fractures during the } \\
\text { past } 5 \text { years }\end{array}$ & age & BMI & n & $\begin{array}{l}\text { absolute risk for } \\
\text { osteoporosis }\end{array}$ & $\begin{array}{l}\text { relative risk for } \\
\text { osteoporosis }\end{array}$ \\
\hline YES/NO & $60+$ & $<27$ & & & \\
\hline \multirow[t]{4}{*}{ YES } & \multirow[t]{2}{*}{ MES } & YES & 132 & $51 \%$ & 57 \\
\hline & & NO & 114 & $22 \%$ & 24 \\
\hline & \multirow{2}{*}{ NO } & YES & 54 & $37 \%$ & 41 \\
\hline & & NO & 48 & $17 \%$ & 1.9 \\
\hline \multirow[t]{4}{*}{ NO } & \multirow[t]{2}{*}{ YES } & YES & 1100 & $37 \%$ & 41 \\
\hline & & NO & 1194 & $19 \%$ & 2.1 \\
\hline & \multirow[t]{2}{*}{ NO } & YES & 917 & $17 \%$ & 1.9 \\
\hline & & NO & 644 & $9 \%$ & 1.0 \\
\hline
\end{tabular}

Table 6b. Multivariable model of 3 risk factors for low $\mathrm{BMD}$ in the study population: absolute risks and relative risks are given. All combinations are compared with reference category $3 \times$ NO. Prevallence of low $\mathrm{BMD} 65 \%(\mathrm{n}=4203)$.

\begin{tabular}{|c|c|c|c|c|c|}
\hline $\begin{array}{l}\text { fractures during the } \\
\text { past } 5 \text { years }\end{array}$ & age & BMI & n & $\begin{array}{l}\text { absolute risk for } \\
\text { low BMD }\end{array}$ & $\begin{array}{l}\text { relative risk } \\
\text { for low BMD }\end{array}$ \\
\hline YES/NO & $60+$ & 27 & & & \\
\hline \multirow[t]{4}{*}{ YES } & \multirow[t]{2}{*}{ YES } & YES & 132 & $84 \%$ & 1.8 \\
\hline & & NO & 114 & $74 \%$ & 15 \\
\hline & \multirow[t]{2}{*}{$\mathrm{NO}$} & YES & 54 & $78 \%$ & 1.6 \\
\hline & & $\mathrm{NO}$ & 48 & $65 \%$ & 14 \\
\hline \multirow[t]{4}{*}{ NO } & \multirow[t]{2}{*}{ YES } & YES & 1100 & $79 \%$ & 1.6 \\
\hline & & NO & 1194 & $59 \%$ & 12 \\
\hline & \multirow[t]{2}{*}{ No } & YES & 917 & $63 \%$ & 1.3 \\
\hline & & NO & 644 & $48 \%$ & 1.0 \\
\hline
\end{tabular}




\section{RETERENCES}

1. Riggs BL, Melton LJ. The worldwide problem of osteoporosis: Insights afforded by epidemiology. Bone 1995; 17:505:511s

2. De Laet C, Van Hout BA, Pols HAP. Osteoporosis in The Netherlands. Institute for Medical Technology Assessment. MTA report 96.44. Rotterdarn: iMTA, 1996

3. Boereboon FTI, De Groot RRM, Raymakers JA, Duursma SA. The incidence of hip fractures in The Netherlands. Neth J Med 1991;38:51-58

4. Boereboom FT, Raymakers IA, Durursma SA. Mortality and disability after hipfractures in The Netherlands. In: Durursma SA, Raymakers JA, Scheven BAA. Update on osteoporosis 25 jagr boten calciumresearch in Utrecht. Utrecht: Stichting education permanente, 1990 (17-24)

5. Stevenson. JC, Lees B, Davenport M, Cust MP, Ganger KF. Determinants of bone density in normal women: risk factors for future osteoporosis? $\mathrm{Br}$ Med $\mathbb{J} 1989 ; 298: 924-28$

6. Cummings SR, Niewitt MC, Brownet WS, Stone H, Fox K, Ensrud KE, et al. Risk factors for hip fracture in white women. N Engl J Med 1995;332:767-73

7. Hanssen MA, Overgaard K, Rüis BJ, Christiansen C. Potential risk factors for development of postmenopausal osteoporosis: examined over a 12-year period. Osteoporosis Int 1991;1:95-102

8. Elliot JR, Ayling E, Gilchrist NL, Turner J, Wells JE, Sainsbury R. Historical assesment of risk factors in screening for osteopenia in normal Caucasian population. Aust NZ J Med 1993;23:458-62

9. Bauet DC, Brouwner WS, Cauley JA, Orwoll ES, Scott JC, Black DM, et al. The Study of Osteoporotic Fractures Research Group. Factors associated with appendicular bone mass in older women. Ann Intern Med 1993;118:657-65

10. Marshall $\mathrm{D}_{\mathrm{y}}$ Johnell $\mathrm{O}$, Wedel H. Meta-analysis of how well measures of bone mineral density predict occurrence of osteoporotic fractures. Br Med J 1996;312:1254-59

11. Cummings SR, Kelsy IL, Nevitt MC, O'Dowd KJ. Epidemiology of osteoporosis and osteoporotic fractures. Epidemiologic Reviews 1985;7:178-209

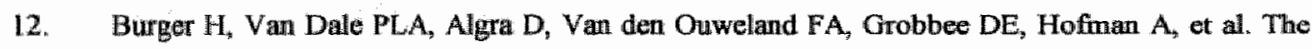
association between age and bone mineral density in men and women aged 55 years and over. The Rotterdam Study. Bone Miner 1994;25:1-113

13. Orwoll ES, Bawer DC, Vogt TM, Fox KM. Axial bone mass in older women. Ann Int Med $1996 ; 124: 187-96$

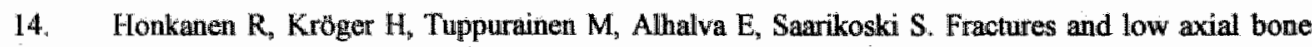
density in perimenopausal women. J Clin Epidemiol 1995;48:881-88

15. Melton LJ III, Chrischilles EA, Lane AW, Riggs BL. How many women have osteoporosis? J Bone Miner Res 1992;9:1005-10

16. Kanis JA. Textbook of osteoporosis. Oxford: Blackwell Science, 1996

17. Assessment of fracture risk and its application to screening for postmenopausal osteoporosis. Geneva: WHO Technical report series 843, 1994

18. Mcknight $A$ Steele $K$, Gilchrist $C$, Taggart $H$. Bone mineral density in relation to medical and lifestyle risk-factors for osteoporosis in premenopausal, menopausal and postmenopausal women in general practice. Br J Gen Pract 1995;45:317-20 
19. Delmas PD. Diagnostic procedures for osteoporosis in the elderly Horm Res 1995;43:80-82

20. Anonymous. Clinical practice guidelines for the diagnosis and management of osteoporosis. Can Med Assoc J 1996;155:1113-33

21. Daly PA. Office management of osteoparosis: a guide for the primary care provider. Comprehensive Therapy 1995;21:565-74

22. Cooper $\mathrm{C}$, Shah $\mathrm{S}$, Hand $\mathrm{DJ}$, Adams J, Compston $\mathrm{J}_{\mathrm{s}}$ Davie $\mathrm{M}_{s}$ et al. Screening for vertebral osteoporosis using individual risk factors. Osteoporosis Int 1991;2:48-53

23. Matkovic V, Jelic T, Wardlaw GM, 1lich JZ, Goel PK, Wright JK, et al "Timing of peak bone mass in Caucasian females and its implications for the prevention of osteoporosis. $J$ Clin Invest 1994;93:799-808

24. Miller PD, Bonnick SL, Rosen CJ. Consensus of an international panel on the clinical utility of bone mass measurements in the detection of low bone mass in the adult population. Calcif Tissue Int 1996; 58:207-14

25. Compston JE, Cooper C, Kanis JA. Bone densitometry in clinical practice. Br Med J 1995;310:150710

26. Wahner HW, Fogelman I. The evaluation of osteoporosis: Dual energy X-ray absorptiometry in clincal practice. Cambridge: University Press, 1994

27. Hailey D. INAHTA project on bone density measurements and treatments for osteoporosis. Background paper 1. Methods used in the measurement of bone density. Edmenton: Alberta Heritage Foundation for Medical Research, 1996

28. ITS-Beroepenklapper. The Netherlands Institute of Applied Social Studies.

29. Stafleu A, Burema J, Hulshof KFAM, Van Staveren WA. Reproduceerbaarheid van een vragenlijst naar de calcium- en vitamine D-inneming. Tijdschr Soc Gezondheidsz [Abstract in English] $1989 ; 67: 370-74$

30. Van Staveren WA. Food intake measurements: their validity and reproducibility. Wageningen: Landbouwuniversiteit, 1985

31. ONeill TW, Cooper $C_{3}$ Cannata JB, Diaz Lopez JB, Hoszowiski $K_{v}$ Johnell $\mathrm{O}$, et al. Reproducibility of a questionnaire on risk factors for osteoporosis in a multicentre prevalence survey: The European Vertebral Osteoporosis Study. Int J Epidemiol 1994;23:559-65

32. Mannisto $S$, Virtanen $M$, Mikkonen $T$, Pietinen $P$. Reproducibility and validity of a food frequency questionnaire in a case control study on breast cancer. J Clin Epidemiol 1996;49:401-9

33. Dixon $W_{j}$, Brown MB, Engelman L, Holl MA, Jenrich RI. BMDP statisticall software manual. Berkeley: University of California Press, 1990

34. Bone Density Reference Data. Bruxelles: S.A. Hologic Europe.

35. Steiger $\mathrm{P}$, Cummings $\mathrm{SR}$, Black DM, Spencer NE, Genant HK. Age-related decrements in bone mineral density in women over 65. J Bone Miner Res 1992,7:625:32

36. Age and antropometric variables among dutch elderly men and women. Zeist: Institute CIVOToxicologie, 1988

37. Statistisch Jaarboek 1995, s'Gravenhage: Centraal bureau woor de statistiek, 1995 
38. Van de Lisdonk EH, Van den Bosch WJM, Hurygen FJA, Lagro-Jansen ALM. Ziekten in de Huisartspraktijk. Utrecht: Bunge, 1990

39. Metsemakers JFM, Höppener P, Knottnerus JA, Kocken RJ, Liomonard CBG. Computerize health information in The Wetherlands: a registration network of family practices. Br J Gen Pract 1992; 42:102-6

40. Lamberts H, Wood M ICPC: International Classification of Primary Care. Oxford: University Press, 1987

41. Hosmer DW, Lemeshow S. Applied logistic regression. New York: Wiley; 1989

42. Wilkin TJ. Changing perceptions in osteoporosis. BMJ 1999;318:862-5

43. Wasnich R. Bone miass measurement: prediction of risk Am J Med 1993;95(supplA):6s-10s

44. Ross $\mathrm{PD}_{2}$ Genant HK, Davis JW, Miller PD, Wastich RD. Predicting wertebral fractures incidence from prevalent fractures an bone mineral density among non-black, osteoporotic women. Osteoporosis Int 1993;3:120-26

45. Black DM, Cummings SR, Karpf DB, Cauley JA, Thompson DE, Nevitt MC, et al Randlomised trial of effect of alendronate on risk of fracture in women with existing vertebral fractures. Lancet $1996,348: 1535-41$

46. Liberman, UA, Weiss SR, Bröll. JB, Minne HW, Quan $\mathrm{H}_{3}$, Bell $\mathrm{NH}_{3}$ et all. Effect of alendronate on bone mineral density and the incidence of fractures in postmenopausal osteoporosis. N Engl J Med $1995 ; 333: 1437-43$

47. Papapoulos SE, Lockefeer JHM. Bisfosfonaten bij osteoporosis; een herbeoordeling. Ned Tijdschr Geneeskd 1996;140:2394-98

48. Johnston CC, Slemenda CW. Risk assessment: Theoretical considerations. Am J Med 1993;95(suppl $5 A): 2 s-5 s$

49. Krall EA, Dawson-Hughes B. Heritable and lifstyle determinants of bone mineral density. J Bone Miner Res 1993,8:1-9

50. Slemenda CW. Cigarettes and the skeleton. N Engl J Med 1994;330,430-31

51. Heaney RP. Bone mass, nutrition and other lifestyle factors. Am J Med 1993;95(suppl 5.A):29s-33s

52. Holbrook TL, Barrett-Connor E. A prospective study of alcohol consumption and bone mineral density. BrMed J 1993;306:1507-9

53. Felson DT, Zhang $\mathrm{Y}$. Alcohol intake and bone mineral density in elderly men and women. The Framingham study. Am J Epideniol 1995;142:485-92

54. Melton LJ, Eddy DM, Johnston CC. Screening for osteoporosis. Ann Int Med 1990;1 12:517-28

55. Felson DT, Zhang Y, Hannan MT, Kiel DP, Wilson PW, Anderson JJ. The effect of postmenopausal estrogen therapy on bone density in elderly women. N Engl J Med 1993;329:1141-46

56. Kuskowska-Wolk A, Bergstrom R, Bostrom $\mathrm{G}$. Relationship between questionnaire data and medical records of height, weight and body mass index. Int J Obes Relat Metab Disord 1992;16:1-9

57. Jalkanen $L$, Tuomilehto $J_{y}$ Tanskanen $A$, Puska $P$. Accuracy of selfreported body weight compared to measured body weight. Scand J Soc Med 1987; 15:191-98 


\subsection{Samenvatting}

Doel van de studie: een algoritme maken om snel patiènten met een lage botmineraaldichtheid (BMD) of osteoporose te kunnen detecteren en om te bepalen wat de bruikbaarheid ervan is in de dagelijkse huisartspraktijk.

Studie design. Het is een cross-sectionele studie onder alle 9107 , in 12 huisartspraktijken ingeschreven, postmenopauzale vrouwen van 50-80 jaar.

Patiènten en methoden. Alle gezonde vrouwen (5303) en $25 \%$ van de resterende groep (943/3804) werden uitgenodigd voor deelname aan het onderzoek. Van de 6246 uitgenodigde vrouwen deden er $4725(76 \%)$ mee. Er werd een algemene anamnese afgenomen (betreffende de gezondheidstoestand, de medische voorgeschiedenis en het familiair voorkomen van osteoporose) en er werd een voedingsanamnese afgenomen. Van alle vrouwen werden gewicht en lengte gemeten en werd de BMD van de lumbale wervelkolom bepaald. Statistiek. Multivariabele logistische regressie analyses werden verricht met de BMD van de lumbale wervelkolom als afhankelijke variabele $\left(\mathrm{L} 2-4\right.$, afkappunten $0,800 \mathrm{gr} / \mathrm{cm}^{2}$ voor osteoporose en $0,970 \mathrm{gr} / \mathrm{cm}^{2}$ voor een lage BMD). Het algoritme werd gemaakt met die variabelen, die statistisch significant en klinisch relevant correleerden met de aanwezigheid van zowel osteoporose als een lage BMD.

Resultaten. De prevalentie van osteoporose was $23 \%$, die van een lage BMD was $65 \%$. Slechts drie variabelen (leeftijd, BMI en recente fracturen) waren statistisch significant en klinisch relevant gecorreleerd met de aanwezigheid van osteoporose en een lage BMD. Leeftijd (OR 2,70 voor osteoporose en OR 1,77 voor een lage BMD) en fracturen gedurende de laatste vijf jaar (OR 3,60 voor osteoporose en OR 2,85 voor een lage BMD) bleken de belangrijkste voorspellers. Het algoritme toonde een absoluut risico voor osteoporose, welke varieerde van $9 \%$ tot $51 \%$ en een absoluut risico voor een lage BMD, welke varieerde van $48 \%$ tot $84 \%$. De corresponderende relatieve risico's varieerden van 1,0 tot 5,7 en van 1,0 tot 1,8 .

Conclusies. Gebruikmakend van een algoritme met leeftijd, BMI en recente fracturen kunnen subgroepen met een hoog risico voor osteoporose en een lage BMD wörden geïdentificeerd. Welke combinatie we echter maken, toch kunnen veel vrouwen met osteoporose niet worden geidentificeerd. Ondanks de aanwezige verschillen in onderzoeksmethoden vonden we voorspellers voor osteoporose die vergelijkbaar waren met de resultaten van andere crosssectionele studies. Dat betekent dat de eerste selectie van patiënten met een hoog risico voor een lage BMD door zowel specialisten als huisartsen adequaat kan worden gedaan. 
Hoofdstuk 4 


\section{Hoofdstuk 4}

Screening for osteoporosis using easily obtainable biometrical data: diagnostic accuracy of measured, self-reported and recalled BMI, and related costs of bone mineral density measurements.

1. D.J.M. van der Voort, $\mathrm{MD}(1)$

2. S. Brandon, $\mathrm{MD}(1)$

3. G.J. Dinant, $\mathrm{MD}, \mathrm{PhD}(1)$

4. J.W.J. van Wersch, $\mathrm{PhD}_{3}$ clinical chemist (2)

(1): University Maastricht, Department of General Practice and Research Institute for Extramural and Transmural Health Care, Maastricht, Netherlands

(2): Department of Clinical Chemistry, De Wever Hospital, Heerlen, Netherlands

Published in Osteoporosis International 2000;11:233-239 


\section{ABSTRACT}

Objective: To determine the diagnostic accuracy of objectively measured, self-reported and recalled body mass index (BMI) for osteoporosis and osteopenia; to determine the diagnostic costs, in terms of bone mineral density (BMD) measurements, per osteoporotic or osteopenic patient detected, using different BMI tests; and to determine the extent to which the results can be used within the framework of the current screening program for breast cancer in The Netherlands:

Methods: Within the framework of a cross-sectional study on the prevalence of osteoporosis in the south of The Netherlands, 1155 postmenopausal women aged $50-80$ years were asked for their present height and their weight at age $20-30$ years. Subsequently their actual weight, height and BMD of the lumbar spine (DEXA) were measured. The BMD cutoff was 0.800 for osteoporosis and 0.970 for low BMD (osteoporosis + osteopenia). After receiving operating characteristic analysis, age was cut off at 60 years and BMI at $27 \mathrm{~kg} / \mathrm{m}^{2}$. Diagnostic accuracy of objectively measured, self-reported and recalled BMI were evaluated using predictive values (PV) and odds ratios. The resulting true positive' and 'false positive' rates were used to calculate diagnostic costs (i.e. DEXA) for each osteoporotic or low-BMD patient detected.

Results: The prevalence of osteoporosis in the study population was $25 \%$, that of low BMD $65 \%$. Only the age-BMI tests 'age $\geq 60$, BMI $\leq 27$ ' showed PVs for osteoporosis $(31 \%-41 \%)$ and for low BMD $(71 \%-81 \%)$ which were higher than the prior probabilities for these conditions. Related odds ratios were $2.14-3.18$ (osteoporosis) and $1.87-3.04$ (low BMD). The objective BMI test detected $50 \%$ of the osteoporotic patients. Using the self-reported BMI test and the recalled BMI test, detection rates increased to $55 \%$ and $69 \%$ respectively. Concomitant costs per osteoporotic patient detected rose by $24 \%$. Detection of patients with a low BMD increased from $38 \%$ for objective BMI and $42 \%$ for self-reported BMI to $60 \%$ for recalled BMI. Related costs increased by $11 \%$. In case all women over 50 years of age (irrespective of their BMI) were to be referred for BMD measurement, costs per osteoporotic patient or low-BMD patient detected would be 304 and 116 Euros respectively.

Conclusions: Only in women over 60 years does a BMI below $27 \mathrm{~kg} / \mathrm{m}^{2}$ provide a better prediction of the presence of osteoporosis or low BMD than could be expected solely on the basis of the relevant prevalences in postmenopausal women aged 50-80 years. If the use of BMl for the detection of osteoporotic or low-BMD patients is still considered, measuring weight and just asking for a person's height will do. Although age and BMI are the strongest risk factors for osteoporosis, they are of less significance when used for screening the population for osteoporosis. More research is needed before age and BMI can be included in any screening program. As regards practical considerations alone, measurements of $\mathrm{BMD}$ could be implemented within the screening program for breast cancer. 


\section{INTRODUCTION}

In most countries information on public health is acquired by means of self-administered questionnaires. These statistical data are used directly in government policy on public health. Unfortunately, self-reported data are not always accurate. Several validity studies have reported 'self-image' bias to lead to false estimates of important health issues; such as overweight and obesity ${ }^{(1-6)}$.

Previous studies on self-reported height and weight compared with actual measurements have concluded that height is often overestimated and weight is often underestimated ${ }^{(1-8)}$. Alhough the differences between self-reported data and actual measurements are small, they seem to result in an underestimated prevalence of overweight and obesity according to body mass index (BMI) categories ${ }^{(1-\theta)}$. Most studies conclude that the self-reported bias allso depends on sex and age. Older women report overestimated height and underestimated weight, whereas men provide more reliable information ${ }^{(1,3,4,5,7)}$. Previous studies of recalled weight have described a reasonable accuracy of recalled weight in young as well as in elderly populations, even with a large time gap (28-50 years) ${ }^{(9-12)}$. Recalled weight bias is largely associated with the BMI category around the time recalled. Obese individuals tend to underestimate their past weight, while slender subjects overestimate it. Current BMI category seems to have little influence on the direction and proportion of recalled weight error ${ }^{(12)}$. A comparison of several studies shows that bias in self-reporting of anthropometric measures depends on factors such as demographic, cultural, social and educational differences ${ }^{(3,4,7,8,12)}$.

These conclusions indicate that a comparison between self-reported and objectively measured data is useful with respect to the presence of risk factors for frequently occurring diseases, such as osteoporosis. It is known that a high BMI reduces the probability of osteoporosis being present. On the basis of the above literature results, it can thus be expected that, in screening for osteoporosis, the use of self-reported biometrical data will result in a larger percentage of the population being suspected of having the condition than will the use of objectively measured weight and height. Hence, if self-reported biometrical data are used for the selection of patients indicated for a radiological measurement of bone mineral density (BMD), a higher proportion of the population will be referred. Consequentlly, costs per patient detected will rise.

The effects of preventive strategies (at the population level and, more importanily, at the individual level), as well as the results of drug intervention studies stimulate the idea that screening for osteoporosis is useful ${ }^{(13,14,15)}$ However, lack of evidence on the longterm effect of bone-preserving drugs, in terms of preventing fractures, justifies the proposition that screening should be limited to postmenopausal women with additional risk factors, such as low BMI. It would be very welcome if this screening could be implemented within existing programs, 
thereby limiting efforts and costs as much as possible. The current screening program on breast cancer in The Netherlands might be a good example. In this program women between 50 and 75 years of age are examined by radiography on a five-yearly basis.

Within the framework of a cross-sectional study on the prevalence of osteoporosis and related risk factors in postmenopausal women aged 50 - 80 years, data were collected on weight and height, and on self-reported height. The women were also asked to recall their weight at the age of 20 - 30 years. With the help of these parameters, different 'BMI tests' were constructed, which were then used to try and answer the following questions. (1) What is the diagnostic accuracy of objectively measured, self-reported and recalled BMI (including the difference between recalled and objectively measured BMI) for osteoporosis and osteopenia. (2) What are the diagnostic costs, in terms of BMD measurements, per osteoporotic or osteopenic patient detected, using different BMI tests, and what is the relationship between diagnostic costs and the numbers of undetected osteoporotic or osteopenic patients. (3) To what extent can the results be used within the framework of the current screening program on breast cancer in The Netherlands?

\section{METHODS}

\section{Population}

Between October 1992 and March 1994, 23 general practitioners (GPs) in 12 practice areas, all located in the south-east of The Netherlands, recruited the study population. As has been described previously, of a total population of 9107 women, 6246 women were invited to participate. Of the 6246 invited subjects, 4725 postmenopausal women participated in the study ${ }^{(16)}$. These were asked to complete a questionnaire containing a subsection on recalled weight at age 20-30 years. Immediately after completion of the questionnaire, actual weight, height and BMD were measured. At the beginning of the visit, informed consent was obtained from all 4725 participants.

\section{Measurements}

Weight was measured in $\mathrm{kg}$, using one Seca scale, to the nearest 500 grams, with one outer layer of clothes and without shoes. The Seca scale was calibrated monthly. Height was measured in centimeters, without shoes, with both heels and the back against the wall, using one wallmounted centimeter scale. BMD of the lumbar spine was measured with one computer guided DEXA instrument (Hologic QDR-1000, Hologic Europe, Brussels, Belgium), located in the first author's practice ${ }^{(16-20)}$. The instrument was calibrated daily by one research nurse, using a phantom and a computer guided standard procedure. If necessary, measurements were interrupted until Hologic technicians had adjusted the instrument on the same day. The results of the measurements are given as the mean BMD (in $\mathrm{g} / \mathrm{cm}^{2}$ ) of L2-LA. In those cases where 
measurements failed, the investigator immediately checked for any abnormalities that might be interfering with osteoporosis, e.g. substantial scoliosis or excessive osteophytesis These patients were excluded from the data analysis. All measurements were performed by four experienced and specially trained research nurses, and assessed by the investigator and a specialist on BMD measurements. To correct for possible imprecisions, a series of measurements was done twice. During the study period, the four research nurses attended four interobserver reliability sessions.

\section{Statistics}

Since data collection on recalled weight at age 20-30 years started a few months after the onset of the study, the recalled BMI could be calculated in $24.4 \%$ of the population (1155 patients). Further data analysis was performed for this population. For the statistical analysis the BMDP. program was used ${ }^{(21)}$ BMD values (dependent variable) were dichotomized at $0.80 \mathrm{~g} / \mathrm{cm}^{2}$ (for osteoporosis) and $0.97 \mathrm{~g} / \mathrm{cm}^{2}$ (for osteopeniatosteoporosis = low BMD). The cutoff points corresponded to 2.5 and 1 standard deviations below the mean BMD of L2-LA, measured in a healthy adult female population aged 30 years, using the Hologic QDR-1000 $22,23,24)$.

BMI was estimated in three different ways: 1. objective BMI [ $=$ measured weight/(measured height $\left.)^{2}\right], 2$. self-reported BMI [= measured weight/(self-reported height) $\left.{ }^{2}\right] ; 3$. recalled BMI [= recalled weight at age $\left.20-30 /(\text { self-reported height })^{2}\right]$. Optimal cutoff points for the three BMI tests (highest values for the sum of sensitivity and specificity) and age were determined by entering these variables into receiver operating characteristic (ROC) analyses. The cutoff point for BMI was found to be $27 \mathrm{~kg} / \mathrm{m}^{2}$, while that for age was 60 years.

The corresponding sensitivities, specificities (and 95\% confidence intervals) for BMI were:

- osteoporosis: sensitivity $=68 \%(65 \%-71 \%)$, specificity $=52 \%(50 \%-54 \%)$;

- low BMD : sensitivity $=59 \%(57 \%-61 \%)$, specificity $=59 \%(57 \%-61 \%)$;

and for age:

- osteoporosis: sensitivity $=75 \%(73 \%-78 \%)$, specificity $=44 \%(42 \%-46 \%)$,

- low BMD : sensitivity $=65 \%(63 \%-67 \%)$, specificity $=48 \%(45 \%-50 \%)$.

This resulted in four combinations: age $<60, \mathrm{BMI}>27$; age $\geq 60, \mathrm{BMI}>27$, age $<60, \mathrm{BMI} \leq 27$ and age $\geq 60, \mathrm{BMI} \leq 27$. The first combination can be expected to have a relatively small predictive value for low $B M D$, while the last combination should have a relatively high P.V. for low $\mathrm{BMD}$. The four combinations of BMI and age and the three BMI tests resulted in 12 age-BMI tests. Predictive values of these tests, odds ratios and their $95 \%$ confidence intervals were used to assess their diagnostic accuracy. The calculations were then repeated for the differences between recalled and objectively measured BMI values. For this purpose, we used $22 \mathrm{~kg} / \mathrm{m}^{2}$ as a second cutoff point for recalled BMI. This point was chosen since (in The Netherlands) the median BMI at age $20-30$ years is $22 \mathrm{~kg} / \mathrm{m}^{2}(25)$. The resulting 'true positive' and 'false positive' rates allowed us to calculate diagnostic DEXA costs per ostoporotic or low BMD patient detected The costs for DEXA measurement in a bone density unit or diagnostic center were 
estimated at about Euro 75 (1 Euro $\simeq 1$ \$) per scan, disregarding related costs such as those for calling up patients, etc. ${ }^{(15,26)}$.

\section{RESULTS}

The characteristics of the 1155 patients are shown in table 1. They are similar to those of the whole population. In table $\mathbb{1}$ the whole population consists of 4203 instead of 4725 patients. The reason is that during the first four weeks of the study period there were practical limitations with respect to the simultaneous measurements of BMD on the one hand and the biometrical measurements and survey on the other. The prevalence of osteoporosis in our study population was $25 \%(285 / 1155)$, while that of low BMD was $65 \%(750 / 1155)$. The median self-reported height exceeded objectively measured height by $3 \mathrm{~cm}$. However, the related effect on BMI was limited. Odds ratios and predictive values for osteoporosis and for low BMD are shown in tables $2^{\mathrm{a}}$ and $2^{\mathrm{b}}$. Only the age-BMI tests 'age $\geq 60, \mathrm{BMI} \leq 27$ showed predictive values for osteoporosis and low BMD higher than the prior probabilities for these conditions. Therefore, calculations of the differences between recalled and objectively measured BMI were only made for women over 60 years of age (tables $3^{\mathrm{a}}$ and $3^{\mathrm{b}}$ ). Since the resulting odds ratios were no longer statistically significant and the predictive values differed only slightly from the objective and recalled BMIs, diagnostic costs per osteoporotic and per low-BMD patient detected were only calculated for the three age-BMI tests 'age $\geq 60, \mathrm{BMI} \leq 27$ (tables $4^{\mathrm{a}}$ and $4^{\mathrm{b}}$. The tables also show the related numbers of undetected patients and the number of scans required to detect one osteoporotic patient or one patient with low BMD.

The objective BMI test detected only $50 \%(143 / 285)$ of the osteoporotic patients in the study population, while the self-reported BMI test and the recalled BMI test showed detection rates of $55 \%(156 / 285)$ and $69 \%(196 / 285)$ respectively. Concomitant costs per osteoporotic patient detected rose by $24 \%$ [(243-185)/243]. Detection of patients with low BMD showed a comparable picture. Detection rates increased from $38 \%$ (285/750) for objective BMI and $42 \%$ $(316 / 750)$ for self-reported BMI to $60 \%$ (452/750) for recalled BMI. Related costs increased by $11 \%$ [(105-93)/105]. If all women over 50 years of age (irrespective of their BMT) were to be referred for BMD measurement, costs per osteoporotic or low-BMD patient detected would be 304 and 116 Euros respectively. Using the latter strategy would of course mean that no patient is missed.

\section{DISCUSSION}

Only in women over $60 \mathrm{did}$ a BMI $\leq 27 \mathrm{~kg} / \mathrm{m}^{2}$ (irrespective of the way in which it is measured) 
provide a more accurate prediction of osteoporosis or low BMD than can be expected solely on the basis of the relevant prevalences in postmenopausal women aged 50 - 80 years. Even in this category of women, however, predicted probabilities are not impressive. Furthermore, if age $(\geq 60)$ and $\mathrm{BMI}(\leq 27)$ were to be used for screening purposes, the relationship between diagnostic costs per patient detected and the numbers of missed patients would be disappointing, again irrespective of the way BMI is measured. In particular if screening were aimed at detecting as many postmenopausal women with low BMD as possible, costs of selecting or not selecting on the basis of age and BMI would differ only slightly: In The Netherlands, measurements of BMD could be implemented in the current screening program for breast cancer. In this screening program, women between 50 and 75 years of age are examined by radiography on a five-yearly basis. DEXA measurements could be performed in the same session. Repeating DEXA measurements every five years would be relevant on the basis of current knowledge about normal bone loss over a five-year period. This conclusion must of course be related to the cost-effectiveness of any intervention strategy, which was not the subject of our study.

On the other hand, if the use of BMI for the detection of osteoporotic or low-BMD patients is considered, there is no real need for an objective measurement of height. Despite people's systematic overestimation of their height, predictive values for osteoporosis and low BMD are only slightly lower for subjectively obtained than for objectively measured height. Hence, measuring weight and just asking for a persons height will do. The overestimation of height by elderly women is probably associated with the physiologic loss of height with age. Most people remember their height as it is stated in their passport and as it was measured at the time. Another component of this overestimation may be that in the past measurements did not take place according to standard procedures, (e.g. with shoes on). Furthermore, many elderly women do not such as to admit to 'getting old'. They dissuch as losing both their youth and their height. In our study, no correction was made for weight by subtracting the approximate weight of one outer and one inner layer of clothes. Since, however, the same weights were used in comparing self-reported and measured data a correction would not have influenced the results.

From a theoretical point of view, it is especially the difference between recalled and actual BMI which would be expected to be a good predictor of osteoporosis or low BMD. However, the relevant odds ratios did not support this view. The explanation could be that weight before menopause does not influence BMD and that gaining weight or becoming overweight after the menopause decreases (or prevents) postmenopausal bone loss. Although the use of recalled weight in anthropometric studies has been disputed ${ }^{(9,10)}$, high correlation levels between measured and recalled weight ${ }^{(10)}$ justify the use of the latter, especially since mistakes in reporting recalled weight are not influenced by present weight, present BMI category, age or 
education in women ${ }^{(2-11)}$. Several studies have used span to estimate height at age 20-30 years. We measured span in a large sample (more than 3000) of the study population. Despite the use of a special wall-mounted diagram with centimeter scale and well-instructed research nurses, it became clear that an accurate measurement was not possible. The physical condition of many elderly women made them unable to straighten their arms fully. Thus we decided not to use this variable.

The relationship between BMI and BMD should preferably be studied in a longitudinal way. By comparing recalled with present BMI, we included a longitudinal aspect in our crosssectional study. However, the absence of significant odds ratios makes it less likely that a strong etiological relationship exists between BMI and BMD. Usually BMD of the hip is slightly higher than BMD of the lumbar spine. Since we measured the spine (instead of hip plus spine), our predictive values might be relatively optimistic. The increase of degenerative conditions of the skeleton with age (especially osteophytosis and osteochondrosis) may reduce the accuracy of lumbar spine measurements in the elderly ${ }^{(27,28,29)}$. However, it was deliberately decided to measure spine instead of hip, since measuring almost 5000 patients within a relatively short period of time, would have resulted in logistical problems. Furthermore, our predictive values were already disappointing with the lumbar spine measurement and comparable to those of a study in France ${ }^{(30)}$. In general we followed the advice of the relevant study group by doing a more precise study on the subject ${ }^{(31)}$.

Although age and BMI are the strongest risk factors for osteoporosis, they are of less significance when used for screening the population for osteoporosis. Furthermore, the ultimate aim of screening should be the prevention of osteoporosic fractures. It is not known to what extent age, BMI and BMD are independent predictors of these fractures. Hence, more research is needed before age and BMI can definitely be included in any screening program. Since osteoporosis and breast cancer are common health problems in post-menopausal women, and since the two conditions are related, as regards practical considerations alone, measurements of BMD could be implemented within in the current screening program for breast cancer ${ }^{(32)}$. 
Table 1. Characteristics of the study population $(\mathrm{N}=1155)$, compared with the whole population $(\mathrm{N}=4203)$

\begin{tabular}{|c|c|c|c|c|}
\hline$\cdots \quad x$ & study popullation & 1155 & whole population & 203 \\
\hline Variable & mean (SD) & median (Q1-Q3) & mean (SD) & median $(Q 1-Q 3)$ \\
\hline $\mathrm{BMD}\left(\mathrm{gr} / \mathrm{cm}^{2}\right)$ & $0.921(0.166)$ & $\begin{array}{l}0.912 \\
(0.802-1.0117)\end{array}$ & $0.925(0.163)$ & $\begin{array}{l}0.913 \\
(0.818-1.038)\end{array}$ \\
\hline age (years) & $63(7)$ & $62(57-68)$ & $63(7)$ & $62(57-68)$ \\
\hline weight (kg) & 71 (13) & $70 \quad(62-78)$ & $71(12)$ & $70 \quad(63-78)$ \\
\hline height $(\mathrm{cm})$ & $162(6)$ & $162(157-165)$ & $161(6)$ & $161(157-165)$ \\
\hline self-reported height $(\mathrm{cm})$ & $164(6)$ & $165(160-168)$ & & \\
\hline recalled weight $(\mathrm{kg})$ & $-60(1.0)$ & $60 \quad(53.65)$ & & \\
\hline objective $\quad$ BMI $\left(\mathrm{kg} / \mathrm{m}^{2}\right)$ & $27(5)$ & $27(24-29)$ & $27 \quad(5)$ & $27(24-30)$ \\
\hline self-reported BMT $\left(\mathrm{kg} / \mathrm{m}^{2}\right)$ & $26(4)$ & $26(23-29)$ & 9 & \\
\hline recalled $\quad$ BMT $\left(\mathrm{kg} / \mathrm{m}^{2}\right)$ & $22(4)$ & $22 \quad(20-24)$ & & \\
\hline
\end{tabular}

Table 2a Diagnostic acauracies of 12 age-BMI tests for osteoponosis, $\mathrm{m}=1155$

\begin{tabular}{|c|c|c|c|c|c|c|c|c|}
\hline \multirow[t]{2}{*}{ BMI test } & \multicolumn{2}{|c|}{ Age $<60, \mathrm{BM}>27$} & \multicolumn{2}{|c|}{ Age $>60, \quad B M I>27$} & \multicolumn{2}{|c|}{ Age $\leq 60$, BMI $\leq 27$} & \multicolumn{2}{|c|}{ Age $>60$, BMI $\leq 27$} \\
\hline & $\begin{array}{l}\text { OR } \\
95 \% \text { cil. }\end{array}$ & $\begin{array}{l}\mathrm{n} \\
\mathrm{PV}+\mathrm{PV}- \\
\mathrm{Se} \\
\mathrm{Sp}\end{array}$ & $\begin{array}{l}\text { OR } \\
95 \% \mathrm{ci}\end{array}$ & $\begin{array}{l}\mathrm{n} \\
\mathrm{PV}+\mathrm{PV}- \\
\mathrm{Se} \\
\mathrm{Sp}\end{array}$ & $\begin{array}{l}\text { OR } \\
95 \% \text { ci }\end{array}$ & $\begin{array}{l}\mathrm{n} \\
\mathrm{PV}+, \mathrm{PV}- \\
\mathrm{Se} \\
\mathrm{Sp}\end{array}$ & $\begin{array}{l}\text { OR } \\
95 \% \text { ci. }\end{array}$ & $\begin{array}{l}\mathrm{D} \\
\mathrm{PV}+\mathrm{PV}- \\
\mathrm{Se} \\
\mathrm{Sp}\end{array}$ \\
\hline $\begin{array}{c}\text { objective } \\
\text { BMR }\end{array}$ & $\begin{array}{l}0.32 \\
0.20-0.52\end{array}$ & $\begin{array}{l}n=182 \\
11,73 \\
S e=7 \\
S p=81\end{array}$ & $\begin{array}{l}0.62 \\
0.21-0.83\end{array}$ & $\begin{array}{l}\mathrm{n}=337 \\
19,73 \\
\mathrm{Se}=22 \\
\mathrm{Sp}=69\end{array}$ & $\begin{array}{l}0.75 \\
0.54-1.04\end{array}$ & $\begin{array}{l}n=284 \\
21,74 \\
S e=21 \\
S p=74\end{array}$ & $\begin{array}{l}3.18 \\
2.41-4.21\end{array}$ & $\begin{array}{l}n=352 \\
41,82 \\
\mathrm{Se}=50 \\
\mathrm{sp}=76\end{array}$ \\
\hline $\begin{array}{l}\text { self- } \\
\text { reported } \\
\text { BMI }\end{array}$ & $\begin{array}{l}0.35 \\
0.21-0.46\end{array}$ & $\begin{array}{l}n=157 \\
12,73 \\
S e=6 \\
S p=84\end{array}$ & $\begin{array}{l}0.60 \\
0.43-0.84\end{array}$ & $\begin{array}{l}n=279 \\
18,73 \\
S e=18 \\
S p=82\end{array}$ & $\begin{array}{l}0.68 \\
0.49-0.94\end{array}$ & $\begin{array}{l}n=309 \\
20,74 \\
S e=21 \\
S p=71\end{array}$ & $\begin{array}{l}2.93 \\
2.22-3.86\end{array}$ & $\begin{array}{l}\mathrm{n}=410 \\
38,83 \\
\mathrm{Se}=55 \\
\mathrm{Sp}=71\end{array}$ \\
\hline $\begin{array}{l}\text { recalled } \\
\text { BMI }\end{array}$ & $\begin{array}{l}0.37 \\
0.14-0.95\end{array}$ & $\begin{array}{l}\mathrm{n}=45 \\
11,75 \\
\mathrm{Se}=2 \\
\mathrm{Sp}=95\end{array}$ & $\begin{array}{l}0.72 \\
0.35-1.45\end{array}$ & $\begin{array}{l}\mathrm{n}=52 \\
19,75 \\
\mathrm{Se}=4 \\
\mathrm{Sp}=95\end{array}$ & $\begin{array}{l}0.54 \\
0.39-0.71\end{array}$ & $\begin{array}{l}n=421 \\
18,71 \\
S e=26 \\
S p=60\end{array}$ & $\begin{array}{l}2.14 \\
1.61-2.84\end{array}$ & $\begin{array}{l}n=637 \\
31,83 \\
S e=69 \\
S p=49\end{array}$ \\
\hline
\end{tabular}

$\mathrm{OR}=$ odds ratio, $95 \% \mathrm{c} \mathrm{i}=95 \%$ confidence interval, $\mathrm{PV}+=$ positive predictive value $(\%), \mathrm{PV}$ - =negative predictive value $(\%)$, Se=sensitivity $(\%), \mathrm{Sp}=$ specificity $(\%)$.

ORs were calculated for the relationstip between the prevalence of osteoporosis in the relevant BMI-stibgroup and the prevalence of osteoporosis in the remaining subgroups. 
Table $2 \mathrm{~b}$ Dingnostic accuracies of 12 , age-BMI tests for low $\mathrm{BMD}, \mathrm{n}=1155$

\begin{tabular}{|c|c|c|c|c|c|c|c|c|}
\hline \multirow[t]{2}{*}{ BMI test } & \multicolumn{2}{|c|}{$A g<60, B M D>27$} & \multicolumn{2}{|c|}{$A g e \geq 60, B M I>27$} & \multicolumn{2}{|c|}{ Age $<60$, BMI $\leq 27$} & \multicolumn{2}{|c|}{ Age $\geq 60$, BMI $\leq 27$} \\
\hline & $\begin{array}{l}\text { OR } \\
95 \% c 1\end{array}$ & $\begin{array}{l}n \\
\mathrm{pV}+\mathrm{pV} \text {. } \\
\mathrm{se} \\
\mathrm{Sp}\end{array}$ & $\begin{array}{l}\text { OR } \\
95 \% \text { c.1. }\end{array}$ & $\begin{array}{l}\text { in: } \\
\mathrm{PV}+\mathrm{PV} \text {. } \\
\mathrm{Se} \\
\mathrm{Sp}\end{array}$ & $\begin{array}{l}\text { OR } \\
95 \% \mathrm{ci}\end{array}$ & $\begin{array}{l}\text { n } \\
\mathrm{PV}_{+}, \mathrm{PV}- \\
\mathrm{Se} \\
\mathrm{Sp}\end{array}$ & $\begin{array}{l}\text { OR } \\
95 \% \mathrm{ci} .\end{array}$ & $\begin{array}{l}n \\
\mathrm{PV}+\mathrm{PV}- \\
\mathrm{Se} \\
\mathrm{Sp}\end{array}$ \\
\hline $\begin{array}{l}\text { objective } \\
\text { BMI }\end{array}$ & $\begin{array}{l}0.49 \\
0.360 .68\end{array}$ & $\begin{array}{l}\mathrm{n}=182 \\
51,32 \\
\mathrm{Se}=12 \\
\mathrm{Sp}=78\end{array}$ & $\begin{array}{l}0.66 \\
0.51-0.87\end{array}$ & $\begin{array}{l}n=337 \\
58,32 \\
S e=35 \\
S p=65\end{array}$ & $\begin{array}{l}0.86 \\
0.65-1.14\end{array}$ & $\begin{array}{l}n=284 \\
62,34 \\
S e=24 \\
s p=74\end{array}$ & $\begin{array}{l}3.04 \\
2.25-4.10\end{array}$ & $\begin{array}{l}n=352 \\
81,42 \\
S e=38 \\
S p=83\end{array}$ \\
\hline $\begin{array}{l}\text { selfo } \\
\text { reported } \\
\text { BMI }\end{array}$ & $\begin{array}{l}0.48 \\
0.34-0.68\end{array}$ & $\begin{array}{l}\mathrm{n}=157 \\
50,33 \\
\mathrm{Se}=10 \\
\mathrm{Sp}=81\end{array}$ & $\begin{array}{l}0.72 \\
0.54-0.94\end{array}$ & $\begin{array}{l}n=279 \\
59,33 \\
S e=22 \\
S p=72\end{array}$ & $\begin{array}{l}0.84 \\
0.64-1.09\end{array}$ & $\begin{array}{l}n=309 \\
62,34 \\
S e=26 \\
S p=71\end{array}$ & $\begin{array}{l}2.42 \\
1.84-3.18\end{array}$ & $\begin{array}{l}n=410 \\
77,42 \\
S e-42 \\
S p=77\end{array}$ \\
\hline $\begin{array}{l}\text { recalled } \\
\text { BMII }\end{array}$ & $\begin{array}{l}0.31 \\
0.17-0.58\end{array}$ & $\begin{array}{l}n=45 \\
37,34 \\
S e=2 \\
S p=93\end{array}$ & $\begin{array}{l}0.53 \\
0.30-0.92\end{array}$ & $\begin{array}{l}\mathrm{n}=52 \\
50,35 \\
\mathrm{Se}=3 \\
\mathrm{Sp}=93\end{array}$ & $\begin{array}{l}0.71 \\
0.55-0.91\end{array}$ & $\begin{array}{l}n=421 \\
60,32 \\
s e=34 \\
s p=58\end{array}$ & $\begin{array}{l}1.87 \\
1.47-2.93\end{array}$ & $\begin{array}{l}\mathrm{n}=637 \\
71,43 \\
\mathrm{Se}=61 \\
\mathrm{Sp}=55\end{array}$ \\
\hline
\end{tabular}

$\mathrm{OR}=$ odds ratio, $95 \% \mathrm{c} \mathrm{i}-95 \%$ confidence interval, $\mathrm{PV}-\mathrm{t}$ positive predictive value $(\%), \mathrm{PV}$ - negative predictive value $(\%)$ Se sensitivity $(\%)$, Sp specificity $(\%)$

ORs were calculated for the relationship between the prevalence of osteoporosis in the relevant BMI-subgroup and the prevalence of osteoporosis in the remaining subgroups.

Table 3a. Relationship between recalled and objectively metasured BMI in women over 60 years of age (n 690 ).

\begin{tabular}{|c|c|c|c|c|}
\hline & & \multicolumn{2}{|c|}{ Objectively measured BMI } & \\
\hline & & $\leq 27$ & $>27$ & \\
\hline $\begin{array}{c}\text { recalled } \\
\text { BMI }\end{array}$ & $\leq 27$ & $\begin{array}{l}n=340 \\
p v t \text { for ostcoporosis }=41 \% \\
(n=139) \\
p v+\text { for low BMD }=81 \% \\
(n=277)\end{array}$ & $\begin{array}{l}n=297 \\
\text { pvt for osteoporosis }=19 \% \\
(n=57) \\
p w+\text { for low BMD }=60 \% \\
(n=177)\end{array}$ & $n=637$ \\
\hline & $>27$ & $\begin{array}{l}n=12 \\
\text { pwt for osteoporosis }=33 \%(n=4) \\
\text { pwt for low BMD }=58 \% \\
(n=7)\end{array}$ & $\begin{array}{l}n=41 \\
p v+\text { for osteoporosis }=15 \%(n-6) \\
p N+\text { for low BMD }=46 \% \\
(n=19)\end{array}$ & $n=53$ \\
\hline & & $n=352$ & $\mathrm{n}=3338$ & $n=690$ \\
\hline & & $\begin{array}{l}\text { OR for osteoporosis } \\
\qquad \begin{array}{l}1.4(\text { ci. } 0.4-4.6) \\
\text { OR for low BMD } \\
\quad 3.1(\text { ci. } 1.0-10.2)\end{array}\end{array}$ & $\begin{array}{l}\text { OR for osteoporosis } \\
\qquad 1.4(\mathrm{c} .10 .6-3.5) \\
\text { OR for low BMD } \\
1.7(\text { c.i. } 0.9-3.3)\end{array}$ & \\
\hline
\end{tabular}

pw $=$ positive predictive value, $\mathrm{OR}=$ odds ratio $(\mathrm{c} . \mathrm{i}=95 \%$ confidence interval)All percentages have been rounded off 
Table 3b. Relationship between recalled and objectively measured BMI in women over 60 years of age ( $\mathrm{n}=690$ )

\begin{tabular}{|c|c|c|c|c|}
\hline & & \multicolumn{2}{|l|}{ Objectively measuned BMI } & \\
\hline & & $\leq 27$ & $>27$ & \\
\hline $\begin{array}{c}\text { recalled } \\
\text { BMII }\end{array}$ & $\leq 22$ & $\begin{array}{l}n=210 \\
\text { pwt for osteoporosis }=44 \%(n=92) \\
p w+\text { for low BND } \quad=83 \%(n=175)\end{array}$ & $\begin{array}{l}\text { n } 129 \\
\text { pvt for osteoporosis }=17 \%(\mathrm{n}=22) \\
\text { pNt for low BMD }=53 \%(\mathrm{n}=68)\end{array}$ & $n=339$ \\
\hline & $>22$ & $\begin{array}{l}n=142 \\
p v+\text { for osteoporosis }=36 \%(n=51) \\
p v+\text { for low BMD }=77 \%(n=109)\end{array}$ & $\begin{array}{l}n=209 \\
p v+\text { for osteoponasis }=20 \%(n=41) \\
p v+\text { for low BMD } \quad=61 \%(n-128)\end{array}$ & $\mathrm{n}=351$ \\
\hline & & $\mathrm{n}=352$ & $\mathrm{n}=33 \mathrm{~s}$ & $n=690$ \\
\hline & & $\begin{array}{l}\text { OR for asteoporosis } \\
1.4(\text { c.i. } 0.9-2.2) \\
\text { OR for low BMD } \\
\quad 3.1 \text { (c.i. } 0.8-2.4)\end{array}$ & $\begin{array}{l}\text { OR for osteoporosis } \\
0.8(c, 0.5-1.4) \\
\text { OR for low BMD } \\
0.7(c .1: 0.5-1.1)\end{array}$ & \\
\hline
\end{tabular}

pvt =positive predictive value, $O R=$ odds ratio ( $c . i=95 \%$ confidence interval) All percentages have been rounded of:

Table 4a. Costs per osteoporotic patient detected using three different BMI tests.

\begin{tabular}{|c|c|c|c|c|c|c|}
\hline \multicolumn{7}{|c|}{ Study population $n=1155,1$ scan $=$ Euro 75} \\
\hline \multirow[t]{2}{*}{ BMI test } & \multicolumn{6}{|c|}{ Age $\geq 60$ and $B M L \leq 7$} \\
\hline & $\mathrm{PV}+(\%)$ & $\begin{array}{l}\text { number } \\
\text { of } \\
\text { scans }\end{array}$ & $\begin{array}{l}\text { OP } \\
* \\
n\end{array}$ & $\begin{array}{l}\text { costs per } \\
\text { osteoporotic patient } \\
\text { detected (Euro) }\end{array}$ & $\begin{array}{l}\text { number of scans } \\
\text { required to detect one } \\
\text { osteoporotic patient }\end{array}$ & $\begin{array}{l}\text { number of missed } \\
\text { osteoporotic } \\
\text { patients }\end{array}$ \\
\hline $\begin{array}{l}\text { objective } \\
\text { BMII }\end{array}$ & $41 \%$ & 352 & 143 & $26400 / 143=185$ & $352 / 143=2.46$ & 142 \\
\hline $\begin{array}{l}\text { self-reported } \\
\text { BMI }\end{array}$ & $38 \%$ & 410 & 156 & $30700 / 156=197$ & $410 / 156=2.62$ & 129 \\
\hline $\begin{array}{l}\text { recalled } \\
\text { BMI }\end{array}$ & $31 \%$ & 637 & 196 & $47775 / 196=243$ & $637 / 196-3.25$ & 89 \\
\hline
\end{tabular}

Total study population scanned (n= 1155 , prevalence of osteoporosis $-25 \%$ )

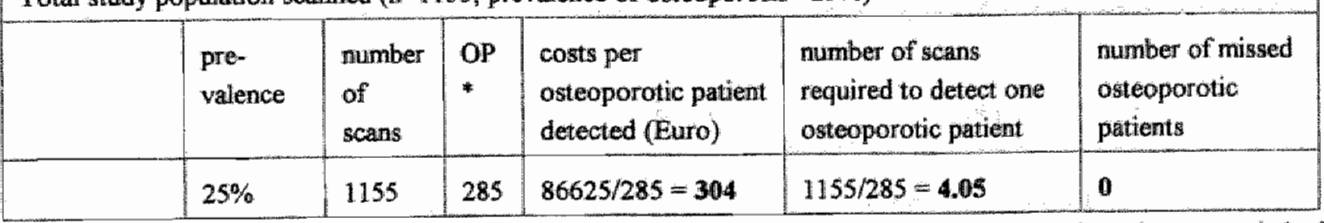

* OP=number of paticnts with osteoporosis, $\mathrm{PV}+=$ positive predictive value. All percentagesi have been rounded off. 
Table $4 \mathrm{~b}$. Costs per patient with low BMD detected using three different BMI tests.

\begin{tabular}{|c|c|c|c|c|c|c|}
\hline \multicolumn{7}{|c|}{ Study population $n=1155,1$ scan $=$ Euro 75} \\
\hline \multirow{2}{*}{ BMU test } & \multicolumn{6}{|c|}{ Age $>60$ and $B M I \leq 27$} \\
\hline & $P W+(\%)$ & $\begin{array}{l}\text { number } \\
\text { of } \\
\text { scans }\end{array}$ & $\begin{array}{l}\text { LB } \\
(n)\end{array}$ & $\begin{array}{l}\text { costis per pattient } \\
\text { with low BND } \\
\text { detected (Euro) }\end{array}$ & $\begin{array}{l}\text { number of scans } \\
\text { requiried to detect one } \\
\text { patient with low BMD }\end{array}$ & $\begin{array}{l}\text { number of missed } \\
\text { patients with low } \\
\text { BMD }\end{array}$ \\
\hline $\begin{array}{l}\text { objective } \\
\text { BMI }\end{array}$ & $81 \%$ & 352 & 285 & $26400 / 285=93$ & $352 / 285=1.24$ & 466 \\
\hline $\begin{array}{l}\text { self-weported } \\
\text { BMII }\end{array}$ & $77 \%$ & 410 & 316 & $41000 / 316=97$ & $4110 / 316=1.30$ & 434 \\
\hline $\begin{array}{c}\text { recalled } \\
\text { BMI }\end{array}$ & $71 \%$ & 637 & 452 & $63700 / 452=105$ & $637 / 452=11.41$ & 296 \\
\hline \multicolumn{7}{|c|}{-100} \\
\hline \multicolumn{7}{|c|}{ Total study population scamined $(n=1155$, prevalence of low $B M D=65 \%)$} \\
\hline & $\begin{array}{l}\text { pre- } \\
\text { valence }\end{array}$ & $\begin{array}{l}\text { number } \\
\text { of } \\
\text { scans }\end{array}$ & LB & $\begin{array}{l}\text { Costs per patient } \\
\text { with low BMD } \\
\text { detected (EURO) }\end{array}$ & $\begin{array}{l}\text { number of scans } \\
\text { required to detect one } \\
\text { patient with low BMD }\end{array}$ & $\begin{array}{l}\text { number of missed } \\
\text { patients with low } \\
\text { BMD }\end{array}$ \\
\hline & $65 \%$ & 1155 & 750 & $86625 / 750=116$ & $1155 / 750=1.54$ & 0 \\
\hline
\end{tabular}

* $\mathrm{LB}=$ number of patients with low BMD, PV+ = positive predictive value. All percentages have been rounded off. 


\section{REFERENCES}

1 Roberts RJ. Can self-reported data accurately describe the prevalenoe of overweight? Public Health $1995 ; 109(4): 275-84$

2 Schmidt MI, Duncan BB, Tavares M, Polanczyk CA, Pellanda L, Zimmer PM. Validity of self-reported weight. A study of urban Brazilian adults. Revista de Saude Publica 1993;27(4):271-76

3 Alvarez-Torices JC, Franch-Nadal. J, Alvarez-Guisasola F, Hernandez-Mejiz R, Cueto-Espinar A Selfreported height and weight and prevalence of obesity. Study in a Spanish population Int J Obes Relat Metab Disord 1993;17(11):663-67

4 Kuskowska-Wolk A, Bergstrom R, Bostrom G. Relationship between questionnaine data and medical records of height, weight and body mass index. Int J Obes Relat Metab Disord 1992;16(2):1-9

Kuskowska-Wolk A, Karlsson P, Stolt M, Rössner S. The predictive validity of body mass index based on self-reported weight and height. Int J Obes 1989;13:441-53

6 Stewart AW, Jackson RT, Ford MA, Beaglehole R Underestimation of relative weight by use of selfreported height and weight. Am J Epidemiol 1987;125(1):122-26

7. Jalkanen L, Tuomilehto $J$, Tanskanen A, Puska P. Accuracy of self-reported body weight compared to measured body weight. Scand J Soc Med 1987,15:191-98

8 Nieto-Garcia FJ, Bush TL, Penelope MK. Body mass definitions of obesity. sensitivity and specificity using self-reported weight and height. Epidemiology 1990;1:146-52

9 Troy $\mathrm{LM}$, Hunter $\mathrm{DJ}$, Manson JE, et al. The validity of recalled weight among younger women. Int $\mathrm{J}$ Obes 1995;19:570-72

10. Must A, Willett WC, Dietz WH. Remote recall of childhood height; weight and body build by elderly subjects. Am J Epidemiol 1993;138(1):56-64

11. Casey VA, Dwyer JT, Berkey CS, Coleman KA, Gardner J; Valadian L. Long-term memory of body weight and past weight satisfactiom: a longitudinal follow-up study. Am J Clin Nutr 1991;53:1493-98 Stevens J, Keil JE, Waid LR, Gazes PC. Accuracy of current, 4-year, and 28-year self-reported body weight in an elderly population. Am J Epidemiol 1990;132(6):1156-63

Law MR, Wald NJ, Meade TW. Strategies for prevention of osteoporosis and hip fractures. Br Med J $1991 ; 303: 453-59$

Osteoporosis: a decision-making document for diagnosis and prevention. National osteoporosis society, 1994

Wilson JMG, Jungner G. Principles and practice of screening for disease. Geneva: WHO, 1986 Diagnostic accuracy of an algorythm for quick detection of patients with low bone mineral density in daily general practice. Accepted for Journal of Clinical epidemiology.

Compston JE, Cooper C, Kanis JA. Bone densitometry in clinical practice. Br Med J 1995;310:1507-10 Miller PD, Bonnick SL, Rosen CJ. Consensus of an international panel on the clinical utility of bone mass measurements in the detection of low bone mass in the adult population. Calcif Tissue Int $1996,58: 207-14$

19 Wahner HW, Fogelman I. The evaluation of osteoporosis: Dual energy X-ray absorptiometry in elimical practice. Cambrìdge: University Press, 1994 
Hailey D NAHT project on bone density meastrements and treatments for osteoporosis. Background paper 1. Methodls used in the measurement of bone density. Edmenton: Alberta Heritage Foundation for Medical Research, 1996

21. Dixon WJ, Brown MB, Engelman L, Holl MA, Jenrich RI. BMDP statistical software mamual. Berkeley. University of Califomia Press, 1990

22 Assessment of fracture risk and its application to screening for postmenopausal osteoporosis. Geneva: WHO Technical report series 843,1994

23 Bone Density Reference Data Bruxelles: S.A. Hologic Europe.

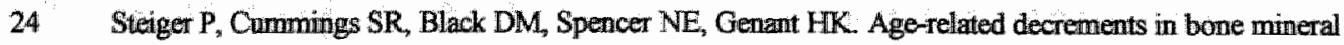
density in women over 65. J Bone Miner Res 1992;7.625-32

25 Statistisch Jaanboek 1995. s'Gravenhage: Centraal Bureau woor de Statistiek, 1995

26. Office of technology assessment. Effectiveness and casts of osteoporosis screening and hormone replacement therapy. Washington: Office of technology assessment, 1995

27 Von der Recke P, Hamsen MA, Overgaard K, Christiansen C. The impact of degenerative conditions in the spine on bone mineral density and fracture risk prediction. Osteoporosis Int 1996;6:43-49

28 Rand Th, Seidl G, Kainberger F, Resch A, Hitmair K, Schneider B et al Impact of spinal degenerative changes on the evaluation of bone mineral density with dual energy $x$-ray absorptiometry (DXA). Calcif Tissue lnt 1997;60:430:33

29 Rand Th, Schneider $B$, Grampp S, Wunderbaldinger P, Migsits H, Imhof H. Influence of osteophytic size on bone mineral density measured by dual x-ray absorptiometry. Acta Radiologica 1997;38:210-13

30 Tremollieres FA, Pouilles JM, Ribot C. Vertebral postmenopausal bone loss is reduced in overweight women: a longitudinal study in 155 early postmenopausal womem. J Clin Endocrinol Metab $1993 ; 77: 683-86$

31. Ribot C, Tremollieres FA, Pouilles JM. Can we detect women with low bone mass using clinical risk factors: Am J Med 1995;98:suppl 2A,52S-55S

32 Zhang $\mathbf{Y}$, Kiel DP, Kreger BE, Cupples LA, Curtis-Ellisom $R$, Dorgan J, et al. Bone mass and the risk of breast cancer among postmenopausal women. N Engl J Med 1997;336(9):611-19

\subsection{Samenvatting}

Doel van de studie. Bepalen wat de diagnostische waarde is van de objectief gemeten bady mass index (BMI); de door de patiěnt vermelde huidige (-subjectieve) BMI en de BMI berekend op basis van het herinnerde gewicht en de opgegeven lengte op 25-30 jarige leeftijd, ter vaststelling van osteoporose en osteopenie. Tevens wilden we bepalen hoeveel BMD metingen er met de drie verschillend bepaalde BMr's (de BMI-testen) nodig zijn om een osteoporotische patient of patiente met osteopenie te ontdekken. Het derde doel was om te bekijken in welke mate de resultaten kunnen worden gebruikt binnen het bestaande screeningsprogramma voor borstkanker.

Patiënten en methoden. In onze crosssectionele studie naar het voorkomen van osteoporose vroegen wij aan 1155 vrouwen in de leeftijd van 50-80 jaar naar hun lengte en naar hun ge- 
wicht op 25-30 jarige leeftijd. Vervolgens werden hun gewicht en lengte gemeten en werd de BMD bepaald van de lumbale wervelkolom. Het afkappunt voor osteoporose was een BMD van $0,800 \mathrm{gr} / \mathrm{cm}^{2}$, voor een 'lage BMD' (osteoporose + osteopenie) gold een afkappunt van $0,970 \mathrm{gr} / \mathrm{cm}^{2}$. De met behulp van ROC analyse voor de leeftijd en voor de BMI bepaalde afkappunten waren respectievelijk $60 \mathrm{jaar}, 27 \mathrm{~kg} / \mathrm{m}^{2}$. De diagnostische waarde van de objectief gemeten BMI de subjectieve BMI en de BMI op 25-30 jarige leeftijd werd bepaald aan de hand van voorspellende waarden (PVs) en odds ratios. De 'werkelijk positieve' en 'werke-lijk negatieve' scores werden gebruikt on te berekenen hoeveel BMD-bepalingen er verricht moeten worden om een osteoporotische patiente of een patiente met osteopenie te vinden.

Resultaten: De prevalentie van osteoporose in de studiepopulatie was $25 \%$, die van een te la-ge BMD was $65 \%$. Slechts de testen met de combinatie leeftijd $\geq 60$ en $\mathrm{BMI} \leq 27$ leverde PVs op voor osteoporose $(31 \%-41 \%)$ en voor een lage BMD $(71 \%-81 \%)$ die hoger waren dan de vooraf kans voor deze condities. De betreffende odds ratios waren 2,14-3,18 (voor osteoporose) en 1,87-3,04 (voor een lage BMD). De objective BMI-test detecteerde 50\% van de osteoporotische patiënten. Gebruikmakend van de subjectieve BMI-test en de vroegere BMI-test liep het percentage gedetecteerden op van $55 \%$ tot $69 \%$. De daarmee samenhangende kosten stegen per gevonden patiënt met $24 \%$. De detectie van patiënten met een lage BMD nam toe van $38 \%$ voor de objectieve BMI en $42 \%$ voor de subjectieve BMI tot $60 \%$ voor de vroegere $\mathrm{BMI}$. De daarmee samenhangende kosten stegen met $11 \%$. Indien alle vrouwen boven de 50 jaar zouden worden verwezen voor een BMD-bepaling zou het vinden van een osteoporotische patiënte circa 304 Euro kosten. Het vinden van een patiënte met osteopenie zou dan circa 116 Euro kosten.

Conclusies. Alleen voor vrouwen boven de 60 jaar levert een BMI lager dan $27 \mathrm{~kg} / \mathrm{m}^{2}$ een betere voorspelling op van osteoporose of een lage BMD dan kan worden verwacht op grond van de vooraf kans voor osteoporose in de categorie postmenopauzale vrouwen van 50 tot 80 jaar. Indien echter voor de detectie van osteoporose of een lage BMD gebruik gemaakt wordt van de BMI volstaat het meten van het gewicht en het vragen naar de lengte. Ook al zijn leeftijd en BMI de sterkste risicofactoren voor osteoporose, om ze te gebruiken in screeningsprogramma's voor osteoporose zijn ze van te weinig waarde.

$\mathrm{Er}$ is meer onderzoek nodig alvorens de leeftijd en de BMI kunnen worden gebruikt in screeningsprogramma's voor osteoporose. Het meten van de BMD zou, voor zover het de praktische kant betreft, kunnen worden ingevoegd in het screeningsprogramma voor borstkanker. 
Hoofdstuk 5 


\section{Hoofdstuk 5}

How to use co-morbidity for detecting osteoporosis in daily general practice

1. D.J.M. van der Voort, MD, general practitioner (1)

2. P.P. Geusens, $\mathrm{MD}, \mathrm{PhD}$, professor of Rheumatology (2)

3. G.J. Dinant, $\mathrm{MD}, \mathrm{PhD}$, professor of Clinical Research in General Practice (1)

(1): University of Maastricht, Department of General Practice and Research Institute for Extramural and Transmural Health Care, Maastricht, The Netherlands

(2): Department of Internal Medicine, University Hospital, Maastricht, The Netherlands

Submitted 


\section{ABSTRACT}

Objective: To determine the relationship between the presence of osteoporosis and the presence of osteoporosis-related risk factors, as well as diseases, disease-related complaints and pharmacological treatments ('co-morbidity') in postmenopausal women. To determine to what extent this relationship is useful in detecting osteoporosis in daily general practice.

Design: Cross-sectional study.

Subjects and measurements: A random sample of 1684 postmenopausal women was drawn from all 9107 women aged $50-80$ years registered with 23 general practitioners (GP). The women were examined (weight, height, body mass index and bone mineral density (BMD) of the lumbar spine) and questioned on variables possibly related to osteoporosis (e.g. biometrical and life style data). In addition, all patients were questioned in detail on their medical history and the presence of any disease or health complaint and related pharmacological treatments.

Statistics: Osteoporosis was defined as a value for BMD of the lumbar spine (L2-4) more than $2.5 \mathrm{SD}$ below the young adult mean. Low BMD was defined as a value for BMD of the lumbar spine (L2-4) more than $1 \mathrm{SD}$ below the young adult mean (cutoff points $0.80 \mathrm{~g} / \mathrm{cm}^{2}$ for osteoporosis and $0.97 \mathrm{~g} / \mathrm{cm}^{2}$ for low BMD). All analyses were performed for the total study population and for the subgroups 'Non-consulting', 'GPconsulting' and 'Specialist-consulting' patients. Cross table analyses were done to describe the relationship between the presence of one or more diseases and the presence of osteoporosis or low BMD. Multivariate stepwise backward and forward logistic regression analysis was done with 48 co-morbidity variables and 24 biometrical and lifestyle variables (complete model), using BMD as the dependent variable. After checkup for masking, analyses were repeated with all statistically significant independent variables found in the complete model (final model). Finally, we estimated the clinical significance of the results by calculating the number of osteoporotic patients that could be detected using the results of the final model.

Results. The differences in the prevalences of osteoporosis and low BMD between the subgroups with and without any disease were not statistically significant $(O R=1.13$; $\mathrm{Cl}=0.9-1.42$ for osteoporosis; $\mathrm{OR}=1.19 ; \mathrm{Cl}=0.97-1.44$ for low BMD). Neither were the differences in the prevalences of osteoporosis and low BMD between the GP-consulting and Specialist-consulting categories $(\mathrm{OR}=0.84, \mathrm{Cl}=0.62-1.14$ for osteoporosis; $\mathrm{OR}=0.92, \mathrm{Cl}=0.71-1.18$ for low $\mathrm{BMD}$ ). Having more than one disease seemed to be associated with a lower prevalence of osteoporosis than having none or just one disease, though the difference was not statistically significant $(\mathrm{OR}=0.81, \mathrm{CI}=0.60-1.09$ for osteoporosis; $\mathrm{OR}=0.85 ; \mathrm{CI}=0.66-1.08$ for low $\mathrm{BMD}$ ). In all categories (Non-consulting, GP-consulting and Specialist-consulting) the subgroups with the highest numbers of 
diseases were found to include the lowest percentages of women with osteoporosis and low BMD. This trend was consistent but not statistically significant. Within the subgroups of women with more than one disease with a prevalence over $1 \%$ in an average general practice, the prevalences of osteoporosis were significantly lower than the overall prevalence for all women $(\mathrm{OR}=0.68 ; \mathrm{Cl}=0.47-0.99)$. The prevalence of osteoporosis in women with one disease with a prevalence below $1 \%$ was slightly higher than the overall prevalence for all diseased women ( $O R=1.41 ; \mathrm{Cl}=0.98-2.02$ ). Only six co-morbidity variables showed a statistically significant correlation with the presence of osteoporosis or low BMD. A positive correlation was found for the systemic use of corticosteroids (CS) ( $O R=4.2 ; C l=1.4-12.9$ for osteoporosis in all patients), gastric surgery ( $\mathrm{OR}=10.5 ; \mathrm{Cl}=1.7-67.0$ for osteoporosis in GP-consulting patients) and cervical complaints ( $\mathrm{OR}=3.4 ; \mathrm{Cl}=1.2-9.9$ for osteoporosis in Non-consulting patients). A negative correlation was found for nervousness $(\mathrm{OR}=0.3 ; \mathrm{Cl}=0.1-0.8$ for low $\mathrm{BMD}$ in Non-consulting patients), hypertension ( $\mathrm{OR}=0.5 ; \mathrm{Cl}=0.4-0.8$ for osteoporosis in all patients) and angina pectoris ( $\mathrm{OR}=0.5 ; \mathrm{CI}=0.3-0.9$ for osteoporosis in all patients). The use of thiazide diuretics by patients with hypertension or angina pectoris had no significant influence on BMD. The average general practice ineludes 88 osteoporotic postmenopausal women aged $50-80$ years; 44 in the subgroup with one or more diseases and also 44 in the subgroup without any disease. GPs will be familiar with the medical history of about 228 consulting patients. Of those patients 51 are osteoporotic; 26 in the subgroup GP-consulting, 25 in the subgroup Specialist-consulting. In the non-consulting subgroup $(n=166) 36$ osteoporotic patients are 'hidden'. Hence, in an average general practice, most osteoporotic patients are unknown as such by the GP.

Conclusion. The clinical relevance of co-morbidity for detecting osteoporosis or low BMD in daily general practice is limited. Co-morbidity is important with respect to patient care but useless in screening elderly female populations for the presence of osteoporosis. Either the incidence of relevant complaints, diseases and use of drugs or the percentages of osteoporotic patients are too low. However, all people using CS and all patients with a history of gastric surgery should be checked for the presence of low BMD. Case-finding might be helped by asking consulting patients for the presence of cervical complaints. Cardiovascular disorders are often related to relatively high BMD. Therefore, searching for osteoporosis in this category is less useful. 


\section{INTRODUCTION}

With a prevalence of $25-30 \%$ osteoporosis is a common condition in postmenopausal Caucasian women ${ }^{(1,2)}$. The pathogenetic mechanisms leading to osteoporosis have not yet been fully clarified. The main question is whether osteoporosis is an idiopathic (primary) illness, a secondary process, or the result of multi-factorial causality. Multifactorial not only includes known risk factors (such as age and weight), but also diseases, disease-related complaints and pharmacological treatments (hereafter indicated as co-morbidity). The clinical relevance of co-morbidity for daily general practice regarding osteoporosis is as yet unknown, partly because a considerable number of diseases probably related to osteoporosis are rare or even extremely rare in a general practice setting ${ }^{(3-7)}$. For instance, the incidence of primary hyperparathyroidism, one of the major causes of secondary osteoporosis, is less than 1 per 1000 women per 2-3 years ${ }^{(8)}$. However, because a great variety of diseases are encountered daily in general practice, it could be of help to know those that have a relevant relationship with osteoporosis. The present study concentrated on this question and tried to calculate the numbers of osteoporotic patients that could be detected in an average general practice by using co-morbidity as a screening or case-finding instrument.

\section{METHODS}

\section{Design}

Within the framework of a cross-sectional study on the prevalence of osteoporosis, we asked all patients included in the study for their medical history in relation to comorbidity, including drug treatment, and whether or not they were currently consulting their general practitioner (GP) or a specialist. The latter aspect was included since suffering from a disease does not automatically mean that the patient is consulting his doctor, while, on the other hand, not all consulting patients are suffering from a disease.

\section{Population}

As has been described previously, we performed a cross-sectional study on the prevalence of osteoporosis in daily general practice between October 1992 and March $1994^{(9)} .23$ GPs in 12 general practice centres, all located in the south-east of The Netherlands, provided a list of all 9107 women aged $50-80$ on their register. For the purpose of the present study we analysed a random sample of 1684 postmenopausal women. 


\section{Measurements}

Each visit started with measurements of weight height and bone mineral density (BMD), using a computer guided DEXA instrument (Hologic QDR-1000, Hologic Europe, Brussels, Belgium). With the help of the research nurse, patients then completed a questionnaire on variables possibly related to osteoporosis (e.g. biometrical and life style data). In addition, all patients were questioned in detail on their medical history and the presence of any disease or health complaints and related drug or other treatments. Since low back pain is a very common complaint in dailly general practice and is anatomically related to decreased BMD of the lumbar spine, we specifically asked all patients about this complaint.

\section{Statistics}

Statistical analysis was carried out by means of the BMDP program ${ }^{(10)}$ BMD values were dichotomized at $0.80 \mathrm{~g} / \mathrm{cm}^{2}$ (for osteoporosis) and $0.97 \mathrm{~g} / \mathrm{cm}^{2}$ (for osteopeniatosteoporosis = low BMD $)^{(11)}$. The cutoff points corresponded to 2.5 and 1 standard deviations below the mean BMD of L2-L4, measured in a healthy adult female population aged 30 , using the Hologic QDR-1000 ${ }^{(12,13)}$

The statistical analyses were performed for the total study population $(\mathrm{n}=1684)$ and for the subgroups of patients consulting their GP or a specialist. As a first step, the relationship between the presence of a disease and osteoporosis or low BMD was described. The mean prevalences (per GP) of co-morbidity (147 different diseases; 183 different complaints; 241 different drug treatments) were calculated, using the mean number of listed patients per participating GP as the denominator. Only those comorbidity variables (48) showing a prevalence over $1 \%$ entered the next step. A prevalence of $1 \%$ was chosen since this figure implies that the average GP has at least one such patient in his practice. All 48 remaining co-morbidity variables, as well as the 24 variables from our previous study which were not related to co-morbidity were entered into a logistic regression analysis ('complete model'), using BMD as the dependent variable.

Since the effect of one co-morbidity variable can be masked by the effect of other closely related factors, we indicated those co-morbidity variables that came out as statistically insignificant and then grouped those that were clinically interrelated. One by one these clusters were taken off the regression model ('reduced models'), thereby resulting in a different goodness-of-fit. The differences between the goodness-of-fit of the complete and reduced models were tested using Chi-square If a statistically significant decrease in the goodness-of-fit was found, the variables concerned reentered the regression model: After studying all clusters in this way, final stepwise forward and 
backward logistic regression analyses were done using all remaining statistically significant independent variables. In the final model we added 'history of gastric surgery" because of its explicit relationship with osteoporosis. Finally, we estimated the clinical significance of the results by calculating the number of osteoporotic patients that could be detected by using the results of the final models.

\section{RESULTS}

Table la shows the relationship between the presence of any disease and osteoporosis or low BMD in all patients, as well as in the categories Non-consulting, GP-consulting or Specialist-consulting patients. Women in the subgroup without any disease were younger and had a lower body weight (mean age 60 , mean weight $70 \mathrm{~kg}$ ) than those in the subgroup with some disease (mean age 64 years, mean weight $73 \mathrm{~kg}$ ). However, the differences in the prevalences of osteoporosis and low BMD between these subgroups were not statistically significant $(O R=1.13$, confidence interval $(C I)=0.90-1.42$ for osteoporosis; $O R=1.19, \mathrm{Cl}=0.97-1.44$ for low $\mathrm{BMD}$ ). Neither were the differences in the prevalences of osteoporosis and low BMD between the categories GP-consulting and Specialist-consulting $(\mathrm{OR}=0.84, \mathrm{CI}=0.62-1.14$ for osteoporosis; $\mathrm{OR}=0.92, \mathrm{CI}=0.71$ 1.18 for low BMD). Table la also shows the relationship between the number of diseases and the presence of osteoporosis or low BMD. Having more than one disease seemed to be associated with a lower prevalence of osteoporosis, though the correlation was not statistically significant, compared with having none or only one disease ( $\mathrm{OR}=0.81, \mathrm{Cl}=0.60-1.09$ for osteoporosis; $\mathrm{OR}=0.85 ; \mathrm{Cl}=0.66-1.08$ for low $\mathrm{BMD}$ ). In all categories (Non-consulting, GP-consulting and Specialist-consulting) the subgroups with highest numbers of diseases were found to include the lowest percentages of women with osteoporosis and low BMD. This trend was consistent but not statistically significant. We did not study the subgroup of patients consulting a GP as well as a specialist, because no more than $16 \%$ of the patients consulting a GP were also consulting a specialist, while patients consulting a specialist were usually not seeing a GP. Table lb shows the relationship between the presence of any disease and osteoporosis, categorized for numbers of diseases and their prevalences in an average general practice. Within the subgroups of women with more than one disease in categories $\mathrm{al}$ and $\mathrm{b} \backslash$ or more than two diseases in category $\mathrm{c}$, the prevalences of osteoporosis were statistically significant lower than the overall prevalence for all women $(\mathrm{OR}=0.70 ; \mathrm{CI}=0.49-0.99)$. Within the subgroups of women with more than one disease with prevalence over $1 \%$ in an average general practice (category al and in category cl) the prevalence of osteoporosis was statistically lower than the overall prevalence for all women ( $O R=0.68 ; C l=0.47-0.99)$. The prevalence of osteoporosis in women having one disease in category $\mathrm{bl}$ or two diseases $(1+1)$ in category $\mathrm{cl}$ was 
slightly higher than the overall prevalence for all diseased women $(\mathrm{OR}=1.41, \mathrm{Cl}=0.98$ 2.02). The prevalences of low BMD showed a similar trend (not shown in table $1 \mathrm{~b}$ ).

All 72 independent variables used in the regression analyses are summarized in table 2 . Of the 147 different diseases present in the study population only 16 had a prevalence over $1 \%$. Fourteen of the 183 different complaints and 24 of the 241 different drug treatments had a prevalence over $1 \%$ in general practice. $50 \%$ of all women mentioned the presence of low back pain, but all patients were systematically questioned on this item. Hypertension was a common disease, with a prevalence of $19 \%$. From the logistic regression analysis with all 72 variables (complete model) those variables significantly correlated with osteoporosis or low BMD (18), are given in table 3 Most of the comorbidity variables were found to be associated with a lower prevalence of osteoporosis. Among complaints, only cervical complaints and nervousness were significantly related to low BMD. Except for the use of systemic corticosteroids, all drug treatments dropped out. Among the variables which were not statistically significant (53) we made three clusters of clinically interrelated variables: cluster 1, disorders of the locomotor system (joint ache not otherwise classified plus osteoarthritis, sports at present, knee, hip, shoulder and muscle complaints, painful legs and use of nsaids); cluster 2, cardiovascular disorders (hypercholesterolaemia, peripheral arterial occlusive diseases, dysrhythmia, eva and tia); cluster 3 , therapy for cardiovascular disorders (betablockers, calcium antagonists, ace inhibitors, acetosal and anti-lipaemics). The results of the logistic regression analyses in which the different clusters were successively removed (reduced models) are shown in table 4. No statistically significant differences were found between the complete and the reduced models. Therefore, further analyses were done with the 18 variables from table 3 plus 'gastric surgery'. Gastric surgery was added because this variable is often mentioned in the literature in relation to osteoporosis and there was a statistically significant correlation with the presence of osteoporosis in our bivariate analyses. Table 5 shows the results of stepwise forward and backward logistic regression andyses with the 18 remaining independent variables. The analyses were performed for all patients, as well as for the subgroups Non-consulting-, GP-consulting and Specialist-consulting patients, and for both osteoporosis and low BMD. Finteen variables remained statistically significant in one or more subgroups. Six co-morbidity variables had atatistically stgnificant correlation with the presence of osteoporosis or low BMD. Thee of these (cervical complaints, gastric surgery and systemic use of corticosteroids) had a positive correlation with the presence of osteo-porosis or low $\mathrm{BMD}$, whereas 3 (nervousness, hypertension and angina pectoris) had negative correlation with the presence of asteoporosis.

Hypertension and angina pectoris showed a significant negative correlation with the presence of osteoporosis or low BMD in almost all subgroups. These two diseases are also clinically related. We therefore searched for a clinical or biological explanation of 
the possible protective effect of hypertension and angina pectoris against osteoporosis, in relation to the use of thiazide diuretics, since the latter are frequently prescribed to these patients. From table 6 can be seen that hypertension and angina pectoris are strongly correlated with the presence of obesity, irrespective of the use of thiazide diuretics ( $\mathrm{OR}=0.44, \mathrm{Cl}=0.34-0.57$ for hypertension and $\mathrm{OR}=0.46, \mathrm{CI}=0.31-0.69$ for angina pectoris). In the subgroups of patients with hypertension or angina pectoris the correlation between BMD and weight was found to be higher than in the total study population. The results were independent of age and duration of use.

The clinical significance of co-morbidity for the presence of osteoporosis or low BMD was assessed by extrapolating the results from the study population to an average general practice ( 396 women between 50 and 80 years of age per GP, see table 7). The average general practice includes 88 osteoporotic postmenopausal women aged 50-80 years; 44 in the subgroup with some disease and 44 in the subgroup without any disease. The GP will be familiar with the medical history of about 228 consulting patients. Of those patients, 51 are osteoporotic; 26 in the subgroup GP-consulting, 25 in the subgroup Specialist-consulting. In the Non-consulting subgroup $(\mathrm{n}=166) 36$ osteoporotic patients are "hidden'. Hence, in an average general practice, most osteoporotic patients are not known as such by the GP, whereas the opposite is true for the specialist. Using categories $b \backslash$ and $c \backslash$ from table $1 b, 13$ out of $48(26 \%)$ women in an average general practice are osteoporotic in the subgroups with one disease with a prevalence $<1 \%$. Compared with the subgroups containing patients with one disease with a prevalence higher than $1 \%$, the percentage of osteoporotic patients is $21 \%$ ( 21 out of 99). In conclusion, in an average general practice, the relationship between osteoporosis and co-morbidity is highest in those patients having just one relatively rare disease.

\section{Discussion}

An important reason for the present study was our previous and unexpected finding that the presence of a disease seemed to be somewhat protective against osteoporosis. The present study shows further evidence for this finding through the inverse relationship between the number of diseases present and the prevalence of osteoporosis and low BMD, a relationship that could not be explained by older age, lower BMI or any other biometrical or lifestyle variable(s). In accordance with this finding, the prevalences of osteoporosis and low BMD in the subgroup of Non-consulting women were higher than in the total study population.

The clinically most relevant co-morbidity variables were the systemic use of corticosteroids (CS) and gastric surgery. CS per os are more often prescribed by specialists (in the treatment of rheumatic patients, patients with COPD, etc) than in general practice, 
whereas inhaled CS are commonly used in daily general practice ${ }^{(14,15)}$. Despite its disappearance in the multivariate analyses, bivariate analysis between the use of inhaled $\mathrm{CS}$ and the presence of osteoporosis showed a statistically significant correlation $(\mathrm{OR}=2.5, \mathrm{CI}=1.2-3.2)$. The relatively recent introduction of inhaled $\mathrm{CS}$ may have caused the lack of definite evidence for a correlation with osteoporosis. Hence, the widespread use of inhaled CS seems to warrant further study, preferably in a prospective design. Gastric surgery can lead to decreased absorption of calcium and dietary vitamin D. This can lead to reduced bone mass. Gastric surgery is of greater importance in general practice than in a specialist setting, because after gastric surgery most patients are cured of their illness and therefore no longer consult a specialist. On the other hand, gastric surgery is generally less common today, so it can be expected that this co-morbidity variable as a 'predictor' of osteoporosis will gradually disappear in the near future. An unexpected co-morbidity variable positively related with the presence of osteoporosis or low BMD is that of cervical complaints. In the subgroup of Non-consulting patients, this factor had the highest significant correlation with the presence of osteoporosis. Having osteoporosis may be related to an increased kyphotic posture, causing cervical complaints. Our hypothesis that cervical complaints are related to loss of height could be rejected after an additional analysis. The mean loss of height between the present age and the age of 25 was $3.0 \mathrm{~cm}$ in each subgroup. Nervousness, which was negatively correlated with low BMD in the subgroup of Non-consulting patients, was not accompanied by high body weight or high BMI. Perhaps nervous women have a relatively high level of physical activity (other than sporting activities).

The remarkable 'protective' effect of hypertension and angina pectoris turned out to be independent of the use of thiazide diuretics. The mean body weight of the patients with hypertension or angina pectoris was 5-10\% above the mean weight of the total study population, explaining an important part of the higher BMD in cardiovascularly compromised patients. Since we could not find a pathophysiological concept explaining this relationship, weight must be the actual 'predictor'. These findings contrast with those by Morton et al ${ }^{(16)}$. However, it should be noted that the study populations were very different (prevalence of thiazide users $5 \%$ versus $25 \%$, mean age 64 versus 73 years and mean BMI 28.1 versus 25.5 for our unselected study population versus the population studied by Morton et al). In most subgroups, the use of hormones (other than contraceptive pills) for more than 5 years appeared to be "protective" against low BMD but not against osteoporosis (table 5). This is in accordance with the fact that the prevalence of osteoporosis is higher in the elderly. Contrary to what has been found in many other studies, a history of recent clinical fractures was positively associated with low BMD but not with osteoporosis. This contradiction might be due to the fact that in most other studies the populations investigated were selected with respect to the 
presence of risk factors potentially linked to osteoporosis.

The results of our cross-sectional study should be confirmed by a prospective study, preferably in a GP setting. However, the present study already had a longitudinal aspect, since each disease and disease-related complaint results from a disease specific course. We decided to study a random sample in which the proportions of diseased and healthy women were similar to those in any unselected population of postmenopausal women aged 50-80. With respect to the prevalence of co-morbidity, our data could be compared with those from two Dutch registration networks for morbidity in general practice ${ }^{(8,17)}$. These networks use data derived from morbidities presented by consulting patients, which means the data are comparable with those from our sample of consulting patients.

In conclusion, the clinical relevance of co-morbidity for detecting osteoporosis or low BMD in dailly general practice is limited. Co-morbidity is important with respect to patient care but useless in screening elderly female populations for the presence of osteoporosis. Either the incidence of the relevant complaints, diseases and drug use, or the relevant percentages of osteoporotic patients are too low. However, all people using CS and all patients with gastric surgery in their history should be checked for the presence of low BMD. Case-finding might be helped by asking consulting patients for the presence of cervical complaints: Cardiovascular disorders are often associated with relatively high $\mathrm{BMD}$. Therefore, searching for osteoporosis in this category is less useful. 
Table 1a. Retationship between the presence of $0,1,2$ or more diseases and the presence of osteoporosis and low BMD, categorized for all patients(n 1684): Non-consulting GP consulting and Spettalist consulting pattents

\begin{tabular}{|c|c|c|c|c|c|c|c|c|c|c|c|c|}
\hline \multirow[t]{3}{*}{ 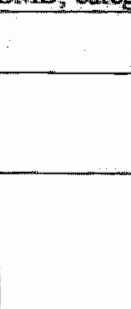 } & \multirow{2}{*}{\multicolumn{3}{|c|}{ Allpatients }} & \multicolumn{9}{|c|}{ Conswling behomior } \\
\hline & & & & \multicolumn{3}{|c|}{$\begin{array}{l}\text { Non-consulting } \\
\text { patientis }\end{array}$} & \multicolumn{3}{|c|}{$\begin{array}{l}\text { Gp-conswlring } \\
\text { patients }\end{array}$} & \multicolumn{3}{|c|}{$\begin{array}{l}\text { Specialist-conwhing } \\
\text { pathents }\end{array}$} \\
\hline & $N^{*}$ & $\begin{array}{l}\% \\
\text { ostro- } \\
\text { porosis }\end{array}$ & $\begin{array}{l}\% \\
\text { low } \\
\text { BMD }\end{array}$ & $\mathrm{N}^{*}$ & $\begin{array}{l}\% \\
\text { osteo- } \\
\text { porosiis }\end{array}$ & $\begin{array}{l}\% \\
\text { low } \\
\text { BMD }\end{array}$ & $\mathrm{N}^{*}$ & $\begin{array}{l}\text { osteo- } \\
\text { porrosis }\end{array}$ & $\begin{array}{l}\text { Oow } \\
\text { BMD }\end{array}$ & $\mathbf{N} *$ & $\begin{array}{l}\% \\
\text { osteo- } \\
\text { ponosis }\end{array}$ & $\begin{array}{l}\% \\
\text { low } \\
\text { BMD }\end{array}$ \\
\hline & 1680 & $22 \%$ & $62 \%$ & 702 & $22 \%$ & $65 \%$ & 531 & $21 \%$ & $58 \%$ & 443 & $23 \%$ & $60 \%$ \\
\hline disconsed & & & & & & & & & & & & \\
\hline mo & 790 & $23 \%$ & $64 \%$ & 646 & $24 \%$ & $65 \%$ & 53 & $23 \%$ & $64 \%$ & 91 & $20 \%$ & $54 \%$ \\
\hline yes & 890 & $21 \%$ & $60 \%$ & 56 & $9 \%$ & $66 \%$ & 478 & $20 \%$ & $58 \%$ & 352 & $24 \%$ & $62 \%$ \\
\hline $\begin{array}{c}1 \\
\text { disease }\end{array}$ & 553 & $22 \%$ & $61 \%$ & 51 & $8 \%$ & $63 \%$ & 282 & $22 \%$ & $57 \%$ & 216 & $26 \%$ & $66 \%$ \\
\hline $\begin{array}{c}2 \\
\text { diseases }\end{array}$ & 233 & $21 \%$ & $60 \%$ & 4 & $25 \%$ & $100 \%$ & 146 & $19 \%$ & 599 & 83 & $23 \%$ & 590 \\
\hline $\begin{array}{l}>2 \\
\text { diseases }\end{array}$ & 104 & $15 \%$ & $56 \%$ & $I$ & $0 \%$ & $100 \%$ & 50 & $14 \%$ & 5800 & 53 & $17 \%$ & $53 \%$ \\
\hline
\end{tabular}

$4 \mathrm{~N}=1680$ (column) and 1676 (row) instead of 1684 due to missing values (4 subjects for diseased or not; 8 subjects for consulting behaviour). 
Table Ib. Relationship between presence of any disease and osteoporosis. Diseases are categorized according its prevalence in an average oP-practice $(\mathrm{C1} \%, \leq 1 \%)$. Numbers of patients are given.

\begin{tabular}{|c|c|c|c|c|c|}
\hline Patients with: & \multicolumn{2}{|c|}{ Osteoporasis } & \multirow[t]{2}{*}{ total } & & \\
\hline $\begin{array}{l}\text { a one ar more diseases with } \\
\text { prevontences } 19\end{array}$ & Yes & Mo & & \multicolumn{2}{|c|}{ patients with mone than one disease } \\
\hline I disease & 89 & 331 & 420 & $\mathbf{n}$ & $\%$ osteoporosis (n) \\
\hline 2 discases & 26 & 110 & 136 & 136 & \\
\hline 3 diseases: & 6 & 36 & 42 & 42 & \\
\hline 4 diseases & 0 & 8 & 8 & 8 & \\
\hline 5 disuases : & 0 & 1 & 1 & 1 & \\
\hline subtotal & 121 & 486 & 607 & 187 & $17 \%(32)$ \\
\hline $\begin{array}{l}\text { bl one or more diseases whith } \\
\text { prewalencer } 1 \%\end{array}$ & & & & \multicolumn{2}{|c|}{ patients with more them one disease } \\
\hline 1 disease & 34 & 99 & 133 & $\mathrm{n}$ & $\%$ asteoporosis (n) \\
\hline 2 diseases & 4 & 117 & 21 & 21 & \\
\hline 3 diseases & $\mathbb{1}$ & 3 & 4 & 4 & \\
\hline subtotal & 39 & 119 & 158 & 25 & $20 \%$ (5) \\
\hline $\begin{array}{l}\text { ch one ot more diseases in both } \\
\text { calegorles }\end{array}$ & & & & \multicolumn{2}{|c|}{ patients with more than two diseases } \\
\hline$a l+b l l$ diseases & 20 & 57 & 77 & $\underline{\mathbf{n}}$ & $\%$ osteoporasis (n) \\
\hline $2+1$ discases & 4 & 21 & 25 & 25 & \\
\hline $3 * 1$ diserases & 0 & 5 & 5 & 5 & \\
\hline 441 diseases & $1:$ & 0 & $\ldots$ & 1 & \\
\hline $1+2$ diseases: & 3 & 12 & 15 & 15 & \\
\hline $2+2$ diseases & 0 & 2 & 2 & 2 & \\
\hline subtotial & 28 & 97 & 125 & 48 & $17 \%(8)$ \\
\hline diseased & 188 & 702 & 890 & \multirow{3}{*}{\multicolumn{2}{|c|}{$\begin{array}{l}890 \text { patients with } 1341 \text { diseases } \\
\text { a/ } 15 \text { different diseases } \\
\text { b/ } 132 \text { different diseases }\end{array}$}} \\
\hline not diseased & 184 & 606 & 790 & & \\
\hline all study patiwns: total & 372 & 1308 & $1680^{\circ}$ & & \\
\hline
\end{tabular}

* 1680 instead of 1684 due to missing values (see table la) 
Table 2. Independent variables issed in regnession analyses. Numbers derived fiom the total study popullation (N=1684) biometrical and lifestyle factors and medical history

\begin{tabular}{|c|c|c|c|c|c|c|c|}
\hline $\mathrm{n}$ & $\begin{array}{l}\text { from previous study: } 24 \\
\text { wariables }\end{array}$ & $n$ & complaimis & $n$ & dispetsies & $n$ & derg-urewnews \\
\hline 1014 & age, over 60 years & 851 & $\begin{array}{l}\text { presence of low } \\
\text { back pain }\end{array}$ & 321 & hypertension & 127 & buttablockers \\
\hline 893 & $\begin{array}{l}\text { body weight } \\
\text { less than } 70 \mathrm{~kg}\end{array}$ & 55 & $\begin{array}{l}\text { joint ache not other } \\
\text { wise classfifed }\end{array}$ & 128 & osteourthmis * * & 94 & calciun antagonists \\
\hline 759 & $\begin{array}{l}\text { body height, } \\
\text { less than } 160 \mathrm{~cm} \text { : }\end{array}$ & 50 & cervical complaints & 115 & $\mathrm{DD}+\mathrm{NDD}$ Diabetes $\mathrm{M}$ & 76 & ace miluibritors \\
\hline 896 & BMI, below $27 \mathrm{~kg} / \mathrm{m}^{2}$ & 49 & gastric complaints & 109 & hypercholesterohemia & 70 & actosal $80 / 100 \mathrm{mg}$ \\
\hline 138 & $\begin{array}{l}\text { any clinical fracture } \\
\text { during past } 5 \text { years }\end{array}$ & 42 & knee complaints & 108 & $\begin{array}{l}\text { angina pectoris } \\
\text { present }\end{array}$ & 69 & ristids \\
\hline 890 & presence of any disease & 318 & berdache & 71 & $\begin{array}{l}\text { connedive tissue } \\
\text { disseases }\end{array}$ & 57 & oral anti-diabetios \\
\hline 258 & $\begin{array}{l}\text { Use of the pill for } \\
\text { more than } 5 \text { years }\end{array}$ & 36 & nervousness & 61 & COPD & 57 & anti-lipaemics \\
\hline 85 & $\begin{array}{l}\text { use of hormomes for } \\
\text { more than } 5 \text { years }\end{array}$ & 34 & hip complaints & 53 & $\begin{array}{l}\text { breast cancer in } \\
\text { history }\end{array}$ & 53 & $\begin{array}{l}\text { analgetics (aspirin + } \\
\text { paracetamol) }\end{array}$ \\
\hline 249 & ovariectomy in history & 33 & shoulder complaints & 33 & hypothyroidism & 50 & nitrates \\
\hline 577 & hysterectomy in history & 25 & muscle complaints & 29 & $\begin{array}{l}\text { peripheral anterial } \\
\text { occhusive disenses }\end{array}$ & 49 & loop diuretics \\
\hline 503 & $\begin{array}{l}\text { menopause } \\
\text { under the age of } 45\end{array}$ & 25 & steep disonders & 28 & gastuic disorders & 49 & thinzide diuretics \\
\hline 963 & less than 35 fertile years & 22 & tirediness & 25 & dyarmythria & 46 & sympaticomimetics \\
\hline 797 & more than two children & 21 & painfull legs & 25 & ovaltia in history & 43 & $\begin{array}{l}\text { k-sparing + thiazide } \\
\text { diumetic combination }\end{array}$ \\
\hline 453 & $\begin{array}{l}\text { perimenopausal } \\
\text { complaints in history }\end{array}$ & 17 & $\begin{array}{l}\text { disturbance of } \\
\text { equilibrium }\end{array}$ & 24 & $\begin{array}{l}\text { myocardial intarction } \\
\text { in history }\end{array}$ & 41 & instilin \\
\hline 189 & $\begin{array}{l}\text { positive family history of } \\
\text { osteoporotic fractures }\end{array}$ & & & 22 & hyperthyroidism & 38 & thyreomimetics \\
\hline 1600 & coffee intake & & & 19 & $\begin{array}{l}\text { gastinc surgery in } \\
\text { history }\end{array}$ & 32 & $\begin{array}{l}\text { corticosteroids, non- } \\
\text { systemic }\end{array}$ \\
\hline 593 & alcohol intake & & & & & 30 & anticoagullants \\
\hline 465 & smoking & & & & & 27 & $\begin{array}{l}\text { ace inhibitors ot tha de } \\
\text { diutetics }\end{array}$ \\
\hline 236 & $\begin{array}{l}\text { calcium intake, } \\
\text { less than } 500 \mathrm{mg}\end{array}$ & & & & & 22 & cardiac glycosides \\
\hline $\begin{array}{r}214 \\
1412 \\
58 \\
\end{array}$ & $\begin{array}{c}\text { occupational exercise } \\
3 \text { categonies mild } \\
\text { moderate } \\
\text { heavy }\end{array}$ & & & & & 20 & $\begin{array}{l}\text { thiaride + } \mathrm{K} \text {-sparing } \\
\text { dinaretic }\end{array}$ \\
\hline 577 & $\begin{array}{l}\text { no sporting activities } \\
\text { at present }\end{array}$ & & & & & 20 & benzodiazepines \\
\hline 595 & $\begin{array}{l}\text { no sporting activities in } \\
\text { the past }\end{array}$ & & & & & 17 & antidepresisturts \\
\hline \multirow{2}{*}{\multicolumn{6}{|c|}{$\begin{array}{l}\text { mild and modierate were used as one combined variable in the regression analyses } \\
\text { joint ache not otherwise classified and osteoarthritis were used as one combined variable } \\
\text { in the regression analyses } \\
\text { thiazide -containing diuretics and combinations with ofher medications were used as one } \\
\text { combined variable in the regression analyses. }\end{array}$}} & 16 & $\begin{array}{l}\text { betablocker thidede } \\
\text { diuretic }\end{array}$ \\
\hline & & & & & & 14 & $\begin{array}{l}\text { conticosteroids, } \\
\text { systemic }\end{array}$ \\
\hline
\end{tabular}




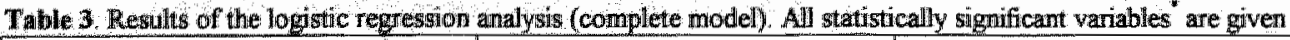

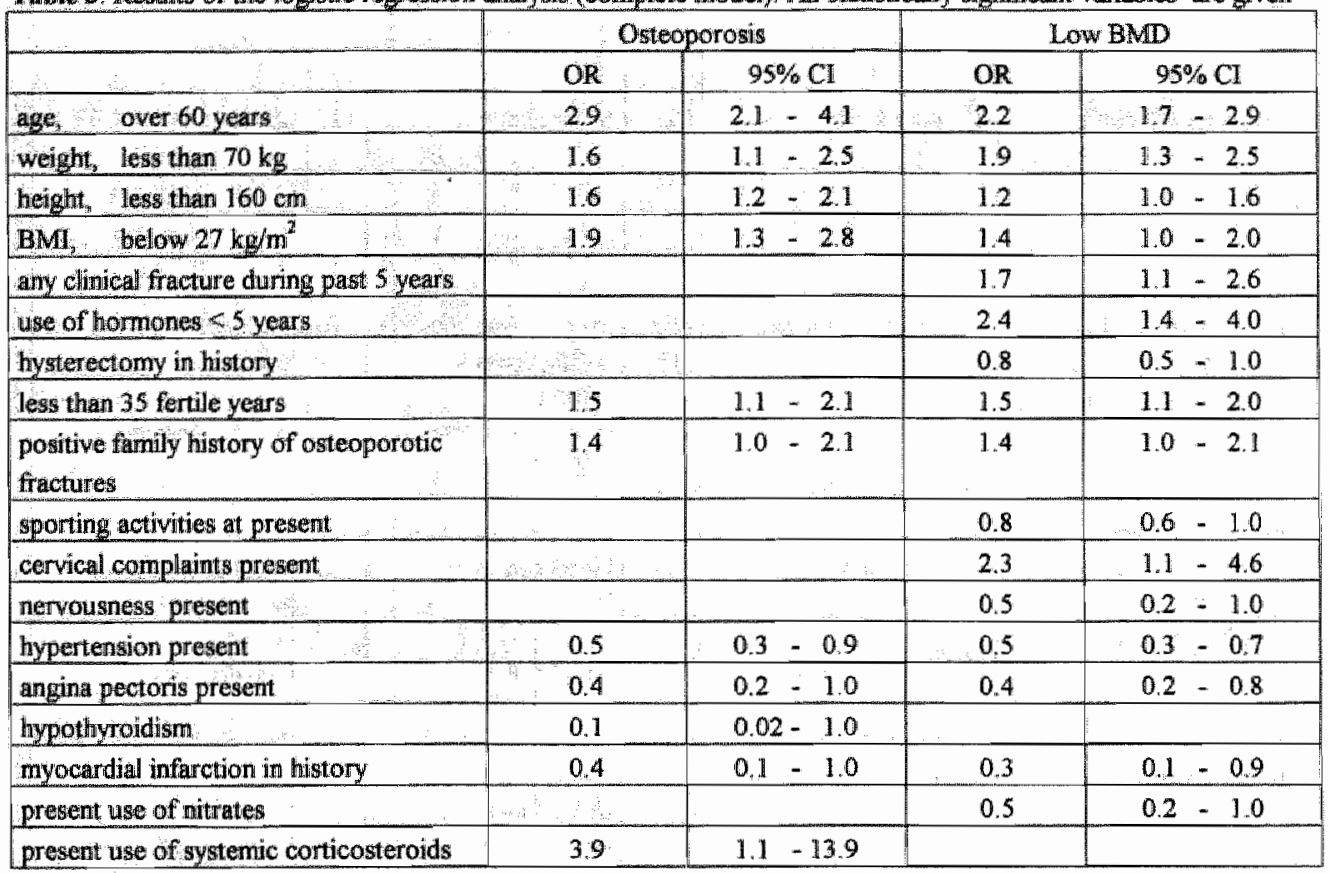

* All percentages are rounded off; it should be noted that ' 1.0 " lies within the significant range.

Table 4. Results of the logistic regression analyses after exclusion of the various clusters (reduced models)

\begin{tabular}{|c|c|c|c|c|c|}
\hline & Loglikelihood & $\begin{array}{l}\text { Difference between complete } \\
\text { model and reduced model }\end{array}$ & $\begin{array}{l}\text { Chi - square } \\
\text { (difference } \times 2 \text { ) }\end{array}$ & $\mathrm{D}_{\mathrm{F}} \mathrm{F}$ & p-value \\
\hline \multicolumn{6}{|l|}{ Osteoporosis } \\
\hline complete model & -710.654 & & & & \\
\hline custer 1 excluded & $-713,414$ & 2.760 & 5520 & 8 & $0,25-0,50$ \\
\hline chister 2 exchuded & -711.255 & 0.601 & 1202 & 4 & $0,10-0,25$ \\
\hline duster 3 exchuded & -712.759 & 2.105 & 4210 & 6 & $0,25-0,50$ \\
\hline \multicolumn{6}{|l|}{ Low BMD } \\
\hline complete model & -918.878 & & & & \\
\hline chuster 1 excluded & -922.211 & 3.333 & 6.666 & 8 & $0,25-0,50$ \\
\hline cluster 2 excluded & -920.828 & 1.950 & 3.900 & 4 & $0,50-0,75$ \\
\hline cluster 3 excluded & -920.780 & 1.902 & 3.804 & 6 & $0,25-0,50$ \\
\hline
\end{tabular}

Cluster I with the variables joint ache plus osteoarthnitis, sports at present, knee, hip, shoulder, muscle complaints, painful legs and use of nsaids.

Cluster 2 with the variables hypercholesterolaemia, peripheral arterial occlusive diseases, arythmia, cva and tia. Cluster 3 with the variables betablockers, calcium antagonists, ace inhibitors, acetosal and anti-lipaemics. 


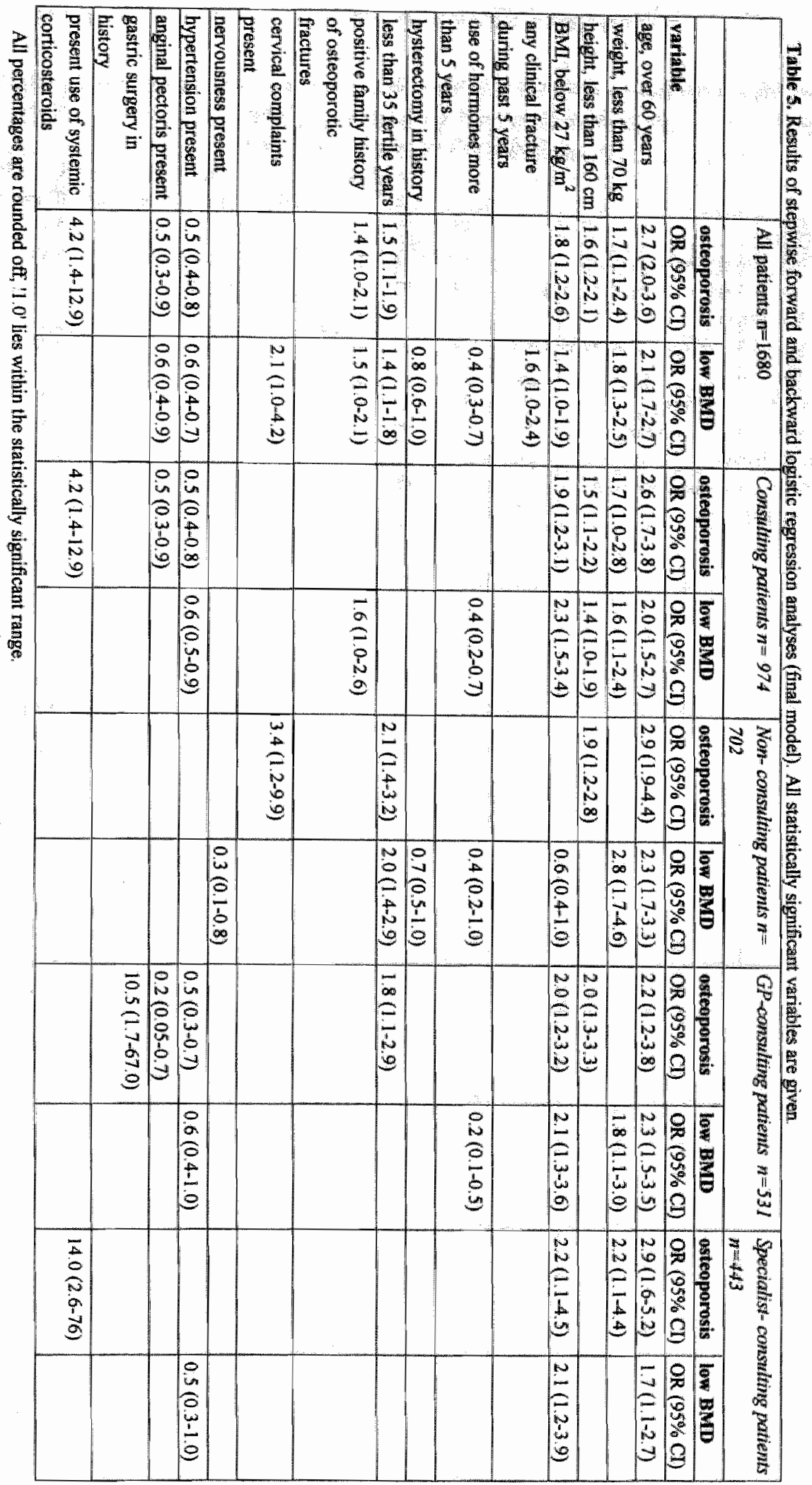


Table 6. Correlations between BMD and body weight in relation to the use of thiazide diuretics, studied in the subgroups of patients with hypertension and patients with anginal complaints.

\begin{tabular}{|c|c|c|c|c|}
\hline \multicolumn{5}{|c|}{ Study population contains 1684 patients } \\
\hline 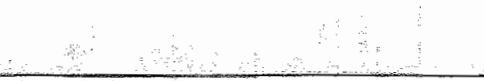 & N & $\begin{array}{l}\text { mean BMD } \\
\left(\mathrm{g} / \mathrm{cm}^{2}\right)(\mathrm{SD})\end{array}$ & $\begin{array}{l}\text { mean weight } \\
(\mathrm{kg}) \text { (SD) }\end{array}$ & $\begin{array}{l}\text { coefficient of correlation } \\
\text { between BMD and weight }\end{array}$ \\
\hline All patients & 1684 & $10.93 \quad(0.17)$ & $70.9 \quad(12.0)$ & 0.36 \\
\hline Patients with anginal complotinits & 108 & $(0.20)$ & $75.9 \quad(14.2)$ & 0.55 \\
\hline $\begin{array}{l}\text { Patients with anginal complaints using } \\
\text { thiazide diuretics }\end{array}$ & 22 & $(0.19)$ & $78.8 \quad(12.2)$ & 0.63 \\
\hline $\begin{array}{l}\text { Patients with anginal complaints not using } \\
\text { thiazide diuretics }\end{array}$ & 86 & $1.00 \quad(0.20)$ & $75.2(14.7)$ & 0.53 \\
\hline Hyperiensive patiens & 321 & $(0.17)$ & $74.7 \quad(12.9)$ & 0.42 \\
\hline $\begin{array}{l}\text { Hypertensive patients using } \\
\text { thiazide diuretics }\end{array}$ & 92 & $1.00 \quad(0.18)$ & $74.0 \quad(13.4)$ & 0.38 \\
\hline $\begin{array}{l}\text { Hypertensive patients not using } \\
\text { thiazide diuretics. }\end{array}$ & 229 & $0.98 \quad(0.17)$ & $75.0 \quad(12.7)$ & 0.45 \\
\hline
\end{tabular}


Table 7. Releyance of co-morbidity for the presence of osteoporosis in daily general practice Extrapolated from study population to an average GP-practice.

\begin{tabular}{|c|c|c|c|c|c|c|c|}
\hline \multirow{2}{*}{ 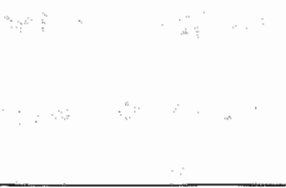 } & \multirow[t]{2}{*}{$\begin{array}{l}\text { All patients } \\
\mathrm{n}=396^{*}\end{array}$} & \multicolumn{2}{|c|}{$\begin{array}{l}\text { Mon-conuswltingy } \\
\text { patients } n=166\end{array}$} & \multicolumn{2}{|c|}{$\begin{array}{l}\text { GP-eonsulting } \\
\text { patients } n=124\end{array}$} & \multicolumn{2}{|c|}{$\begin{array}{l}\text { Specialisit-conswl } \\
\text { tixy partients } n=104\end{array}$} \\
\hline & & n & $\begin{array}{l}\text { osteoporotic } \\
\text { patients }\end{array}$ & $\mathrm{n}$ & $\begin{array}{l}\text { osteoporotic } \\
\text { patients }\end{array}$ & $\mathrm{n}$ & $\begin{array}{l}\text { osteoporotic } \\
\text { patients }\end{array}$ \\
\hline diseased NO & 185 & 152 & 36 & 12 & 3 & 21 & 5 \\
\hline YES & 209 & 14 & 1 & 112 & 23 & 83 & 20 \\
\hline 1 disease & 130 & 12 & $I$ & 66 & 14 & 51 & 13 \\
\hline 2 disease & 55 & 1 & 0 & 34 & 7 & 20 & 5 \\
\hline$>2$ diseases & 24 & 1 & 0 & 12 & 2 & 12 & 2 \\
\hline age, over 60 years & 238 & 81 & 25 & 88 & 20 & 69 & 20 \\
\hline weight, less than $70 \mathrm{~kg}$ & 210 & 95 & 27 & 59 & 18 & 55 & 18 \\
\hline height, less than $160 \mathrm{~cm}$ & 179 & 68 & 21 & 64 & 17 & 47 & 12 \\
\hline BMI, below $27 \mathrm{~kg} / \mathrm{m}^{2}$ & 210 & 98 & 29 & 56 & 17 & 57 & 17 \\
\hline $\begin{array}{l}\text { any clinical firacture } \\
\text { during past } 5 \text { years }\end{array}$ & 32 & 11 & $4=$ & 10 & 3 & 10 & 3 \\
\hline $\begin{array}{l}\text { use of hormones } \\
\text { more than } 5 \text { years }\end{array}$ & 20 & 7 & 1 & 6 & $\begin{array}{r}1 \\
\end{array}$ & 7 & 1 \\
\hline bystereetomy in history & 135 & 48 & 9 & 45 & 8 & 41 & 9 \\
\hline $\begin{array}{l}\text { less than } 35 \text { fertile } \\
\text { years }\end{array}$ & 226 & 93 & 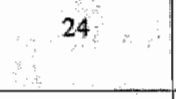 & 68 & 17 & 65 & 14 \\
\hline $\begin{array}{l}\text { positive family history } \\
\text { of osteoporotic } \\
\text { fractures }\end{array}$ & 44 & 18 & 4 & 14 & 3 & 12 & 4 \\
\hline $\begin{array}{l}\text { cervical complaints } \\
\text { present }\end{array}$ & 12 & 4 & $\|-2$ & 5 & 2 & 3 & $1-2$ \\
\hline nerwousness present & 8 & 3 & 1 & 3 & $0-1$ & 2 & $0-1$ \\
\hline hypertension present & 75 & 1 & 0 & 61 & 9 & 13 & 3 \\
\hline angina pectoris present & 26 & 0 & 0 & 10 & 1 & 16 & 3 \\
\hline $\begin{array}{l}\text { present use of systemic } \\
\text { corticosteroids }\end{array}$ & 3 & 0 & 0 & 1 & $0-1$ & 2 & $1-2$ \\
\hline $\begin{array}{l}\text { gastric surgery in } \\
\text { history }\end{array}$ & 5 & 1 & 0 & 2 & 1 & 2 & $0-1$ \\
\hline
\end{tabular}

* 2 missing values for consulting behavior. 


\section{REFERENCES}

1. Riges BL, Melton LJ. The worldwide problem of osteoporosis: Insights afforded by epidemiology. Bone 1995;17:505s-11s

2. Khosla S Melton LJ IIL Secondary osteoporosis. In Riggs BL, Melton LJ III Osteoporosis: etiology, diagnosis and management Philadelphia Lippincott-Raven, 1996

3 Raisz LG. Secondary osteoporosis. In: Osteoporosis 1996. Proceedings of the 1996 World Congress on Osteoporosis. Papapoulos SE, Lips $P$, Pols HAP, Johnston CC, Delmas PD, Editors. Amsterdam:Elsevier Science BV, 1996; 339-99

4. Reid DM. Secondary osteoporosis. Baillieres Clin Endocrinol Metab 1997;11(1):83-99

5. Cummings S. Risk factors for hip fracture in white women. N Engl J Med 1995;332:767-772

6. Moknight $\mathrm{A}$, Steele $\mathrm{K}_{\mathrm{w}}$ Millis $\mathrm{K}$, Gilchrist $\mathrm{C}$, Taggart $\mathrm{H}$. Bone mineral density in relation to medical and lifestyle risk factors for osteoporosis in premeropausal, menopausal and postmenopausal women in general practice. Br J Gen pract 1995;45:317-20

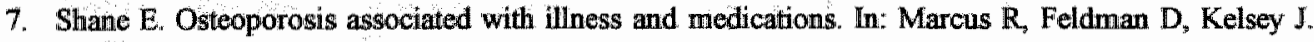
Osteoporosis. Sam Diego:Academic Press, 1996;925-46

8. Van de Lisdonk EH, Van den Bosch WJM, Huygen FJA, Lagro-Jansen ALM. Ziekten in de buisartspraktijk. Utrecht: Bunge, 1990

9. Van der Voort DJM, Dinant GJ, Rinkens PELM, Van der Voort-Duindam CJM, Van Werseh JWJ, Geusens PP. Diagnositic accuracy of an algorytm for quick detection of patients with low bone mineral density in everyday general practice. Accepted for Journal of Clinical Epidemiology.

10. Dixon WJ, Brown MB, Engelman L, Holl MA, Jenrich RI. BMDP statistical software manual. Berkeley: University of Calefornia Press, 1990

11. Assessment of fracture risk and its application to screening for postmenopausal osteoporosis. Geneva:WHO Technical report series 843, 1994

12. Bone Density Reference Data. Bruxulles:S.A. Hologic Europe,

13. Steiger $P$, Cummings SR, Black DM, Spencer NE, Genant HK. Agerelated decrements in bone mineral density in women over 65. J Bone Miner Res 1992;7:625-32

14. Laan RFJM, Riel PLCM Van, Putte LBA Van de, Erning LJThO Van, Hof MA Van "t, Lemmens JAM. low-dose prednisone induces rapid reversible axial bone loss in patients with rheumatoid arthritis. Ann Intern Med 1993;119:963-68

15. Woodcock A. Effects of inhaled corticosteroids on bone density and metabolism. J Allergy Clin Immunol 1998;101:S456-59

16. Morton DJ, Barrett-Connor EL, Edelstein SL. Thiazides and bone mimeral density in elderly men and women. Am J Epidem 1994;139:1107-15

17. Metsemakers JFM, Höppener $P$, Knottnerus JA, Kocken RJJ, Liomonard CBG. Computerize health information in The Netherlands: a registration network of family practices. $\mathrm{Br} J$ Gen Pract $1992 ; 42: 102-6$ 


\subsection{Samenvatting}

Doel van de studie. Het bepalen van de relatie tussen osteoporose en aanwezige ziekten, van de relatie tussen osteoporose en aan ziekten gerelateerde klachten en van de relatie tussen osteoporose en medisch-farmacologische behandeling (hierna te noemen 'co-morbiditeit'). Tevens willen we bepalen in welke mate de gevonden relaties kunnen worden gebruikt voor het opsporen van osteoporose in de dagelijkse praktijk.

Studie design. Cross-sectionele studie.

Patiënten en methoden. We gebruikten een aselecte steekproef uit de totale populatie vrouwen van 50-80 jaar in 12 huisartspraktijken, waarin totaal 23 huisartsen werkzaam zijn. Van deze vrouwen werden het gewicht, de lengte, de body mass index (BMI) en de botmineraaldichtheid (BMD) van de wervelkolom gemeten. De vrouwen vulden een anamneselijst in met vragen die betrekking hadden op mogelijk oorzaken van osteoporose (zoals leefwijze, het vroegere gewicht en hun lengte). De anamneselijst ging in detail in op hun medische geschiedenis, op de aanwezigheid van ziekten, klachten en het gebruik van medicatie.

Statistiek. Osteoporose werd gedefinieerd als een $\mathrm{BMD}$ in $\mathrm{gr} / \mathrm{cm}^{2}$ van de lumbale wervelkolom (L2-4) van meer dan 2,5 SD onder de gemiddelde BMD van de jong volwassen vrouw, de lage botmineraaldichtheid werd gedefinieerd als een BMD van meer dan $1 \mathrm{SD}$ onder dat gemiddelde (respectievelijke afkappunten 0,800 en $0,970 \mathrm{gr} / \mathrm{cm}^{2}$ ). Alle analyses werden uitgevoerd voor de totale studiepopulatie en voor de subgroepen 'Non-consulting, 'GP-consulting' and 'Specialist-consulting' patiënten. Kruistabellen werden gemaakt om de relatie te beschrijven tussen het aanwezig zijn van een of meer ziekten en de aanwezigheid van osteoporose of een lage botmineraaldichtheid. De multivariabele logistische regressieanalyse met de $\mathrm{BMD}$ als afhankelijke variabele, werd verricht met 48 variabelen met betrekking tot co-morbiditeit en 24 variabelen met betrekking tot de biometrie en leefwijze (het complete model). Nadat was nagegaan of er van maskering sprake was werden de analyses herhaald met alle statistisch significante onafhankelijke variabelen uit het complete model (het gereduceerde 'final' model). Ten slotte maakten we een schatting van de klinische significantie van de resultaten door te berekenen hoeveel osteoporotische patiënten konden worden gedetecteerd door gebruik te maken van de resultaten van het gereduceerde model.

Resultaten. De verschillen in prevalentie van osteoporose en een lage BMD tussen de subgroepen met en zonder ziekten waren niet significant $(\mathrm{OR}=1,13 ; \mathrm{Cl}=0,9-1,42$ voor osteoporose; $\mathrm{OR}=1,19 ; \mathrm{Cl}=0,97-1,44$ voor een lage $\mathrm{BMD}$ ). Ook de verschillen in prevalentie van osteoporose en een lage BMD tussen de 'GP-consulting' en 'Specialist-consulting' categorieën waren niet significant $(\mathrm{OR}=0,84, \mathrm{CI}=0,62-1,14$ voor osteoporose; $\mathrm{OR}=0,92, \mathrm{Cl}=0,71-1,18$ voor een lage $\mathrm{BMD}$ ). De aanwezigheid van meer dan éen ziekte leek te zijn geassocieerd met een lagere prevalentie van osteoporose dan de aanwezigheid 
van één ziekte; het verschil was echter niet significant $(\mathrm{OR}=0,81, \mathrm{Cl}=0,60-1,09$ voor osteoporose; $\mathrm{OR}=0,85 ; \mathrm{Cl}=0,66-1,08$ voor lage $\mathrm{BMD}$ ). In alle categorieen (Non-consulting', 'GP-consulting' en 'Specialist-consulting') bleken de subgroepen met de hoogste aantallen ziekten het laagste percentage vrouwen met osteoporose of een lage BMD te bevatten. Deze trend was consistent maar niet statistisch significant. In de subgroepen van vrouwen met meer dan eén ziekte met een prevalentie van meer dan $1 \%$ in een gemiddelde huisartspraktijk was de prevalentie van osteoporose significant lager dan de prevalentie van osteoporose in de totale studiepopulatie $(\mathrm{OR}=0,68, \mathrm{CI}=0,47-0,99)$. De prevalentie van osteoporose onder de vrouwen met een ziekte met een prevalentie onder de $1 \%$ was iets hoger dan de prevalentie van osteoporose onder alle zieke vrouwen $(\mathrm{OR}=1,41$; $\mathrm{Cl}=0,98-2,02$ ). Slechts zes co-morbiditeit variabelen vertoonden een statistisch significante correlatie met de aanwezigheid van osteoporose of een lage BMD. Positieve correlaties werden gevonden tussen het gebruik van corticosteroïden per os (CS) en osteoporose onder alle patiënten $(\mathrm{OR}=4,2 ; \mathrm{CI}=1,4-12,9)$, tussen een maagoperatie in de voorgeschiedenis en osteoporose onder de 'GP-consulting' patiënten ( $O R=10,5 ; \mathrm{Cl}=1,7-67,0)$ en tussen nekklachten en osteoporose onder de 'Non-consulting' patiënten ( $O R=3,4$; $\mathrm{Cl}=1,2-9,9)$. Negatieve correlaties werden gevonden tussen nerveusiteit en een lage $\mathrm{BMD}$ onder de 'Non-consulting' patiënten $(\mathrm{OR}=0,3 ; \mathrm{Cl}=0,1-0,8)$, tussen hypertensie en osteoporose onder alle patiènten $(\mathrm{OR}=0,5 ; \mathrm{Cl}=0,4-0,8)$ en tussen angina pectoris en osteoporose onder alle patiënten $(\mathrm{OR}=0,5, \mathrm{Cl}=0,3-0,9)$. Het gebruik van thiazide diuretica door patienten met hypertensie of angina pectoris had geen significante invloed op de BMD.

Een gemiddelde huisartspraktijk bevat 88 osteoporotische postmenopauzale vrouwen in de leeftijd van 50-80 jaar: 44 in de subgroep met één of meer dan één ziekte en eveneens 44 in de subgroep zonder ziekte. De huisarts kent de medische geschiedenis van circa 228 postmenopauzale 'consulting' patiënten tussen de 50 en 80 jaar. Van deze patiënten zijn er 51 osteoporotisch: 26 in de subgroep 'GP-consulting' en 25 in de subgroep 'Specialistconsulting'. De subgroep 'Non-consulting' ( $\mathrm{n}=166)$ bevat 36 'verborgen' osteoporotische patiènten. Derhalve zijn in de gemiddelde huisartspraktijk de meeste osteoporotische patiènten als zodanig onbekend.

Conclusie. In de dagelijkse praktijk is de klinische relevantie van co-morbiditeit voor wat betreft de detectie van osteoporose of een lage BMD beperkt. Co-morbiditeit is belangrijk met betrekking tot de patientenzorg maar is niet zinvol te gebruiken om de oudere vrouwelijke bevolking te screenen op de aanwezigheid van osteoporose. Of de incidentie van relevante klachten, ziekten of het gebruik van medicatie is te laag of het percentage osteoporotische patiènten is te laag. Echter, alle patiēnten die corticosteroïden gebruiken en alle patienten met een maagoperatie in de voorgeschiedenis moeten worden onderzocht op de aanwezigheid van osteoporose. Case-finding kan bevorderd worden door te vragen naar de aanwezigheid van nekklachten. Cardiovasculaire ziekten zijn vaak gerelateerd aan een relatief hoge BMD. Het zoeken naar osteoporose in deze categorie patiënten 


\section{Hoofdstuk 6}

Risk factors for osteoporosis in relation to fractures.

Authors

1. D.J.M. van der Voort, MD, general practitioner (1)

2. P.P. Geusens, $\mathrm{MD}, \mathrm{PhD}$, professor of Rheumatology (2)

3. G.J. Dinant, $\mathrm{MD}, \mathrm{PhD}$, professor of Clinical Research in General Practice (1)

(1): University of Maastricht, Department of General Practice and Research Institute for Extramural and Transmural Health Care, Maastricht, The Netherlands

(2): Department of Internal Medicine, University Hospital, Maastricht, The Netherlands

Submitted 


\section{ABSTRACT}

Objective: To determine to what extent easily obtainable bone mineral density (BMD)related risk factors are predictors of the occurrence of fractures and to what extent changes in these determinants during a patient's lifetime are relevant.

Design: Cross-sectional population based study.

Subjects: 4725 postmenopausal women, 50-80 years of age, registered with 23 general practitioners (GPs)

Measurements: The women were questioned and examined. BMD of the lumbar spine was measured using dual x-ray absorptiometry (QDR-1000, Hologic).

Statistics: We analysed the total population as well as a random sample of 1155 women for whom additional data were collected on recalled weight at age 20-30 and on selfreported height. BMI was estimated in two ways: 1. objective BMI [= measured weight/(measured height) $\left.)^{2}\right] ; 2$. recalled BMI [= recalled body weight at age 20-30/(selfreported height) ${ }^{2}$ ]. Fractures (dependent variable) were categorized: 1. fractures sustained during the patient's lifetime; 2 . fractures after the age of $50 ; 3$. fractures that had occurred during the 5 years before BMD measurement took place. Multivariate stepwise backward and forward logistic regression analyses, using fractures as the dependent variable, were performed with all discrete and non-discrete variables (divided into quartiles). The relationship between the presence of osteoporosis and the presence of fractures was related to the changes in BMI (recalled BMI versus objective BMI).

Results: More advanced age, a positive family history of fracture and BMD were independent key predictors of fractures. Low recalled BMI was a statistically significant predictor of fractures during the patient's lifetime and of fractures after the age of 50 . Hysterectomy was associated with a higher prevalence of fractures during the patient's lifetime. Perimenopausal complaints in history seemed to be associated with a lower prevalence of fractures after the age of 50. Moderate (and heavy) occupational exercise in the past were associated with the presence of fractures after the age of 50 and fractures during the past 5 years. Sporting activities in the past showed a slight positive relationship with the presence of fractures during the patient's life time and fractures after the age of 50 . Bivariate analysis revealed that current smokers had not sustained significantly more fractures than current non-smokers, but within the subgroup of current smokers, the prevalence of fractures was significantly higher among those women who had smoked for more than 35 years. Smoking was statistically significant associated with early menopause. Early menopause was not statistically significant related to the presence of osteoporosis, but appeared to be statistically significant associated with the prevalence of fractures in the age categories over 65 years. The absolute risks of sustaining one or more fractures ranged from $3 \%$ to $44 \%$. Women in the lowest quartile of recalled and objective BMI were often osteoporotic (40\%). In this 
category, women with normal BMD had a statistically significant lower fracture risk than osteoporotic women. Women with a possibly decreased BMI were most often osteoporotic and had sustained more fractures during past 5 years than expected. Women who had (probably) always been obese were less often osteoporotic and had a much lower fracture risk.

Conclusions: Decreased as well as increasing BMI are associated with higher risk of developing fractures at older age. Prevention of fractures in obese women must be concentrated on fall prevention, whereas prevention of fractures in lean women require prevention and treatment of low BMD. 


\section{NTRODUCTION}

About $40 \%$ of Caucasian women will sustain at least one fracture during their lifetime. The lifetime fracture risk for men is about $15 \%(1,2)$. Most hip and spine fractures occur after the age of 70 , when age itself is the main risk factor for developing those fractures. Under the age of 70, a decreased bone mineral density (BMD) is a relatively stronger risk factor ${ }^{(3,4,5)}$. The determinants of low BMD implicitly determine the risk of developing osteoporotic fractures, in particular those of the hip, spine and wrist (known as 'typically osteoporotic fractures sites'). For example, body mass index (BMI), which is positively correlated with $\mathrm{BMD}$, is negatively related to fracture risk. This negative correlation corresponds well with the higher BMD but may also be related to the direct protection afforded by an increased trochanteric soft-tissue thickness ${ }^{(6,7)}$. On average, elderly women have gained $10 \mathrm{~kg}$ weight after their twenties. An interesting question is whether an increasing BMI in the course of life alters the patient's fracture risk due to a higher BMD or due to fracture protecting obesity. Opinions about obesity depend on the population which is being considered. The mean BMI of the white female population in Western Europe and the United States is about $22 \mathrm{~kg} / \mathrm{m}^{2}$ at age $20-30$ years. At age 65 the mean BMI reaches over $27 \mathrm{~kg} / \mathrm{m}^{2}(8,9)$. Thus a BMI of $27 \mathrm{~kg} / \mathrm{m}^{2}$ at age 65 is 'normal" but is obese at age 25. A lifetime body weight gain of about $5-10 \mathrm{~kg}$ is probably quite normal, a fact which must be taken into consideration when studying BMI as a risk factor for osteoporotic fractures: Present BMI and body weight are risk factors for (hip) fractures but recent studies have shown that changes in body weight or BMI may be more important ${ }^{(10,11,12)}$. However, some other studies have yielded different, sometimes controversial results ${ }^{(13)}$.

Since osteoporotic fractures present an increasing medical, psychosocial and economic burden, intervention on related risk factors is of great importance for daily practice ${ }^{\text {(14) }}$. Relevant questions are the extent to which easily obtainable BMD-related risk factors can be seen as clinically useful predictors of fracture risk; the extent to which this fracture risk can be determined without measuring BMD and the extent to which changes in these determinants during a patient's lifetime (such as weight, BMI, use of alcohol, smoking habits, etc) are clinically relevant.

Within the framework of our cross-sectional study on the prevalence of osteoporosis and related risk factors in postmenopausal women aged 50-80, data were collected on fracture history, as well as on weight and height, self-reported height, recalled weight at age 20-30 years, sporting activities at present and in the past, smoking habits at present and in the past and several other well known risk factors for osteoporosis or low BMD. Known determinants of BMD, such as age, BMI and recent fractures, which were found 
to be the key predictors of osteoporosis in our previous study, were studied for their relationship with a (recent) history of non-traumatic fracture ${ }^{(15)}$.

\section{METHODS}

\section{Population}

As has been reported previously, a cross-sectional population-based study on the prevalence of osteoporosis in daily general practice was performed between October 1992 and March 1994. 23 GPs in 12 general practice centres, all located in the south-east of The Netherlands, provided a list of all 9107 women aged $50-80$ on their register: According to the prescribed procedure, they recruited all 5303 postmenopausal women. These women, as well as every fourth (943) of the remaining group (3804) were invited to participate in our study. Of the 6246 invited subjects, 4725 postmenopausal women participated ${ }^{(15)}$. For the purpose of the present study, we analysed the total population as well as a random sample of 1155 women (study population), among whom additional data were collected on recalled weight at age 20-30 and on selfreported height took place (as previously reported ${ }^{(16)}$ ).

\section{Measurements}

Each visit started with measurements of body weight, height, BMI and BMD. The latter was measured using a computer guided DXA instrument (Hologic QDR-1000, Hologic Europe, Brussels, Belgium). With the help of the research nurse, patients then completed a questionnaire on variables possibly related to osteoporosis. In addition, all women were questioned in detail on their medical history in relation to the presence of any fractures, as reported by the patient, sustained during their lifetime.

\section{Statistics}

Statistical analysis was carried out by means of the BMDP program ${ }^{(17)}$. Data analyses were performed for the total population as well as for the study population. All calculations were done for three categories of fractures (dependent variable): fractures sustained during the patient's lifetime, fractures after the age of 50 and fractures that had occurred during the 5 years before the BMD measurement took place. BMD values were dichotomized at $0.80 \mathrm{~g} / \mathrm{cm}^{2}$ (for osteoporosis) or $0.97 \mathrm{~g} / \mathrm{cm}^{2}$ (for osteopeniatosteoporosis = low BMD). The cutoff points corresponded to 2.5 and 1 standard deviations (SD) below the mean BMD of L2-L4, measured in a healthy adult female population aged 30 , using the Hologic QDR-1000 ${ }^{(18,19)}$. For the purpose of the present study, BMI was estimated in two different ways: 1. objective BMI [ $=$ measured weight/(measured height) ${ }^{2}$; 2. recalled BMI [ recalled body weight at age $20-30 /($ self-reported height $)^{2}$. The cutoff points chosen were $27 \mathrm{~kg} / \mathrm{m}^{2}\left(\mathrm{Ql}=24, \mathrm{Q} 3=30 \mathrm{~kg} / \mathrm{m}^{2}\right)$ and $22 \mathrm{~kg} / \mathrm{m}^{2}$ 
$\left(\mathrm{Q} 1=20, \mathrm{Q} 3=25 \mathrm{~kg} / \mathrm{m}^{2 *}\right.$ ) respectively, since (in The Netherlands) the median BMI at age $60-65$ is $27 \mathrm{~kg} / \mathrm{m}^{2}$ and the median recalled BMI at age $20-30$ is $22 \mathrm{~kg} / \mathrm{m}^{2(8,20)}$.

Q3 of recalled BMI was $24: 3 \mathrm{~kg} / \mathrm{m}^{2}$, close to one of the cut-points of the inter-nationally accepted BMI

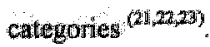

Bivariate analyses were performed on the relationship between traumatic and nontraumatic fractures and the $\mathrm{BMD}$, between the prevalences of fractures at the typical osteoporotic fracture sites and $\mathrm{BMD}$ and between the prevalences of fractures and three of the most relevant determinants, viz. $\mathrm{BMD}$, age and $\mathrm{BMI}$, and finally between these three determinants. The $2 \times 2$ tables were used to calculate odds ratios (OR) and their $95 \%$ confidenice intervals (CI). Multivariate stepwise backward and forward logistic regression analyses, using fractures as the dependent variable, were performed with all discrete and dichotomized non-discrete variables that we had used in our previous study. Where possible, these variables were divided into quartiles. The relationship between the presence of osteoporosis and the presence of fractures (three categories) was related to the changes in BMI (recalled BMI versus objective BMI), shown in $3 \times 3$ contingency tables.

\section{RESULTS}

The relevant characteristics of the study population are shown in table 1 . The characteristics are similar to those of the total population. Table 2 shows the prevalences of osteoporosis and fractures in the total population, related to age. All fractures were included, whatever their cause. The percentages of women who experienced one or more fractures during their lifetime increased with age, from $21 \%$ at age $50-54$ up to $38 \%$ at age $75-80$ and were quite similar to the increasing prevalences of osteoporosis, suggesting a relationship between developing osteoporosis and sustaining fractures. Table 2 also represents the relationship between BMI and age. The percentage of women with $\mathrm{BMI} \geq 30 \mathrm{~kg} / \mathrm{m}^{2}$ increased from $16 \%$ in the $50-54$ years category to $29 \%$ after the age of 65 .

Table 3 shows that the mean BMD in the subgroup of women with one or more traumatic fractures $(\mathrm{n}=149)$ were similar to those in the total population (see table 1). We therelore excluded traumatic fractures from further data analyses. Table 3 also shows the relationship between the prevalence of fractures at the typical osteoporotic fracture sites, and the presence of osteoporosis. We found a statistically significant difference between this relationship and that between fractures elsewhere and osteoporosis ( $\mathrm{OR}=1.4 ; \mathrm{Cl}, 1.1-1.9)$. The four most frequently mentioned 'fractures elsewhere' were those of ankle, hand, foot and arm. 
Additional bivariate analyses showed that for the 65-69 age category the use of alcohol was significantly associated with the presence of osteoporosis (OR=1.8; $\mathrm{CI}, 1.3-2.3$ ), but there was no significant relationship with the presence of fractures during the patient's lifetime This relationship was not influenced by the number of alcohol consumptions per day There appeared to be a complex relationship between smoking habits and the presence of fractures.

Current smokers did not have significantly more fractures than current non-smokers, and among current smokers the prevalences of fractures per five year age category were independent of the number of cigarettes used. However, within the subgroup of current smokers, the prevalence of fractures was significantly higher among those women who had smoked for more than 35 years (= mean number of smoking years in the study population) ( $\mathrm{OR}=1.6 ; \mathrm{CI}, 1.2-2.3)$. Furthermore, the mean BMI of the current smokers in all age categories was $1.6 \mathrm{~kg} / \mathrm{m}^{2}$ (range 1.3 to 2.0 ) lower than the mean BMI of the non-smokers. Smoking was statistically significant related to early menopause (under age $45, \mathrm{OR}=1.4 ; \mathrm{CI}, 1.2-1.7$ ). We also found a linear relationship between the age at which women had started to smoke and their year of menopause: Having started to smoke at age 10-15 corresponded to menopause at age 45 , whereas a start at age $45-50$ corresponded to a menopause at 51 years. The number of cigarettes smoked apparently influenced the onset of menopause, because in the highest quartile ( $>20 \mathrm{cig} /$ day), $40 \%$ of the women had an early menopause compared with $27 \%$ the lowest quartile ( $<10$ cig/day). Early menopause was not statistically significant related to the presence of osteoporosis but appeared to be statistically significant associated with the prevalence of fractures during patient's lifetime in the age categories over 65 years (ORs 1.5, 1.9 and 1.8 respectively). Furthermore, the prevalence of early menopause was found to be lower among elderly women.

Table 4 shows the results of the multivariate stepwise backward and forward logistic regression analyses (hereafter. regression analysis). Only variables with statistically significant ORs for fractures in one or more analyses are shown. Variables without significant ORs were the use of hormones for more than 5 years, menopause below the age of 45 , number of pregnancies, coffee intake, use of alcohol, smoking habits and current sporting activities. Table 4 shows the slightly higher ORs found in the study population (compared with the total population), which derived from the higher prevalence of fractures in this subgroup. We could not find any explanation for this higher prevalence of fractures. Recalled BMI appeared to be a statistically significant predictor of fractures during patient's lifetime and of fractures after the age of 50. More advanced age, a positive family history of fractures and the presence of osteoporosis were found to be the only systematic predictors of fractures. Hysterectomy was 
associated with a higher prevalence of fractures during the patient's lifetime. Perimenopausal complaints in the history seemed to be associated with a lower prevalence of fractures after the age of 50 . A remarkable finding was the positive relationship between moderate and heavy occupational exercise in the past and the occurrence of fractures after the age of 50 and during the past 5 years. Sporting activities in the past seemed to be associated with the presence of fractures during the patient's lifetime and fractures after the age of 50 (these fractures were not caused by the sporting activity itself).

Regression analyses with all variables not divided into quartiles, with and without BMD included, and with and without recalled BMI included revealed similar ORs for all variables except the use of alcohol and use of the pill for more than 5 years.

The use of alcohol was statistically significant related to fractures after the age of 50 and to fractures during the past 5 years (OR 1.4, CI, 1.1-1.7 and $\mathrm{OR}=1.4 ; \mathrm{CI}, 1.1-1.8$ respectively). The use of the pill for more than 5 years seemed to afford some protection against fractures after the age of $50(\mathrm{OR}=0.6, \mathrm{CI}, 0.4-0.9)$. The differences between the results of the analyses were probably due to the larger numbers. We checked for confounding by means of a separate regression analysis with the product variable 'objective $\mathrm{BMI} \times \mathrm{x}$ recalled $\mathrm{BMI}$ added into the models, which yielded similar results. Finally, all analyses were repeated with the variable BMD cut off at 0.970 $\mathrm{gr} / \mathrm{cm}^{2}$ (osteopenia + osteoporosis) instead of $0.800 \mathrm{gr} / \mathrm{cm}^{2}$. No additional conclusions could be drawn from these analyses (results not shown).

Tables $5 \mathrm{a}$ and $5 \mathrm{~b}$ represent the relationships between recalled BMI and objective BMI using Q1 and Q3 at the age of 25 years ( $5 \mathrm{a})$ and 65 years $(5 \mathrm{~b})$ respectively. Table $5 \mathrm{c}$ is a combination of $5 \mathrm{a}$ and $5 \mathrm{~b}$ : recalled BMI at age 25 with the corresponding cutoff points compared with objective BMI at age 65 with their corresponding cutoff points. Table $5 \mathrm{c}$ was used to construct table 6 , which shows the relationships between the presence of osteoporosis and the presence of fractures during the patient's lifetime (6a), fractures after the age of $50(6 \mathrm{~b})$ and fractures during the past 5 years $(6 \mathrm{c})$, in relation to the changes in BMI between the ages of 20-30 (recalled BMI) and the present BMI (objective BMI). Women in the lowest quartiles of recalled and objective BMI were often osteoporotic (40\%). In this category, women with normal BMD had a statistically significant lower fracture risk than osteoporotic women. The absolute risk, not related to the presence of osteoporosis, of having one or more fractures during the past 5 years ranged from $3 \%$ to $28 \%$ (table $6 \mathrm{c}$ ), that of having one or more fractures after the age of 50 from $4 \%$ to $28 \%$ (table $6 \mathrm{~b}$ ) and that of having one or more 'fractures during the patient's lifetime from $15 \%$ to $44 \%$ (table $6 \mathrm{a}$ ). Women with a possibly decreased BMI (recalled $\mathrm{BMI} \geq 25$ and objective $\mathrm{BMI} \leq 24$ ) were most often osteoporotic and had 
sustained more fractures during the past 5 years than expected $(\mathrm{OR}=4.0, \mathrm{CI}, 1.4-11.4)$. Women who had probably always been obese (recalled $\mathrm{BM} \geq 25$ and objective $B M I \geq 30$ ) were less often osteoporotic but, more importantly, seemed to have a much lower fracture risk (ORs $0.6,0.2$ and 0.3 respectively). Table 6 clearly shows that the $\mathrm{BMI}$ at age 20-30 years predicts the BMI at older age, as has been reported earlier ${ }^{(16)}$.

\section{DISCUSSION}

Age, a positive family history of fractures and BMD were found to be the most important predictors of fractures during the patient's lifetime, 'fractures after the age of 50 and fractures during the past 5 years. Other determinants were relevant only in one or two fracture categories. Comparing the results with those from our previous study, the determinants investigated were relatively more important in predicting osteoporosis than fractures. However, we found no fundamental differences: all factors had low ORs for osteoporosis as well as for one or more fracture categories. The finding that the determinants of fractures were BMD-independent is more important. In the very elderly women in particular, BMD was found to be a minor risk factor for fractures. Hence, BMD measurement is not always necessary to assess fracture risk in very elderly women. While BMI was earlier found to be one of the key predictors of osteoporosis, it appeared to be of less or no importance in predicting fractures. In contrast, recalled BMI predicted the development of fractures as well as osteoporosis. A positive family history of fracture was of less importance in predicting osteoporosis, but was one of the key predictors of fractures, suggesting that other hereditary bone qualities, such as bone volume, structure and shape, may play a more significant role in the risk of fractures.

Our regression analyses did not reveal significant figures for risks resulting from early menopause. However, over the age of 65 , these women seemed to have significantly more fractures. The explanation for this phenomenon could be a relatively high bone turnover in women over 65 with early menopause: Such as early menopause, smoking was not found to be a risk factor for fractures. But the significant relationship between smoking and the presence of early menopause suggests that smoking is an effect modifier for early menopause and fractures after age 65. The use of alcohol, but not the number of alcohol consumptions per day or per week, appeared to be a significant predictor of fractures during the past 5 years. Apparently, this factor is more important at more advanced age, partly because the number of these fractures increases with age. From a physiological point of view, sporting activities in the past were expected to be associated with relatively fewer fractures (and better BMD), but our study did not confirm this. Sports in the past was in fact a small but significant predictor of fractures during the patient's lifetime and fractures after the age of 50 , possible because sporting activities are 
associated with lower BMI and, as a result, with relatively little protection by soft tissues. In general, fractures and BMI might also be related to genetic constitution and body shape. A similar relationship could be relevant with respect to occupational exercise. However, the situation in this respect is more complicated, because an active lifestyle often goes together with a sporting lifestyle.

Table $5 \mathrm{c}$ was used to derive table 6 . We had two arguments to use table $5 \mathrm{c}$ instead of $5 \mathrm{a}$ or $5 \mathrm{~b}$. Firstly, the differences between the 'normal' values at age 20-30 and the 'normal' values at present correspond best with the changes in BMI during the patient's lifetime. Secondly, table 5e shows the far best distribution of the numbers. Table 6 shows the effect of time on the development of fractures in relation to BMD and BMI. Despite the small numbers it can be concluded that women who were obese at age 20-30 and were 'normal' at older age had the lowest risk of developing fractures during their lifetime. In contrast, decreased as well as increasing BMI is associated with a higher risk of having sustained fractures during the past 5 years. This is in accordance with the previous finding that both weight loss and excess weight gain, in addition to BMI, are strong predictors of hip fractures ${ }^{(11,12)}$. Women with low recalled BMI and low or moderate objective BMI are at high risk of sustaining fractures. In this category the presence of osteoporosis was of overriding importance. Women with high recalled BMI and high objective BMI had the lowest risk for each fracture category. In this category of women, the presence of osteoporosis was less important. These results indicate that prevention of fractures in obese women must be concentrated on preventing falls, whereas the prevention of fractures in lean women requires prevention or treatment of low $\mathrm{BMD}^{(24)}$.

The present study describes etiological aspects of bone quality and fracture risk. In general, a longitudinal design is needed to study etiology. Our study comes close to this requisite by including variables with a longitudinal character. Furthermore, this longitudinal aspect could be studied explicitly for BMI. Verifying our results, however, would require a prospective longitudinal study including our significant variables. The external validity of our study was critically reviewed in our previous investigations ${ }^{(15,16)}$. Briefly, we found no reasons to suspect selection bias in the present study. 
Table 1. Characteristics of the study population ( $\mathrm{n}=1155)$ compared with the total population $(\mathrm{N}=4203)$.

\begin{tabular}{|c|c|c|c|c|c|}
\hline & $\begin{array}{l}\text { study } \\
\text { population } \\
m=1155\end{array}$ & & & $\begin{array}{l}\text { total popullation } \\
\mathrm{N}=4203\end{array}$ & \\
\hline Vaniable & mean (SD) & median & $(\mathrm{Q1-Q3)}$ & mean (SD) & $\operatorname{median}(\mathrm{Ql}-\mathrm{Q3})$ \\
\hline $\mathrm{BMD}\left(\mathrm{gr} / \mathrm{cm}^{2}\right)$ & $0.921(0.166)$ & 0.912 & $(0.802-1.017)$ & $0.925(0.163)$ & $0.913(0.818-1.038)$ \\
\hline Age (years) & $63(7)$ & 62 & $(57-68)$ & $(7)$ & $62(57-68)$ \\
\hline Weight (kg) & $71 \quad(13)$ & 70 & $(62-78)$ & (12) & $70 \quad(63-78)$ \\
\hline Height $(\mathrm{cm})$ & $162(6)$ & 162 & $(157-165)$ & 161 & $161(157-165)$ \\
\hline Self-reported height $(\mathrm{cm})$ & $164 .(6)$ & 165 & $(160-168)$ & & \\
\hline Recalled weight (kg) & $60 \quad(10)$ & 60 & $(53-65)$ & & \\
\hline Objective BMI $\left(\mathrm{kg} / \mathrm{m}^{2}\right)$ & 27 (5) & 27 & $(24-29)$ & ( 5$)$ & $27(24-30)$ \\
\hline Recalled BMT $\left(\mathrm{kg} / \mathrm{m}^{2}\right)$ & 22 (4) & 22 & $(20-24)$ & & \\
\hline
\end{tabular}

Tabte 2. Prevalences (in numbers and percentages) of osteoporosis, fractures and BMI categories in the total population, related to age:

\begin{tabular}{|c|c|c|c|c|c|c|c|}
\hline Age & $50-54$ & $55-59$ & $60-64$ & $65-69$ & $70-74$ & $75-80$ & all patients \\
\hline $\begin{array}{l}\text { Numbers of } \\
\text { patients }\end{array}$ & 689 & 976 & 975 & 761 & 546 & 256 & $\mathrm{n}=4203$ \\
\hline $\begin{array}{l}\text { Prevalences of } \\
\text { asteoporosis }\end{array}$ & $10 \%$ & $\begin{array}{r}18 \% \\
\\
\end{array}$ & $26 \%$ & $29 \%$ & $30 \%$ & $38 \%$ & $23 \%$ \\
\hline \multicolumn{8}{|l|}{$\begin{array}{l}\text { Prevalences of } \\
\text { fractures }\end{array}$} \\
\hline during lifetime & $147,21 \%$ & $234,24 \%$ & $240,25 \%$ & $228,30 \%$ & $168,31 \%$ & $97,38 \%$ & $1114,26 \%$ \\
\hline after age 50 & $14,2 \%$ & $86, \quad 9 \%$ & $126,13 \%$ & $146,19 \%$ & $136,25 \%$ & $74,29 \%$ & $582,14 \%$ \\
\hline $\begin{array}{l}\text { during past } 5 \\
\text { years }\end{array}$ & $38,6 \%$ & $67,7 \%$ & $74,8 \%$ & $72,10 \%$ & $63,82 \%$ & $35,14 \%$ & $349,8 \%$ \\
\hline \multicolumn{8}{|l|}{$\begin{array}{l}\text { Prewalences of } \\
B M I\end{array}$} \\
\hline$\leq 24 \mathrm{~kg} / \mathrm{m}^{2}(\mathrm{Q} 1)$ & $35 \%$ & $270 \%$ & $23 \%$ & $19 \%$ & $18 \%$ & $23 \%$ & 1034 \\
\hline $24-30 \mathrm{~kg} / \mathrm{m}^{2}$ & $49 \%$ & $49 \%$ & $53 \%$ & $52 \%$ & $53 \%$ & $40 \%$ & 2134 \\
\hline$\geq 30 \mathrm{~kg} / \mathrm{m}^{2}(03)$ & $16 \%$ & $24 \%$ & $24 \%$ & $29 \%$ & $29 \%$ & $28 \%$ & 1035 \\
\hline
\end{tabular}

Table 3. Relationship between causes and locations of fractures and BMD $\left(\mathrm{gr}_{\mathrm{cm}} \mathrm{cm}^{2}\right)$ in the total population $(\mathrm{N}=4203)$.

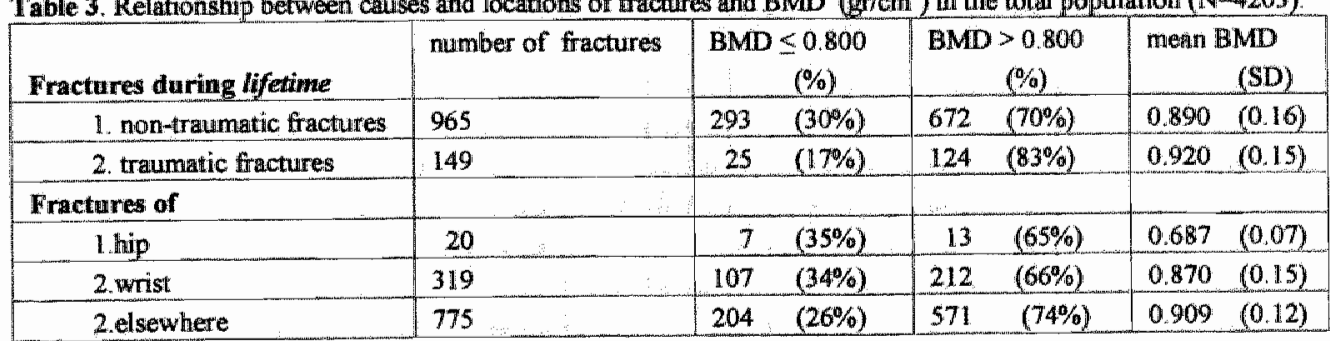




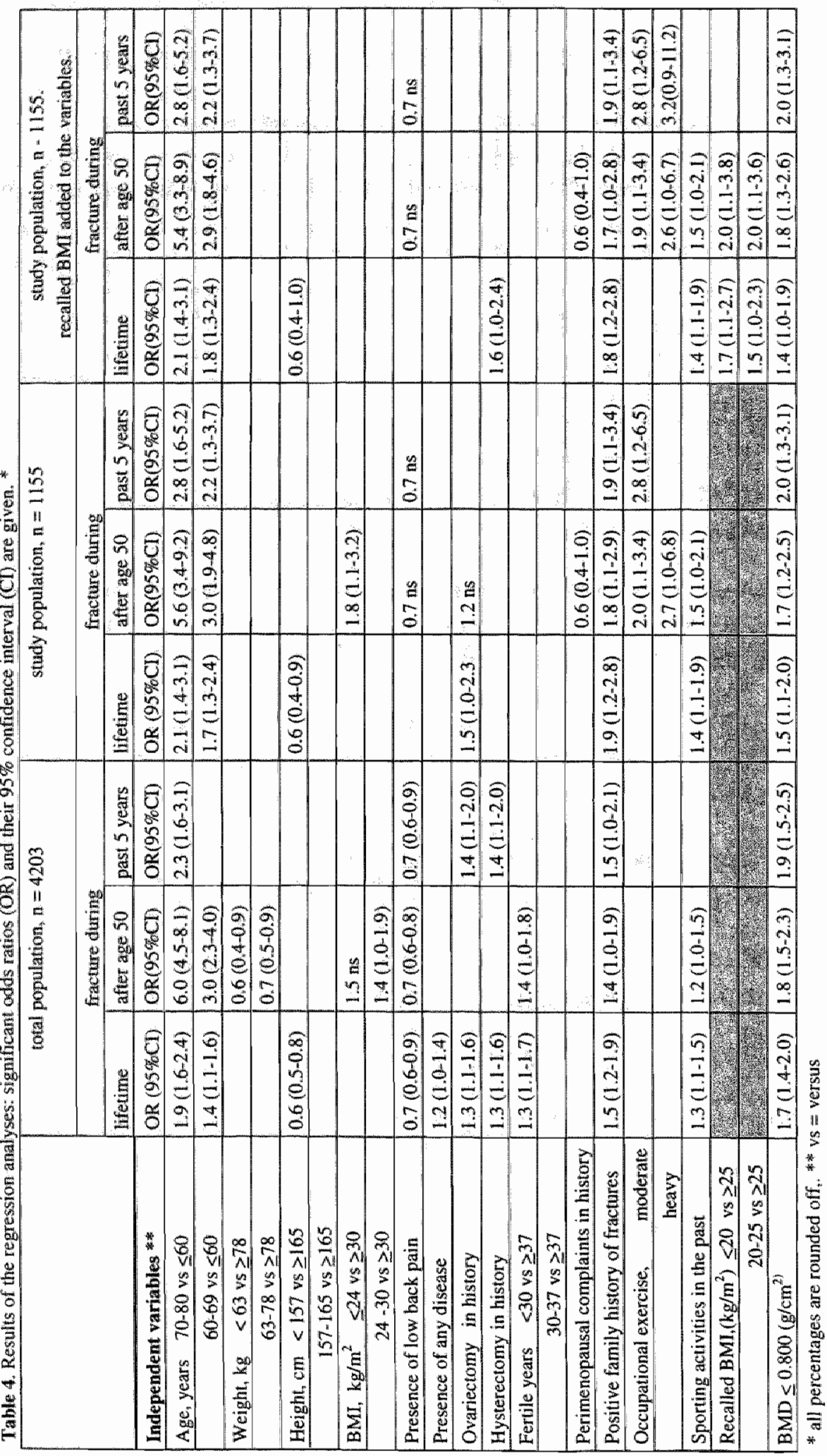


Table Sa. Relationship between recalled BMI $\left(\mathrm{kg} / \mathrm{m}^{2}\right)$ and objective BMI $\left(\mathrm{kg} / \mathrm{m}^{2}\right)$, in the study population ( $\mathrm{n}=155$ ), showing numbers of persons

\begin{tabular}{|c|c|c|c|c|}
\hline & \multicolumn{3}{|c|}{ Objective BMT } & total \\
\hline & $\leq 20$ & $20-25$ & 225 & \\
\hline Recalled BMI $\leq 20$ & 24 & 127 & 163 & 314 \\
\hline $20-25$ & 11 & 211 & 430 & 652 \\
\hline$\geq 25$ & 2 & 24 & 163 & 189 \\
\hline & 37 & 362 & 756 & 1155 \\
\hline
\end{tabular}

Table Sb. Relationship between recalled BMI $\left(\mathrm{kg} / \mathrm{m}^{2}\right)$ and objective BMI $\left(\mathrm{kg} / \mathrm{m}^{2}\right)$, in the study population ( $n=1155$ ), showing mumbers of persons.

\begin{tabular}{|c|r|c|r|r|}
\hline & \multicolumn{3}{|c|}{ Objective BMT } & total \\
\hline & $\leq 24$ & $24-30$ & $\geq 30$ & \\
\hline Recalled BMI $\leq 24$ & 254 & 487 & 131 & 872 \\
\hline $24-30$ & 30 & 118 & 95 & 243 \\
\hline$\geq 30$ & 1 & 9 & 30 & 40 \\
\hline & 285 & 614 & 256 & 1155 \\
\hline
\end{tabular}

Table $5 \mathrm{c}$. Relationship between recalled BMI $\left(\mathrm{kg} / \mathrm{m}^{2}\right)$ and objective BMI $\left(\mathrm{kg} / \mathrm{m}^{2}\right)$, in the study population ( $n=1155$ ), showing numbers of persons.

\begin{tabular}{|c|c|c|c|c|}
\hline & \multicolumn{3}{|c|}{ Objective BMI } & total \\
\hline & $\leq 24$ & $24-30$ & $\geq 30$ & \\
\hline Recalled BMI $\leq 20$ & 121 & 150 & 43 & 314 \\
\hline $20-25$ & 146 & 384 & 122 & 652 \\
\hline$\geq 25$ & 18 & 80 & 91 & 189 \\
\hline & 285 & 614 & 256 & 1155 \\
\hline
\end{tabular}


Table 6a. Relationship between the presence of osteoporosis and the presence of fractures 'during lifetime, related to the differences berween BMI at age 20-30 years (recalled BMI) and present BMI (objective BMI). Significant odds ratio s (OR) are shown on the bottom of the table.

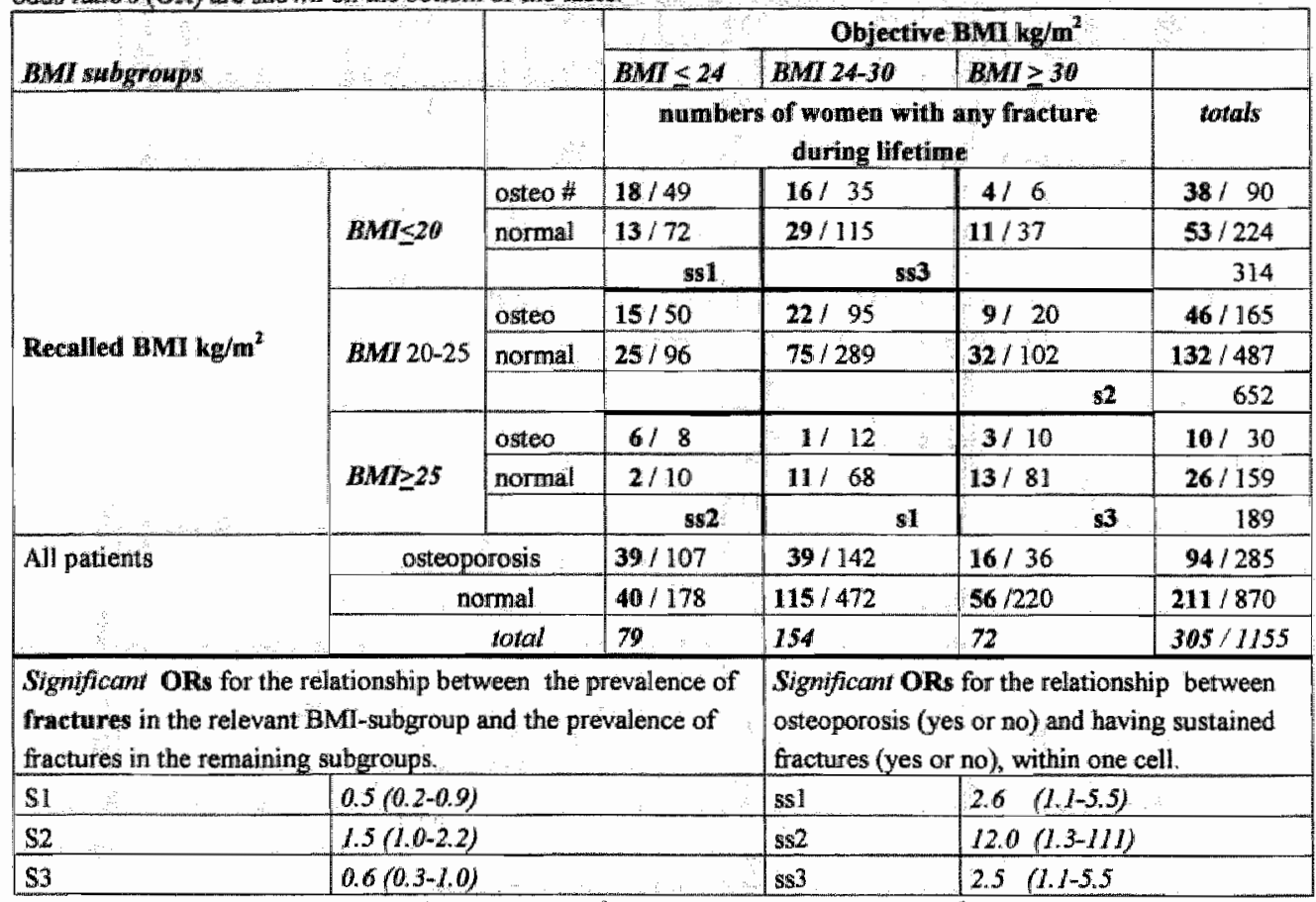

\# osteo = BMD lumbar spine (L2-L4) $\leq 0.800 \mathrm{gr} / \mathrm{cm}^{2}$, normal $=\mathrm{BMD}>0.800 \mathrm{gr} / \mathrm{cm}^{2}$ 
Table 6b. Relationship between the presence of osteoporosis and the presence of fractures sustained after age 50 ", related to the differences between BMI at age 20-30 years (recalled BMI) and present BMI (objective BMn): Significant odds ratio's (OR) are shown at the bottom of the table.

\begin{tabular}{|c|c|c|c|c|c|c|}
\hline \multirow{2}{*}{\multicolumn{2}{|c|}{ BMA subgroups }} & \multirow{3}{*}{ 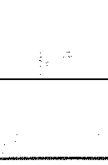 } & \multicolumn{4}{|c|}{ Objective BMI $\mathrm{kg} / \mathrm{mi}^{2}$} \\
\hline & & & $B M I \leq 24$ & BMA $24-30$ & $B M=30$ & \\
\hline & & & \multicolumn{3}{|c|}{$\begin{array}{c}\text { numbers of women with any fracture } \\
\text { after age } 50\end{array}$} & totals \\
\hline \multirow{9}{*}{ Recalled BMI kg/m $\mathbf{m}^{2}$} & \multirow{3}{*}{$B M T \leq 20$} & osteo \# & $13 / 49$ & $11 / 35$ & 216 & 26190 \\
\hline & & normal & $4 / 72$ & $14 / 115$ & $5 / 37$ & 231224 \\
\hline & & $\leq$ & ss4 & ss 5 & & 314 \\
\hline & \multirow{3}{*}{ BMI $20-25$} & osteo. & $12 / 50$ & $16 / 95$ & 7120 & $35 / 165$ \\
\hline & & normal & $14 / 96$ & $49 / 289$ & $13 / 102$ & $76 / 487$ \\
\hline & & & & & $8 s 6$ & 652 \\
\hline & \multirow{3}{*}{$B M \geq 25$} & osteo & $4 / 8$ & $1 / 12$ & $3 / 10$ & $8 / 30$ \\
\hline & & normal & $1 / 10$ & 8168 & $1 / 81$ & $10 / 159$ \\
\hline & & & & & 84,587 & 189 \\
\hline \multirow[t]{3}{*}{ All patients } & \multicolumn{2}{|c|}{ osteoporosis } & $29 / 107$ & $28 / 142$ & $12 / 36$ & $69 / 285$ \\
\hline & \multicolumn{2}{|c|}{ normal } & $19 / 178$ & $71 / 472$ & $19 / 220$ & $109 / 870$ \\
\hline & \multicolumn{2}{|c|}{ total } & 48 & 99 & 31 & $178 / 1155$ \\
\hline \multicolumn{3}{|c|}{$\begin{array}{l}\text { Significant ORs for the relationship between the } \\
\text { prevalence of fractures in the relewant BMI-sub- } \\
\text { group and the prevallence of fractures in the } \\
\text { remaining subgroups. }\end{array}$} & \multicolumn{4}{|c|}{$\begin{array}{l}\text { Significani ORs for the relationship between osteoporosis } \\
\text { (yes or no) and having sustained fractures (yes or no), within } \\
\text { one cell. }\end{array}$} \\
\hline \multirow[t]{4}{*}{84} & \multicolumn{2}{|l|}{$0.2(0.1-0.4)$} & $s 54$ & \multicolumn{3}{|c|}{ 6.I $(1.9-20.2)$} \\
\hline & \multicolumn{2}{|c|}{$\therefore \quad$} & $s s 5$ & \multicolumn{3}{|l|}{$3.3(1.3-8.2)$} \\
\hline & \multicolumn{2}{|c|}{ \& } & sso $\cdots$ & \multicolumn{3}{|c|}{$3.7(1.1-109)$} \\
\hline & & & ss.7 & $34.0(3.1-37$ & & \\
\hline
\end{tabular}

\# osteo = BMD lumbar spine $(\mathrm{L} 2-\mathrm{L} 4) \leq 0.800 \mathrm{gr} / \mathrm{cm}^{2}$, normal $=\mathrm{BMD}>0.800 \mathrm{gr} / \mathrm{cm}^{2}$ 
Table 6e. Rellationship between the presence of osteoporosis and the presence of fractures sustained during past 5 years, related to the differences between BMI at age 20-30 years (recalled BMI) and present BMI (objective BMT) Significant odds ratio (OR) are shown at the bottom of the table

\begin{tabular}{|c|c|c|c|c|c|c|}
\hline \multirow{2}{*}{\multicolumn{2}{|c|}{ BMI swbgroups }} & \multirow{2}{*}{ 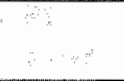 } & \multicolumn{4}{|c|}{ Objective BMI $\mathrm{kg} / \mathrm{m}^{2}$} \\
\hline & & & $B M I \leq 24$ & $B M I 24-3$ & $B M I \geq 30$ & \\
\hline & & : & \multicolumn{3}{|c|}{$\begin{array}{l}\text { numbers of women with any fracture } \\
\text { during past } 5 \text { years }\end{array}$} & totals \\
\hline \multirow[t]{3}{*}{ : } & \multirow[t]{3}{*}{$B M I 20$} & osteo \# & $9 / 49$ & 5135 & $2 / 6$ & $16 / 90$ \\
\hline & & mormall & $1 / 72$ & $5 / 115$ & $2 / 37$ & $8 / 224$ \\
\hline & & & 888 & & & $3 / 4$ \\
\hline \multirow{6}{*}{ Recalled BMI $\mathrm{kg} / \mathrm{m}^{2}$} & \multirow[t]{3}{*}{$B M L 20-25$} & osteo & $8 / 50$ & $8 / 95$ & $4 / 20$ & $20 / 165$ \\
\hline & & normal & $8 / 96$ & $30 / 289$ & 81102 & $46 / 487$ \\
\hline & & & & & & 652 \\
\hline & \multirow[t]{3}{*}{$B M \geq 25$} & osteo & $4 / 8$ & 0112 & 2110 & $6 / 30$ \\
\hline & & normal & $1 / 10$ & $7 / 68$ & $1 / 81$ & $9 / 159$ \\
\hline & & & 85 & & $\mathrm{s6}, \mathrm{ss9}$ & 189 \\
\hline \multirow[t]{3}{*}{ All patients } & \multicolumn{2}{|c|}{ osteoporosis } & $21 / 107$ & $13 / 142$ & $8 / 36$ & $42 / 285$ \\
\hline & \multicolumn{2}{|c|}{ normal } & $10 / 178$ & $42 / 472$ & $11 / 220$ & $63 / 870$ \\
\hline & \multicolumn{2}{|r|}{ rotal } & 31 & 55 & 19 & 1155 \\
\hline \multicolumn{3}{|c|}{$\begin{array}{l}\text { Significant ORs for the relationship between } \\
\text { the prevalence of fractures in the relevant BMI- } \\
\text { subgroup and the prevalence of fractures in the } \\
\text { remaining subgroups. }\end{array}$} & \multicolumn{4}{|c|}{$\begin{array}{l}\text { Sigmificant ORs for the relationship between osteoporosis } \\
\text { (yes or no) and having sustained fractures (yes or no), within } \\
\text { one cell. }\end{array}$} \\
\hline 85 & \multicolumn{2}{|c|}{$4.0(1.4-11.4)$} & 5538 & \multicolumn{3}{|c|}{$16.0(2.0-130)$} \\
\hline 56 & \multicolumn{2}{|c|}{$0.3(0.1-1.0)$} & $\operatorname{sis} 9$ & \multicolumn{3}{|c|}{$20.0(1.6-245)$} \\
\hline
\end{tabular}

\# osteo $=$ BMD lumbar spine $(\mathrm{L} 2-\mathrm{L} 4) \leq 0.800 \mathrm{gr} / \mathrm{cm}^{2}{ }^{2}$ normal $=\mathrm{BMD}>0.800 \mathrm{gr} / \mathrm{cm}^{2}$ 


\section{References}

1. Cummings SR, Nevitt MC, Browner WS, Stone K, Fox KM, Ensnud KE, et al. Risk factors for hip fracture in white women. N Engl J Med 1995;332:767-73

2. Kannus $P$, Parkkari I, Sievằnen, Heinonen $A$, Vuơi $\mathrm{L}$, Järvinen $\mathrm{M}$. Epidemiology of hị fractures. Bone $1996 ; 18: 57 \mathrm{~s}-63 \mathrm{~s}$

3. Anonymous. Assessment of fracture risk and its application to screening for postmenopausal osteoporosis. Geneva: WHO Technical report series 843, 1994

4. De Laet $\mathrm{CEDH}$, Hout BA van, Burger $\mathrm{H}$, Hofman A, Pols HAP. Bone density and risk of hip fracture in men and women: cross sectional analysis. BMJ 1997;315:221-5

5. Ott SM. When bone mass fails to predict bone failure. Calcif Tissue Int $1003 ; 53$ (suppl) s7 -s13

6. Greenspan SL, Myers ER, Maitland LA, Resnick NM, Hayes WC. Fall severity and bone mineral density as risk factors for hip fracture in ambulatory elderly. JAMA 1994;271:128-133

7. Lauritzen JB. Hip fractures: incidence, risk factors, energy absorption, and prevention. Bone $1996 ; 18: 65 \mathrm{~s}-75 \mathrm{~s}$

8. Flegal KM, Carroll MD, Kuczmarski RJ, Johnson CL. Overweight and obesity in the United States: prevalence and trends, 1960-1994. Int J Obes 1998;22:39-47

9. Statistisch Jaarboek 1995. s'Gravenhage: Centraal bureau voor de statistiek, 1995

10. Cummungs SR, Newitt MC, Browner WS, Stone H, Fox K, Ensrud KE, et al. Risk factors for hip fracture in white women. N Engl J Med 1995;332,767-73

11. Meyer HA, Tverdal A, Falch JA. Changes in body weight and incidence of hip fracture among middle aged Norwegians, BMI 1995;311:91-2

12. Meyer HA, Tverdal A, Falch JA. Risk factors for hip fractures in middle aged Norwegian women and men. Am J Epidemiol 1993;137:1202-11

13. Ensrud KE, Cauley J, Lipschutz $R$, Cummings SR. Weight change and fractures in older women. Study of Osteoporotic Fractures Study Group. Arch Intern Med 1997;157:857-63

14. Law MR, Wald NJ, Meade TW. Strategies for prevention of osteoporosis and hip fractures. BMJ $1991 ; 303: 453-9$

15. Van der Voort DJM, Dinant GJ, Rinkens PELM, Van der Voort-Duindam CJM, Van Wersch JWJ, Geusens PP. Diagnostic accuracy of an algorithm for quick detection of patients with low bone mineral density in everyday general practice. Accepted for J Clin Epidemiol.

16. Van der Voort DJM, Brandon S, Dinant GJ, Van Werseh JWJ. Screening for osteoporosis using easily obtainable biometrical data: diagnostic accuracy of measured, self-reported and recalled BMI, and related costs of bone mineral density measurements. Osteoporos Int 2000;11:233-9

17. Dixon WJ, Brown MB, Engelman L, Holl MA, Jenrich RI. BMDP statistical software manual. Berkeley: University of California Press, 1990

18. Bone Density Reference Data. Bruxelles: S.A. Hologic Europe.

19. Steiger P, Cummings SR, Black DM, Spencer NE, Genant HK. Age-related decrements in bone mineral density in women over 65. J Bone Miner Res 1992;7:625-32

20. Age and antropometric variables among dutch elderly men and women. Zeist: Institute CIVOToxicologie, 1988 
21. Garrow IS. Indices of adipositas: Nutr Abst Rev 1983;53:697-708

22. Bray GA. Classification and evaluation of the obesities. Med Clin N Am 1989;73:161-84

23. Anonymous WHO study group on diet nutrition and prevention of noncommunicable diseases. Geneva:WHO Technical report series 797, 1990

24. Stalenhoef PA. Falls in the elderly. A primary care based study (thesis). Maastrieht Universiteit Maastricht, 1999

\subsection{Samenvatting}

Doel van de studie. In hoeverre voorspellen makkelijk verkrijgbare factoren die gerelateerd zijn aan de bot mineraal dichtheid (BMD) het ontstaan van fracturen. In hoeverre zijn veranderingen van deze voorspellende factoren tijdens het leven relevant voor het ontstaan van fracturen.

Studie design. Het betrof een cross-sectionele studie.

Patienten en methoden. De studiepopulatie bestond uit 4725 postmenopauzale vrouwen van 50-80 jaar die ingeschreven stonden bij 23 huisartsen. De vrouwen werden onderzocht en ondervraagd. Met behulp van dual x-ray absorptiometry (QDR-1000, Hologic) werd de BMD van de lumbale wervelkolom gemeten.

Statistiek. Zowel de totale populatie als een steekproefpopulatie van 1155 vrouwen, werden geanalyseerd. Er werden data verzameld over het gewicht van de patiente toen ze tussen de 20 en 30 jaar was en over haar subjectieve lengte. De BMI werd op twee manieren berekend: 1 . objectieve BMI [=gemeten lichaamsgewicht/(gemeten lengte) ${ }^{2}$ ]; 2. vroegere BMI [=het door de patiënte geschatte lichaamsgewicht op 20-30 jarige leeftijd/(de door de patiënte geschatte vroegere lengte) ${ }^{2}$ ]. Fracturen (de afhankelijke variabele) werden onderverdeeld in: 1 . fracturen tijdens het leven; 2 . fracturen na het vijftigste levensjaar, 3 . fracturen die tijdens de laatste 5 jaar voor de BMD meting waren opgetreden. Multivariate stepwise backward and forward logistic regressie analyses, waarin de drie fractuur-categorièn als afhankelijke variabele werden gebruikt, werden uitgevoerd met alle discrete en niet-discrete variabelen (verdeeld in kwartielen). De relatie tussen het hebben van osteoporose en de aanwezigheid van fracturen werd gerelateerd aan de veranderingen in BMI (objectieve BMI versus vroegere BMI).

Resultaten:

Hoge leeftijd, fracturen in de familie geschiedenis, en de BMD waren de sterkste voorspellers voor fracturen. BMI was een statistisch significante voorspeller van 'fracturen tijdens het leven' en van 'fracturen na het vijttigste levensjaar'. Hysterectomie was geassocieerd met het vaker voorkomen van 'fracturen tijdens het leven'. Perimenopauzale klachten in het verleden bleken geassocieerd te zijn met het minder voorkomen van "fracturen na het vijftigste levensjaar". Gemiddelde (en zware) werkbelasting in het verleden was positief geassocieerd met de aanwezigheid van fracturen na het vijftigste levensjaar en met 'fracturen tijdens de laatste 5 jaar' $(\mathrm{OR}=1,9$; 
CI, 1,1-3,4 en $\mathrm{OR}=2,8 ; \mathrm{CI}, 1,2-6,5$ respectievelijk). Sportieve activiteiten in het verleden hadden een licht positieve associatie met de aanwezigheid van fracturen 'tijdens het leven' en 'na het vijftigste levensjaar'. Bivariabele analyses toonden aan dat vrouwen die roken niet significant meer fracturen hadden dan vrouwen die niet roken. Binnen de subgroep 'rooksters' bleek echter dat er significant meer fracturen voorkwamen bij de vrouwen die meer dan 35 jaar gerookt hadden. Roken was statistisch significant geassocieerd met vroege menopauze ( $\mathrm{OR}=1,4 \mathrm{Cl}, 1,2-1,7)$. Vroege menopauze was niet statistisch significant gerelateerd met de aanwezigheid van osteoporose, maar bleek statistisch significant gerelateerd te zijn met de aanwezigheid van fracturen in de leeftijdscategorièn boven de 65 jaar (OR's $1,5,1,9$ en 1,8 respectievelijk).

De absolute risico's voor het hebben van een of meer 'fracturen tijdens de afgelopen 5 jaar' varieerden van $3 \%$ tot $28 \%$, voor een of meer 'fracturen na het vijftigste levensjaar' van $4 \%$ tot $28 \%$ en voor een of meer 'fracturen tijdens het leven' van $15 \%$ tot $44 \%$. Vrouwen in het laagste kwartiel van de vroegere BMI en objectieve BMI zijn vaak osteoporotisch (40\%). In deze categorie hadden vrouwen met een normale BMD statistisch significant minder fracturen dan de categorie 'osteoporotische' vrouwen. Vrouwen waarvan de BMI tijdens het leven lager werd zijn vaker osteoporotisch en vertonen meer 'fracturen tijdens de laatste 5 jaar' dan verwacht ( $\mathrm{OR}=4,0 ; \mathrm{CI}, 1,4-11,4)$. Vrouwen die (zeer waarschijnlijk) altijd relatief te dik zijn geweest waren minder osteoporotisch en hadden een veel lager risico op fracturen.

Conclusies: Zowel een verlaagde alls een verhoogde BMI is geassocieerd met een verhoogde kans op het ontwikkelen van fracturen op latere leeftijd. De fractuurpreventie bij te dikke vrouwen moet gericht worden op de valfrequentie, terwijl de fractuurpreventie bij slanke vrouwen de preventie en behandeling van een lage BMD vereist. 
Hoofdstuk 7 


\section{Hoofdstuk 7}

Aging and social and socio-economic determinants of osteoporosis, studied in healthy postmenopausal women

Authors

1. D.J.M. van der Voort, MD (1), general practitioner

2. D. van der Voort, MSc (2), PhD-student

3. P.P. Geusens, MD, PhD, professor of Rheumatology (3)

4. G.J. Dinant, $\mathrm{MD}, \mathrm{PhD}$, professor of Clinical Research in General Practice (1)

(1): University Maastricht, Department of General Practice and Research Institute for Extramural and Transmural Health Care, Maastricht, The Netherlands

(2): University of Groningen, Department of Biological Psychiatry, Groningen, The Netherlands

(3): Department of Internal Medicine, University Hospital, Maastricht, The Netherlands

Submitted 


\section{Abstract}

Objective: The aim of the present study was to establish to what extent osteoporosis related social and socio-economic factors are able to predict the presence of osteoporosis and to what extent they can be used in osteoporosis prevention strategies in primary health care.

Design: Cross-sectional population-based study.

Subjects and measurements: 2078 healthy postmenopausal Caucasian women aged 5080 , registered with 23 general practitioners (GPs), were examined (weight, height, body mass index and BMD of the lumbar spine (DEXA)) and questioned on variables possibly related to osteoporosis, including sporting activities, present and past occupation, level of education, number of children and calcium intake ('social and socio-economic factors').

Statistics: Bivariate analyses were performed on the relationship between the social and socio-economic factors and BMD, in relation to age. BMD of the lumbar spine (L2-L4) was cut off at $0.800 \mathrm{~g} / \mathrm{cm}^{2}$ for osteoporosis and at $0.970 \mathrm{~g} / \mathrm{cm}^{2}$ for low BMD. Multivariate stepwise backward and forward logistic regression analyses (hereafter regression analysis) were performed with the above social and socio-economic variables, as well as all osteoporosis related variables that we had used in a previous study.

Results: In the over 65 age categories, healthy women were statistically significant more often osteoporotic and had a lower weight than diseased women $(\mathrm{OR}=1.8 ; \mathrm{CI}, 1.4-2.2$ for osteoporosis and $\mathrm{OR}=1.5 ; \mathrm{Cl}, 1.2-1.8$ for weight below $70 \mathrm{~kg}$ ). No consistent influence of social or socio-economic factors on BMD was found. Apart from the previously found statistically significant determinants of BMD, only low calcium intake, heavy occupational exercise in the past and sporting activities 'with axial pressure' in the past, were found to be statistically significantly related to BMD. However, this was only found in the category of women below the age of 65 . In all age categories, weight explained the different prevalences of osteoporosis in the categories of healthy and diseased women.

Conclusions: Age, being the most consistent determinant of BMD, suggests that osteoporosis is a typically degenerative condition. The association between age and BMD is more evident in healthy than in diseased women. Weight modifies the effect of age on $B M D$, illustrating that osteoporosis certainly is an active process. Regarding osteoporosis prevention strategies in primary health care, the use of social and socio-economic factors in the management of osteoporosis would not be very helpful. In contrast with the findings of our previous study (performed in an unselected population), the present study (performed in healthy subjects) showed a linear age-related decrease in BMD. Many other studies have found the similar relationship. On the basis of our findings, we conclude that these studies were performed with rather healthy patients with a relatively low weight (and a relatively small number of patients over 65). 


\section{INTRODUCTION}

Aging is associated with a number of chronic diseases, such as those of the cardiovascular and locomotor tracts. Early stages of many of these diseases cannot easily be detected due to a lack of symptoms. Osteoporosis is a good example of this problem. The presence of osteoporosis is often recognised just after these patients have sustained a fracture after a minor trauma. At the same time, in daily practice physicians tend to forget that there are reasons to suspect that non-medical, yet easily assessable social and socioeconomic factors influence the early development of low bone mineral density (BMD). An interesting question is to what extent the complex of social and socio-economic factors, as a part of the daily life, modifies the effect of advancing age on the development of low BMD and how this might help detect the condition.

Relevant social and socio-economic factors for osteoporosis, include sporting activities, occupational exercise, level of education, number of children and dietary pattern. Sporting activities during youth may be able to improve peak bone density (PBD), whereas current occupational exercise and current sporting activities are important for maintaining maximum $\mathrm{BMD}^{(1-1)}$. There is general agreement that calcium intake (as a result of dietary pattern) is important during bone development. Meta-analyses of crosssectional studies have shown a statistically significant correlation between calcium intake and bone mass in pre-menopausal females ${ }^{(11.12,13)}$. Level of education may be relevant because highly educated women are supposed to have more sedentary job ${ }^{(14)}$. Furthermore, level of education may be related to the number of children (including voluntary childlessness) and dietary patterns.

The aim of the present study was to establish to what extent these osteoporosis related social and socio-economic factors might be able to predict the presence of osteoporosis and to what extent they could be used in osteoporosis prevention strategies in primary health care. Primary health care was chosen because the general practitioner (GP) is personally acquainted with his patient's physical health as well as their social and socioeconomic circumstances. These questions were investigated in a population-based crosssectional study including healthy postmenopausal women over the age of 50 . These women generally have a more active lifestyle than diseased women do. 


\section{METHODS}

\section{Population}

As has been described in previous reports, a cross-sectional population based study on the prevalence of osteoporosis in daily practice was performed between October 1992 and March 1994. 23 GPs in 12 GP centres indicated all 9107 women aged 50 - 80 on their register. According to a prescribed procedure, the GPs recruited all 5303 healthy postmenopausal women (the GPs decision on health status was made according to inclusion and exclusion criteria, see appendix F). These women, as well as $943(25 \%)$ of the remaining group (i.e. those initially excluded as 'not healthy' according to the inclusion and exclusion criteria) were invited to participate in the study. Of the 6246 invited women, 4725 have participated. The data of 522 women who had participated in a pilot study were excluded from further data analysis ${ }^{(15)}$. The remaining population (total population) consisted of 4203 women: 703 women who were initially excluded plus 3500 women who were initially included. The study population was obtained by leaving out from the initially included women all 1422 women who answered yes to the question 'are you suffering from any disease?' Data analysis was thus performed for 2078 (4203$(703+1422$ diseased women)\} healthy postmenopausal women (study population). In addition, comparisons were made with the group of $2125(703+1422)$ diseased women. (See also the flow chart:)

\section{Measurements}

Each visit started with measurements of body weight, height, body mass index (BMI) and BMD of the lumbar spine. The latter was measured using a computer guided DXA instrument (Hologic QDR-1000, Hologic Europe, Brussels, Belgium). With the help of the research nurse, patients then completed a questionnaire on variables possibly related to osteoporosis (e:g. biometrical and lifestyle data). In addition, all women were questioned in detail on their present and past sporting activities, their present and past occupation(s) and their number of children. Calcium intake was measured with the help of a validated questionnaire ${ }^{(16)}$.

\section{Statistics}

The BMDP program was used for statistical analysis ${ }^{(17)}$. BMD values (dependent variable) were dichotomised at $0.80 \mathrm{~g} / \mathrm{cm}^{2}$ (for asteoporosis) and $0.97 \mathrm{~g} / \mathrm{cm}^{2}$ (for osteopeniatosteoporosis = low $\mathrm{BMD})^{(18)}$. The cutoff points corresponded to 2.5 and 1 standard deviations below the mean BMD of the lumbar spine (L2-L4), measured in a healthy adult female population aged 30 , using the Hologic QDR-1000 ${ }^{(19,20)}$. Sporting activities in the past and at present were categorised into those without axial pressure (all kinds of aquatic sports and biking) and those with axial pressure (all other sports). 
Occupational exercise and level of education were classified according to the Occupational Guide (TTS-beroepenklapper) of The Netherlands Institute of Applied Social Studies ${ }^{(21)}$. Level of education was dichotomized into 1-2 and 3-7 on a 7-point scale. By way of example: housewives were categorized as level 1, seamstresses as level 2, geriatric helpers as level 3 and qualified nurses as 5. Physical strain on a person was used to categorise occupational exercise as mild, moderate or heavy. Occupational exercise was divided into all weight bearing activities (with axial pressure), and all others (without axial pressure). The number of children was dichotomized into having one or more children and being childless. Calcium intake was dichotomized into more or less than $500 \mathrm{mg}$ per day.

The relationship between BMD, age and weight was studied for the total population, the study population and in the category of diseased women. Social and socio-economic variables were analysed for the study population. Multivariate stepwise backward and forward logistic regression analyses (hereafter "regression analysis') were performed with the above social and socio-economic variables as well as with all discrete and dichotomized non-discrete variables that we had used in a previous study (summarized in appendix G). In order to check for intercollinearity, the product variables 'no job at present $\mathrm{X}$ no sporting activities at present', 'sporting activities with axial pressure at present $x$ sporting activities with axial pressure in the past' and 'occupational exercise with axial pressure at present $x$ sporting activities with axial pressure at present' were added to the model. The regression analyses were performed for the study population, as well as for the categories below and above the age of 65 .

\section{RESULTS}

The characteristics of the study population are shown in Table la (non-discrete variables) and table $1 \mathrm{~b}$ (discrete variables). They were similar to those of the total population. Table 2 represents the prevalence of osteoporosis in six age categories. For women aged 65 or over, the percentage of osteoporosis in healthy women was statistically significantly different from that in diseased women $\left(\mathrm{OR}=1.8 ; \mathrm{Cl}_{3} 1.42 .2\right)$. Comparable findings were made regarding weight $(\mathrm{OR}=1.5 ; \mathrm{Cl}, 1.2-1.8)$. For women below the age of 65 , these differences were not statistically significant. Figures 1 and 2 show the relationship between age and the presence of osteoporosis, categorized for being healthy or diseased. These figures reveal that osteoporosis was systematically more common in healthy women, regardless of age. Table 3 shows the results of bivariate analysis between present social and socio-economic status and $\mathrm{BMD}$, categorized for age. We found no consistent influence whatsoever of sociall and socio-economic factors on BMD. Even the comparison between the unfavourable situation (no job and no sporting activities) and the 
more optimal situation (presence of sporting activities with axial pressure and the presence of occupational exercise with axial pressure) did not come up with significant differences.

Table 4 shows the results of the regression analyses. Only variables with statistically significant ORs for the presence of osteoporosis or low BMD are shown. Apart from the previously found statistically significant determinants of $\mathrm{BMD}$, only low calcium intake, heavy occupational exercise in the past and sporting activities with axial pressure in the past were found to be statistically significant related to BMD. However, this was only found in the category of women below the age of 65 . In the category of healthy women over 65 , weight was the strongest predictor of osteoporosis. In this category, only two variables were statistically significantly associated with the presence of low $\mathrm{BMD}$, viz. age and number of fertile years. When the analyses were repeated for the total study population, they revealed results similar to those for the subgroup below the age of 65 .

\section{DISCUSSION}

The decision on health status (healthy or diseased) was made by the patient by answering the question 'are you suffering from any disease'. We did not verify their decision otherwise than by comparing the answers on that question with the answer on the question 'are you currently under treatment of your GP or a specialist'; we could not find any irregularities.

Social and socio-economic factors added little to the relationship between age and BMD. Only a few of these factors were statistically significant in the category of women below the age of 65. A previous study had shown that age and weight were the most prominent determinants of BMD in women over 65 . Apparently, the influence of one's socioeconomie past diminishes with advancing age. However, heavy occupational exercise in the past is a strong and independent determinant of osteoporosis in women below the age of 65 . In this category, its importance is comparable to that of a recent history of fractures. The fact that age is the most consistent determinant of BMD suggests that osteoporosis is a typically degenerative condition. This association is more evident in healthy than in diseased women. The results reveal a considerable rolle for weight. In all age categories, weight explains the different prevalences of osteoporosis in the categories of healthy and diseased women. Actually, weight modifies the effect of age on BMD illustrating that osteoporosis certainly is an active process. Social and socio-economic factors are important determinants of physical health, whereas physical health as defined by the patient who reports not to be suffering from any disease is statistically significant associated with the presence of osteoporosis. Hence, the investigated factors apparently behave as effect modifiers of age and physical health. 
As regards osteoporosis prevention strategies in primary health care, the use of social and socio-economic factors in the management of osteoporosis is probably not very helpfill. In contrast with the findings from our previous study (performed in an unselected population), the present study (performed in healthy subjects) showed a linear age-related decrease in BMD. Many other studies have found a similar relationship. On the basis of our findings, we conclude that these studies must have been performed among rather healthy patients with a relatively low weight (and with a relatively small number of patients over 65). The results of The Rotterdam Study, which used a population with similar characteristics, confirm our conclusion ${ }^{(15,22)}$.

Flow chart.

\begin{tabular}{|c|c|c|c|}
\hline s & $100 \%$ & \multicolumn{2}{|c|}{9107 women aged $50-80$ years identified in 12 general practice centres } \\
\hline Identified by 23 GPs & $\therefore$ & 5303 postmenopausal healthy women & 3804 not healthy women \\
\hline Selected for participation & $69 \%$ & 5303 & $943(25 \%$ of 3804$)$ \\
\hline Invited & $69 \%$ & \multicolumn{2}{|c|}{6246} \\
\hline Participated ( $76 \%$ of 6246$)$ & $52 \%$ & \multicolumn{2}{|c|}{4725} \\
\hline Informed consent obtained & & \multicolumn{2}{|c|}{4725} \\
\hline First four weeks, pilot study & $\vdots$ & \multicolumn{2}{|c|}{-516} \\
\hline DEXA measurement failed & & \multicolumn{2}{|r|}{-6} \\
\hline \multirow[t]{2}{*}{ Used for statistical analysis } & $46 \%$ & 3500 & 703 \\
\hline & $46 \%$ & \multicolumn{2}{|c|}{4203} \\
\hline $\begin{array}{l}\text { Answer = NO } \\
\text { Answer = YES } \\
\text { to the question are you suffering } \\
\text { from any disease? }\end{array}$ & : & $\begin{array}{ccc}2078 & 1422 \\
& & \\
& & \\
\end{array}$ & $\therefore$ \\
\hline Healthy women & $23 \%$ & 2078 & \\
\hline Diseased women & $23 \%$ & 1422 & 703 \\
\hline
\end{tabular}

Table 1a. Description of the study population, non-discrete variables, compared with the total population.

\begin{tabular}{|c|c|c|c|c|c|c|c|c|}
\hline $3 \quad$ & \multicolumn{4}{|c|}{ study population $(\mathrm{n}=2078)$} & \multicolumn{4}{|c|}{ Total population $(\mathrm{n}-4203)$} \\
\hline$\therefore$ & mean & $(\mathrm{SD})$ & median & $(Q 1-Q 3)$ & mean & (SD) & medi & $(\mathrm{Q} 1-\mathrm{Q} 3)$ \\
\hline $\mathrm{BMD}\left(\mathrm{g} / \mathrm{cm}^{2}\right)$ & 0.910 & $(0.155)$ & 0.910 & $(0.800-1.004)$ & 0.925 & $(0.163)$ & & $(0.811-1.023)$ \\
\hline age (years) & 62 & (7) & $62 !$ & $(56-67)$ & 63 & (7) & 62 & $(57-68)$ \\
\hline weight (kg) & 70 & (11) & 70 & $(62-77)$ & 71 & $(12)$ & 70 & $(63-78)$ \\
\hline height (cm) & 161 & (6) & 161 & $(157-165)$ & 161 & $(6)$ & 161 & $(157-165)$ \\
\hline $\mathrm{BMI}\left(\mathrm{kg} / \mathrm{m}^{2}\right)$ & 27 & (4) & 27 & $(24-29)$ & 27 & $(5)$ & 27 & $(24-30)$ \\
\hline number of ehildren & 3 & (2) & 3 & $(2-4)$ & 3 & (2) & 3 & $(2-4)$ \\
\hline calcium intake & 876 & (394) & 805 & $(599-1087)$ & 874 & (399) & 804 & $(\$ 98-1084)$ \\
\hline
\end{tabular}


Table 1 . Description of the study population $(n=2078)$ discrete wariables. Numbers of patients $(\%)$ are given

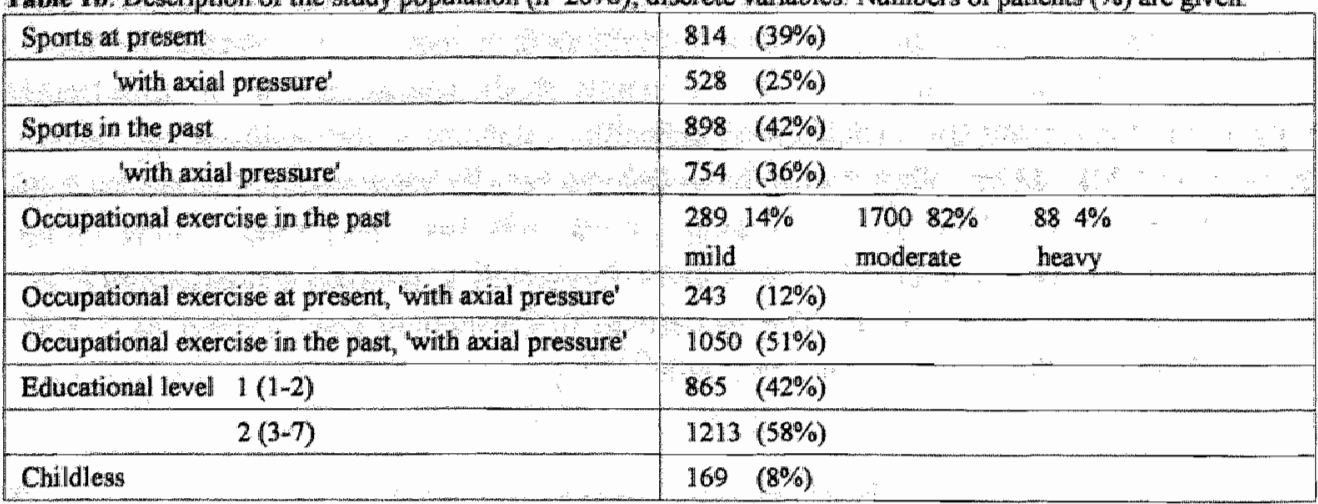

Table 2. Prevalence of osteoporosis in the total population, related to age and categorized for being healthy (study population) or discased.

\begin{tabular}{|c|c|c|c|c|c|c|}
\hline \multicolumn{7}{|c|}{ Total population of 4203 postmenopausal women aged $50-80$ years. } \\
\hline Age & $50-54$ & $55-59$ & $60-64$ & $65-69$ & $70-74$ & $75-80$ \\
\hline Number of patients & 689 & 976 & 975 & 761 & 546 & 256 \\
\hline Weight in $\mathrm{kg}$ & 71 & 71 & 72 & 72 & 72 & 71 \\
\hline Mean BMD $\mathrm{g} / \mathrm{cm}^{2}(\mathrm{SD})$ & $0.99(0.16)^{*}$ & $0.94(0.16)$ & $0.90(0.15)$ & $0.90(0.16)$ & $0.91(0.17)$ & $0.89(0.18)$ \\
\hline $\begin{array}{l}\text { Prevalence of } \\
\text { asteoporosis }\end{array}$ & $10 \%$ & $18 \%$ & $26 \%$ & $29 \%$ & $30 \%$ & $38 \%$ \\
\hline \multicolumn{7}{|c|}{ Healthy postmenopausal women $(\mathrm{m}=2078)$} \\
\hline Number of patients & 399 & 557 & 455 & 357 & 224 & 86 \\
\hline Weight in $\mathrm{kg}$ & 70 & 71 & 71 & 71 & 69 & 65 \\
\hline Mean $B M D g / \mathrm{cm}^{2}(S D)$ & $0.97(0.15)$ & $0.93(0.15)$ & $0.89(0,15)$ & $0.88(0.16)$ & $0.87(0.15)$ & $0.84(0.15)$ \\
\hline $\begin{array}{l}\text { Prevalience of } \\
\text { osteoporosis }\end{array}$ & $12 \%$ & $18 \%$ & $27 \%$ & $33 \%$ & $39 \%$ & $51 \%$ \\
\hline \multicolumn{7}{|c|}{ Diseased postmenopausal women $(\mathrm{n}=2125)$} \\
\hline Number of patients & 290 & 419 & 520 & 404 & 322 & 170 \\
\hline Weight in $\mathrm{kg}$ & 72 & 72 & 72 & 74 & 75 & 75 \\
\hline $\mathrm{N}\left(\mathrm{c} \sin \mathrm{BMD} \mathrm{g} / \mathrm{cm}^{2}(\mathrm{SD})\right.$ & $100(0.17)$ & $0.96(0.16)$ & $0.92(0.16)$ & $0.92(0.16)$ & $0.94(0.18)$ & $0.9 \|(0.18)$ \\
\hline $\begin{array}{l}\text { Prevalence of } \\
\text { osteoporosis }\end{array}$ & $7 \%$ & $17 \%$ & $26 \%$ & $25 \%$ & $23 \%$ & $30 \%$ \\
\hline
\end{tabular}

BMD values have been rounded off. 
Prevalences of osteoporosis per age category in the total papulatwon (n 4203 )

as well as categorized for being healthy $(n=207 / 8)$ or diseased $(x-2125)$

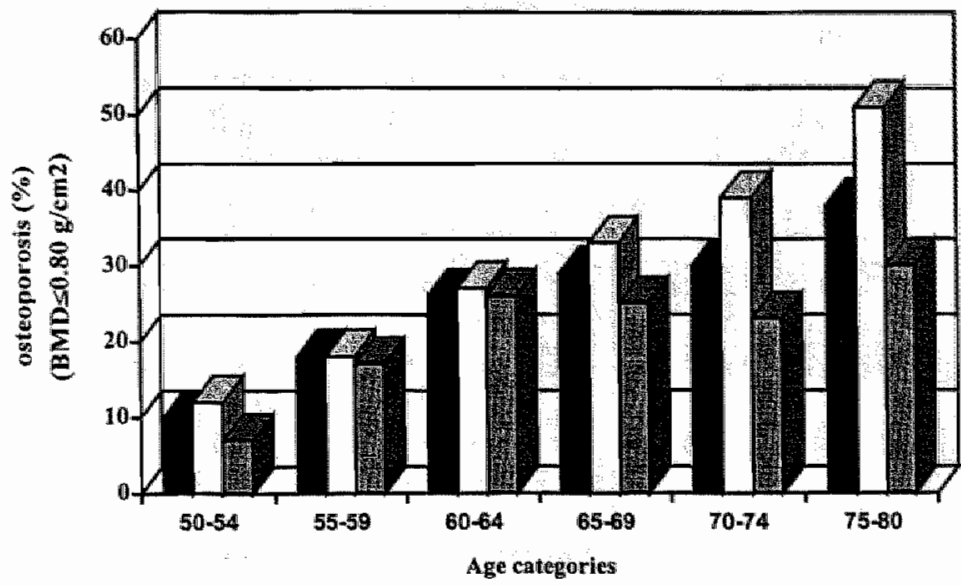

DTotal popalation QHealthy women

andeased women

frguur 1

Relationship between age and BMD in the total population ( $\mathrm{n}=4203$ ) as well as categorized for being healthy $(n-2078)$ or diseased $(n=2125)$

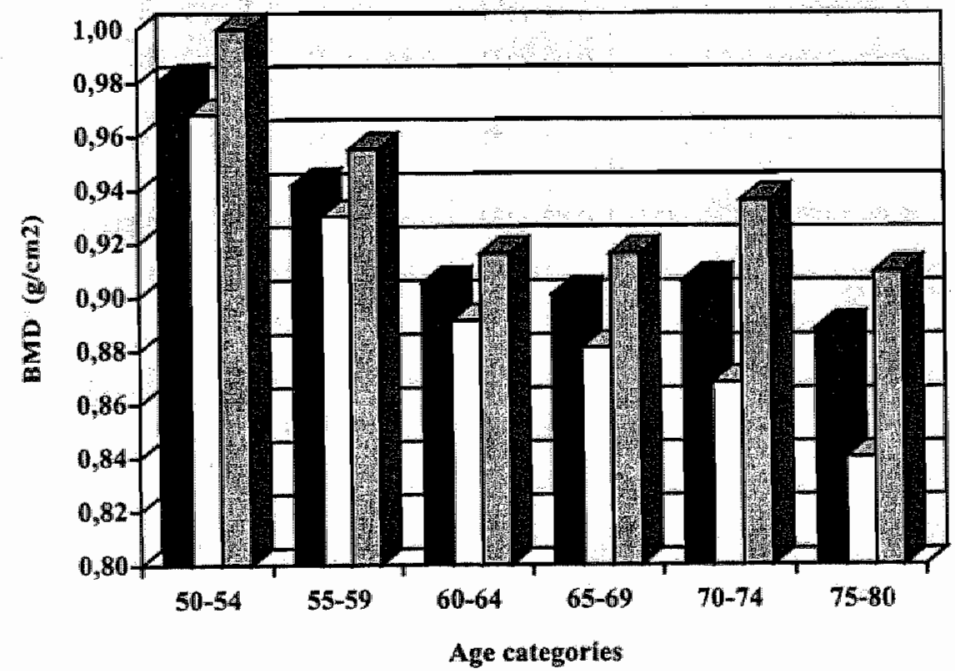

figuur 2 
Table 3. Relationship between social and sociomeconomic factors and BMD, related to age, in the study population

\begin{tabular}{|c|c|c|c|c|c|c|}
\hline \multirow[b]{2}{*}{ Age categonies (years) } & \multicolumn{6}{|c|}{$\mathrm{BMD} \mathrm{g} / \mathrm{cmn}^{2}(\mathrm{n}) *$} \\
\hline & $50-54$ & $55-59$ & $60-64$ & $65-69$ & $70-74$ & $75-80$ \\
\hline All patients & $0.97(399)$ & $093(557)$ & $0.89(455)$ & $0.88(357)$ & $0.87(224)$ & $0.85(86)$ \\
\hline $\begin{array}{l}\text { Sporting activities at } \\
\text { present }\end{array}$ & $099(159)$ & $0.93(2.12)$ & $0.88(187)$ & $0.88(137)$ & $0.88(55)$ & $0.82(26)$ \\
\hline $\begin{array}{l}\text { No sporting activities at } \\
\text { present }\end{array}$ & $096(240)$ & $0.93(345)$ & $0.90(268)$ & $0.88(220)$ & $0.86(169)$ & $0.85(60)$ \\
\hline $\begin{array}{l}\text { Sporting activities with } \\
\text { axial pressure, at present }\end{array}$ & $0.98(109)$ & $0.94(124)$ & $0.87(138)$ & $0.87(94)$ & $0.88(43)$ & $0.81(20)$ \\
\hline $\begin{array}{l}\text { Sporting activities without } \\
\text { axial pressure, at present }\end{array}$ & $100(50)$ & $0.93(88)$ & $0.90(49)$ & $0.92(43)$ & $0.87(12)$ & $0.84(6)$ \\
\hline $\begin{array}{l}\text { Sporting activitiess and } \\
\text { occupational exercise with } \\
\text { axial pressure, at present }\end{array}$ & $0.99(27)$ & $0.98(28)$ & $0.87(10)$ & $0.94(5)$ & $0.86(4)$ & (0) \\
\hline $\begin{array}{l}\text { Occupational exercise } \\
\text { with axial pressure, } \\
\text { at present }\end{array}$ & $1.00(103)$ & $0.96(80)$ & $0.90(35)$ & $0.96(11)$ & $0.82(13)$ & $0.75(1)$ \\
\hline $\begin{array}{l}\text { No occupational exercise, } \\
\text { at present }\end{array}$ & $0.96(296)$ & $0.93(477)$ & $0.89(420)$ & $0.88(346)$ & $0.87(211)$ & $0.84(85)$ \\
\hline Education level $\leq 2$ & $0.96(111)$ & $0.92(235)$ & $0.88(187)$ & $0.89(163)$ & $0.85(116)$ & $0.83(53)$ \\
\hline Education level $\geq 3$ & $0.97(288)$ & $0.93(322)$ & $0.90(268)$ & $0.88(192)$ & $0.88(108)$ & $0.85(33)$ \\
\hline Childless & $1.01(25)$ & $0.95(53)$ & $0.91(34)$ & $0.88(43)$ & $0.89(35)$ & $0.89(12)$ \\
\hline Children & $0.97(374)$ & $0.93(504)$ & $0.89(421)$ & $0.88(314)$ & $0.87(189)$ & $0.84(74)$ \\
\hline $\begin{array}{l}\text { No job and no sports at } \\
\text { present }\end{array}$ & $0.94(176)$ & $0.93 \cdot(293)$ & $0.90(243)$ & $0.88(214)$ & $087(160)$ & $0.85(59)$ \\
\hline $\begin{array}{l}\text { calcium intake } \\
\leq 500 \mathrm{mg} / \text { day }\end{array}$ & $0.93(59)$ & $091(69)$ & $0.89(72)$ & $0.90(58)$ & $0.83(34)$ & $0.85(12)$ \\
\hline $\begin{array}{l}\text { calcium intalke } \\
>500 \mathrm{mg} / \mathrm{day}\end{array}$ & $0.98(340)$ & $0.93(488)$ & $0.89(383)$ & $0.88(299)$ & $0.88(190)$ & $0.84(74)$ \\
\hline
\end{tabular}

- BMD values have been rounded off 
Table 4. Statistically significant results of regression analysis. Odds ratios (OR) and their $95 \%$ confidence intervals (CI) are shown.

\begin{tabular}{|c|c|c|c|c|c|c|}
\hline & \multicolumn{2}{|c|}{ Age $\leq 65$ years $(n=1411)$} & \multicolumn{2}{|c|}{ Age $>65$ years $(\mathrm{n}=667)$} & \multicolumn{2}{|c|}{ Study population $(\mathrm{n}=2078)$} \\
\hline & osteoporosis: & low BMD * & Osteoporosis & Low BMD & osteoporosis & Low BMD \\
\hline & OR (CI) & $\mathrm{OR}(\mathrm{CD})$ & OR $(\mathrm{CD})$ & $\mathrm{OR}(\mathrm{CD})$ & OR $(\mathrm{C})$ & OR $(\mathrm{Cl})$ \\
\hline $\begin{array}{l}\text { Age, } \\
\text { over } 60 \text { years }\end{array}$ & $2.1(1.6-2.9)$ & $1.8(1.4-2.3)$ & & $2.5(1.7-3.8)$ & $2.5(20-32)$ & $1.7(1.4-2.1)$ \\
\hline $\begin{array}{l}\text { Weight, } \\
\text { under } 70 \mathrm{~kg}\end{array}$ & & $1.5(1.1-2.1)$ & $2.8(1.9-4.1)$ & 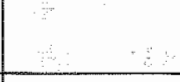 & $1.7(1.3-2.4)$ & $1.6(1.3-2.2)$ \\
\hline $\begin{array}{l}\text { Height, } \\
\text { under } 160 \mathrm{~cm}\end{array}$ & $1.6(1.2-2.2)$ & $1.4(1.1-1.9)$ & $16(1.1-2.2)$ & & $1.7(1.3-2.1)$ & $1.3(1.0-1.6)$ \\
\hline $\begin{array}{l}\mathrm{BMI}, \\
\text { under } 27 \mathrm{~kg} / \mathrm{m}^{2}\end{array}$ & $1.9(1.2-2.8)$ & $1.6(1.1-2.2)$ & 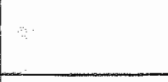 & & $1.7(1.2-2.3)$ & $1.4(1.0-11.9)$ \\
\hline $\begin{array}{l}\text { Fracture } \\
\text { during past } 5 \text { years }\end{array}$ & $2.0(1.2-3.4)$ & $2.4(1.4-4.2)$ & $1.8(1.0-3.1)$ & & $1.9(1.3-2.8)$ & $1.8(1.2-2.8)$ \\
\hline $\begin{array}{l}\text { Use of the pill for } \\
\text { more than } 5 \text { years }\end{array}$ & $0.6(0.4-0.9)$ & $0.7(0.5-1.0)$ & & & $0.5(0.4-0.8)$ & $0.7(0.5-0.9)$ \\
\hline $\begin{array}{l}\text { Ovariectomy } \\
\text { in history }\end{array}$ & 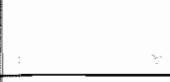 & $1.7(1.1-2.5)$ & 2 & 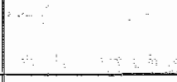 & & $1.5(1.1-2.2)$ \\
\hline $\begin{array}{l}\text { Hysterectomy } \\
\text { in thistory }\end{array}$ & & $0.5(0.4-0.7)$ & 6 & & & $0.7(0.5-0.9)$ \\
\hline $\begin{array}{l}\text { Menopause } \\
\text { before the age of } 45\end{array}$ & 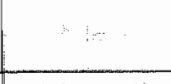 & $1.5(1.1-2.1)$ & . & & & \\
\hline $\begin{array}{l}\text { Less than } 35 \text { fentile } \\
\text { years }\end{array}$ & $1.7(1.2-2.3)$ & $1.5(1.1-1.9)$ & & $1.5(1.0-22)$ & $1.3(1.1-1.7)$ & $1.6(1.3-1.9)$ \\
\hline $\begin{array}{l}\text { Perimenopausal } \\
\text { complaints in } \\
\text { history }\end{array}$ & & & $0.6(0.3-1.0)$ & & $0.7(0.5-1.0)$ & \\
\hline $\begin{array}{l}\text { Positive family } \\
\text { history of fractures }\end{array}$ & $1.6(1.1-2.5)$ & & & 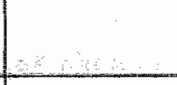 & $1.6(1.1-2.3)$ & \\
\hline $\begin{array}{l}\text { Sporting activities } \\
\text { with axial pressure } \\
\text { in the past }\end{array}$ & & $0.8(0.6-1.0)$ & 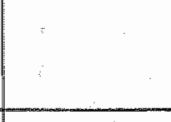 & $\therefore$ & & \\
\hline $\begin{array}{l}\text { Heavy occupational } \\
\text { exercise in the past }\end{array}$ & $2.7(1.3-5.6)$ & & & & $2.3(1.3-4.1)$ & $\because$ \\
\hline $\begin{array}{l}\text { Calcium intake } \\
\text { less than } 500 \mathrm{mg}\end{array}$ & $11.6(1,1-2.3)$ & & & & & \\
\hline
\end{tabular}

- Osteoporosis = BMD lumbar spine (L2-LA) $\leq 0.800 \mathrm{~g} / \mathrm{cm}^{2}$, low BMD $=$ BMD $\leq 0.970 \mathrm{~g} / \mathrm{cm}^{2}$ 


\section{REFERENCES}

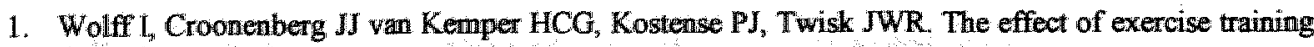
programs on bone mass: a meta-analysis of published controlled trials in pre- and postmenopausal women Osteoporosis Int 1999;9:1-12

2. Greendale GA, Banrett-Connor E, Edelstein S, Ingles S, Halle R. Lifetime leisure exercise and osteoporosis. The Rancho Bemardo Study. Am J Epidemiol 1995;141:961-9

3. Nelson ME, Fiatarone MA, Morganti CM, Trice 1, Gimeenberg RA, Evans WJ. Effects of highintensity strength training on multiple risk factors for osteoporotic fractures. A randomized controlled trial. JAMA 1994;28:1909-31

4. Kannus PK, Haapasalo $H_{4}$, Sankelo $\mathrm{M}$, Sievänen $\mathrm{H}_{2}$ Pasamen $\mathrm{M}$, Heinonen $\mathrm{A}$, et al. Effect of starting age of physical activity on bone mass in the dominant anm of tennis and squash players. Ann Intern Med 1995;123:27-31

5. Boot AM, de Ridder MAJ, Pols HAP, Krenning EP, de Muinck Keizer-Schrama SMPF. Bone mineral density in children and adolescents: relation to puberty, calcium intake and physical activity. J Clin Endocrinol Metab 1997;82:57-62

6. Marken Lichtenbelt WD van, Fogelholm M, Ottenheijm R, Westerterp KR. Physical activity, body composition and bone density in ballet dancers. British J mutrition 1995;74:439-51

7. Carter DR, Meulen MCH van der, Beaupre GS. Mechanical factors in bone growth and development. Bone 1966;18:5s-10s

8. Snow-Harter $\mathrm{C}_{\mathrm{n}}$ Whalen $\mathrm{R}$, Myburgh $\mathrm{K}$, Amaud S, Marcus $\mathrm{R}$. Bone mineral density "muscle strength, and recreational exercise in men. J Bone Miner Res 1992;7:1291-6

9. Smith EL, Gilligan C. Dose-response relationship between physical loading and mechamical competence of bone. Bone 1996; 18:45s-50s

10. Chesnut CH III. Bone mass and exercise. 1993;95(suppl 5s):34s-35s

11. Celloti $F$, Bignamine A. Dietary calcium and mineral/vitamin supplementation: a contro-versial problem. J Intern Med Res 1999;27:1-114

12. Welten DC, Kemper HCG, Post GB, Van Staveren WA. A meta-analysis of the effect of calcium intake on bone mass in young and middle aged females and males. J Nurr 1995;125:2802-13

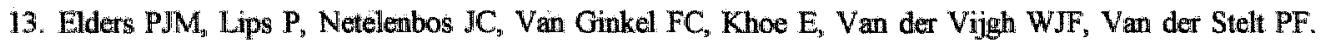
Long-term effect of calcium supplennentation on bone loss in perimenopausal women. $J$ Bone Miner Res $1994: 9963-70$

14. Statistisch Jaarboek 1995. s'Gravenhage: Centraal bureau voor de statistiek, 1995

15. Van der Voort DJM, Dinant GJ, Rinkens PELM, Van der Voort-Duindam CJM, Van Wersch JWJ, Geusens PP. Diagnostic accuracy of an algorithm for quick detection of patients with low bone mineral density in everyday general practice. Accepted for $J$ Clin Epidemiol

16. O'Neill TW, Cooper C, Cannata JB, Diaz Lopez JB, Hoszowiski K, Johnell O, et al. Repro-ducibility of a questionnaire on risk factors for osteoporosis in a multicentre prevalence survey: The European Verteral Osteoporosis Study.Int J Epidemioll 1994;23:559-65

17. Dixon WJ, Brown MB, Engelman L, Holl MA, Jenrich RI. BMDP statistical software manual. Berkelley University of California Press, 1990 
18. Assessment of fracture risk and its application to sereening for postmenopausal osteoporosis, Geneva: WHO Technical report series 843, 1994

19. Bone Density Reference Data. Bruxelles: S.A. Hologic Europe.

20. Steiger $\mathrm{P}$, Cummings SR, Black DM, Spencer NE, Genant HK. Age-related decrements in bone mineral density in women over 65. J Bone Miner Res 1992;7:625-32

21. TS-Beroepenklapper. The Netherlands Institute of Applied Social Studies.

22. Burger $H$, Van Dale PLA, Algra D, Van den Ouweland FA, Grobbee DE, Hofman $A_{x}$ et al. The association between age and bone mineral density in men and women aged 55 years and over: The Rotterdam Study. Bone Miner 1994;25:1-13.

\subsection{Samenvatting}

Doelstelling. Het bepalen tot op welke hoogte de aan osteoporose gerelateerde sociaaleconomische factoren de aanwezigheid van osteoporose kunnen voorspellen. De tweede doelstelling was vast te stellen in hoeverre deze factoren kunnen worden gebruikt bij de preventie van osteoporose bij gezonde postmenopauzale vrouwen met een leeftijd tussen 50 en 80 jaar, in de huisartsenpraktijk.

Studie design. 'Cross-sectional population-based' studie.

Patiënten en methoden. De studiepopulatie bestond uit 2078 gezonde postmenopauzale vrouwen in de leeftijd van 50-80 jaar, uit de praktijken van 23 huisartsen. De vrouwen werden onderzocht (gewicht, lengte, body mass index (BMI) en botmineraaldichtheid (BMD) van de lumbale wervelkolom) en ondervraagd over variabelen die mogelijk gerelateerd waren aan osteoporose. Tot deze variabelen behoorden sportbeoefening, beroep en opleidingsniveau, aantal kinderen en calciuminame (hierna te noemen de sociale en sociaal - maatschappelijke factoren).

Statistiek. We voerden bivariabele analyses uit om de relatie te onderzoeken tussen de sociale en sociaal-maatschappelijke factoren en de MBD in relatie tot de leeftijd. De cutpoints voor de BMD van de lumbale wervelkolom (L2-L5) waren $0,800 \mathrm{gr} / \mathrm{cm}^{2}$ voor osteoporose en $0,970 \mathrm{gr} / \mathrm{cm}^{2}$ voor lage BMD. Multivariabele stepwise backward and forward logistische regressie analyses werden uitgevoerd met de hierboven genoemde variabelen die we toevoegden aan de onafhankelijke variabelen uit hoofdstuk 3. Alle analyses werden gedaan voor de totale studiepopulatie en de subgroepen jonger en ouder dan 65 jaar.

Resultaten. In de leeftijdsgroep ouder dan 65 jaar, zijn gezonde vrouwen statistisch significant vaker osteoporotisch, en hebben een lager gewicht dan zieke vrouwen $(O R=1,8$; CI, 1,4-2,2 voor osteoporose en $\mathrm{OR}=1,5, \mathrm{Cl}, 1,2-1,8$ voor gewicht lager dan $70 \mathrm{~kg}$ ). Er werd geen consistente invloed aangetoond van de sociale en sociaal-maatschappelijke 
factoren op de BMD. Buiten de al eerder aangetoonde statistisch significante determinanten van de BMD bleken alleen de calciuminname, zware werkbelasting in het verleden en in het verleden uitgevoerde sportieve activiteiten met rugbelasting significant te zijn geassocieerd met de BMD. Dit gold overigens alleen de leeftijdscategorie jonger dan 65 jaar. In alle leeftijdscategorieên verklaart het gewicht de verschillen in prevalentie van osteoporose tussen de subgroepen gezonde en zieke vrouwen.

Conclusies. Het gegeven dat de leeftijd de meest consistente determinant is van de BMD suggereert dat osteoporose een typisch degeneratieve ziekte is. Deze associatie is duidelijker bij gezonde dan bij zieke vrouwen. In feite modificeert de factor gewicht het effect van de leeftijd op de BMD en laat zien dat osteoporose een actief proces is. Bij de preventie van osteoporose in de eerste lijn spelen sociaal-maatschappelijke factoren slechts een geringe rol. In tegenstelling met de bevindingen in hoofdstuk 3 (een studie die werd uitgevoerd onder een niet geselecteerde populatie) laat dit onderzoek (onder gezonde vrouwen) een lineair verband zien tussen de leeftijd en de BMD.

In vele andere studies werd dezelfde relatie aangetoond. Op basis van onze bevindingen concluderen we dat die studies werden uitgevoerd onder voornamelijk gezonde patiënten (met een relatief laag gewicht) in een studiepopulatie met relatief weinig patiënten ouder dan 65 jaar.

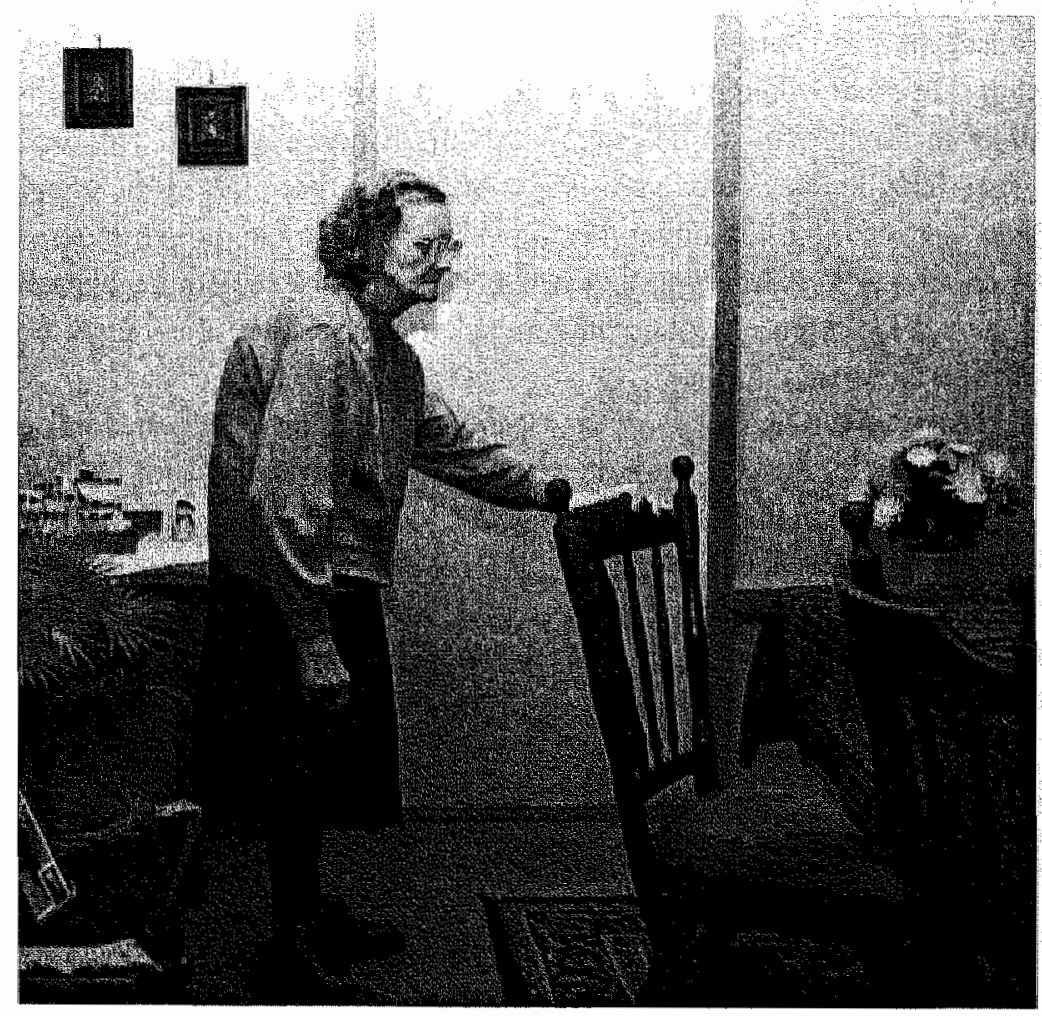




\section{Hoofdstuk 8}

\section{Beschouwing}

In deze beschourwing worden, na een terugblik op het studiedesign, de resultaten van het onderzoek gerelateerd aan de vrangstellingen. Enerzijds gaan we na of het onderzoek de antwoorden op de vraagstellingen heeft opgeleverd, anderzijds wat er gedaan moet worden om de door het onderzoek gerezen vragen te beantwoorden.

In hoofdstuk 1.2 wordt het studiedesign in extenso beschreven. Het design behelst een cross-sectionele studie. Een studie die echter vrijwel uitslluitend gebruik maakt van variabelen met een longitudinaal karakter. Elke ziekte heeft een specifiek beloop, dus is er sprake van een tijdsaspect (duur). Vooral de effecten van lifestyle factoren worden bepaald door de tijdsduur dat ze aanwezig zijn. Dit tijdsaspect voegt longitudinale kenmerken toe aan de cross-sectionele studie. Daar waar we expliciet het verband onderzoeken tussen vroegere en huidige BMI, is onze studie longitudinaal. Dat neemt echter niet weg, dat de resultaten van onze studie door prospectieve studies moeten worden getoetst. We zijn dan ook blij dat inmiddels een aselecte steekproef uit onze studiepopulatie voor een vervolgmeting is geweest. In dit vervolgonderzoek nemen we ook variabelen mee als: spierkracht, botombouw parameters en genetische parameters. De resultaten van die studie zullen vanzelfsprekend worden gerelateerd aan de resultaten die in dit proefschrift zijn beschreven.

Het onderzoek naar de verschillen, als determinanten van de ziekte, tussen de zieken (osteoporotische vrouwen en/of vrouwen met een fractuur) en gezonden (deze beide groepen zijn afkomstig uit dezelfde bronpopulatie), vertoont grote overeenkomsten met het design van een patiënt-controle-onderzoek (PCO). De studie voldoet aan de voorwaarden die worden gesteld aan een PCO: de wijze waarop de controle groep moet worden samengesteld, het voorkómen van selectie-bias en van informatie-bias. De grootte van de door ons onderzochte populatie in verhouding tot de bronpopulatie (52\%), maakt uitspraken mogelijk in termen van relatieve risico' $\mathrm{s}$, prevalentie van osteoporose en incidentie van fracturen ${ }^{(1)}$.

Een lastig aspect in het studie design was het opzetten van een procedure om nonresponders te onderzoeken. Op pagina 35 wordt toch een kleine groep non-responders uit de praktijk van de onderzoeker beschreven. Deze groep bestaat uit die vrouwen die tijdens de studieperiode om welke reden dan ook, in contact kwamen met de onderzoeker. Een nadere beschouwing van deze groep non-responders leert, dat ook het aantal ziekten dat voorkomt onder de non-responders gelijk is aan het percentage ziekten in de totale studiepopulatie. 
Deze resultaten maken het minder waarschijnlijk dat de non-responders, voor wat betreft het voorkomen van osteoporose, wezenlijk verschillen van de responders.

Een positief aspect van het design was het resultaat van de oproepprocedure. Door de medewerking van de praktijkassistentes van de deelnemende huisartsen ${ }^{1}$ werd een hoge opkomst bereikt. De assistentes belden de patiènten, vroegen hen om deelname aan het onderzoek en maakten direct een afspraak. Hierbij zal de, door ons verzorgde, vervoersvoorziening wellicht een niet onbelangrijke positieve rol gespeeld hebben. De vervoersvoorziening was onderdeel van een complexe logistiek. Zoals beschreven in hoofdstuk 1.2, moesten, om de continuïteit van een dergelijke studie te waarborgen, een groot aantal stappen (oproepen, afspreken, halen, meten, brengen) goed op elkaar zijn afgestemd.

Om te onderzoeken of de gevonden resultaten generaliseerbaar zijn naar de totale Nederlandse populatie van vrouwen tussen 50 en 80 jaar, maakten we vergelijkingen tussen onze bevindingen en die van het Registratienet Huisartsen (RNH) en van het Nijmeegse Continue Morbiditeit Registratie project (CMR). Het percentage patiënten met diabetes mellitus in de subgroep 65-75 jarigen van onze studiepopulatie bleek gelijk aan het percentage dat werd gevonden in het CMR ( $7 \%$ van de $65-75$ jarige vrouwen die zich bij de huisarts presenteren met klachten zijn diabeten). Het percentage vrouwen, dat in ons onderzoek aangeeft aan een hart- of vaatziekte te lijden, is $16,5 \%$. Van deze vrouwen is $16 \%$ alleen onder behandeling van de specialist, dus $14 \%$ van alle vrouwen is wegens een hart- of vaatziekte onder behandeling van de huisarts. Dit percentage komt overeen met de percentages die worden opgegeven door het RNH en het CMR. Voor wat betreft de biometrie is de studiepopulatie vergeleken met gegevens van het Centraal Bureau voor de Statistiek (CBS), De Rotterdam Studie en de gegevens uit een onderzoek van het Toegepast-Natuurwetenschappelijk Onderzoek (TNO) (pagina37, table 3). Indien de subjectieve lengte (pagina 53, table 1) en het subjectieve gewicht (niet gepubliceerd, kleine steekproef) in de vergelijking worden betrokken is er sprake van volledige overeenstemming. Voor het beschouwen van diabetes mellitus en hart- en vaatziekten pleit dat patiënten die aangeven aan deze aandoeningen te lijden, in het algemeen ook bij de huisarts bekend zijn. De prevalenties in onze studie, die in de registraties van het $\mathrm{RNH}$ en die van het CMR zijn daarom vergelijkbaar. De vergelijking gaat echter mank indien we aandoeningen als artrose, of klachten als rugklachten, buikpijn of overgangsklachten zouden gebruiken. In onze studie registreerden we immers ook aandoeningen en klachten van hen die de dokter niet consulteerden.

Het onderscheiden van de subgroepen 'consulting patients' en 'non-consulting patients' werd gedaan op basis van het gegeven, dat osteoporose een aandoening is met een zeer

'met huisarts wordt zowel mannelijke als vrouwelijke huisarts bedoeld 
langdurig beloop. In de subgoep vrouwen die de huisarts niet (frequent) consulteren moet tenminste het voorstadium van de ziekte (osteopenie), als ook osteoporose zonder fracturen, veelvuldig voorkomen. Wanneer we de eerder genoemde subgroepen vervolgens vergelijken (tabel 5 op pagina 22 en de tabellen 6 op pagina 23 en 24), dan valt op dat er; naast de grote mate van overeenstemming tussen de subgroepen, twee kenmerken zijn die in verschillende frequenties voorkomen: het al of niet aanwezig zijn van een ziekte en het gebruik van de pil. Voor het eerste is de verklaring volstrekt voor de hand liggend; voor het tweede kunnen we geen goede verklaring geven, of het moet zijn dat de pilgebruiksters van destijds de weg naar de dokter gemakkelijker blijven bewandelen.

De beantwoording van vraagstelling 1 (wat is de prevalentie van osteoporose onder postmenopauzale vrouwen van 50 tot 80 jaar) lijkt niet op problemen te stuiten. Het meten van de BMD van een groot aantal vrouwen uit de bronpopulatie zou het antwoord moeten opleveren. Aanvankelijk hanteerden wij een BMD van 2 SD beneden de piekbotdichtheid als afkappunt; een statistisch onderbouwd afkappunt om de patienten te kunnen onderscheiden in wel of niet 'normaal' en daarmee in wel of niet osteoporotisch. Dit afkappunt kwam eveneens overeen met de 'fractuurgrens' van $-2 \mathrm{SD}$, zoals beschreven door Meunier c.s. ${ }^{(2)}$. De WHO kwam in 1994 met de nieuwe definiëring. De operationele variant daarvan gebruikend blijkt dat $23 \%$ van de vrouwen van $50-80$ jaar in onze totale studiepopulatie osteoporotisch is. Deze conclusie wordt gesteld op grond van de BMDmetingen van de lendenwervelkolom en lokt daarom commentaar uit. Immers, het meten van de BMD van de wervels levert problemen op als er gelijktijdig sprake is van degeneratieve afwijkingen ter plaatse van de BMD-meting. We meten dan een te hoge $\mathrm{BMD}$.

De in onze studie gebruikte exclusiecriteria waren met name gericht op het uitsluiten van die degeneratieve afwijkingen en van botstofwisselingsbeinvloedende ziekten. Omdat het aantal vrouwen met een degeneratieve afwijking van de wervelkolom vee] groter is dan het aantal vrouwen met een stofwisselingsziekte ligt het voor de hand, dat de gemiddelde BMD van de subgroep met exclusiefactor hoger is dan de gemiddelde BMD in de subgroep zonder exclusiefactor. Gecorrigeerd voor de leettijd; bleek inderdaad dat het percentage vrouwen met osteoporose in de subgroep geëxcludeerden, hoger is dan in de totale studiepopulatie. De verschillen waren echter zo klein dat we hebben besloten, om voor het bepalen van de prevalentie van osteoporose, zoals beschreven hoofdstuk 3 , het bestand van geîncludeerden en geexchudeerden als een geheel te beschouwen. De verhouding 3500/703 is overigens arbitrair en werd bepaald door de maximale studieduur en de financièle draagkracht. Op grond hiervan berekenden we, dat $25 \%$ van de geexcludeerden voor onderzoek kon worden oproepen. 
De resultaten van de data-analyse gebruikt in hoofdstuk 5 lijken bovenstaand besluit ook achteraf te rechtwaardigen. Er blijkt namelijk een negatief, weliswaar niet significant, werband te bestaan tussen de aanwezigheid van ziekten en het voorkomen van osteoporose. Vervolgens werd echter aannemelijk gemaakt, dat niet artrose (als ziekte beschouwd) of aan artrose gerelateerde klachten (zoals rugklachten), maar de ziekten hypertensie en angina pectoris, verantwoordelijk zijn voor het minder frequent voorkomen van osteoporose onder de subgroep zieken. Hypertensie en angina pectoris zijn aandoeningen die sterk zijn gecorreleerd met obesitas, een belangrijke 'beschermer' tegen osteoporose (hoofdstuk 3). Zo deducerend staat hier, dat artrose mogelijk frequent gepaard gaat met obesitas en dus frequent gepaard gaat met hypertensie en angineuze klachten.

Recent verscheen er een artikel in de Lancet waarin op basis van een prospectieve studie werd betoogd, dat hypertensie juist gepaard gaat met een gemiddeld lagere $\mathrm{BMD}^{(\mathfrak{)})}$. Deze tegenstrijdigheid is met name toe te schrijven aan de selectie van de onderzochte populatie in de laatste studie. Het zijn niet de vrouwen met een hogere bloeddruk die een lager dan normale BMD hebben aan het einde van de studie periode van 4 jaar, maar het zijn de vrouwen met de laagste bloeddruk die na vier jaar een gemiddeld beter dan normale BMD hebben. Mogelijk omdat zij actiever zijn, meer wandelen, meer sporten, etc. Deze lifestyle variabelen werden in de studie niet genoemd. Overigens is de genoemde daling van de BMD ( $2 \%$ in 4 jaar) in de bloeddrukkwartielen 2,3 en 4 gelijk aan de te verwachten gemiddelde daling van $3-5 \%$ in $10 \mathrm{jaar}^{(4)}$.

Figuur 1 en 2 op pagina 109 tonen de prevalentie van osteoporose per leeftijdscategorie van 5 jaar. Boven de leeftijd van 65 jaar bleek de gemiddelde BMD in onze studiepopulatie niet verder af te nemen, terwijl het aantal osteoporotische vrouwen wel toeneemt. Een bevinding die ook uit De Rotterdam Studie en uit de studie van Steiger naar voren komt ${ }^{(5.5)}$. De per oplopende leeftijdscategorie toenemende SD van de gemiddelde BMD laat zien, dat het gemiddelde verschil tussen niet-osteoporotisch en osteoporotisch met de leeftijd toeneemt. Er moet dus een groep vrouwen zijn waarvan de BMD niet afneemt. De achtergrond kan zijn dat frequentie en omvang van de degeneratieve afwijkingen toenemen met de leeftijd. Een prospectieve studie waarin naast de BMD ook het ontstaan van degeneratieve afwijkingen wordt betrokken kan leren of deze conclusie juist is: Een gedeeltelijke verklaring voor de hierboven beschreven bevindingen werd overigens al gevonden in Hoofdstuk 7. In de subgroep van hen die èn door de huisarts zijn geïncludeerd èn van zichzelf aangeven niet bekend te zijn met een ziekte (de 'gezonden'), blijkt de gemiddelde BMD per oplopende leeftijdscategorie wel degelijk af te nemen (tabel 2 op pagina 108). Zowel De Rotterdam Studie, de studie van Steiger, als onze studie, bevatten een groot percentage 'zieken' en dat is de reden dat de gemiddelde BMD niet afneemt boven de leeftijd van 65 jaar. Het is de vraag hoe de selectieprocedures gewerkt hebben in bijvoorbeeld 
de studies van Riggs cs, die aantoonden dat de gemiddelde BMD met de leeftijd afneemt ${ }^{(n)}$. In dit verband kan worden opgemerkt dat het opvallend is, dat de gemiddelde BMI in onze studie en in De Rotterdam Studie ruim $27 \mathrm{~kg} / \mathrm{m}^{2}$ bedraagt, terwijl Amerikaanse onderzoekers met gelijksoortige onderzoekspopulaties bij herhaling een gemiddelde BMI vonden van circa $25 \mathrm{~kg} / \mathrm{m}^{2}{ }^{(8)}$. De bevolkingsstatistieken laten overigens voor de Noord Amerikaanse niet-negrolde bevolking wel een gemiddelde BMI zien van $27,3 \mathrm{~kg} / \mathrm{m}^{2}$ voor vrouwen van 65-74 jaar en dat getal ligt zelfs boven de gemiddelde BMI van 65-74 jarige Nederlandse vrouwen $^{(9)}$.

De resultaten van hoofdstuk 5 en van hoofdstuk 7 kunnen worden gecombineerd. In de grafieken 1, 2, 3 en 4 zijn de gecombineerde resultaten zichtbaar gemaakt. Het blijkt opnieuw dat leeftijd en gewicht de key predictors zijn voor osteoporose. De variabelen gezond en ziek, gewicht boven of onder de $70 \mathrm{~kg}$, hypertensie en rugklachten werden toegevoegd. In de hoogste leeftijdscategorie van elke subgroep blijkt dat het aanwezig zijn van rugklachten gepaard gaat met het iets minder vaak voorkomen van osteoporose, hetgeen past bij het meer voorkomen van degeneratieve afwijkingen van de wervelkolom op hoge leeftijd in relatie tot het voorkomen van rugklachten. Het effect van rugklachten op de BMD in de subgroep zieken wordt overigens ruimschoots overklast door het effect van hypertensie. 


\section{DE RELATIE TUSSEN LEEFTJD EN BMD}

in diverse subgroepen wan de totale populatie
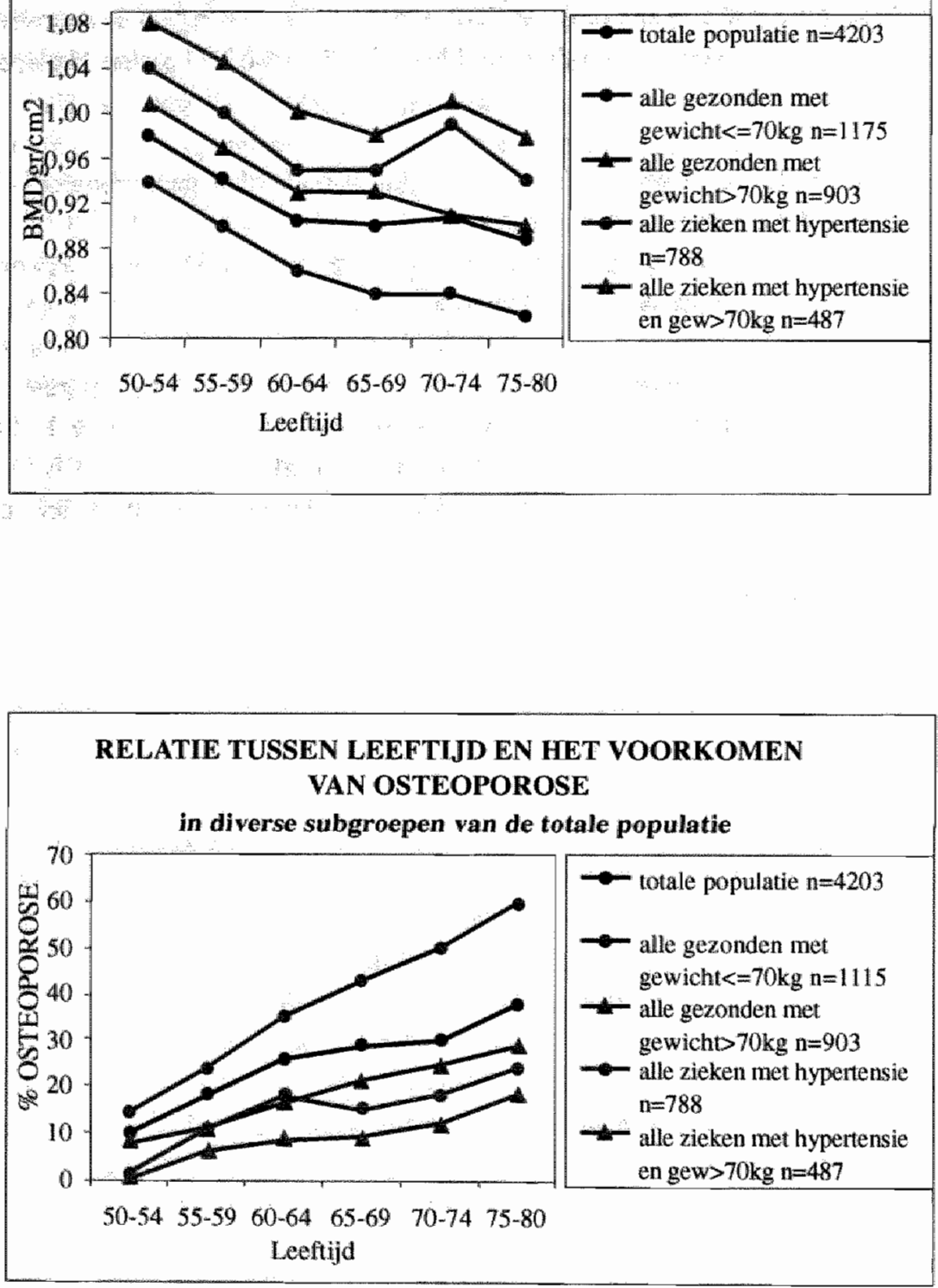


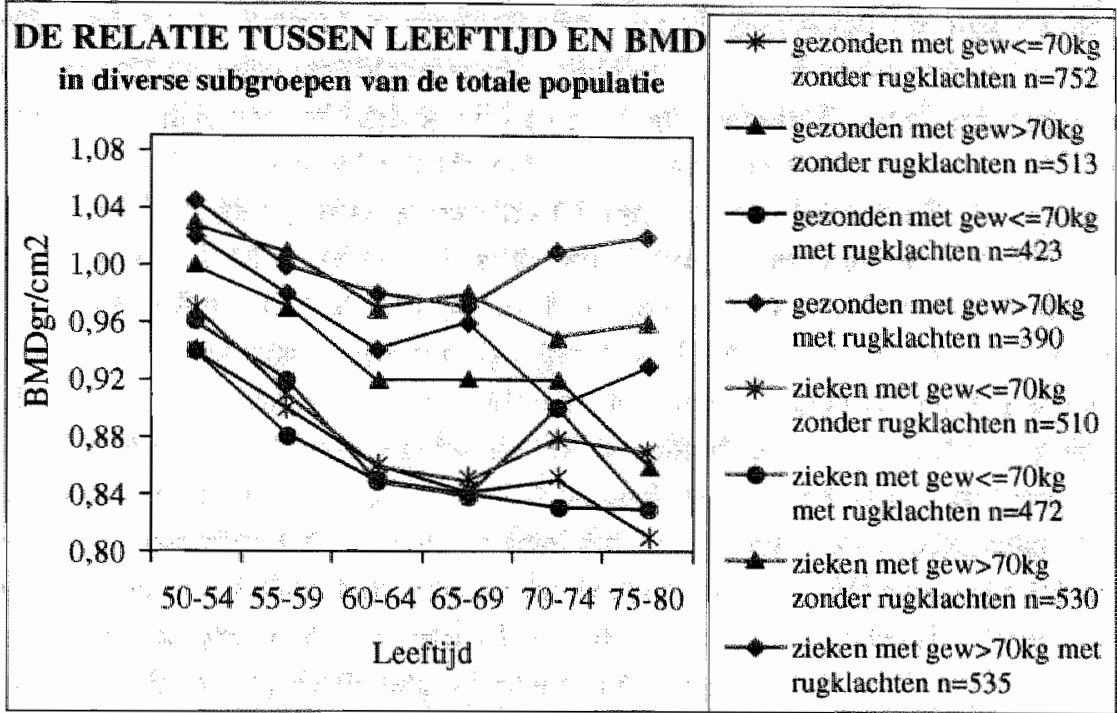

\section{DE RELATIE TUSSEN LEEFTIJD EN BMD in diverse subgroepen van de zieke populatie}

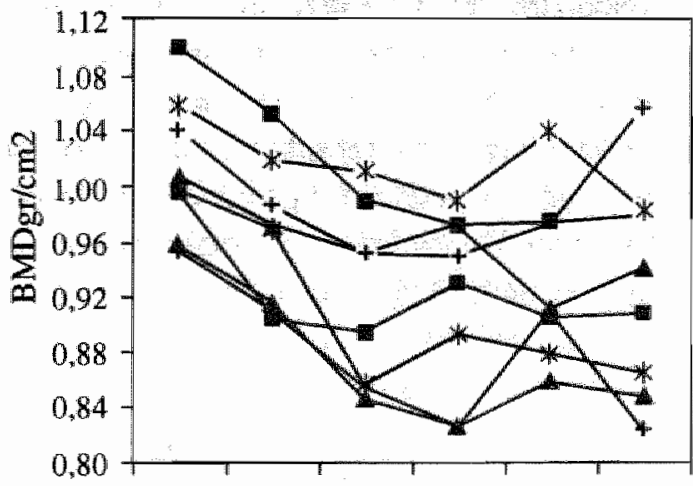

$\begin{array}{llllll}50-54 & 55-59 & 60-64 & 65-69 & 70-74 & 75-80\end{array}$ zieken gew<=70kg zonder hypertensie zonder rugklachten $n=338$

- zieken gew< $=70 \mathrm{~kg}$ zonder hypertensie met. rugklachiten $n=378$

- zieken gew $<=70 \mathrm{~kg}$ met hypertensie zonder rugklatchten $\mathrm{n}=172$

- zieken gew $<=70 \mathrm{~kg}$ met hypertensie met rugklachten $n=129$

-4-zieken gew> $70 \mathrm{~kg}$ zonder hypertensie zonder rugklachten $n=270$

$\rightarrow-$ zieken gew $>70 \mathrm{~kg}$ zonder hypertensie met. rugklachten $n=308$.

- - zieken gews 70kg met hypertensie zonder rugklachten $n=260$

Leeftijd 
De beantwoording van vraagstelling 2 (wat is de relatie tussen aan osteoporose gerelateerde klachten en/of verschijnselen enerzijds en de aan- of afwezigheid van de aandoening anderzijds) is aanmerkelijk complexer dan die van vraagstelling 1 . In hoofdstuk 3 blijkt dat leeftijd, BMI of gewicht, en het aanwezig zijn van een recente fractuur in onze studiepopulatie, de belangrijkste voorspellers zijn voor de aanwezigheid van osteoporose, terwijl de factor 'aanwezig zijn van ziekte' (niet-significant) lijkt te beschermen. Uit literatuuronderzoek blijkt dat er tal van ziekten worden aangemerkt als 'veroorzakers' van osteoporose (zie appendix E). Zo gesteld is er dus sprake van een tegenstrijdigheid tussen onze bevindingen (hoofdstuk 3) en de gegevens uit de literatuur. De oorzaak van de discrepantie moet met name worden gezocht in de selectie van de verschillende onderzoekspopulaties. Vele studies werden verricht in een 'klinische setting' met verwezen patienten of in studiepopulaties die werden samengesteld op basis van specifieke in- en exclusiecriteria (met de bedoeling het aantal confounders te verminderen). Een voorbeeld van dit laatste is het uitsluiten van patiënten met een fors overgewicht. Zoals blijkt uit table 7 op pagina 77 , heeft bijna $19 \%$ van de patienten in onze studiepopulatie hypertensie en is het overgrote deel van hen onder behandeling van de huisarts. Op grond van deze prevalentie van hypertensie in de eerste lijn en de eerder beschreven correlatie tussen hypertensie en overgewicht en de correlatie tussen overgewicht en de BMD, is het aannemelijk dat alleen al het selecteren op overgewicht of hypertensie tot grote verschillen in de prevalentie van osteoporose zal leiden in de diverse onderzoekspopulaties.

De waarde van biometrie als (hulp)middel bij screening op osteoporose wordt nader geanalyseerd in hoofdstuk 4 . Indien men de BMI wil berekenen, kan men even goed naar de lengte vragen als de lengte meten. De achtergrond daarvan is eenvoudig: patiènten geven frequent een te grote lengte op, dus is de berekende BMI relatief lager. Bij een vooraf afgesproken afkappunt van de BMI zullen er dus relatief meer osteoporotische vrouwen voorkomen in de groep onder dat afkappunt, c.q. worden er dus minder osteoporotische vrouwen tijdens een screening via BMI gemist. In de beschrijving van de resultaten zijn we in onze studie voorbij gegaan aan de waarde van de spanwijdte. Van circa 3000 vrouwen hebben we de spanwijdte wel gemeten. Ondanks alle inspanning konden we geen betrouwbare resultaten verkrijgen. Dit was de reden dat we vervolgens de spanwijdte niet meer hebben gemeten.

Al op jonge leeftijd blijkt de biometrie van belang in relatie tot de BMD, of liever de PBM. Magere kinderen hebben gemiddeld een lagere PBM dan corpulente kinderen ${ }^{(10)}$. Dit is een belangrijke bevinding want tal van onderzoekers toonden aan, dat de PBM voor een belangrijk deel (van 50-85\%) wordt bepaald door erfelijke factoren ${ }^{(11)}$. Erfelijkheidsonderzoek zou dus tenminste twee 'genenclusters' moeten kunnen aantonen: genen die bepalen hoe via hormonale of humorale regelmechanismen de botgroei en de botstofwisseling worden beïn- 
vloed en genen die bepalen hoe factoren via mechanische weg hun invloed op het bot uitoefenen. Gewicht, lengte en spierkracht (en spiermassa) zijn zichtbare en meetbare maten voor de mechanische factoren. De invloed hiervan op de PBM wordt geschat op 15-50\%. De effecten wan hormonale regelmechanismen, die tot de eerste groep kunnen behoren (geslachtshormonen, groeihormonen schildklierhormonen, vitamine D regulatoren, nog onbekende systemen? etc..) zijn echter minder goed zichtbaar en minder goed meetbaar. De interindividuele verschillen in de effecten van die regelmechanismen zijn zeer groot en verklaren ook de verschillen in de PBM niet. Het zoeken naar de verklaring voor de verschillen in PBM in relatie tot de hormonale status wordt ernstig bemoeilijkt door het feit dat we 'de conceptie' niet kennen. De vraag waarom of waartoe bot receptoren voor geslachtshormonen bevat, moet eerst beantwoord worden.

Vooropgesteld dat erfelijke factoren een belangrijke rol spelen, werd onlangs terecht de vraag gesteld, of wij in Nederland hebben kunnen aantonen dat osteoporose streeksgewijs verschillend voorkomt, hetgeen dan zou kunnen wijzen op de aanwezigheid van erfelijke invloed op de PBM. Tabel 8 op pagina 25 laat zien, dat de centra in Groningen en ZuidHolland laag scoorden: $32 \%$ van de vrouwen heeft een BMD van meer dan $2 \mathrm{SD}$ onder de norm. Het centrum in Groningen rekruteerde patiënten van het platteland, het centrum in Zuid-Holland rekruteerde patiènten uit de stad. Een groter contrast tussen de twee onderzoekspopulaties kunnen we ons haast niet voorstellen, want de populatie in de Randstad is veel minder bepaald door familieverbanden dan die van het Groningse platteland. Gezien de gelijke prevalentie van osteoporose in beide onderzoekspopulaties wordt erfelijke invloed op dit niveau (geografische spreiding) niet zichtbaar. Dat betekent overigens niet dat die factoren er niet zijn. Het multivariabele model Mens staat borg voor een adequate confounding. Op dit punt ontspint zich de discussie over de vraag of osteoporose een ziekte is of niet. De WHO definieert gezondheid als: een toestand van lichamelijk, emotioneel, psychisch en sociaal welbevinden en afwezigheid van ziekte. We zijn gezond, als we beschikken over de lichamelijke en geestelijke mogelijkheden om als mens in onze omgeving te bestaan (waarachtige zelfrealisatie). De osteoporotische mens is niet in staat zichzelf onder normale omstandigheden te handhaven; hij of zij zal onder normale condities immers een fractur op kunnen lopen. De angel in de vorige zin is het woordje 'kunnen', want zolang er geen fractuur is opgetreden weet noch de patiënt, noch de dokter, dat er met of in het lichaam iets mis is. De vergelijking met hypertensie en hypercholesterolaemie ligt voor de hand. Beide aandoeningen kenmerken zich door een langdurig beloop en een reêle kans op complicaties en onderscheiden zich in die zin niet van osteoporose.

In termen van de WHO luidt de definitie van ziekte: een schadelijke afwijking van de normale structuur of toestand van een organisme. Enstige osteoporose behoort derhall ve tot 
de ziekten. Ook met gebruikmaking van de WHO definitie is er nog enige discussie over de definitie van 'normaal. Het hanteren van een T-score of de Z-score, respectievelijk onder of boven een bepaalde leeftijd, is betrekkelijk arbitrair en roept dus vragen op. De antwoorden op deze vragen worden wellicht gevonden zodra betere beeldvormende diagnostiek zowel de structuur als samenstelling van het bot betrouwbaar kunnen bepalen ${ }^{(12)}$.

Orienterend literatuironderzoek levert op, dat er meer dan 90 factoren kunnen worden aangewezen als (mede) veroorzakers van osteoporose of osteoporotische fracturen. Osteoporose wordt hierbij vaak geduid als "secundaire osteoporose'. In appendix $E$ is dik gedrukt aangegeven, welke factoren in ons onderzoek zijn betrokken. Uit dit overzicht valt af te leiden dat osteoporose multifactorieel bepaald is. Ook de conclusie dat osteoporose geen specifieke oorzaak kent, wordt gerechtvaardigd, immers, osteoporose komt voor onder mensen bij wie geen van de genoemde factoren aanwezig zijn. Ons onderzoek in een steekproef, waarin het percentage geexcludeerden gelijk is aan het percentage geêxcludeerden uit de totale populatie, maakt aannemelijk, dat we in de dagelijkse huisartspraktijk nauwelijks rekening hoeven te houden met secundaire osteoporose maar veel meer met de biometrie van de patiènt (uitgezonderd bij patiênten die corticosteroïden gebruiken en bij patiènten die lijden aan een onbehandelde hyperthyreolidie). Het door ons gekozen afkappunt van $1 \%$ voor de prevalentie van co-morbiditeit variabelen in de gemiddelde huisartspraktijk, houdt in dat elke huisarts met een normpraktijk, met $95 \%$ zekerheid minstens 1 patient heeft met het betreffende kenmerk. Het gaat echter voorbij aan de wens dat we in de dagelijkse praktijk ook rekening moeten houden met bijzondere en weinig voorkomende ernstige ziekten (vooral die potentieel gepaard gaan met osteoporose). Dit laatste is echter slechts relevant als die bijzondere ziekte een solitair voorkomende ziekte is; dan heeft circa $25 \%$ van de zieken osteoporose versus $18 \%$ van hen die een niet-solitaire bijzondere ziekte hebben (Zie table $1 \mathrm{~b}$ op pagina 72 .). In table 7 op pagina 77 staan alle significante variabelen opgesomd en is de relevantie getoond van deze variabelen voor de huisartspraktijk. De laatste kolom in deze tabel toont ook hoe vaak het in de eerstelijn voorkomt, dat de patient in de tweedelijn onder behandeling is en wat de prevalentie is van osteoporose in de diverse subgroepen. Vanzelfsprekend zijn dit niet de prevalenties in de specialistenpraktijk. We merken op, dat deze resultaten gelden voor de patiëntenpopulatie van de gemiddelde huisartspraktijk. Zodra we een geselecteerde patiëntengroep bestuderen, bijvoorbeeld die in een specialistenpraktijk, gaat bovenstaande vergelijking niet op. Het percentage osteoporotische patienten is dan namelijk groter. In de praktijk van een longarts bijwoorbeeld, wordt de populatie vrouwelijke longpatiënten in de leeftijd van 50 tot 80 jaar gekenmerkt door een gemiddeld hogere leeftijd, een lagere BMI, en een grotere mate van immobiliteit.

Osteoporose is een surrogaat eindpunt van het proces van botontkalking. Het goed meetbare eindpunt is de fractuur. De fractururincidentie is echter van meerdere factoren (lichamelijke 
conditie, de mate van het bedrijven van sportieve activiteiten, de botstructuur etc.) afhankelijk ${ }^{(13)}$. De botstructuur en de BMD, samen de botkwaliteit, hangen evenzeer af van de biometrie-bepalende genetische factoren, als van de BMD alleen. De BMDonafhankelijke botstructuur blijkt gecorreleerd te zijn met de fractuurincidentie ${ }^{\left({ }^{(4)}\right)}$. Het lag voor de hand op grond hiervan na te gaan, hoe de onderzochte variabelen in hoofdstuk 3 onafhankelijk van de BMD zijn gerelateerd aan de incidentie van fracturen. De vraag, of het familiair voorkomen van osteoporose de verklaring is voor het familiair voorkomen van een verhoogd risico op fracturen, zou daarmee wat kumnen worden opgehelderd.

Goed beschouwd zijn er diverse factoren (zoals leeftijd, medische voorgeschiedenis, de aanwezigheid van ziekten, rookgedrag) waarvan de effecten op de BMD en de kans op een fractuur in belangrijke mate door de factor tijd worden bepaald, terwijl andere factoren (zoals alcoholgebruik) juist snel een effect kan sorteren. Inzicht in de onderlinge relatie tussen deze variabelen en het voorkomen van fracturen, werd in hoofdstuk 6 vergroot door analyses uit te voeren met die variabelen verdeeld in kwartielen. Zo laat hoofdstuk 6 zien dat tussen roken en het voorkomen van osteoporose of het voorkomen van fracturen geen direkt verband bestond (noch in de bivariate, noch in de multivariate logistische regressie analyse). Toch heeft roken invloed op het voorkomen van osteoporose, met name via de beinvloeding van het moment waarop de menopauze begint. Hoewel het intreden van de menopauze een zwakke voorspeller voor osteoporose is in hoofdstuk 3, laat de analyse na stratificatie (in hoofdstuk 7) van de totale populatie in subgroepen onder en boven de 65 jaar zien, dat een vroege menopauze een belangrijke voorspeller is voor osteoporose bij vrouwen jonger dan 65 jaar. Dit laatste geldt niet alleen omdat de leeftijd als voorspeller zoveel belangrijker is boven de 65 jaar, maar ook omdat er in de hoogste leeftijdscategorieen zoveel minder vrouwen zijn die vroeg in de menopauze kwamen. Rookten de ouderen minder, of zijn de rooksters eerder gestorven? Gaan rooksters eerder dood omdat ze vroeger in de menopauze komen?

Ook alcoholgebruik heeft een aparte plaats. Niet een gemiddeld hoog gebruik maar alcoholgebruik op zichzelf, voorspelt voor het aanwezig zijn van fracturen in de medische voorgeschiedenis. Veel vrouwen drinken 'zo nu en dan een glaasje'; met narne vaak in het weekend. De valkans en daardoor de kans op een fractuur wordt daarmee, met name op hogere leeftijd, vergroot. Dat vrouwen die vroeger aan sport deden op latere leeftijd frequenter iets breken verbaasde ons aanvankelijk wel. Sport is toch goed woor het handhaven van de BMD? Uit ons onderzoek echter bleek dat voor alle leeftijdscategorieên geldt dat sportsters gemiddeld enige kilos lichter zijn dan niet-sportsters (hoofdstuk 7) en dat de meeste vrouwen die aangeven aan sport te hebben gedaan en nog steeds doen, een weinig belastende sport beoefenen. 
De betekenis van de BMD op het vóórkomen van fracturen op hogere leeftijd is beperkt. Op theoretische gronden echter is de BMD, op elke leeftijd, een belangrijke voorspellende factor.

Osteoporotische fracturen komen vaker voor op plaatsen waar het bot een overwegend trabeculaire structuur heeft (heup, pols, wervel). In de totale studiepopulatie bleken vrouwen met een fractuur van de heup of pols inderdaad gemiddeld een lagere BMD te hebben dan zij, die een andere fractuur opliepen (respectievelijk $0,859 \mathrm{en} 0,890 \mathrm{gr} / \mathrm{cm}^{2}$ ). De kans dat er osteoporose aanwezig is, was in de groep vrouwen met een heup of pols fractuur $8 \%$ hoger, dan onder de vrouwen met een andere recente fractur. Het verschil is statistisch significant ( $\mathrm{OR}=1,4 \mathrm{CI}, 1,1-1,9)$. De volgende vraag is dan, wat in de eerstelijn de prospectieve betekenis is van een lage $\mathrm{BMD}$ op het ontwikkelen van een fractur. Het gevonden verband tussen de BMI vroeger, de BMI nu en de relatie met de BMD en de fractuurkans, illustreerde enerzijds het effect van de factor BMI zelf, anderzijds het effect van de tijd (tables 6a,b,c, pagina"s 94-96). Zo bleek, dat in de subgroep van vrouwen die op 25-jarige leeftijd een BMI hadden groter dan 25 en op latere leeftijd een BMI groter dan 30 (zij waren altijd relatief te dik) aanmerkelijk minder fracturen voorkwamen dan in de rest van de studiepopulatie (ook in de hoogste leeftijdscategorie). De kleine groep vrouwen die op latere leeftijd een lager gewicht heeft dan op 20-30 jarige leeftijd heeft een groter risico een fractuur op te lopen dan in de rest van de studiepopulatie. Niet het hebben van een ziekte maar het ontbreken van het beschermende vetweefsel is ook hier wellicht de verklaring.

In hoofdstuk 7 worden variabelen bestudeerd die typisch huisartsgeneeskundig kurnen worden gewaardeerd. Sportieve activiteiten en werkbelasting (met en zonder axiale belasting), opleidingsniveau en het hebben van kinderen worden bestudeerd in de subgroep gezonden (gezond achten wij die vrouwen die door de eigen huisarts zijn geïncludeerd en zelf aangeven niet aan een ziekte te lijden). De vraag 'bent u bekend met een ziekte' was een bewust globale vraag naar de gezondheidsstatus van de patiènte. Dat de patiënten met deze vraag goed wisten om te gaan, bleek bijvoorbeeld uit het feit dat alle patienten met een hoge bloeddruk (795) zijn terug te vinden in de subgroep 'zieken'. De vaststelling door de huisarts betekende dat de patiente voldeed aan de exclusiecriteria. In tegenstelling tot de analyses in de voorgaande hoofdstukken, zijn deze variabelen in twee leeftijdscategorieèn bestudeerd: onder en boven de 65 jaar. De achterliggende gedachte is dat naarmate de leeftijd vordert, de patiente vaak minder gezond is ('not healthy', zoals gebruikt in de flow chart op pagina 107), er steeds minder vrouwen zijn die werken en/of sporten en dat het aantal kinderen per vrouw groter is naarmate de leeftijd hoger is. Omdat de eerste twee factoren sterk afhankelijk zijn van het aanwezig zijn van een of meer ziekten, hebben we de analyse beperkt tot de subgroep gezonden. De resultaten van de multivariabele logistische regressie analyse in de twee leeftijdscategorièn hebben een nuancering opgeleverd van de eerdere 
bevindingen: onder de 65 jaar zijn er aanmerkelijk meer significante voorspellers voor osteoporose en voor een lage BMD dan boven de 65 jaar. Deze bevindingen kunnen van belang zijn bij het ontwikkelen van een preventieve strategie. Zo is sporten van belang voor een goede gezondheid en lichamelijk welzijn, maar het effect op de BMD valt tegen, zelfs als we specifiek kijken naar sporten met axiale belasting. De oorzaak moet niet te ver gezocht worden: het effect op de BMD van 'gewoon bewegen en huishouden doen' is weinig anders dan het effect van sporten op de BMD. Een veel groter verschil in effect op de BMD zal er zijn tussen immobiliteit en 'gewoon bewegen'. Een vergelijkbare verklaring zal gelden voor het geringe effect van het opleidingsniveau op de BMD (al of niet gecombineerd met werkbelasting of sport).

In de preventieve strategie past het advies dat men zo veel mogelijk zelf actief blijft in de dagelijkse bezigheden (eigen huishouding, zelf lopend boodschappen doen, wandelen). Bij onvermijdelijke immobiliteit past vanzelfsprekend dat er extra aandacht wordt gegeven aan valpreventie.

Wat is nu de oorzaak van osteoporose? Het antwoord is kort: een falen van de evolutie. De uitleg wordt iets langer. Voor zover ons duidelijk is uit de geschiedenis van de mens lijkt het er sterk op, dat de biologische ontwikkeling van de mens en de effecten van de verstandelijke ontwikkeling geen gelijke tred hielden. Zo weten we dat de huidige mens in wording eens op twee benen ging lopen. Die mens leerde rennen, kon beter de omgeving waarnemen, eerder inspelen op naderende gevaren, etc. Het leven was spannend en inspannend en beviel wel. Die mens leefde bij gratie van bewegen, was daartoe goed uitgerust en bereikte gemiddeld een respectabele leeftijd. Tot circa 8000 v.Chr. werd de vrouw gemiddeld 30 jaar en de man 35 jaar oud. Ze waren groot en gezond. Wat ook de oorzaak is, de verstandelijke ontwikkeling van de mens evolueerde snel en was mede aanleiding tot grootse veranderingen. De mens ging op stap; veroverde nieuwe werelden; vestigde zich in andere klimaatzones en bedacht methoden om zich, met minder lichamelijke inspanning, van alle gemakken, gezondheid en voedsel te voorzien. Nomadische stammen vestigden zich blijvend op vaste plaatsen. Aanvankelijk met als gevolg dat de gezondheidstoestand en gemiddelde levensverwachting (met name van de vrouw) toenamen. Later echter bleek, dat in de steeds grotere concentraties van mensen het aantal infectieziekten sterk toenam. De gezondheidstoestand ging achteruit en er trad een daling op van de gemiddelde lengte en levensverwachting ${ }^{(15)}$. Inmiddels is het tij gekeerd en geldt voor de West-Europese mens, dat deze 'moderne mens' vele jaren ouder wordt dan zijn voorganger. De winst aan jaren wordt doorgaans in rust gesleten en in deze extra jaren blijkt osteoporose steeds frequenter voor te komen. Op die rust is het lichaam dus niet goed voorbereid, noch hormonaal, noch biomechanisch. Daarmee is niet gezegd dat osteoporose het gevolg is van onvoldoende training en aanpassing in de zin van een gezonde leefstijl. De Brave New World moet niet te snel komen! 
Osteoporose was in de oude wereld een weinig frequent voorkomende aandoening omdat de levensverwachting van de vrouw in vrijwel alle (ontwikkelings)landen niet veel groter was dan het einde van de vruchtbare leeftijd. De kwaliteit van het bot is nooit ontkoppeld geraakt van de aanwezigheid van geslachtshormonen. Je zou kunnen zeggen dat het skelet tijdens de vruchtbare periode van de vrouw optimaal moet zijn en dat er daarom oestrogeenreceptoren in het bot aanwezig zijn; een soort zekerheidsstelling:

Of het zoeken naar de oorzaak van osteoporose zin heeft, zullen sommigen zich op grond van bovenstaande afvragen. De ontrafeling van de genetische code voor de ontstaanswijze van osteoporose zal immers eerder inzicht geven in de evolutie van de mens, dan in het ontstaan van osteoporose. Hier kan tegenin gebracht worden dat de vooruitzichten op een werkelijk effectieve preventie en behandeling, zonder dat inzicht niet groot kan zijn.

De beantwoording van vraagstelling 3 (welk diagnostisch advies kan er gegeven worden op grond van de bevindingen in de hoofdstukken $3 \mathrm{t} / \mathrm{m}$ 7) vindt in essentie plaats in hoofdstuk 3. De navolgende hoofdstukken zijn dieper gaande analyses van details uit hoofdstuk 3. In hoofdstuk 3 wordt aangegeven dat de populatie postmenopauzale vrouwen van 50 tot 80 jaar met het combineren van slechts drie factoren te verdelen is in subgroepen, die maximaal een factor 6 verschillen voor wat betreft de kans op de aanwezigheid van osteoporose. Een van die drie factoren is de BMI. In hoofdstuk 4 laten we zien dat de BMI niet gemeten hoeft te worden, maar dat het vragen naar gewicht en lengte volstaat. In hoofdstuk 5 blijkt, dat er, voor wat betreft de kans op het aanwezig zijn van osteoporose, drie co-morbiditeitsfactoren zijn waarmee de huisarts rekening moet houden: het gebruik van corticosteroiden (CS), de aanwezigheid van een maagoperatie in het verleden, en de aanwezigheid van nekklachten. Het langdurig gebruik van corticosteroïden per os veroorzaakt in een groot aantal gevallen osteoporose (op alle leeftijden en zowel bij zowel mannen als vrouwen). Meer dan $25 \%$ van de patiènten die langdurig corticosteroïden gebruiken lopen een fractuur op ${ }^{(17,18)}$. Het merendeel van deze patiênten is bij een specialist onder behandeling. Dat neemt niet weg dat we als huisarts de vinger aan de pols moeten houden. Langdurig gebruik van corticosteroilden vraagt om regelmatige controle van de BMD en preventie van osteoporose.

De betekenis van osteoporose voor het werk van de huisarts is moeilijk in maat en getal uit te drukken. De sterk toenemende incidentie van osteoporose (ten gevolge van de vergrijzing), en de voor de leeftijd gecorrigeerde toename van de incidentie van osteoporotische fracturen, bepalen dat de huisarts in de komende decennia steeds vaker met ernstige osteoporose in aanraking zal komen. De toegenomen en verbeterde diagnostiek zal daarnaast tot een groter aantal 'bekende osteoporose patiënten' leiden, op 
grond waarvan de huisarts dus frequenter om advies en preventieve maatregelen gevraagd zal worden. Een klein rekensommetje leert, dat de huisarts met een normpraktijk dagelijks met osteoporose te doen zal hebben als zijn osteoporotische patienten minimaal 1 tot 2 maal per jaar om advies vragen (een normpraktijk telt circa 100 vrouwen en 35 mannen met osteoporose: $135 \times 2$ consulten per jaar komt neer op meer dan 1 consult per werkdag).

De conclusies uit de diverse hoofdstukken levert het hierna beschreven advies op (een verfijning van het algoritme in hoofdstuk 3). Door het toekennen van een score aan het voorspellend vermogen van de diverse variabelen, kan een profiel worden samengesteld dat enigszins tegemoet komt aan de wens van Cadarette cs. Hij stelt de ontwikkeling van een screeningsmodel voor, dat niet alleen patiënten identificeert die voor verwijzing (DEXA) in aanmerking komen, maar dat tevens onnodige verwijzingen voorkom ${ }^{(16)}$. In dit profiel wordt gebruik gemaakt van leeftijd, al of niet aanwezig zijn van een recente fractuur, gewicht (i.p.v. de BMI, omdat er dan niet gerekend hoeft te worden en omdat er een goede correlatie is tussen BMI en gewicht) en de aanwezigheid van een vroege menopauze (i.p.v. het aantal vruchtbare jaren, omdat de vrouw het jaar van menopauze nauwkeuriger kan vermelden dan het jaar van de menarche).

Als voortzetting van het huidige cross-sectionele onderzoek wordt inmiddels een prospectieve cohortstudie uitgevoerd. De huldige studie vormt de basis van het ontwikkelde onderzoeksprogramma, dat tot doel heeft om de volgende vraagstellingen rondom osteoporose te onderzoeken:

1. Wat is de validiteit van het diagnostisch algoritme beschreven in dit proefschrift?

2. Wat is de prognostische waarde van de onderzochte determinanten voor osteoporose?

3. Wat is de diagnostische waarde van beeldvormend onderzoek anders dan in dit proefschrift beschreven (zoals ultrasound)?

4. Wat is de diagnostische waarde voor osteoporose van eenvoudig te bepalen botmarkers?

5. Wat is de relatie tussen spierkracht, coördinatie, botkwaliteit, valrisico en fracturen?

6. Welke zijn de genetische determinanten van osteoporose?

7. Hoe ontwikkelt de botdichtheid zich op de lange duur bij osteoporotische en nog niet osteoporotische vrouwen?

8. Wat is de relatie tussen het vóórkomen van osteoporose en osteoartrose? 
Tabel. Relatie tussen leeftijd, gewicht, recente fractur en vroege menopauze en het woorkomen van osteoporose. (percentages zijn afgerond op 5)

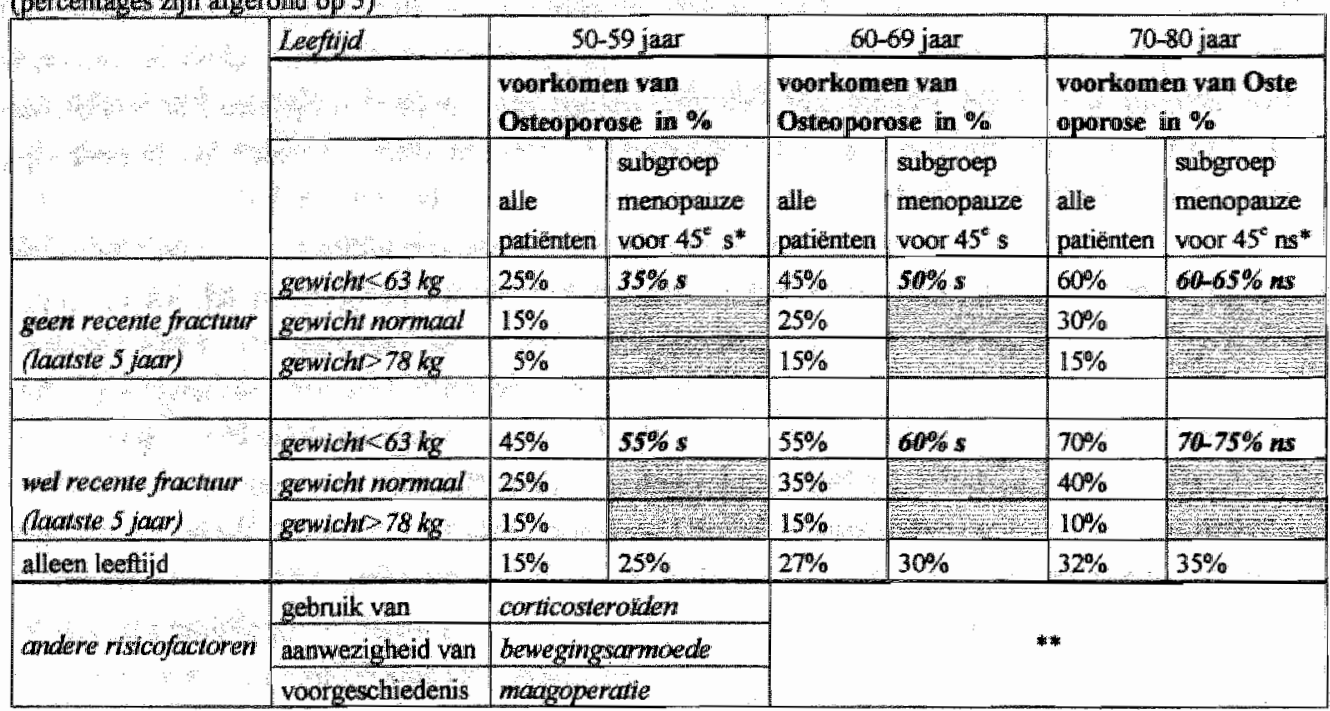

* $s=$ significant verschil tussen subgroep en alle patiënten, ns= niet significant verschil.

** Toelichting. De relatie tussen uroege menopauze en het voorkomen van astooporose blijkt in onze studie het zwakst in de subgroepen met een hogere leeftijd. De voorspellende waarde van de factor leeftijd voor het voorkomen van asteoporose neemt toe naarmate de leeftijd stijgt. Bij vrouwen met een gemiddeld of bovengemiddeld gewicht, is de relatie tussen een vroege menopauze en het voorkomen van osteoporose nog minder sterk. De gebruikte afkappunten voor het gewicht komen overeen met de kwartielen (Q1 en Q3); $25 \%$ van de vrouwen weegt minder dan $63 \mathrm{~kg}, 50 \%$ weegt $63-78 \mathrm{~kg}$ en $25 \%$ is zwaarder dan $78 \mathrm{~kg}$. Naarmate de leeftijd stijgt, neemt het percentage vrouwen dat recent iets gebroken heeft toe van circa $6 \%$ tot circa $14 \%$ (table 2 pagina 108). Fracturen komen met name voor in de categorie vrouwen met een gewicht lager dan $63 \mathrm{~kg}$. De uitzondering op deze regel is de categorie vrouwen van hoge leeftijd en en gewicht boven de $78 \mathrm{~kg}$ omdat deze wrouwen waker vallen.

Bewegingsarmoede (bedlegerigheid, immobiliteit en niet beweging als lifestyle) telt als een ernstige risicofactor voor osteoporose en (osteoporotische) fracturen. In onze studie echter met vrijwel uitsluitend ambulante vrouwen, konden we bowegingsarmoede echter niet mettem. Maagoperaties vinden tegenwoordig minder valk plaats dan vroeger. Malabsorptie, ten gevolge van magoperatie, als medeorzalak van osteoporose zal op den duur minder vaak voorkomen. 


\section{Referenties}

1. Bijl D, Grobbee DE. Het patient-controle-onderzoek. Gebu 1999;33:127-34.

2. Meunier PJ, Sellami $S$, Briancon D, Edouard $C$. Histological heterogeneity of apparently idiopatic osteoporosis. In: De Luca HF, Frost H, Jee W, Johnston C, Parfitt AM. Osteoporosis: recent advantages in pathogenesis and treatment. Baltimore: University Parc Press; 1981:293-301.

3. Cappucino FP, Meilahn E, Zmuda JM, Cauley JA. High blood pressure and bone-mineral loss in elderly women. The Lancet $1999 ; 354: 971-975$

4. Riis, BI. The role of bone loss. Am J Med 1995;98(suppl 2a): 29s-32s.

5. Burger H, Van Dale PLA, Algra D, Van den Ouweland FA, Grobbee DE, Hofman A, en al The association between age and bone mineral density in men and women aged 55 years and over: The Rotterdam Study. Bone Miner 1994,25:1-13.

6. Steiger PS, Cummings SR, Black DM, Spencer NE, Genant HK. Age related decrements in bone mineral density in women over 65. J Bone Miner Res 1992;7:625-32.

7. Riggs BL, Wahner HW, Seeman E, Offord KP, Dunn WL, Mazess RB, et al Changes in bone mineral density of the proximal femur and spine with aging. J Clin Invest 1982;70,716-723.

8. Flegal KM, Carroll MD, Kuczmarski RJ, Johnson CL. Overweight and obesity in the United States: prevalence and trends, 1960-1994. Int J Obes 1998:22:39-47.

9. Age and antropometric variables among Dutch elderly men and women Zeist Institute CIVOToxicologie, 1988 .

10. Boot AM, de Ridder MAI, Pols HAP, Krenning EP, de Muinck Keizer-Schrama SMPF. Bone mineral density in children and adolescents: relation to puberty, calcium intake and physical activity. I Clin Endocrinol Metab 1997;82:57-62.

11. Krall EA, Dawson-Hughes B Heritable and life-style determinants of bone mineral density I Bone Miner Res 1993,8.9.

12. Wasnich RD Consensus and the T-score fallacy, Clinical Rheumatology 1997,16(4),337-9.

13. Graafmans WC, Ooms ME, Hofstee HMA, Bezemer PD, Bouter LM, Lips P Falls in the elderly: a prospective study on risk factors and risk profiles. Am J Epidemiol 1996;143:1 129-36.

14. Allolio B. Risk factors for hip fracture not related to bone mass and their therapeutic implications. Osteoporosis Int 1999, suppl, 2 S9-S16.

15. A history of medicine, London: Simon and Schuster, 1992.

16. Cadarette SM, Jaglal SB, Murray TM. Validation of simple calculated osteoporosis risk estimation (SCORE) for patient selection for bone densitometry. Osteoporosis Int 1999; 10:85-90.

17. Laan RFJM, Riel PLCM Van, Putte LBA Van de, Eming LJThO Van, Hof MA Van 't, Lemmens JAM. Low-dose prednisone induces rapid reversible axial bone loss in patients with rheumatoid arthritis. Ann Intern Med 1993;1 19:963-68.

18. Lems WF, Jacobs JWG, Netelenbos JC, Dijkmans BAC, Bijlsma JWJ. Medicamentenze preventie van osteoporose bij gebruik van corticosteroïden. Ned Tijdschr Gieneeskd 1998; 142:1904-8 
Hoofdstuk 9

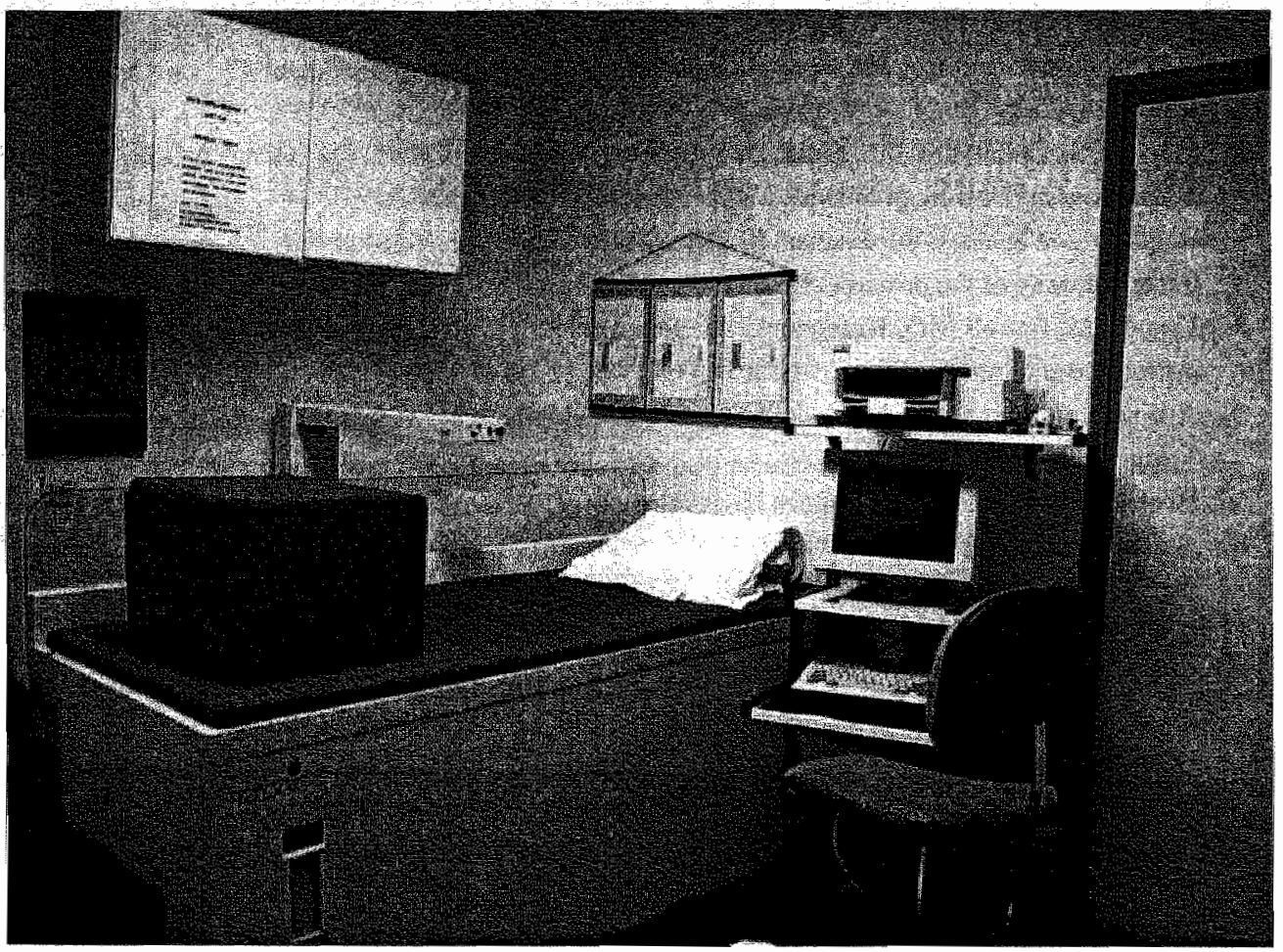




\section{Hoofdstuk 9}

\section{Samenvatting}

Dit proefschrift beschrijft de prevalentie en de diagnostiek van osteoporose onder 50 tot 80 jarige postmenopauzale vrouwen.

Hoofdstuk 1 is de algemene inleiding waarin kort wordt ingegaan op de gangbare definitie van osteoporose, op het feit dat er in de literaturur veel oorzaken van osteoporose worden genoemd en op het gegeven dat het moeilijk blijkt om, ook in Nederland, te komen tot een algemeen aanvaard plan van aanpak met betrekking tot diagnostiek en behandeling van osteoporose. Bevindingen uit klinisch (tweedelijns)onderzoek zijn niet zonder meer te extrapoleren naar de dagelijkse huisartspraktijk. De prevalentie van osteoporose in eerstelijns en tweedelijns populaties verschillen aanmerkelijk en diagnostische procedures kunnen ook daarom verschillen. Voor de diagnostiek van osteoporose heeft de huisarts een 'diagnostisch instrument' nodig, dat snel en eenvoudig in de dagelijkse praktijk is te gebruiken. Op basis van deze punten werden de volgende vraagstellingen geformuleerd:

1. Wat is de prevalentie van osteoporose onder de postmenopauzale vrouwen van 50 tot 80 jaar in de normpraktijk van de huisarts?

2. Wat is de relatie tussen aan osteoporose gerelateerde klachten, verschijnselen (fracturen, symptomen, biometrie en klinische bevindingen) enerzijds en het wel of niet aanwezig zijn van de aandoening anderzijds?

3. Welk diagnostisch advies (inclusief gerelateerde kosten) kan, op grond van de uitkomsten bij vraag 1 en 2, voor de dagelijkse huisartspraktijk worden opgesteld?

In hoofdstuk 1.2 wordt het studiedesign beschreven. Deze cross-sectionele, "populationbased' studie werd volledig uitgevoerd in de eerste lijn met medewerking van 23 huisartsen in 12 praktijken waarin total 9107 vrouwen van 50-80 jaar stonden ingeschreven. Van deze vrouwen voldeden er 5303 aan de inclusiecriteria (gehanteerd voor een therapeutische trial), bedoeld om een groep vrouwen te selecteren die met name niet lijdt aan aandoeningen die invloed op de botstofwisseling kunnen hebben. Deze vrouwen plus een aselecte steekproef van $943(25 \%)$ van de overige vrouwen werden opgeroepen voor deelname aan ons onderzoek. Van deze 6246 vrouwen gaven er 4725 gehoor aan de oproep, een opkomst van $75,6 \%$. Dit houdt in dat we van $52 \%(4725 / 9107)$ van alle vrouwen van 50-80 jaar, ingeschreven in de 12 huisartspraktijken, de botmineraaldichtheid (BMD) hebben kunnen meten. Het onderzoek werd gestart met een pilotstudie wan een maand. Gedurende die maand werden technische aspecten van de BMD metingen 
verbeterd, het studieprotocol aangescherpt en de patiëntenstroom naar (en van) het onderzoekscentrum geoptimaliseerd. Door middel van oefensessies werd aandacht besteed aan de kwaliteitscontrole van de metingen. De gegevens (meetgegevens en anamnestische gegevens) van alle vrouwen die na de pilotstudie werden onderzocht zijn geanalyseerd $(\mathrm{N}=4203)$

In hoofdstuk 2 worden de algemene resultaten beschreven. De opkomst bleek onafhankelijk van de afstand tot de huisartspraktijk waartoe de patiënten behoorden en het onderzoekscentrum Ook de aard van de, ziektekostenverzekering (ziekenfondsverzekerd of particulierverzekerd) had geen invloed op de opkomst. Met een gratis vervoersvoorziening en een soepele afspraakprocedure werd getracht de compliance te bevorderen. Een kleine groep non-responders (118) uit de praktijk van de onderzoeker kon nader worden beschouwd. Deze non-responders bleken zich voor wat betreft de leeftijd, het gewicht, de lengte, de BMI (body mass index) en de BMD, als groep niet te onderscheiden van de responders. De totale studiepopulatie werd verdeeld in twee groepen: wel of niet onder behandeling van hun huisarts of een specialist (de non-consulting patients', de 'GP-consulting patients' en de 'Specialist-consulting patients'). In de beschrijving van de totale studiepopulatie ('all patients') en de subgroep "consulting patients' bleek deze subgroep voor wat betreft de leeftijd iets te verschillen van de totale studiepopulatie. Dat ligt voor de hand omdat op latere leeftijd meer co-morbiditeit aanwezig is. De kans dat vrouwen in een hogere leeftijdscategorie werden uitgesloten op grond van exclusiecriteria was dus groter. In de subgroep 'consulting patients' valt op dat het percentage vrouwen dat langer dan 5 jaar de pil gebruikte veel groter is dan in de totale populatie. De overige variabelen komen in beide groepen bij benadering even vaak voor. De gemiddelde leeftijd van de studiepopulatie was 63 jaar; gemiddeld gewicht, lengte en BMI waren respectievelijk $71 \mathrm{~kg}, 161 \mathrm{~cm}$ en $27 \mathrm{~kg} / \mathrm{m}^{2}$ Deze waarden komen overeen met die van De Rotterdam Studie. De gemiddelde BMD van de lumbale wervelkolom (L2-L4) was $0,925 \mathrm{~g} / \mathrm{cm}^{2}$. Simultaan werden er in 6 centra in Nederland botdichtheidsmetingen verricht. Het percentage vrouwen in ons onderzoek met een BMD van minder dan 2 SD onder de norm ( $\mathrm{T}$-score) komt overeen (35,4\% versus $35,6 \%$ ) met het gemiddelde percentage van de 6 centra in Nederland.

In hoofdstuk 3 , wordt de studie beschreven die tot doel had een algoritme te maken om in de dagelijkse praktijk, patienten met osteoporose of een lage BMD (osteoporose plus osteopenie) snel en eenvoudig, te kunnen detecteren. De prevalentie van osteoporose en van een lage BMD werd bepaald aan de hand van de gemeten BMD van de lumbale wervelkolom $\left(\mathrm{L} 2-4\right.$, afkappunten $0,800 \mathrm{gr} / \mathrm{cm}^{2}$ voor osteoporose en $0,970 \mathrm{gr} / \mathrm{cm}^{2}$ voor een lage BMD). Vervolgens werd met behulp van 'multivariabele stepwise logistic regression analyses' berekend welke variabelen een statistisch significante correlatie 
vertoonden met de aanwezigheid van osteoporose en een lage BMD. De prevalentie van osteoporose was $23 \%$, die van een lage BMD was $65 \%$. Slechts drie variabelen (leeftijd, BMI en de aanwezigheid van een recente fractuur) waren statistisch significant en klinisch relevant gecorreleerd met de aanwezigheid van osteoporose en een lage BMD. Leeftijd (OR 2,70 voor osteoporose en OR 1,77 voor een lage BMD) en fracturen gedurende de laatste vijf jaar (OR 3,60 voor osteoporose en OR 2,85 voor een lage BMD) waren de belangrijkste voorspellers. Het algoritme toonde een absoluut risico voor osteoporose, van $9 \%$ tot $51 \%$ en een absoluut risico voor een lage $\mathrm{BMD}$, van $48 \%$ tot $84 \%$. De corresponderende relatieve risico's varieerden van 1,0 tot 5,7 en van 1,0 tot 1,8 . De conclusie dat, gebruikmakend van een algoritme met leeftijd, BMI en recente fracturen, subgroepen met een hoog risico voor osteoporose of een lage BMD op eenvoudige wijze kunnen worden geïdentificeerd. Op individueel niveau echter kunnen we, met welke combinatie van risicofactoren ook, veel vrouwen met osteoporose niet identificeren.

In hoofdstuk 4 wordt beschreven hoe subjectieve gegevens, zoals het door de patient herinnerde gewicht op 25-30 jarige leeftijd en haar lengte, gebruikt kunnen worden om de populatie - kostenbesparend - in te delen in subgroepen, die wel of niet in aanmerking komen voor screening op de aanwezigheid van osteoporose. Een vergelijking werd gemaakt tussen de diagnostische waarde (om osteoporose of een lage BMD vast te stellen) van de objectief gemeten BMI, de door de patiënt vermelde huidige (subjectieve) BMI en de BMI berekend op basis van het herinnerde gewicht op 25-30 jarige leeftijd en de opgegeven lengte (vroegere BMI). Bovendien werd bepaald hoeveel BMD metingen er met de drie verschillend bepaalde BMI's (de BMI-testen) nodig zijn om een osteoporotische patiënte of patiënte met osteopenie te ontdekken.

Voor de analyses gebruikten we een aselecte groep van 1155 vrouwen in de leeftijd van 50-80 waarvan we zowel de subjectieve lengte als hun gewicht op 25-30 jarige leeftijd kenden. Met behulp van ROC analyse werden de afkappunten bepaald voor de leeftijd en BMI (respectievelijk 60 jaar en $27 \mathrm{~kg} / \mathrm{m}^{2}$ ). De diagnostische waarden van de objectief gemeten BMI, de subjectieve BMI en de BMI op 25-30 jarige leeftijd werden bepaald aan de hand van voorspellende waarden (predictive value, PV) en odds ratios. De "terecht positieve' en 'terecht negatieve' voorspellende waarden werden gebruikt om te berekenen hoeveel BMD-bepalingen er verricht moeten worden om éen osteoporotische patiènte of één patiënte met osteopenie te vinden. Slechts de testen met de combinatie "leefijjd $\geq 60$ en BMI $\leq 27$ leverde PVs op voor osteoporose $(31 \%-41 \%)$ en voor een lage BMD (71\%-81\%) die hoger waren dan de vooraf kans voor deze condities. De betreffende odds ratios waren 2,14 - 3,18 (voor osteoporose) en 1,87 - 3,04 (voor een lage BMD). De objective BMI-test detecteerde $50 \%$ van de osteoporotische patiënten. Gebruikmakend van de subjectieve BMI-test en de vroegere BMI-test liep het percentage gedetecteerden op van $55 \%$ tot $69 \%$. 
De daarmee samenhangende kosten stegen per gevonden patient met $24 \%$. De detectie van patiënten met een lage BMD nam toe van $38 \%$ voor de objectieve BMI en $42 \%$ voor de subjectieve BMI tot $60 \%$ voor de wroegere BMI. De daarmee samenhangende kosten stegen met $11 \%$ Indien alle vrouwen boven de 50 jaar zouden worden verwezen voor een BMDbepaling zou het vinden van een osteoporotische patiente circa 304 Euro kosten. Het vinden van een patiente met osteopenie zou dan circa 116 Euro kosten.

We concluderen dat, indien er voor de detectie van osteoporose of een lage BMD gebruik gemaakt wordt van de BMI, het meten van het gewicht en het vragen naar de lengte volstaan. Ook al zijn leeftijd en BMI de sterkste risicofactoren voor osteoporose, om ze te gebruiken in een screeningsprogramma voor osteoporose zijn ze toch van te weinig waarde. Er is meer onderzoek nodig alvorens de leeftijd en de BMI kunnen worden gebruikt in screeningsprogramma's voor osteoporose.

In hoofdstuk 5 bespreken we de relatie tussen co-morbiditeit en osteoporose. Er wordt beschreven in welke mate co-morbiditeit kan worden gebruikt om osteoporose op het spoor te komen. De betekenis voor de huisarts wordt bepaald door de relatie te beschrijven tussen osteoporose en alleen die aandoeningen, die in voldoende mate in de huisartspraktijk voorkomen. Het gaat daarbij om ziekten waarvan met $95 \%$ zekerheid kan worden gezegd dat er tenminste één betreffende patiènt aanwezig is in een normatieve huisartspraktijk. Dit was de reden waarom we slechts die ziekten, klachten en medicaties in het onderzoek betrokken waarvan de prevalentie groter was dan $1 \%$. We gebruikten een aselecte steekproef van 1684 postmenopauzale vrouwen uit de totale populatie vrouwen van 50-80 jaar. Naast het gewicht, de lengte, de BMI en de BMD beschikten we over anamnestische gegevens over leefwijze, het vroegere gewicht en de vroegere lengte, de medische geschiedenis, de aanwezigheid van ziekten, klachten en het gebruik van medicatie. De grootte van deze steekproef werd bepaald door de verhouding 'geîncludeerden' (5303) en 'geexxcludeerden' (3804) in de totale populatie van 9107 vrouwen. Naast de 703 'geexcludeerden' selecteerden we aselect 981 vrouwen uit de groep van 3500 "geincludeerden' in onze studiepopulatie. Op deze wijze konden we de bevindingen extrapoleren naar de totale populatie. Alle analyses werden uitgevoerd voor de totale studiepopulatie en voor de subgroepen 'Non-consulting', 'GP-consulting' and 'Specialist-consulting' patienten. Naast bivariabele analyses werden multivariabele logistische regressieanalyses verricht met de BMD als afhankelijke variabele, en 48 variabelen met betrekking tot comorbiditeit plus 24 variabelen met betrekking tot de biometrie en leefwijze (het complete model als onathankelijke variabelen). Nadat was nagegaan of er van maskering sprake was werden de analyses herhaald met alle statistisch significante onafhankelijke variabelen uit het complete model (het gereduceerde 'final' model). Ten slotte maakten we een schatting van de klinische significantie van de resultaten door te berekenen hoeveel osteoporotische patienten konden worden gedetecteerd door gebruik te maken 
van de resultaten van het gereduceerde model. De verschillen in prevalentie van osteoporose en een lage BMD tussen de subgroepen met en zonder ziekten waren niet significant $(O R=1,13$ voor osteoporose; $O R=1,19$ voor een lage $B M D)$. Ook de verschillen in prevalentie van osteoporose en een lage BMD tussen de 'GP-consulting en 'Specialist-consulting' categorieen waren niet significant ( $O R=0,84$ voor osteoporose; $\mathrm{OR}=0,92$ voor een lage $\mathrm{BMD}$ ). De aanwezigheid van meer dan eẻn ziekte leek te zijn geassocieerd met een lagere prevalentie van osteoporose dan de aanwezigheid van éen ziekte; het verschil was echter niet significant $(O R=0,81$ voor osteoporose; $O R=0,85$ voor lage BMD). In alle categorieën ('Non-consulting, 'GP-consulting' en 'Specialistconsulting') bleken de subgroepen met de hoogste aantallen ziekten het laagste percentage vrouwen met osteoporose of een lage BMD te bevatten. Deze trend was consistent. maar niet statistisch significant. In de subgroepen van vrouwen met meer dan één ziekte met een prevalentie van meer dan $1 \%$ in een gemiddelde huisartspraktijk was de prevalentie van osteoporose significant lager dan de prevalentie van osteoporose in de totale studiepopulatie $(\mathrm{OR}=0,68)$. De prevalentie van osteoporose onder de vrouwen met een ziekte met een prevalentie onder de $1 \%$ was iets hoger dan de prevalentie van osteoporose onder alle zieke vrouwen $(\mathrm{OR}=1,41)$. Slechts zes co-morbiditeits variabelen vertoonden een statistisch significante correlatie met de aanwezigheid van osteoporose of een lage BMD. Positieve correlaties werden gevonden tussen het gebruik van corticosteroiden per os (CS) en osteoporose onder alle patiënten $(O R=4,2)$, tussen een maagoperatie in de voorgeschiedenis en osteoporose onder de 'GP-consulting' patiënten $(\mathrm{OR}=10,5)$ en tussen nekklachten en osteoporose onder de 'Non-consulting' patiènten $(\mathrm{OR}=3,4)$. Negatieve correlaties werden gevonden tussen nerveusiteit en een lage BMD onder de 'Non-consulting' patiënten ( $O R=0,3)$, tussen hypertensie en osteoporose onder alle patiënten $(O R=0,5)$ en tussen angina pectoris en osteoporose onder alle patienten $(\mathrm{OR}=0,5)$. Het gebruik van thiazide diuretica door patiênten met hypertensie of angina pectoris had geen significante invloed op de BMD. Een gemiddelde huisartspraktijk bevat 88 asteoporotische postmenopauzale vrouwen in de leeftijd van 50-80 jaar: 44 in de subgroep met één of meer dan eén ziekte en eveneens 44 in de subgroep zonder ziekte. De huisarts kent de medische geschiedenis van circa 228 postmenopauzale 'consulting' patiènten tussen de 50 en 80 jaar. Van deze patiènten zijn er 51 osteoporotisch: 26 in de subgroep 'GP-consulting' en 25 in de subgroep 'Specialist-consulting'. De subgroep 'Nonconsulting' ( $n=166$ ) bevat 36 'verborgen' osteoporotische patiènten. Derhalve zijn in de gemiddelde huisartspraktijk de meeste osteoporotische patienten als zodanig onbekend. We concluderen dan ook dat in de dagelijkse praktijk de klinische relevantie van comorbiditeit voor wat betreft de detectie van osteoporose of een lage BMD beperkt is. Comorbiditeit is wel belangrijk met betrekking tot de patièntenzorg maar is niet zinvol te gebruiken om de oudere vrouwelijke bevolking te screenen op de aanwezigheid van osteoporose. Of de incidentie van relevante klachten, ziekten, of het gebruik van medi- 
catie is te laag ò het percentage osteoporotische patiënten is te laag. Echter, alle patiennten die corticosteroiden gebruiken en alle patienten met een maagoperatie in de voorgeschiedenis moeten worden onderzocht op de aanwezigheid van osteoporose. Case-finding kan worden bevorderd door te vragen naar de aanwezigheid van nekklachten. Cardiovasculäire ziekten zijn vaak gerelateerd aan een relatief hoge BMD. Het zoeken naar osteoporose in deze categorie patienten is minder zinvol.

In hoofdstuk 6 laten we zien hoe de in hoofdstuk 3 genoemde risicofactoren voor osteoporose zich gedragen als risicofactoren voor het ontstaan van niet-traumatische fracturen. De analyses werden twee maal uitgevoerd: voor de totale studie populatie (4203) en voor de subgroep waarvan het gewicht op 25-30 jarige leeftijd bekend was (1155). Zowel de objectieve BMI als de geschatte BMI op jonge leeftijd (vroegere BMI) werden in de analyse betrokken. Fracturen (de afhankelijke variabele) werden onderverdeeld in: 1 . fracturen tijdens het leven; 2 . fracturen na het vijftigste levensjaar; 3 . fracturen die tijdens de laatste 5 jaar voor de BMD meting waren opgetreden.

De multivariabele stepwise backward and forward logistic regressie analyses, waarin de drie fractuurcategorieen als afhankelijke variabele werden gebruikt, werden uitgevoerd met alle beschikbare discrete en niet-discrete variabelen (die we bovendien verdeeld hadden in kwartielen). De relatie tussen het hebben van osteoporose en de aanwezigheid van fracturen werd gerelateerd aan de veranderingen in BMI (objectieve BMI versus recalled BMI). Hoge leeftijd, fracturen in de familie geschiedenis, en de BMD waren de sterkste voorspellers voor fracturen. De vroegere BMI was een statistisch significante voorspeller voor fracturen tijdens het leven en voor fracturen na het vijftigste Jevensjaar. Hysterectomie was geassocieerd met het vaker voorkomen van fracturen tijdens het leven. Perimenopauzale klachten in het verleden bleken geassocieerd te zijn met het minder voorkomen van fracturen na het vijftigste levensjaar. Gemiddelde (en zware) werkbelasting in het verleden was positief geassocieerd met de aanwezigheid van fracturen na het vijftigste levensjaar $(O R=1,9)$ en met fracturen tijdens de laatste 5 jaar $(\mathrm{OR}=2,8)$. Sportieve activiteiten in het verleden hadden een positieve associatie met de aanwezigheid van fracturen tijdens het leven en na het vijftigste levensjaar. Bivariabele analyses toonden aan dat vrouwen die roken niet significant meer fracturen hadden dan vrouwen die niet roken. Binnen de subgroep 'rooksters' bleek echter dat er significant meer fracturen voorkwamen bij de vrouwen die meer dan 35 jaar gerookt hadden. Roken was statistisch significant geassocieerd met vroege menopauze $(O R=1,4)$. Vroege menopauze was niet statistisch significant gerelateerd met de aanwezigheid van osteoporose, maar bleek wel statistisch significant gerelateerd te zijn met de aanwezigheid van fracturen in de leeftijdscategorieèn boven de 65 jaar (ORs 1,5, 1,9 en 1,8 respectievelijk). De absolute risico's voor het hebben van een of meer fracturen tijdens de afgelopen 5 jaar varieerden van $3 \%$ tot $28 \%$, voor een of meer fracturen na het 
vijftigste levensjaar van $4 \%$ tot $28 \%$ en voor een of meer fracturen tijdens het leven van $15 \%$ tot $44 \%$. Vrouwen in het laagste kwartiel van de vroegere BMI en objectieve BMI zijn vaak osteoporotisch $(40 \%)$. In deze categorie hadden vrouwen met een normalle BMD statistisch significant minder fracturen dan de categorie osteoporotische vrouwen. Vrouwen waarvan de BMI tijdens het leven lager werd zijn vaker osteoporotisch en vertonen meer fracturen tijdens de laatste 5 jaar dan verwacht $(O R=4,0)$. Vrouwen die (zeer waarschijnlijk) altijd relatief te dik zijn geweest waren minder vaak osteoporotisch en hadden een veel lager risico op fracturen.

We concluderen dat zowel een verlaagde als een verhoogde BMI zijn geassocieerd met een verhoogde kans op het ontwikkelen van fracturen op latere leeftijd. De fractuurpreventie bij te zware vrouwen moet gericht worden op de valfequentie, terwijl de fractuurpreventie bij slanke vrouwen de preventie en behandeling van een lage BMD vereist.

In hoofdstuk 7 wordt de relatie beschreven tussen sociale en sociaal-economische gegevens en het voorkomen van osteoporose. De vraagstelling luidde tot op welke hoogte de aan osteoporose gerelateerde sociaal-economische factoren de aanwezigheid van osteoporose kunnen voorspellen. De tweede doelstelling was vast te stellen in hoeverre deze factoren kunnen worden gebruikt bij de preventie van osteoporose bij gezonde postmenopauzale vrouwen met een leeftijd tussen 50 en 80 jaar, in de huisartsenpraktijk. De studiepopulatie bestond uit 2078 gezonde postmenopauzale vouwen in de leeftijd van 50-80 jaar. Als gezond definieerden wij die vrouwen, die door hun huisarts werden geincludeerd en vervolgens tijdens de enquêtering aangaven niet aan een ziekte te lijden: Gewicht, lengte en BMI van de vrouwen en de variabelen die mogelijk gerelateerd waren aan osteoporose, inclusief de sociaal-maatschappelijke factoren (sportbeoefening, beroep en opleidingsniveau, aantal kinderen en calciuminame (als maat voor kwaliteit van de voeding)) werden in verband gebracht met het vóorkomen van osteoporose. We voerden bivariabele analyses uit van de relatie tussen de sociaal-maatschappelijke factoren en de BMD in relatie tot de leeftijd. Alle analyses werden uitgevoerd met de totale studiepopulatie en met de subgroepen jonger en ouder dan 65 jaar.

We vinden dat in de leeftijdsgroep 'ouder dan 65 jaar' onder de gezonde vrouwen statistisch significant vaker osteoporose voorkomt dan onder de zieken $(\mathrm{OR}=1,8)$. Gezonde vrouwen hebben statistisch significant vaker een gewicht onder de $70 \mathrm{~kg}$ dan zieke vrouwen $(\mathrm{OR}=1,5) \mathrm{Er}$ werd geen consistente invloed aangetoond van de sociaal-maatschappelijke factoren op de BMD. Buiten de al eerder aangetoonde statistisch significante determinanten van de BMD bleken alleen de calciuminname, zware werkbelasting in het verleden en in het verleden uitgevoerde sportieve activiteiten met rugbelasting significant te zijn geassacieerd met de BMD. Dit gold overigens alleen voor de categorie 'jonger dan 65 jaar'. In alle leeftijdscategorieen verklaart het gewicht de verschillen in prevalentie van osteoporose in de subgraepen gezonde en zieke vrouwen. 
Conclusies. Het gegeven dat de leeftijd de meest consistente determinant is van de BMD suggereert dat osteoporose een typisch degeneratieve ziekte is. Deze associatie is duidelijker bij gezonde dan bij zieke vrouwen. In feite modificeert de factor gewicht het effect van de leeftijd op de BMD en laat zien dat osteoporose een actief proces is. Bij de preventie van osteoporose in de eerste lijn spelen sociaal-maatschappelijke factoren slechts een geringe rol. In tegenstelling met de bevindingen in hoofdstuk 3 (een studie die werd uitgevoerd onder een niet geselecteerde populatie) laat dit onderzoek (onder gezonde vrouwen) een lineair verband zien tussen de leeftijd en de BMD. In vele andere studies werd dezelfde relatie aangetoond. Op basis van onze bevindingen concluderen we dat die studies werden uitgevoerd onder voornamelijk gezonde patiënten (met een relatief laag gewicht) in een studiepopulatie met relatief weinig patiẻnten ouder dan 65 jaar.

In hoofdstuk 8 worden de belangrijkste resultaten besproken en wordt er kritisch gekeken naar de beantwoording van de vraagstellingen. Osteoporose komt zeer frequent voor onder postmenopauzale vrouwen. De meeste osteoporotische vrouwen kennen we als huisarts niet, omdat de aandoening vaker onder de gezonden dan onder de zieken voorkomt. Het verschil in prevalentie van osteoporose bij de gezonden en de zieken blijkt vooral te worden bepaald door het grote verschil in gemiddeld gewicht tussen deze twee categorieèn, met name boven de leeftijd van 65 jaar. Gezonde vrouwen in de leeftijdscategorie $75-80$ jaar zijn gemiddeld $10 \mathrm{~kg}$ lichter in gewicht en hebben daardoor frequenter osteoporose. De kans op de aanwezigheid van osteoporose blijkt niet of nauwelijks te worden beinvloed door sportieve activiteiten tijdens het leven, aard van het uitgeoefende beroep, het opleidings niveau of het al of niet hebben van kinderen. Onder de leeftijd van 65 jaar blijken de factoren BMI of gewicht en een vroege menopauze of het aantal vruchtbare jaren de kans op aanwezigheid van osteoporose te beinvloeden. Erfelijke factoren bepalen in belangrijke mate de te bereiken piekbotmassa (PBM). Primaire preventie van osteoporose heeft als doel het fractuurrisico te verlagen en moet dan ook beginnen in

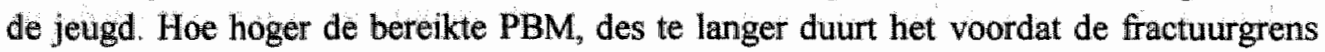
wordt bereikt. Het bereiken van een hogere PBM en het in standhouden van de BMD tijdens de premenopauzale periode, is vooral afhankelijk van het handhaven van een optimale lichamelijke conditie. Secundaire preventie, bijna per definitie aan de orde op de leeftijd boven de 50 jaar, is noodzakelijk ter voorkoming van grote schade (op individueel en op macro-economisch niveau) en start met het opsporen van de patiënt. De huisarts, die actief osteoporotische patienten wil opsporen, vindt na verwijzing voor een BMD meting, bij $25 \%$ van de hem consulterende patiënten $50 \%$ van de osteoporotische patiënten in zijn praktijk: Om de categorie van $25 \%$ te selecteren, hoeft de huisarts, rekening houdend met de leeftijd, slechts de BMI te meten (door te vragen naar gewicht en lengte) en te vragen naar een recente fractuur. Een klein aantal patiênten kan worden gevonden door alle gebruiker(ster)s van corticosteroiden, zowel per os als per inhalatie, 
in het diagnostisch plan te betrekken. Patienten met osteoporose hebben een groter risico om in hun leven een fractuur op te lopen. Hoe hoger de leeftijd, des te geringer de betekenis van de BMD voor het fractuurrisico. De BMI op jonge leeftijd voorspeit de BMI op latere leeftijd en heeft daarmee ook invloed op het fractuurrisico op latere leeftijd, enerzijds door middel van het effect op de BMD, anderzijds door de beschermende werking van de dikkere vetlaag zelf. Vroeger relatief te zwaar en op hoge leeftijd relatief mager; verhoogt het fractuurrisico aanmerkelijk. Altijd relatief te zwaar gaat gepaard met de laagste fractuurkans. Toch zit hier nog een addertje onder het gras: corpulente en toch actieve vrouwen lopen vaker een fractuur op dan corpulente inactieve vrouwen. De oorzaak daarvan moet gezocht worden in de valfrequentie. Preventie van fracturen moet dan ook verlopen via ten minste twee sporen: valpreventie in het algemeen en preventie en behandeling van osteoporose in de groep vrouwen met een relatief lage BMI.

Als voortzetting van het huidige cross-sectionele onderzoek wordt inmiddels een prospectieve cohortstudie uitgevoerd. De huidige studie vormt de basis van het ontwikkelde onderzoeksprogramma, dat tot doel heeft om de volgende vraagstellingen rondom osteoporose te onderzoeken:

1. Wat is de validiteit van het diagnostisch algoritme beschreven in dit proefschrift?

2. Wat is de prognostische waarde van de onderzochte determinanten voor osteoporose?

3. Wat is de diagnostische waarde van beeldvormend onderzoek anders dan in dit proefschrift beschreven (zoals ultrasound)?

4. Wat is de diagnostische waarde voor osteoporose van eenvoudig te bepalen botmarkers?

5. Wat is de relatie tussen spierkracht, coördinatie, botkwaliteit, valrisico en fracturen?

6. Welke zijn de genetische determinanten van osteoporose?

7. Hoe ontwikkelt de botdichtheid zich op de lange duur bij osteoporotische en nog niet osteoporotische vrouwen?

8. Wat is de relatie tussen het vóórkomen van osteoporose en osteoartrose? 


\subsection{Summary}

This thesis describes studies on the prevalence and diagnostic procedures of osteoporosis in postmenopausal women aged 50 to 80 in general practice.

Chapter 1 is a general introduction to this primary care-based study. It gives a brief outline of the currently accepted WHO-definition of osteoporosis, the question whether osteoporosis has a multi-factorial causality, and of the fact that there are, also in the Netherlands, many problems to be resolved before strategies on diagnostic management and the treatment of osteoporosis can be made. Findings from studies in specialized health care settings are not to be extrapolated to the primary health care setting as such, since there is a considerable difference between the prevalence of osteoporosis in primary and specialized health care settings. Correspondingly, one may expect that different diagnostic procedures are required in the two settings. In general practice the GP needs a quick and easy 'diagnostic instrument'. Based on the objectives described, we formulated the following questions:

1. What is the prevalence of osteoporosis in the population of postmenopausal women aged $50-80$ years, in general practice?

2. What is the relationship between the presence of osteoporosis and the presence of osteoporosis-related complaints and signs (clinical symptoms, fractures, biometrical variables) in postmenopausal women?

3. Which recommendations can be made to the general practitioner regarding detection of osteoporotic patients, based on the answers on the questions 1 and 2?

In chapter 1.2 the design and methods of the study are described. This cross-sectional, population based study was performed in a primary health care setting. 23 general practitioners (GP) in 12 GP-centres identified all 9107 women, aged 50-80, registered in their centres. Of the 9107 women identified 5303 healthy postmenopausal women were selected by the GPS. The criteria for being healthy were used to select patients for a concomitant therapeutic study and include those factors with known influence on bone metabolism. The 5303 women as well as every fourth woman (943) of the remaining group of 3804 patients were invited to participate in our study. Of the $6246(5303+943)$ women $4725(76 \%$ of the invited women, $52 \%$ of all women aged $50-80$ in the $12 \mathrm{GP}$ centres) were willing to participate. Written informed consent was obtained from all 4725 women. The women were questioned and examined (weight, height, body mass index (BMI) and bone mineral density (BMD) of the lumbar spine ( $L 2-\mathrm{L} 4$, measured using the Hologic QDR 1000). During the first month a pilot study was done. Only the data of those patients who entered the study after the pilot study were used for the statistical analysis $(\mathrm{N}=4203)$. 
In chapter 2 the general results of the study are described. The response rate tumed out to be independent of the distance between the patient's GP-centre and the research centre (investigators surgery). The response rate was also independent of the patient's health insurance (Public Health Fund (Sick Fund) and Private Health Insurance). With the help of a free transport service and a flexible arrangement to make an appointment in the research centre we tried to optimise the patient's compliance. A small number (19) of the non-responders on the registration list of the investigator (118) could be measured (during a consultation with their GP). This group of non-responders showed mean values of BMD, age, weight, height and BMI similar to those of the total population. The study population was divided into two subgroups: whether or not consulting their GP or a specialist (the 'non-consulting', 'GP-consuiting' and 'Specialist-consulting' patients). The mean age of the subgroup consulting patients was slightly lower than the mean age of the total study population, which could be expected because at older age co-morbidity is more frequent and therefore the number of excluded women will be higher. The percentage of women in this subgroup who used the pill for more than 5 years was much larger than in the total study population. All other variables were equally present in the subgroup consulting patients and in the total study population. The mean age was 63 years, mean weight $71 \mathrm{~kg}$, mean height $161 \mathrm{~cm}$ and mean BMI $27 \mathrm{~kg} / \mathrm{m}^{2}$. These values are similar to those from 'De Rotterdam Studie'. The mean value of the BMD was 0.925 $\mathrm{g} / \mathrm{cm}^{2}$ (SD 0.163). Simultaneously, BMD measurements were performed at 6 centres in The Netherlands. The percentage of women in our study with a value for BMD 2 SD or more below the young adult mean was equal $(35.4 \%$ versus $35.6 \%)$ to the mean percentage in the 6 centres.

In chapter 3 the objective is to construct a quick algorithm to detect patients with osteoporosis or low BMD and to determine its applicability in daily general practice.

The prevalence of osteoporosis and of low BMD was calculated by measuring the BMD of the lumbar spine (L2-L4, cut-off points at $0.800 \mathrm{~g} / \mathrm{cm}^{2}$ for osteoporosis and 0.970 $\mathrm{g} / \mathrm{cm}^{2}$ for low BMD). Multivariable, stepwise backward and forward logistic regression analyses' were performed with BMD as the dependent variable. An algorithm was constructed with those variables that correlated statistically significantly and clinically relevant with the presence of both osteoporosis and low BMD. The prevalence of osteoporosis was $23 \%$, that of low BMD was $65 \%$. Only three variables (age, BMI and fractures) were statistically significant and clinically relevant correlated with the presence of both osteoporosis and low BMD. Age (OR 2.70 for osteoporosis and OR 1.77 for low $\mathrm{BMD}$ ) and fractures during the past five years (OR 3.60 for osteoporosis and $\mathrm{OR} 2.85$ for low BMD) were found to be the key predictors. From the algorithm the absolute risks 
varied from $9 \%$ to $51 \%$ for osteoporosis and from $48 \%$ to $84 \%$ for low BMD. The corresponding relative risks varied from 1.0 to 5.7 and from 1.0 to 1.8 .

We concluded that using an algorithm with age, BMI and fracture history subgroups at high risk could be identified. However, in whatever combination, many women with osteoporosis could not be identified.

In chapter 4 the diagnostic accuracy of objectively measured; self-reported and recalled BMI for osteoporosis and osteopenia is described. We estimated the diagnostic costs, in terms of BMD measurements, per osteoporotic patient or low BMD patient detected, using different BMI tests.

1155 postmenopausal women aged 50 - 80 were asked for their present height and their weight at age 20-30. Subsequently their actual weight, height and BMD of the lumbar spine were measured. After ROC analysis, age was cut off at 60 years and BMI at $27 \mathrm{~kg} / \mathrm{m}^{2}$. Diagnostic accuracy of objectively measured, self-reported and recalled BMI were evaluated using predictive values (PV) and odds ratios. The resulting 'true positive' and 'false positive' rates were used to calculate diagnostic costs (i.e. BMD measurement) for each osteoporotic patient or low-BMD patient detected. The prevalence of osteoporosis in the study population was $25 \%$, that of low BMD $65 \%$. Only the age-BMI tests 'age $\geq 60$, BMI $\leq 27$ showed PVs for osteoporosis (31\%-41\%) and for low BMD (71\%-81\%) which were higher than the prior probabilities for these conditions. Related odds ratios were 2.14 3.18 (osteoporosis) and 1.87-3.04 (low BMD). The objective BMI test detected $50 \%$ of the osteoporotic patients. Using the self-reported BMI test and the recalled BMI test, detection rates increased to $55 \%$ and $69 \%$ respectively. Concomitant costs per osteoporotic patient detected rose by $24 \%$. Detection of patients with a low BMD increased from $38 \%$ for objective BMI and $42 \%$ for self-reported BMI to $60 \%$ for recalled BMI. Related costs increased by $11 \%$. In case all women over 50 years of age (irrespective of their BMT) were to be referred for BMD measurement, costs per osteoporotic patient or low-BMD patient detected would be 304 and 116 Euros respectively.

In conclusion: Only in women over 60 years does a BMI below $27 \mathrm{~kg} / \mathrm{m}^{2}$ provide a better prediction of the presence of osteoporosis or low BMD than could be expected solely on the basis of the relevant prevalences in postmenopausal women aged 50-80 years. If the use of $\mathrm{BMI}$ for the detection of osteoporotic or low-BMD patients is still considered, measuring weight and just asking for a person's height will do. Although age and BMI are the strongest risk factors for osteoporosis, they are of less significance when used for screening the population for osteoporosis. More research is needed before age and BMI can be included in any screening program.

Chapter 5 deals with the results of an analysis of the relationship between the presence of osteoporosis and the presence of osteoporosis-related risk factors, as well as diseases, 
disease-related complaints and pharmacological treatments (co-morbidity') in postmenopausal women. A random sample of 1684 postmenopausal women was drawn from all 9107 women aged $50-80$ years registered with the $23 \mathrm{GPs}$. The women were examined (weight, height, body mass index and BMD of the lumbar spine) and questioned on variables possibly related to osteoporosis (e.g. biometrical and life style data). In addition, all patients were questioned in detail on their medical history and the presence of any disease or health complaint and related pharmacological treatments. All statistical analyses were performed for the total study population and for the subgroups 'Nonconsulting, 'GP-consulting' and 'Specialist-consulting' patients. Cross table analyses were done to describe the relationship between the presence of one or more diseases and the presence of osteoporosis or low BMD. Multivariate stepwise backward and forward logistic regression analysis was done with 48 co-morbidity variables and 24 biometrical and lifestyle variables (complete model), using BMD as the dependent variable. After check-up for masking, analyses were repeated with all statistically significant independent variables found in the complete model (final model). Finally, we estimated the clinical significance of the results by calculating the number of osteoporotic patients that could be detected using the results of the final model. The differences in the prevalences of osteoporosis and low BMD between the subgroups with and without any disease were not statistically significant $(O R=1.13$ for osteoporosis; $O R=1.19$ for low BMD). Neither were the differences in the prevalences of osteoporosis and low BMD between the GP-consulting and Specialist-consulting categories $(\mathrm{OR}=0.84$ for osteoporosis; $O R=0.92$ for low $B M D$ ). Having more than one disease seemed to be associated with a lower prevalence of osteoporosis than having none or just one disease, though the difference was not statistically significant $(\mathrm{OR}=0.81$ for osteoporosis, $O R=0.85$ for low BMD). In all categories (Non-consulting, GP-consulting and Specialist-consulting) the subgroups with the highest numbers of diseases were found to include the lowest percentages of women with osteoporosis and low BMD. This trend was consistent but not statistically significant. Within the subgroups of women with more than one disease with a prevalence over $1 \%$ in an average general practice, the prevalences of osteoporosis were significantly lower than the overall prevalence for all women ( $O R=0.68$ ). The prevalence of osteoporosis in women with one disease with a prevalence below $1 \%$ was slightly higher than the overall prevalence for all diseased women (OR=1.41). Only six co-morbidity variables showed a statistically significant correlation with the presence of osteoporosis or low BMD. A positive correlation was found for the systemic use of corticosteroids (CS) ( $O R=4.2$ for osteoporosis in all patients), gastric surgery ( $O R=10.5$ for osteoporosis in GP-consulting patients) and cervical complaints ( $O R=3.4$ for osteoporosis in Non-consulting patients). A negative correlation was found for nervousness ( $\mathrm{OR}=0.3$ for low $\mathrm{BMD}$ in Non-consulting patients), hypertension ( $\mathrm{OR}=0.5$ for osteoporosis in all patients) and angina pectoris ( $\mathrm{OR}=0.5$; for osteoporosis in all 
patients). The use of thiazide diuretics by patients with hypertension or angina pectoris had no significant influence on BMD. The average general practice includes 88 osteoporotic postmenopausal women aged $50-80$ years, 44 in the subgroup with one or more diseases and also 44 in the subgroup without any disease. GPs will be familiar with the medical history of about 228 consulting patients. Of those patients 51 are osteoporotic; 26 in the subgroup GP-consulting, 25 in the subgroup Specialist-consulting. In the non-consulting subgroup ( $n=166) 36$ osteoporotic patients are 'hidden'. Hence, in an average general practice, most osteoporotic patients are unknown as such by the GP.

We concluded that the clinical relevance of co-morbidity for detecting osteoporosis or low BMD in daily general practice is limited. Co-morbidity is important with respect to patient care but useless in screening elderly female populations for the presence of osteoporosis. Either the incidence of relevant complaints, diseases and use of drugs or the percentages of osteoporotic patients are too low. However, all people using CS and all patients with a history of gastric surgery should be checked for the presence of low $\mathrm{BMD}$. Case-finding might be helped by asking consulting patients for the presence of cervical complaints: Cardiovascular disorders are often related to relatively high BMD. Therefore, searching for osteoporosis in this category is less useful.

In chapter 6 we described to what extent easily obtainable BMD-related risk factors are predictors of the occurrence of fractures and to what extent changes in these determinants during a patients lifetime are relevant.

In this cross-sectional population based study. We analysed the total population as well as a random sample of 1155 women for whom additional data were collected on recalled weight at age 20-30 and on self-reported height. BMI was estimated in two ways: 1. objective BMI $\left.[=\text { measured weight/(measured height })^{2}\right] ; 2$ recalled BMI [= recalled body weight at age 20-30/(self-reported height) $\left.{ }^{2}\right]$. Fractures (dependent variable) were categorized: 1. fractures sustained during the patient's lifetime; 2 . fractures after the age of 50; 3. fractures that had occurred during the 5 years before BMD measurement took place. Multivariate stepwise backward and forward logistic regression analyses, using fractures as the dependent variable, were performed with all discrete and non-discrete variables (divided into quartiles). The relationship between the presence of osteoporosis and the presence of fractures was related to the changes in BMI (recalled BMI versus objective BMI). More advanced age, a positive family history of fracture and BMD were independent key predictors of fractures. Low recalled BMI was a statistically significant predictor of fractures during the patient's lifetime and of fractures after the age of 50 . Hysterectomy was associated with a higher prevalence of fractures during the patient's lifetime. Perimenopausal complaints in history seemed to be associated with a lower prevalence of fractures after the age of 50 . Moderate (and heavy) occupational exercise in the past were associated with the presence of fractures after the age of 50 and fractures 
during the past 5 years. Sporting activities in the past showed a slight positive relationship with the presence of fractures during the patient's lifetime and fractures after the age of 50 . Bivariate analysis revealed that current smokers had not sustained significantly more fractures than current non-smokers, but within the subgroup of current smokers, the prevalence of fractures was significantly higher among those women who had smoked for more than 35 years. Smoking was statistically significant associated with early menopause. Early menopause was not statistically significant related to the presence of osteoporosis, but appeared to be statistically significant associated with the prevalence of fractures in the age categories over 65 years.

The absolute risks of sustaining one or more fractures ranged from $3 \%$ to $44 \%$. Women in the lowest quartile of recalled and objective BMI were often osteoporotic (40\%). In this category, women with normal BMD had a statistically significant lower fracture risk than osteoporotic women. Women with a possibly decreased BMI were most often osteoporotic and had sustained more fractures during past 5 years than expected. Women who had (probably) always been obese were less often osteoporotic and had a much lower fracture risk.

We concluded that decreased as well as increasing BMI are associated with higher risk of developing fractures at older age. Prevention of fractures in obese women must be concentrated on fall prevention, whereas prevention of fractures in lean women require prevention and treatment of low $\mathrm{BMD}$.

Chapter 7 presents the results of a cross-sectional study on the relationship between social and socio-economic factors and the presence of osteoporosis. The analyses were performed in a subgroup of healthy postmenopausal women aged 50-80. This study revealed that in the over 65 age categories, healthy women were statistically significant more often osteoporotic and had a lower weight than diseased women ( $O R=1.8$ for osteoporosis and $\mathrm{OR}=1.5$ for weight below $70 \mathrm{~kg}$ ). No consistent influence of social or socio-economic factors on BMD was found. Apart from the previously found statistically significant determinants of $\mathrm{BMD}$, only low calcium intake, heavy occupational exercise in the past and sporting activities 'with axial pressure' in the past, were found to be statistically significant related to BMD. However, this was only found in the category of women below the age of 65 . In all age categories, weight explained the different prevalences of osteoporosis in the categories of healthy and diseased women.

We concluded that age, being the most consistent determinant of $\mathrm{BMD}$, suggests that osteoporosis is a typically degenerative condition. The association between age and BMD is more evident in healthy than in diseased women. Weight modifies the effect of age on BMD, illustrating that osteoporosis certainly is an active process. Regarding osteoporosis prevention strategies in primary health care, the use of social and socio-economic factors in the management of osteoporosis would not be very helpful. In contrast with the 
findings of our previous study (performed in an unselected population), the present study (performed in healthy subjects) showed a linear age-related decrease in BMD. Many other studies have found the similar relationship. On the basis of our findings, we conclude that these studies were performed with rather healthy patients with a relatively low weight (and a relatively small number of patients over 65 ).

In Chapter 8, the main results of the present study are discussed in relation to our objectives. Osteoporosis is a common condition in postmenopausal women. In general practice, most osteoporotic women are not identified, consistent with our finding that osteoporosis is a disease that appears more often in non-diseased people than in diseased people. Therefore, osteoporosis is an idiopathic disease although there are factors that influence the course of the BMD during lifetime. The primary target of preventing osteoporosis is reducing the risk of fractures and should be started in one's early youth. The higher the peak bone mass (PBM), the longer it takes before the fracture-threshold is reached. The PBM is especially determined by hereditary factors. Achieving a higher PBM and maintaining the BMD during the pre-menopausal period depends on the maintenance of an optimal physical condition. Secondary prevention is necessary in preventing major damage on the individual and macro-economical level, and starts with tracing down the osteoporotic patients.

Taking age into account, the GP only has to measure the patient's BMI (by measuring the patient's weight and asking the patient's height) and be aware of the patient's most recent fracture, to be able to select a subgroup with high risk for osteoporosis. This subgroup (25\% of the women aged $50-80$ ) counts $50 \%$ of all osteoporotic women in a GP's practice. A small percentage of patients can be found by involving all users of corticosteroids (oral and by inhalation) in the diagnostic plan.Osteoporotic people have a greater fracture risk during lifetime. However, the older the patient the lower the relevance of the BMD in getting fractured. Someone's BMI at young age predicts the BMI at older age and therefore the risk of fractures, not only because the effect on BMD but also due to the protective mechanism of the soft tissue. Being obese at early age and skinny at older age increases the risk of fractures considerably. Always being obese goes hand in hand with the lowest risk of fractures. However, there is a catch in it somewhere: obese but active women have a greater risk of getting a fracture than inactive obese women. This is caused by the increased frequency of falling. Therefore, in the prevention of fractures we have to take into account: prevention of falling in general, and the prevention and treatment of osteoporosis in the category of lean women. 
As a continuation of the present cross-sectional study, a prospective cohort study is currently conducted.

Based on the results of our investigations we developed a research-program on osteoporosis. The main objectives in this program are covered by the following study questions.

1. What is the validity of the diagnostic algorithm described in this thesis?

2. What is the prognostic significance of the investigated determinants of osteoporosis?

3. What is the diagnostic significance for osteoporosis of imaging techniques other than described in this thesis (such as quantitative ultrasound measurements)?

4. What is the diagnostic significance for osteoporosis of easily measurable biochemical markers of bone turnover?

5. What is the relationship between muscle strength, co-ordination, bone quality ${ }_{s}$ fall risk and fracture incidence?

6. What are the genetic determinants of osteoporosis?

7. What is the long-term evolution of the BMD in osteoporotic and in non-osteoporotic women?

8. What is the relationship between the presence of osteoporosis and osteoarthritis? 


\section{Dankwoord}

Zonder patiènten geen onderzoek, en ze waren er: duizenden. De medewerking van hen bepaalde het welslagen van deze studie Graag wil ik hen bedanken.

De deelnemende huisartsen en hun praktijkassistentes zullen wel eens gezucht hebben onder de druk en drukte die wij veroorzaakten en toch bleven ze enthousiast hun zo belangrijke medewerking verlenen: P. van Aubel, M. Bemelmans, P. Blokland, F. Bolmers, R. Brouwers, H. Doesborgh, M. Eyck, F. Guldemond, A.Haas $†, M$. Hundscheid, W. van Kranen, R. Linden, W. Niessen, P.Passage, L. Peters, C. de Ploeg-Groenen, J. van de Ploeg, A. Schlösser, A. Sijstermans, J. Snijders, M. Weijts, F.A.P. Willemsen, M. Winten-Huisman. De belasting in de praktijk met Rob Brouwers was groot. Rob, het zal je zeker zorgen gebaard hebben; jouw tolerantie heb ik erg bewonderd. De praktijkassistentes werden omgetoverd tot researchassistentes en de researchasssistentes werden ook praktijkassistentes. Anouk Dibbets, de jongste, kreeg helemaal de zenuwen van mij (zo ver is Brussel toch niet weg?). Loes Stokkermans was van het eerste uur. Loes, we hebben samen heel wat opgestart, uniek. Kort na de start kwam Pauline Versteeg in beeld en vervolgens bleef ze daar, want heel Limburg kent haar nu: duizenden scans heeft ze gemaakt en hoe! De firma MIRAI, eigenaar van de DEXA-apparatuur, stond toe dat we de extra metingen kosteloos konden verrichten. Jacky Mertens en Biene Dupont waren de gezichten van de praktijk en ze hebben alles gezien! Zonder jullie consistente goeiigheid, organisatietalent en koffie waren we nergens. Ben ik iemand vergeten? Komt nog.

De ontwikkeling van het onderzoeksprotocol werd in gang gezet door Jan van Ree. De interesse voor het onderwerp was er eerder; in gang gezet door Wim Venekamp met de uitnodiging om samen informatieavonden over osteoporose te verzorgen. Daaraan hebben we veel plezier beleefd! Paul Höppener zat in de opstartfase van het project en zorgde met een grote grijns voor een berg literatuur. Kort na de definitieve start werd de projectgroep heel klein: twee. Geert-Jan Dinant werd dus mijn promotor. Voorop staat dat ik onze discussies en samenwerking als plezierig en erg stimulerend heb ervaren. Met het protocol, het uitgevoerde onderzoek en de projectgroep stond het researchtreintje op de rails. De bewerking van de date was een enorme klus maar Ad Veldt, de dBASE tovenaar, zorgde voor kloppende indexeringen, koppelde bestanden als drievoudige ritssluitingen en hielp het schonen van de data te versnellen. Paula Rinkens was de researchassistente voor dit deel van het onderzoek. Alle statistische analyses werden door haar bekritiseerd, verbeterd en uitgevoerd en we zijn goede maatjes geworden! Arnold Kester werd regelmatig bij de analyse betrokken, dank voor je uitleg en advies. Van analyse naar schrijven en publiceren is niet niks. In opstarten was Geert-Jan erg goed, in wegstrepen nog beter, maar het hielp. De kamer van Jan van Wersch bleek slechts een lage drempel te hebben: daarvan moet meer gebruik worden gemaakt! Engels en Nederlands, het had een nieuwe taalstrijd kunnen worden. 
De Engelse puntjes op de i werden gezet door Jan Klerkx en de Nederlandse puntjes door Catharina. Halverwege het laatste deel van het traject stapte Piet Geusens in. Hij bracht veel kennis en nieuwe impulsen mee en werd tweede promotor. Hij was graag bereid kritische kanttekeningen te maken. Cyril Schreurs, mijn opvolger, heeft er veel zin in. Met de student-assistenten (Shanti Brandon en Fleur de Bruijn) en de studenten (Francesca Thijssen en Liedewij Janssen) was het prettig werken. De secretaresses: Anouk Kerkhofs, Pascale Nelissen, Hannie Prick, Ine Siegelaer zorgden perfect voor de communicatie: per fax, e-mail, telefoon, post en te voet. De omslag van het boekje werd gemaakt door Rob Pronk, zijn computer maakte van mannetjes vrouwtjes, heel knap. Een groot deel van het onderzoek werd uitgevoerd 'onder eigen beheer'. Dat wil zeggen: er zat thuis iemand onder de enquêtelijsten en achter de toetsen (telefoon en PC) 1,5 miljoenl data veldjes werden gevuld. Honderden omissies in de databestanden werden gecorrigeerd, inconsistenties hersteld, desnoods werden patiënten even snel opgehaald om nog eens 'gemeten' te worden. Waar deed ze het voor? Ze wil niet op de omslag, moet toch wel veel van mij houden! Toos dus.

Medestanders en stimulanten dat waren het: Marjolein en Frank en Daniëlle. Prachtig.

28 juni 2000 ,

Danny 


\section{Curriculum vitae.}

Danny van der Voort werd geboren op woensdag 20 oktober 1948 om 06.30 uur te Lisse. Na behalen van het diploma HBS-B (1967) begon hij met de studie Geneeskunde aan de Universiteit te Leiden. Het doctoraal examen werd afgelegd in maart 1972 en het artsdiploma werd behaald in maart 1974. In dat jaar begon hij zijn loopbaan als huisarts in Hoensbroek. Huisartsopleider werd hij in 1983 (eerst PMOH, vanaf 1986 gecombineerd met de Beroepsopleiding). Naast het lidmaatschap van de planningsgroep PMOH werd hij docent 'automatisering van de huisartspraktijk" en docent "spoedgevallen in de huisartspraktijk'. Vanaf 1989 was hij ook huisartsonderzoeker voor klinisch geneesmiddelenonderzoek en vanaf 1990 voorzitter van een samenwerkingsgroep van huisartsonderzoekers (HORZL). In 1993 startte hij als 'extern onderzoeker van ExTra' te Maastricht het onderzoek met betrekking tot de diagnostiek van osteoporose. Met ingang van 1995 was hij frequent huisartsvoorzitter voor diverse nascholingscursussen voor huisartsen. Begin 1996 werd hij lid van de wetenschappelijke raad van de Osteoporose Stichting en in hetzelfde jaar werd hij redactielid van het Nederlands tijdschrift voor Osteoporose en andere Botziekten.

1 januari 1997 was een nieuw begin: de huisartspraktijk was aan de opvolger overgedragen en alle nevenactiviteiten werden gestaakt met uitzondering van zijn werk aan het osteoporose onderzoek en de bezigheden als huisartsvoorzitter. In het kader van het onderzoek volgde hij diverse cursussen en was hij spreker op congressen en nascholingsbijeenkomsten in Nederland.

Danny is getrouwd met Toos Duindam. Marjolein en Daniëlle zijn hun kinderen. 


\section{APPENDIX A. INCLUSIE- EN EXCLUSIECRITERIA}

Inclusie:

- Postmenopauzale vrouw van 50-80 jaar (postmenopauzaal wil zeggen dat de laatste menstruatie langer dan een jaar geleden is). Argumenten om voor deze categorie te kiezen: osteoporose komt voomamelijk postmeno-pauzal voor en boven de 80 jaar zijn veel vrouwen niet meer in staat zelfstandig naar het onderzoekscentrum te komen.

Exclusie:

- Ouder dan 50 jaar en nog niet postmenopauzaal.

- Vrouwen van het negroilde ras. Argument: bij negers komt osteoporose zelden voor.

- Vrouwen bekend met cen traumatische fractuur van de lumbale wervelkolom of met een substantiële scoliose. Argument: de te meten BMD is niet betrouwbaar.

- Vrouwen die behandeld worden met oestrogenen, corticosteroïden, androgenen, anabole

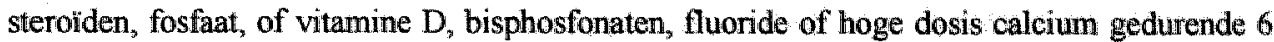
maanden voorafgaand aan de studie, calcitonine gedurende twee maanden voorafgaand aan de studie.

Argument: van deze middelen is aangetoond dat ze invloed hebben op de BMD:

- Vrouwen, die medicamenten gebruiken die invloed hebben op de botstofwisselling (thyroxine, insuline e.a.). Argument die medicamenten kunnen invloed hebben op het normale beloop van de BMD.

- Vrouwen met een invaliderende ziekte. Zoals ernstige neurologische ziekte, RA, e.a.. Argument deze vrouwen zijn vaak niet in staat naar het onderzoekscentrum te komen.

- Vrouwen die bekend zijn met secundaire osteoporose. Argument: de te meten botdichtheid wordt niet alleen bepaald door een nomaal verloop van de aandoening.

- Vrouwen die bij onderzoek een opvallend afwijkende lichaamsbouw vertonen. Argument: de oorzaak van de afwijkende lichaamsbouw kan het normale beloop van de botdichtheid beïnvloed hebben. De BMD meting kan onbetrouwbaar zijn.

- Vrouwen die verslaafd zijn aan alcohol of drugs. Argument: compl iance is vaak niet optimaal.

- Vrouwen die overgewoelig zijn voor bisphosfonaten of sulfapreparaten. Argument risico dat bij. deelname aan een van de trials, de aangeboden medicatie overgevoeligheidsreacties untlokt. 


\section{APPENDIX B. PROCEDURES}

\section{Medewerkers}

Voor aanyang van de studie werden de huisartsen woonachtig rondom het onderzoekscentrum (10 huisartsen) en 10 husartsen uit de omgeving uitgenodigd voor deelname aan de studie. Op een later tijdstip werd er nog een groepspraktijk (met 3 huisartsen) uitgenodigd om deel te nemen. De deelnemende huisartsen werden uitgenodigd op grond van het feit dat ze vertrouwd waren met de regels 'good clinical practice' door deelname aan eerdere studies.

Vraagstellingen en studieobject werden besproken, evenals de te leveren inspanning zoals het samenstellen van de patientenlijsten, het helpen bij corrigeren van onvolledige adressen of bij het zoeken van ontbrekende telefoonimummers. Hen werd verzocht aan patiẻnten met vragen over het onderzoek uitleg te geven. Alle deelnemende huisartsen stemden in met de voorgestelde aanpak van het onderzoek. De regio is te omschrijven als stad met verstedelijkt platteland en behoort tot de Oostelijke Mijnstreek, Limburg.

\section{Assistenten}

De praktijkassistenten in de 12 deelnemende huisartspraktijken werden geïnformeerd over doel en opzet van het onderzoek. Aan hen werd medewerking gevraagd bij het maken van de patiëntenlijsten en het opzoeken van slecht te vinden adressen en telefoonnummers. Het belang van de studie werd uiteengezet. Aangegeven werd hoe belangrijk een goede en zorgvuldige rekrutering is voor het welslagen van een studie en hoe groot de rol van de praktijkassistente daarbij is. De praktijkassistenten werden uitgenodigd om naar het onderzoekscentrum te komen om de DEXA-apparatuur te bekijken en eventueel hun eigen botdichtheid te laten meten. $\mathrm{Na}$ deze instructies was het voor hen niet moeilijk vragen van de patiënten omtrent het onderzoek te beantwoorden. Gedurende de periode dat de patiënten van een praktijk werden gemeten, was er dagelijks contact tussen het onderzoekscentrum en de desbetreffende praktijkassistentes.

De research nurses werden ingezet voor het bedienen van de DEXA., het verrichten van biometrie en het afnemen van de enquête en voedingsanamnese. Op grond van de geschatte werkbelasting en het gegeven dat de nurses elkaar moeten kunnen vervangen tijdens vakanties of ziekte werden vier research nurses partime aangesteld. De achtergrond van deze research nurses $(\mathrm{RN})$ was als volgt.

- RN 1: doktersassistente, met uitgebreide werkervaring als RN, cursus WP, training DEXA. werkt fulltime (ft) als $\mathrm{RN}$ (diverse trials).

- RN 2: doktersassistente, training DEXA, werkt 0,5 ft als RN en 0,5 ft als doktersassistente.

- RN 3: verpleegster, training DEXA, werkt 0,8 ft als RN.

- RN 4: Hbo-B (Biochemie), cursus. WP en cursus dBASE, training DEXA, werkt gedurende de studie fulltime als researchassistente. 
Voor aanvang van de studie volgden alle research nurses een, door de firma Hologic georganiseerde tweedaagse cursus. Geleerd werd de DEXA nauwkeurig en accuraat te bedienen en de gemeten gegevens te verwerken.

\section{Researchassistente}

Een van de research nurses kreeg de taak de gegevens in de computer in te voeren. Verder werd zij belast met het sigmaleren en oplossen van logistieke problemen en het bewaken van de onderzoeksprocedures. Met deze werkomschrjiving was ze de researchassistente "on the spot". De tweede researchassistente kwam in beeld op het moment dat de analyse van de data begon: zij zorgde voor alle statistische bewerkingen.

\section{Overige medewerkers}

Waartoe gerekend moet worden de computerdeskundige (ABASE programmeur), die de onderzoeker voorzag van programmatuur om de verzamelde data op snelle en handige wijze te coderen.

\section{Personeelsverloop}

Geen van de doktersassistenten of research nurses is tijdens de studie van baan veranderd of wegens ziekte uitgevallen.

\section{Procedures}

\section{Oproepen van de patiênten}

Alle oorspronkelijk geïncludeerde vrouwen ontvingen van hun huisarts een brief met uitleg over het onderzoek en een verzoek om deelname. De uitnodigingsbrief (zie appendix B) werd door de betreffende huisarts voorzien van eigen naam en logo. Korte tijd na ontwangst van de brief werd de patiènte door de eigen praktijkassistente gebeld. Eventueel werd een toelichting gegeven alvorens nogmaals om deelname werd gevraagd. Indien de patiente aangaf geinteres. seerd te zijn werd direct de afspraak voor de botdichtheidmeting gemaakt. De praktijkassistente werd daartoe door de researchassistente voorzien van blanco afsprakenlijsten waarop de voor meting beschikbare dagen en tijdstippen vooraf waren ingevuld. Indien een patiente niet telefonisch bereikbaar bleek stuurde de research nurse die patiente een kaartje met het verzoek het onderzoekscentrum te bellen.

Het oproepen van de patiënten die behoorden tot de steekproef (de aanvankelijk geexcludeerde vrouwen), nam en aanvang toen het meten van de geincludeerde vrouwen vrijwel was afgerond. De betrokken vrouwen werden door de research nurse gebeld. De informatie, vergelijkbaar met die in de uitnodigingsbrief, werd telefonisch verstrekt. Daama werd gevraagd of men aan het onderzoek wilde meedoen. Met de patiénten die wensten deel te nemen en zich in staat woelden naar het onderzoekscentrum te komen werd direct een afspraak gemaakt. Na het onderzoek kreeg de betrokken huisarts per fax bericht van het meetresultaat. 
Het in stand houden van de patientenstroom

In de aanvangsperiode (meting van de patiênten uit de praktijk van de onderzoeker, later genoemd de pilotstudy) werd bepaald hoeveel metingen er per dag konden worden gerealiseerd. Op grond van de overzichten die door de huilsartsen waren verstrekt, werd voor elke praktijk een schatting gemaakt van de tijd (weken, dagen) die nodig zou zijn voor de metingen Afhankelijk van het aantal patiënten per praktijk werden 3-5 reservedlagen ingelast alvorems te starten mel de metingen van de patienten van de volgende praktijk. De betrokken huisartsen en de praktijkassistentes werden ruim van tevoren geinformeerd over de geplande startdatum. Circa twee weken voor die datum makte de praktijkassistente een aanvang met het plannen van de agenda. De reservedagen werden gebruikt om de archivering bij te werken en om extra metingen te verrichten van patiënten die de afspraak hadden gemist.

\section{Compliance}

Voor patiènten die aangaven dat de afstand tussen woonadres en het onderzoekscentrum moeilijk was te overbruggen werd vervoer geregeld. Met name de patienten uit de steekproef kregen zo nodig vervoer aangeboden. Voor vervoer was een busje beschikbaar. De researchassistente regelde het vervoer: de patiënten werden, in groepjes van 3 of 4 personen, van het praktijkadres van de huisarts naar het onderzoekscentrum en terug gebracht. De praktijkassistentes in het onderzoekscentrum zorgden voor de ontvangst. Met deze aanpak werd bereikt dat van de gemaakte afspraken uiteindelijk slechts $2 \%$ niet werd nagekomen.

Het maken van de afspraken werd geregeld door de praktijkassistentes van de deelnemende huisartsen. Met de praktijkassistentes werd besproken hoe (soepel) het afsprakenboek gehanteerd moest worden. In het belang van het onderzoek moesten aan de patiênte voldoende mogelijkheden worden geboden, om een afspraak te kunnen maken op een tijd die de patiente schikte. Aan de praktijkassistentes werd verzocht om voldoende uitleg over het onderzoek te geven en zo de patiënten te motiveren aan het onderzoek deel te nemen. Het inschakelen van de praktijkassistentes was bedoeld om de opkomst te bevorderen.

\section{Metingen en meetinstrumenten}

\section{Procedure}

In het onderzoekscentrum kreeg de patiënte uitleg over de gang van zaken. Na ondertekening van het informed consent vulde ze een vragenlijst in (cie appendix C). Direct na het invullen werd de lijst door de research nurse gecontroleerd en zo nodig samen met de patiènte gecompleteerd. Vervolgens werd de voedingsanamnese door de research nurse afgenomen. Gewicht, lengte en spanwijdte werden bepaald en tenslotte de botdichtheid gemeten. Bij deze activiteiten waren steeds twee research nurses betrokken. De botdichtheidmeting nam gemiddeld 10-15 minuten in beslag. De patiente neemt, normaal gekleed (zonder metalen delen in het scangebied), plaats op de DEXA-onderzoekbank. De researchnurse positioneert de patiènte met behulp van een laserlampje en zet de computergestuurde meetprocedure ingang. De resultaten werden direct na meting geprint. De patiēnten werden geïnformeerd naar behoefte, hetgeen wil 
zeggen dat uttleg over de meetresultaten werd gegeven indien de patiente dit wenste De huisartsen ontvingen dezelfde dag per fax de scangegevens van hun patienten

\section{Onderzoeksnumte en DEXA}

Voor het onderzoek werd gebruik gemaakt van de ter beschikking staande in het onderzoekscentrum geplaatste, DEXA (dual energy X-ray absorptiometry). De werking van de DEXA is op het volgende principe gebaseerd. De röntgenbuis produceent fotonenbundels van twee verschillende energieniveaus. De bundels worden verzwakt door het te meten object. De mate van verzwakking is athankelijk van het soort objeet (zoals bot en bindweefsel) en van het energieniveau van de bundel. Door dit verschil in verzwakking van de beide fotonenbundels kan bot van bindweefsel worden onderscheiden en de BMD, onafhankelijk van de hoeveelheid bindweefsel, worden berekend.

Voor de plaatsing van de DEXA moest een der onderzoekkamers van het onderzoekscentrum worden 'aangepast'. Bijvoorbeeld het blinderen en isoleren van een tussenmur ter voorkoming van geluidsoverlast. Eerdere inventaris werd verwijderd Nieuwe kasten, computertafel e.d. wer. den op maat gemaakt en geplaatst. Een nieuwe weegschaal, alleen te gebruiken voor het onderzoek, werd aangeschaft. Op de geblindeerde muir werd een matrix met centimeterverdeling aangebracht om lengte en spanwijdte te meten. Tenslotte werd er een aparte telefoonlijn voor fax/telefoon aangelegd Op pagina 132 een foto van de onderzoekkamer in de praktijk.

\section{Uitvoering van de metingen}

Alle BMD-metingen werden verricht met de Hologic QDR 1000 (Hologic Europe, Brussel). Elke ochtend voor aanvang van de metingen vond er een ijking plaats met behulp van een fantoom. De ijkgegevens werden vergeleken met de oorspronkelijke ijk-waarden (uitgangswaarden) van het fantoom. Indien er verschuiving optrad ten opzichte van die uitgangswaarden werd de apparatuur door de lewerancier bijgesteld. Het gewicht van de patient werd steeds bepaald met dezelfde weegschaal en ook die werd regelmatig geijkt De patient werd gewogen zonder jas en zonder schoenen. De meting van de lengte vond plats zonder schoenen, met de rug en hielen tegen de muar. Voor het bepalen van de spanwijdte werd de patiênte verzocht de armen maximaal zijwaarts te strekken. Lengte en spanwijdte werden op de matrix afgelezen. De door de patiênte ingevulde enquêtelijst werd door de research nurse gecontroleerd en zo nodig samen met de patiente gecompleteerd. Ook werd zo nodig gebruik gemaakt van informatie van aanwezige familieleden van de patiente. De voedingsanamnese werd verricht door de research nurse.

\section{Kwaliteitscontrole van de metingen}

De controle op de technische aspecten van de BMD metingen (positionering, witlijnen en berekeningen) vond plaats door externe deskundigen aan de hand van de geprinte scanresultaten en de meegeleverde scanimages op floppy disk. Gesignaleerde fouten werden hersteld, soms door de patiênte opnieuw op te roepen en nogmaals te meten. Problemen die reeds tijdens de meetprocedure werden gesignaleerd (positionering, uitlijning, bijzondere bevindingen) werden 
direct met de onderzoeker besproken en opgelost. De vier research nurses zorgden voor een goede afstemming op elkaar door het samen bespreken van bijzondere ervaringen of bevindingen.

Teneinde op betrowwbare wijze de vagenlijsten te kumen laten afnemen en de ingevulde enquettes goed te kunnen beoordelen en aan te vullen, werden in het bijzijn van de onderzoeker oefentessies gehouden. $\mathrm{Bij}$ de aanvang van de studie twee mall, na een week een maal en halkerwege de studie (toen de vierde research nurse in beeld kwam) nog twee maal. Met name voor de voedingsanamnese bleek dat het afnemen van een standaardvragenlijst niet altijd tot de juiste uitkomsten leidde. Patienten interpreteerden de vragen op een verschillende manier. Een voorbeeld maakt duidelijk hoe verschillend dezelfde vraag kan worden opgevat, maar ook hoe verschillend een concreet antwoord op een vraag kan worden opgevat. Op de vraag drinkt u melk', antwoordit een patiènte: 'nee'. Op de vraag 'drinkt u de koffie met melk', antwoordt dezelfde patiènte met: "ja, ongeveer een halve liter melk per dag". Een andere patiênte zal op dezelfde vraag antwoorden 'ja, ik drink melk in de koffie'. Op de vraag 'eet u wel eens harde kaas", volgt soms het antwoord: ja, twee plakjes per dag'. Noch de patiente, noch de onderzoeker heeft enig idee van het gewicht van die plakjes. Dat wordt pas duidelijk na de vraag thoeveel kaas koopt u per week en hoeveel eet u daarvan zelf op'. Het antwoord is soms heel precies: ik koop elke week een kilo en de helf eet ik zelf op; op het brood en soms 's avonds' een paar stukjes": De hoeveelheid kaas per dag, berekend na het tweede antwoord is tweemaal zo groot als berekend na het eerste antwoord: De calciuminname werd steeds door dezelfde research nurse berekend.

\section{Datamanagement}

\section{Gegevensregistratie en kwaliteitscontrole}

De verzameide data bevonden zich aanvankelijk in meerdere bestanden:

- de scangegevens werden opgeslagen in een ABASE TV-file van de DEXA-computer.

- de overige patièitgegevens zoals gewicht, lengte, geboortedatum en berekende calciunninname werden opgeslagen in een tweede dBASE TV-file van de DEXA-computer,

- de enquetegegevens werden separaat in een derde dBASE IV-file ingevoerd.

Na indexering van de drie bestanden werden deze tot eén bestand gekoppeld. Na koppeling bleek $95 \%$ van het nieuwe bestand de correcte combinaties van de drie oorspronkelijke files te bevatten. De $5 \%$ foute combinaties werden gecorrigeerd door handmatige' vergelijkíng van geboortedata, initialen en scanuitslagen. De fouten bleken met name te berusten op het voorkomen van dezelfde geboortedata en dezelfde initialen. We vonden tweemaal dezelfde geboortedatum met dezelfde initialen en dezelfde huisarts. De ongelijke scangegevens waren correct genoteerd want deze 'misser' werd veroorzaakt door het feit dat een tweeling met een tweeling was gehuwd. Uiteindelijk bleek $0,11 \%(\mathrm{n}=5)$ van beide data files niet met elkaar in overeenstemming gebracht te kunnen worden De betreffende patiênten werden uit het bestand verwijderd. 
Omwille van een optimale betrouwbaarheid werd het overbrengen van de gegevens op de enquêteformulieren naar bestanden in de computer altijd door dezelfde assistente gedaan. De data werden geschoond van typefouten en onmogelijke combinaties. Voorbeeld: een patiente geeft aan een te snelle schildklierwerking te hebben en in het medicatieveld staat Thyrax. Dit was een reden om het enquêteformulier nog eens te raadplegen of om de patiente telefonisch om verheldering te vragen. Het was niet goed mogelijk om de benodigde tijd voor dit proces van opschonen tevoren te berekenen. Nadat gebleken was dat de eerste ronde bijna twee weken duurde werd in het werkplan maandelijks een dag gereserveerd om het bestand op fouten te controlleren.

\section{Codering van de gegevens}

Een tweefasen plan werd ontwikkeld en uitgevoerd in de maanden januari en februari 1995. De eerste fase hield in dat alle door de patiênten geleverde informatie, die letterlijk van de enquêtes was overgenomen, tot uniforme eenduidige informatie werd ongezet. Zo werden hoge bloeddrik, verhoogde bloeddruk, en te hoge bloeddruk genoteerd als 'RR+ De tweede fase bestond uit het coderen van de geüniformeerde gegevens. Voor het coderen van aandoeningen en ziekten werd gebruik gemaakt van de Short Titles van de International Classification of Primary Care ( ICPC) ${ }^{(21)}$ Het coderen in ICPC codes werd gedaan met behulp van een voor dit onderzoek geschreven dBASE IV hulpprogramma. Voor de codering yan sociale laag en beroepshalve lichamelijke inspanning werd gebruik gemaakt van de Beroepenklapper van het Instituut voor Toegepaste Sociale Wetenschappen. Sportieve activiteiten werden gecodeerd in drie categorieèn. 


\section{ARPENDXX C. INFORMATE YOOR PATLENTEN DIR DEELNEMEN AAN DE .. STUDIES}

Varr uw hivisarts heeft u te horen gekregen dat w tot de patientengroep behoort die hetzij osteoporose (botontkalking) hebben hetzij het risico lopen on ositeoporose te ontwikkellen.

Her is algemeen bekend dat vrouwen boven de 50 jaar, die geen menstruele cyclus meer hebben ("postmenopauzale vrouwen") een grotere kans hebben op het ontwilkkelen van osteoporose het "pioreus worden wan de botten". Poreuze botten zijn het gevolg van een verminderde productie van het harmoon oestrogeen, dat inviloed uitoefent op de botopbouw.

De gevolgen van de menopauze kunnen het beste worden behandeld door toediening van oestrogenen. Deze therapie is echter niet altijd geschikt wanwege de bijwerkingen die kumnen optreden. Daarom is men de laatste paar jaren op zoek gegaan naar nieuwe, niet hormonale behandelingsmethoden, om botverlies na de menopauze te voorkomen.

$\mathrm{X}$, en stof die behoort tot de bisfosfonaten, is een wan deze nieurwe producten, ontwikkeld door firma $\mathrm{A}$. $\mathrm{X}$ remt een wersnelde botomzetting bij verscheidene ziektebeelden en heeft een positief effect op de verhouding tussen botopbouw en botafbraak:

Tot nu toe zijn er 1000 patienten behandeld met .X. met een dosis varièrend van $x$-y mg/dagg voor een periade van 2 tot 6 maanden: In deze patièntengroep zjin geen ernstige bijwerkingen geconstateerd. Bijwerkingen die kunnen optreden zijn darmklachten (diarree) en misselijkheid. Deze symptomen verdwijnen echter onmidulelijk wanneer de behandeling wordt gestopt. Bij 1 van de 1000 behandelde patienten is een langer durende overgevoeligheidsreactie van de huid gerapporteerd. Het is daarom raadzaam om uw huisarts direct in te lichten indien u tijdens de studie jeuk of huiduitslag krijgt. Een eerder onderzoek, dat is gedaan bij post-menopauzale vrouwen, heeft aangetoond dat toediening van $X$ gedurende een periode van 6 maanden het botverlies vermindert.

Door uw arts bent u gevraagd om deel te nemen aan een klinisch onderzoek om het resuitaat van de voorafgaande onderzoeken te bevestigen. Het onderzoek is internationaal; zowel in Europa als in de Verenigde Staten zulle patiènten aan dit onderzoek deelnemen. In totaal zullen er 900 patiènten deelnemen aan de $X$ studie-1 en 300 patienten aan de $X$ studie-2.

On na te gaan of $u$ daadwerkelijk een lage botmasa heeft zult $u$ eerst een botdichtheidsonderzoek ondergaan, dit wordt gedaan met een rontgenapparaat waarvan de stralingsbelasting vrijwel onschadelijk is. Indien uit deze screening blijkt dat u naast een lage botdichtheid ook afwijkingen in de structuur van uw rugwervels vertoont, kunt $u$ dewinemen aan $X$ studie-1. Indien u echter alleen een lage botmassa heeft kunt u deelnemen aan de $X$. studie-2

Indien $u$ in aanmerking komt om deel te nemen aan én van beide studies zullt $u$ gedurende twee jaar behandeld. worden met $\mathrm{x} \mathrm{mg} \mathrm{X}$ of met $\mathrm{y}$ mg $\mathrm{X}$ of met een placebo (een niet-actieve stof). Noch u, noch uw behandelend arts zallen op de hoogte zijn of $u$ met $A$ of placebo behandeld wordt. Hiertoe zult $u$ iedere maand gedurende 1 jaar dagelijks extra calcium krijgen.

Tijdens de gehele duur van de studie ( 3 jaar) zult u met behulp van een dieetlijst bij moeten houden wat u eet en drinkt, om na te gaan hoeveel calcium u dagelijks via uw voeding naar binnen krijgt.

Gedurende de 3 jaar van het onderzoek zullen geregeld controles plaatsvinden in de vorm van botdichtheidsmetingen (ieder half jaar). Een keer per jaar zal er een röntgenfoto van uw nug worden gemaakt om te bekijken of er afwijkingen in de structuur van uw nuggenwervels zijn ontstaan of, indien er al afwijkingen waren, om te bekijken of de afwijkingen verergend zijn en of er nieuwe afwijkingen zijn opgetreden. Ieder half jaar zal er tevens urine- en bloedonderzoek plaatsvinden, om de mate van botopbouw en de veiligheid van het medicijn te bepalen.

Het is niet toegestann om te fungeren alls bloeddonor tijdens de duur van het onderzoek. Tevens zult u iedere 3 maandien een routinebezoek aan uw huisarts brengen Het röntgenonderzoek en het botdichtheidsonderzoek zullen in 
en nabijgelegen ziekenhuis plaatsvindien, terwijl het urine- en bloedonderzoek door uw huisarts wordt witgevoerd. Het vervoer van en naar het ziekenhuis zullen woor u geregeld dan wel vergoed wortlen. Ool alle medisehe onderzoekskosten die met de studie verband houden zullen woor $100 \%$ door A worden vergoed. Tevens is A verzekerd voor alle eventuele schades die uit dit onderzoek mochten voortvloeien.

Naast de nadelen die het $\mathrm{X}$ onderzoek met zich meetrengt (botdichtheidsmetingen en röntgenfoto's in het ziekenhuis, bloedafname, slikken van medicijnen, bijhouden wan een dieetlijst en de regelmatige controles bij. uw huisarts) biedt deelname aan éên van beide $Z \mathbf{Z}$ studies ook voordelen: door de regeimatige controles krijgt u een meer intensieve medische begeleiding. Bovendien bestaat de kans dat, bij aanwezigheid van een lage botmassa of fracturen, dat u behandeld wordt met een effectiever geneesmiddel dain de huidige standaardtherapie.

Bij het begin van het onderzoek krijgt u een kaartje, waarop vermeld staat dat u meedoet aan dit onderzoek. Indien u tijdens de studie andere artsen raadpleegt kunt u dit kaartje tonen. Wanneer u tijdens de studie vragen heeft over het onderzoek, uw rechten als deelnemer aan dit onderzoek, of wanneer u meent hiervan nadelige gewolgen te ondervinden dan kum u contact opnemen met dokter (telefoonnummer

Deelname aan dit onderzoek gebeurt geheel op vrijwillige basis. De duur van dit onderzoek is 3 jaar, indien u tijdens dit onderzoek besluit om af te zien van verder deelname, kunt a op elk moment met dit onderzoek stoppen, zonder dat dit consequenties heeft voor uw verdere behandeling. Wel zal uw huisarts uw lichamelijke toestand nog volgen. Ook is het mogelijk dat uw arts redenen ziet om uw deelname aan dit onderzoek te beeindigen en u verder op gangbare wijze te behandelen,

Behalve uw arts zullen ook andere personen die bij het onderzoek betrokken zijn uw medische gegevens inzien. Ook is het mogelijk diat een overheidsinstantie uit de Verenigde Staten, de FDA, bij een controle uw gegevens opuraagt. Alle gegevens zullen strikt vertrouwelijik en anoniem worden werwerkt.

Wanneer er zich in een studie belangrijke ontwikkelingen voordoen die voor u als deelnemer aan deze studie van belang zijn, dan zult u daarvan zo spoedig mogelijk op de hoogte worden gesteld door uw huisarts.

Wanneer $u$ aan het onderzoek deelneemt, volgen hier een paar belangrijke aanwijzingen:

Uw deelname aan het onderzoek wordt zeer op prijs gesteld. Indien u akkoord gaat met deelname, verzoeken wij u die toestemmingsverklaring (het $z g n$ informed consent) te ondertekenen.

\section{Informed consent}

Hierbij verklaar ik dat ik kennis heb genomen van de patienteninformatie behorend bij het $\mathrm{X}$ onderzoek naar het voorkomen van nieuwe wervelfracturen bij postmenopauzale vrouwen. Tevens werklaar ik dat ik alkkoord ga mes deelname aan dit drie jaar durende onderzoek.

Naram patient:

Handtekening:

datum:

Naam arts

Hand tekening:

datum:

centrumnr 
1. Is uw lengte woeger opgemeten?

IANEE

Zo ja: wat was deze volgens a

2. Bent u wegens klachten over uw gezondheid ander behandelling van uw huisarts; specialist of fysiotherapeut?

JA/NEE

$20 \mathrm{ja}$ :

a. walarvoor

b. sinds wanneer

c. bifi wie.

3. Heeft a rugladachten?

IANETE

Zoja

a. voortdurend

JA/NEE

b. met tuissenpozen

JANEE

c. sinds wanneer

4. Bent u bekend met en ziekte ?

(bijv sukerziekts, hart/vaatziekten, bijnierziekte, bijschildklierziekte, epilepsie etc) JAMNEE

Zo ja: met welke riekte( $n$ )

b. sinds wanneer

c. welke medicilmen slikt u daartegen.

5. Heef id andere klachen?

JA/NEF

Zo ja: welke.

6: Gebruikt $u$ andere medicamenten? zoals slaapmiddelen, zenuwtabl, prednison?

Zo ja:

a: wellke.

b: waartegen

c: sinds wanneer

7. Hesft u ooit de pil gebruikt? 20 jathoe lang

8. Heeft u ooit andere hormonen gebruikt? JA/NEE Zo ja:

fi: wathener.

b: hoo llang

c. wartegen.

9. Gebruikt u extra vitaminen of andere inthdelen ter arovilling van voeding?

20 ja welke

10. Heat u ooht iets gebroken?

$20 \mathrm{ja}:$

a: in welk jaar

b: wat.

c: wasdoor.

11. Bent $\mathrm{u}$ wel eens geopereerd? Zo ja:

JANEE

IANNEE a: batarnoeder verwijderd?

MANEE

Zo ja: wammeer:

b. eierstokken verwijderd

JA/NEE

Zo ja: wanneet

én of beide

c. andete operaties?

JA/NEE

Zo ja: wat voor operaties.

Zo ja: wanneer

12. Komt er osteoporose (emstige botontkalking) voor in uw familie?

IA/NEE

Zo ja: bilj wie

13. a: Leeftijd eerste menstruatie .....jaar

b: Leeftijd laatste menstnatie .......jaar

c. Hoeveel zwangerschappen

heeft u doorgemaakt:

d: Heeft w ooit borstvoeding gegeven?

Zo ja: hoe waak

hoe lang.

14. a: Heeft w klachten gehad tijdens of t.g. $v$ de overgang?

JANEE

Zo ja: omschrijf deze

b: Heeft u last gehad van opvliegingen? JA/NEE Zo ja: hoelang

c: Hebben uw moeder, zusters last gehad van opvliegingen?

JA/NEE

Zo ja: wie

15. a: Doet u aan sport?

JA/NEE

Zo ja: welke

hoe valak

hoe lang

b. Deed u vroeger u aan sport?

JA/NEE

Zo ja: welke

hoe vaak

hoe lang.

16. a: Wat woor werk deed u vroeger?

Was dat:licht/matig/zwaars werk

b. Wat voor werk doet u nu?

Is dat licht/matig/zwaar werk

17. Rookt u?

JANNEE

Zo ja: hoe lang a

hoe veel per dag

Zo nee; oort gerookt?

JA/NEE

Zo ja hoe veel per dag .....

hoe veel jaar

wanneer gestopt. 
Exira vragen over de dagelikse woeding:

18. Hoeveel koppen koffie drinkt u per dag... koppen Met melk?

IANEE

19. Hoeveel koppen thee drinkt u per dag... koppen Met melk?
JA/NEE
20.Gehruikt o wel eens alcoholische dranken. JA/NEE

$$
\begin{aligned}
& \text { Zo Ja: welke? } \\
& \text { hoeveel ?..... per dag } \\
& \text {... per week }
\end{aligned}
$$

VRAGEN DIE AAN EEN AANT AL PATIENTEN GESTELD ZIJN:

1:Wat was Uw gewicht toen $U 20-30 \mathrm{jr}$ was ...... kg $3:$ Wat is de kleur van uw ogen?

$2: \mathrm{Zijn}$ Uw eetgewoonten sinds die tijd veranderd?

JA/NEE

Zo ja, wat is er anders dan vroeger?........

\section{VRAGENLUST OVER VOEDING}

Het doel van deze vragenlijst is orn uit te kunnen rekenen hoeveel Calcium u via uw dagelijkse voeding binnen krijgt. Zou $u$ zo vriendelijk willen zijn om deze vragenlijst zo goed mogelijk in te vullen door de juiste antwoorden op te schrijuen of het juiste antwoord te omcirkelen? 
14. feet u regelmatig melk- (of witte) chocolade?

JANEE

Zo ja, hoeveel eet u per week?

aantal repen.

15. Eet u regelmatig puire chocolade?

Zojas hoveell eet u per week? aantal repen.

16. Hoeveel kirasnwater drinkt u per dag? aantal glazen.... aantall liter.

\section{Drinkt u mineraalwater?}

Zo ja, hoeveel? aantal glazen per dag.... aantal liters per dag

18.Drinkt u elke dag wijn, bier, cider of vruchtesap?

JA/NEE

Zo jas hoeveel?

aantal glazen per dag.......... 


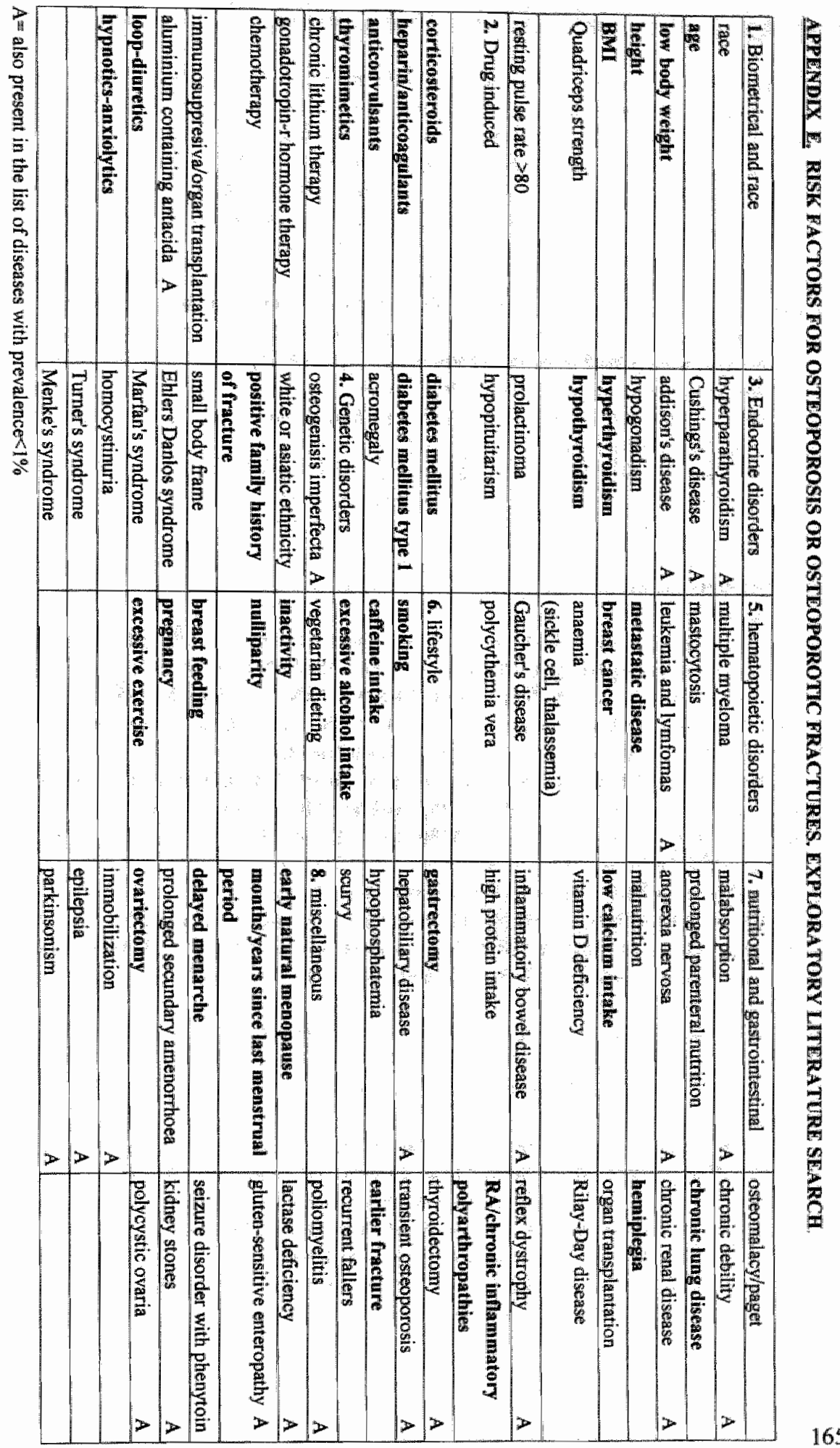




\section{APPENDIX F INCLUSION AND EXCLUSION CRTTERLA.}

\section{Inclusion criteria}

1. Caucasian or onientallysian females.

2. Age between 50 and 80 years.

3. Post-menopausal (natural occurring), defined as last menstrual period at least 12 months prior to study entry or surgically postmmenopausal by documented bilateral ovariectomy performed at least 12 months prior to study entry. Subjects who have undergone a total hysterectomy will also be allowed to enter the study provided that within 6 weeks of study entry their FSH plasma lewel is above 50 i... .

4. Established osteoporosis defined as: at least two "mild" or one "moderate" vertebral deformity, but no more than five vertebral deformities of any severity and without history of significamt trauma. (Subjects with a moderate or severe deformity of vertebrae $\mathrm{L} 2, \mathrm{~L} 3$ or $\mathrm{L} 4$, are not to be entered into the study).

5. Low bone mass in at least 2 assessable lumbar vertebrae $(L 2, L 3, L 4)$ defined as a mean vertebral $B M D$ at least 2 standard deviations below the mean BMD for women 30 years of age, i.e. less than $0.860 \mathrm{~g} / \mathrm{cm} 2$, when measured by dual X-ray densitometry using Hologie Instruments or less than $0.960 \mathrm{~g} / \mathrm{cm} 2$ when measured by dual $X$-ray densitometry using. Lunar instruments.

6. Subjects capable of comprehending the nature of the study and able and willing to comply with the protocol request throughout the three year duration of the study.

7. Signed written informed consent statement.

\section{Exdusion criteria}

1. Black females.

2. Substantial scoliosis, excessive osteophytosis, sufficient lumbar fractures, or spinal fusion (determined by AP lumbar spine X-ray), so as to preclude reasonable measurements of BMD in the spine.

3. Previous treatment with any bisphosphonate or sodium fluoride preparation during the year prior to study entry, unless such treatment was more than 6 months prior to the study entry and the duration of treatment was less than 15 days for a bisphosphonate or 30 days for sodiumfluoride.

4. Treatment with estrogens (except vaginal estrogens administered up to two times per week are allowed), glucocorticoids (except localized topical steroid application is allowed), androgens $s_{n}$ anabolic steroids, phosphate or pharmacological doses of calcium (more than $2000 \mathrm{mg}$ daily) or vitamin D (more than $1000 \mathrm{IU}$ daily) during

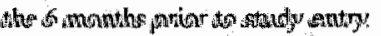

5. Treatment with calcitonin during the 2 months prior to study entry.

6. Significant deviation from normal in either the physical examination or laboratory tests, as evaluated by the clinical investiggator. A significant deviation will include, among other things, clinically relevant cardiovascular (including acute myocardial infarction or stroke within 6 months of entry), renal (including evidence of decreased renal function),

endocrinologie (including thyroid disease unless the subject is biologically euthyroid), neurologic (including epilepsy) or clinically significant rhesmatologic (including rheurnatoid arthritis) disesse. In the case of a breast malignancy, the subject will be eligible if she has been in remission for 5 years, without any treatment. Other malignancies will be excluded.

7. Secondary osteoporosis, as suggested by chronic use of drugs known to cause osteoporosis, including glucocorticoids, anticonvulsant therapy (phenobarbital and diphenylhydantoin), phosphate-binding antacids, lithium, cytotoxic agents, and heparin anticoagulants. Thyroid hormone preparations are permissible if the dose regimen has been stable for at least 2 months and ultrasensitive ISH levels are normal. Thiazide diuretics are permissible if the dose regimen has been stable for at least 3 months.

8. Secondary osteoporosis, as suggested by any of the following: glucocorticoid excess (endogenous or exogenous), immobilization, hyperparathyroidism, gastrectomy, malnutrition, malabsorption syndromes, renal 
osteodystrophy, anorexcia nerwosa, chronic obstructive lung disease, malignancy, chemotherapy, and Paget's disease of the bone.

9. Need for chromic use of concomitant medication during the study period that may affect bone calcium metabolism, including androgens, estrogens (except vaginal strogens administered up to two times per week are allowed), bisphophonates (other than study drug), calcitonins, glucocorticoid drugs (except localized topical steroid application is allowed), anticonvulsant therapy (phenobarbital and diphenylhydantoin), phosphatebinding antacids, lithium, cytotoxic agents, and heparin anticoagulants (more than 2 months).

10. Lower extremity long bone fracture or bone fracture or bone surgery during the 2 months prior to study entry.

11. History of drug abuse or chromic alcoholism during the 12 months prior to study entry.

12. History of severe drug-related allergy, including any bisphosphonate or sulfa allergy or history of anaphylaxis

13. Participation in an investigational drug study during the 30 days prior to study entry.

\section{APPENDIX G.}

OVERVIEW OF ALL INDEPENDENT VARIABLES USED IN THE REGRESSION ANALYSIS.

\begin{tabular}{|c|c|c|c|c|}
\hline $\begin{array}{l}\text { Age, } \\
\text { over } 60 \text { years * }\end{array}$ & $\begin{array}{l}\text { Fractures during the } \\
\text { past } 5 \text { years ** }\end{array}$ & $\begin{array}{l}\text { Menopause before } \\
\text { the age of } 45^{*}\end{array}$ & Alcohol intake & Sports in the past \\
\hline $\begin{array}{l}\text { Weight, } \\
\text { under } 70 \mathrm{~kg} *\end{array}$ & Presence of disease & $\begin{array}{l}\text { Less than } 35 * \text { fertile } \\
\text { years }\end{array}$ & Smoking & $\begin{array}{l}\text { Sporting activities with } \\
\text { axial pressure, at present }\end{array}$ \\
\hline $\begin{array}{l}\text { Height, } \\
\text { under } 160 \mathrm{~cm}^{*}\end{array}$ & $\begin{array}{l}\text { Use of the pill for } \\
\text { more than } 5 \text { years ** }\end{array}$ & Number of children & $\begin{array}{l}\text { Calcium intake, } \\
\text { less than } 500 \mathrm{mg}\end{array}$ & $\begin{array}{l}\text { Sporting activities with } \\
\text { axial pressure, in the past }\end{array}$ \\
\hline $\begin{array}{l}\text { BMI, } \\
\text { under } 27 \mathrm{~kg} / \mathrm{m}^{2} \\
\text { * }\end{array}$ & $\begin{array}{l}\text { Use of hormones for } \\
\text { more than } 5 \text { years ** }\end{array}$ & $\begin{array}{l}\text { Perimenopausal } \\
\text { complaints in history }\end{array}$ & $\begin{array}{l}\text { Occupational } \\
\text { exercise in the past, } \\
\text { moderate }\end{array}$ & $\begin{array}{l}\text { Sporting activities with } \\
\text { axial pressure, at present } x \\
\text { sporting activities with } \\
\text { axial pressure, in the past }\end{array}$ \\
\hline $\begin{array}{l}\text { Currently under } \\
\text { treatment by GP } \\
\text { or specialist }\end{array}$ & $\begin{array}{l}\text { Ovariectomy } \\
\text { in history }\end{array}$ & $\begin{array}{l}\text { Positive } \\
\text { family history of } \\
\text { osteoporosis }\end{array}$ & $\begin{array}{l}\text { Occupational } \\
\text { exercise in the past, } \\
\text { heavy }\end{array}$ & $\begin{array}{l}\text { Occupational exercise } \\
\text { with axial pressure }\end{array}$ \\
\hline $\begin{array}{l}\text { Presence of } \\
\text { low back pain }\end{array}$ & $\begin{array}{l}\text { Hysterectomy } \\
\text { in history }\end{array}$ & Coffee intake & $\begin{array}{l}\text { Sporting activities at } \\
\text { present }\end{array}$ & $\begin{array}{l}\text { Education level } \\
1-2 \text { versis } 3-7\end{array}$ \\
\hline
\end{tabular}

* Chosen cut-points all very close to the maximum of the sums of sensitivities and specificities in the receiver operating curve (ROC) analysies. ** 5-year cut-points: calculated optimum. 